\title{
Chattanooga Shale
}

and Related Rocks

of Central Tennessee

and Nearby Areas

GEOLOGICAL SURVEY PROFESSIONAL PAPER 357

This report concerns work done on behalf

of the U.S. Atomic Energy Commission

and is published with the permission of

the Commission

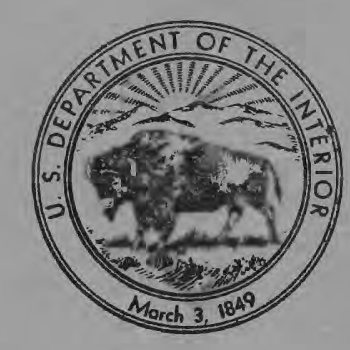




\section{Chattanooga Shale}

and Related Rocks

of Central Tennessee

and Nearby Areas

By LOUIS C. CONANT and VERNON E. SWANSON

GEOLOGICAL SURVEY PROFESSIONAL PAPER 357 "It is the geologist's plane of reference, as well as puzzle" Safford (I869).

This report concerns work done on behalf

of the U.S. Atomic Energy Commission

and is published with the permission of

the Commission

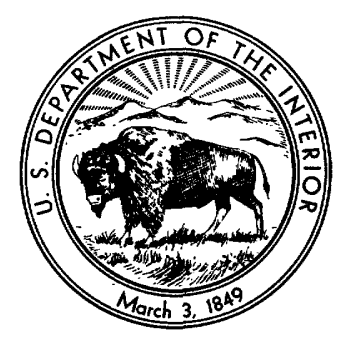

UNITED STATES GOVERNMENT PRINTING OFFICE, WASHINGTON : 1961 


\section{UNITED STATES DEPARTMENT OF THE INTERIOR}

STEWART L. UDALL Secretary

GEOLOGICAL SURVEY

Thomas B. Nolan, Director

The U.S. Geological Survey has cataloged this publication as follows:

\section{Conant, Louis Cowles, 1902-}

Chattanooga shale and related rocks of central Tennessee and nearby areas, by Louis C. Conant and Vernon E. Swanson. Washington, U.S. Govt. Print. Off., 1961.

v, 91 p. maps, diagrs., tables. $30 \mathrm{~cm}$. (U.S. Geological Survey. Professional paper 357)

Part of illustrative matter in pocket.

Bibliography: p. 85-88.

1. Shale-Tennessee. 2. Geology-Tennessee-Chattanooga area. I. Swanson, Vernon Emanuel, 1922- joint author. II. Title: Chattanooga shale. (Series)

For sale by the Superintendent of Documents, U.S. Government Printing Office Washington 25, D.C. 


\section{CONTENTS}

Abstract

Introduction.

Location and general relations.

Fieldwork

Acknowledgments.

Terminology

Rock terms.

Color terms

Linear measurements

Sample numbering

Surface features

General geology

Regional stratigraphy

Structure.

Regional structure.

Cryptoexplosive (cryptovolcanic) structural features in Tennessee.

Flynn Creek feature

Chattanooga shale..........

History of the name

Pre-Chattanooga surface.

General character

Sub-Chattanooga residuum. . . . . . .

Age

Historical summary

Fossils

Plant matter

Conodonts.

Bones_.........

Other fossils

Present views.

Stratigraphy

Classifications

Suggested standard locality

Basal sandstone............

Hardin sandstone member. . . . . . . . . . . . .

Dowelltown member.

Lithologic character.

Extent and thickness

Lower and upper contacts..........

Lower unit

Upper unit..........

Gassaway member....... Lithologic character....................

Extent and thickness.........................

Lower and upper contacts . . . . . . .

Basis for subdivision. . . . . . . . . . . .

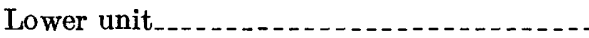

Middle unit_._......

Upper unit

Distribution
Page
1

2

3

4

5

5
Chattanooga shale-Continued Page

Composition. . . . . .

Chemical determinations................ 43

Petrographic determinations............... 43

Quartz_................ 45

Mica

Clay

Feldspar....... 46

Pyrite and marcasite

Phosphate......... 47

Plant matter......... 47

Other constituents ...................... 48

Paleogeography during Late Devonian time........ 48

Regional tectonic influence.................. 48

Geosyncline......................... 51

Landmass

Interior platform .

Extent of the Chattanooga sea $\ldots \ldots \ldots$

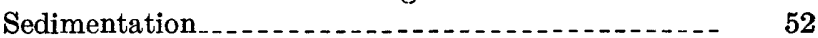

Sources................ 52

Transportation........ 54

Rate of accumulation

Compaction........... 55

Relation of black shale to gray claystone_._._. $\quad 55$

Environment of deposition.................... 56

General considerations........... 56

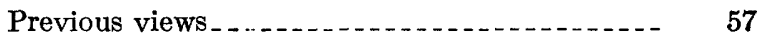
Indications of deep-water origin of the shale... $\quad 59$ Indications of shallow-water origin of the shale $\quad 60$

Maury formation ......... 62

History of the name

Suggested standard locality

General description....... 63

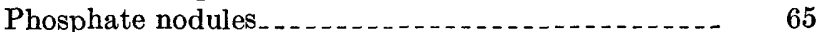

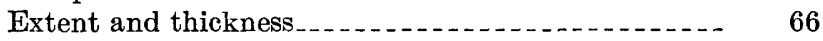

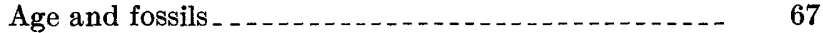

Lower and upper contacts

Significance._._. 68

Economic geology

Light-weight aggregate $\ldots \ldots \ldots \ldots$

Oil shale_._. 69

Phosphate....

Pigment........ 70

Sulfuric acid .

Uranium_._. 70

Sampling

Determination

Relations_._.

Origin and distribution

Regional variations in content_._.

Tonnage............. 76

Locality register.

Selected references. 85

Index 


\section{ILLUSTRATIONS}

[Plates 1, 3, 7, 8, 12, 14, 15, and 17 in pocket]

Plate 1. Outcrops of the Chattanooga shale and of the Maury formation in central Tennessee and nearby areas.

2. Falls of Fall Creek

3. Sub-Chattanooga geologic map of central Tennessee.

4. $A$, Basal part of the Fort Payne chert. $B$, Folded and crumpled beds of the upper (Gassaway) member of the Chattanooga shale on east side of the Sequatchie Valley. $C$, Gentle syncline in the Eastern Highland Rim area. $D$, Dipping beds of Chattanooga shale on sloping side of the Flynn Creek cryptoexplosive feature_- Faces 18

5. $A$, Angular unconformity of about $4^{\circ}$ at base of Chattanooga shale, west of Nashville, Tenn. $B$, Sub-Chattanooga residuum near Pulaski, Giles County, Tenn. C, Photomicrograph of a Tasmanites spore in gray claystone of the upper unit of the Dowelltown member of the Chattanooga shale................. Follows 18

6. A, Massive black shale of the Gassaway member overhanging shale of the Dowelltown member. $B$, Characteristic outcrop of the Chattanooga shale in De Kalb County, Tenn.

7. Fence diagram showing relations of the several units of the Chattanooga shale and of the Maury formation.

8. Thickness of the Dowelltown member of the Chattanooga shale.

9. $A$, Massive shale of the Gassaway member overhanging the weaker beds of the upper unit of the Dowelltown member. $B$, Gray claystone and black shale beds of the upper unit of the Dowelltown member. $C$, Center Hill bentonite bed in upper unit of the Dowelltown member. $D$, Minute laminae of siltstone in sawed block of massive black shale of the Gassaway member

10. A, Massive black shale of the Gassaway member in contrast with the friable shale of the Dowelltown member. $B$, Typical outcrop of weathered Chattanooga shale in road cut.

11. $A, B$, Photomicrographs of black shale of the upper unit of the Gassaway member showing regularity of the lamination. Follows 34

12. Thickness of the Gassaway member of the Chattanooga shale.

13. A, "Varved" bed at base of middle unit of the Gassaway member. B, Maury formation between the Fort Payne chert and the Chattanooga shale. C, Maury formation.

14. Approximate regional distribution of Upper Devonian and Lower Mississippian black shale and related rocks in the United States.

15. Thickness of the Chattanooga shale, exclusive of the Hardin sandstone member.

16. $A$, Standard section of the Maury formation. $B$, Phosphate nodule bed at base of the Maury formation. $C$, Contact between Fort Payne chert and Maury formation.

17. Graphs showing oil yield of the Chattanooga shale.

Figure 1. Index map of area in which the Chattanooga shale and the Maury formation were studied in detail...........

2. Chief physiographic features of central Tennessee and nearby areas .

3. Cross section of the Flynn Creek cryptoexplosive feature

4. Map and cross section of the Swan Creek area of Tennessee showing the gradual thickening of the black shale unit of the Chattanooga shale seaward from a large island.

5. Standard section of the Chattanooga shale.

6. Thickness and distribution of the Hardin sandstone member

7. Map showing distribution of the Center Hill bentonite bed in central Tennessee.

8. Map of outcrops that show the thinning of the upper unit of the Dowelltown member.

9. Cross section along an east-west line of diamond-drill holes that passes 2 miles south of Smithville, Tenn.....-

10. Cross section along an east-west line of diamond-drill holes that passes 3 miles south of Smithville...........

11. Correlation of units of the Chattanooga shale in northern Tennessee and southern Kentucky .

12. Block diagram showing generalized interpretation of Late Devonian paleogeography and the stratigraphic relations of the sediments.

13. Map outlining paleotectonic and paleogeographic features in the United States near the end of the Devonian

14. Chart showing standard section of the Maury formation

15. Apparent interfingering of the Maury formation and the Chattanooga shale

16. Localities of drill holes in Chattanooga shale

17. Localities of drill holes near Smithville, Tenn

18. Gamma-ray log of the Chattanooga shale and the Maury formation. 
TABLES

TABLE 1. System for numbering stratigraphic samples.

2. Comparison of stratigraphic nomenclature and age assignments of Campbell and of this report.....

Page

3. Thickness data on the Dowelltown member, eastern edge of the Nashville Basin

4. Thicknesses of units at selected outcrops where the Bransford sandstone bed is present......

5. Chemical analyses of outcrop samples of Chattanooga shale in Tennessee

6. Chemical composition of shales and graywackes

7. Mineralogic composition of the more uraniferous parts of the black shale

8. Clay content of Chattanooga shale.

9. Analysis of vitrain from the Chattanooga shale

10. Phosphate content of nodules from the Chattanooga shale and the Maury formation

11. Average thickness and uranium content of the lithologic units of the Chattanooga shale on the Eastern Highland Rim, between DeKalb and Coffee Counties, Tenn

12. Thickness and uranium content of samples of the Gassaway member from the more eastern drill holes compared with the average from holes on the Eastern Highland Rim.

13. Localities of outcrops shown on maps accompanying this report

14. Correlation of locality numbers 


\title{
CHATTANOOGA SHALE AND RELATED ROCKS OF GENTRAL TENNESSEE AND NEARBY AREAS
}

\author{
By Loujs C. Conant and Vernon E. Swanson
}

\section{ABSTRACT}

The Chattanooga shale and Maury formation, which have a combined thickness of about 35 feet, crop out on the steep slope between the Nashville Basin and the surrounding Highland Rim; outside the basin they are exposed in several river valleys and in folded areas. Throughout most of the area studied these rocks are nearly flat lying, but in the southeastern part they have been involved in the Appalachian folding and are commonly contorted and sheared.

The Chattanooga shale, now considered to be of Late Devonian age, lies unconformably on many formations ranging in age from Middle Ordovician to Middle Devonian. It is overlain, with probable local disconformity, by the Maury formation, chiefly of Mississippian age, which is overlain conformably by the Fort Payne chert and related rocks. Hass' studies of the conodonts established the ages of the Chattanooga and the Maury, and other studies of bones and plant remains have verified his findings concerning the age of the Chattanooga.

The following stratigraphic classification is used in this report:

Maury formation.

Chattanooga shale:

Gassaway member :

Upper, middle, and lower units recognized; locally the Bransford sandstone bed is at the base.

Dowelltown member:

Upper and lower units recognized; the Center Hill bentonite bed is in the upper unit.

Hardin sandstone member (present locally only).

Standard localities in DeKalb and Williamson Counties, Tenn., for the Chattanooga shale and the Maury formation, respectively, are proposed.

The Hardin sandstone member is a quartzitic, slightly phosphatic, virtually unfossiliferous unit present only in the southwestern part of the area studied. In a complete section the Hardin grades upward into black shale of the Dowelltown member, but locally it is overlain abruptly by black shale of the Gassaway member, and in a few places by the Maury formation. These relations suggest a short erosion interval at the end of Dowelltown time and either a local absence of sedimentation during Gassaway time or another interval of local erosion after Gassaway time.

A thin sandstone that is present nearly everywhere at the base of the Chattanooga shale has commonly been called the Hardin sandstone, but such usage is unwarranted as the sandstone is quite unlike the Hardin in both lithologic character and age. The basal sandstone of the Chattanooga, commonly an inch or less thick, ranges in age from earliest Late Devonian to earliest Mississippian, depending on the time that the sea first inundated an area. In the Swan Creek phosphate area the "blue phosphate" is an unusually thick and phosphatic manifestation of the basal sandstone of late Chattanooga and probably even of early Maury age.
The Dowelltown member has a pronounced two-fold division east of the Nashville Basin: the lower unit is chiefly black shale, the upper unit is alternating gray claystone and black shale. The lower shale unit commonly has a less massive appearance than the shale of the Gassaway member. Black shale lies immediately above the basal sandstone, locally is interbedded with the sandstone, or in some places lies directly on the pre-Chattanooga rocks. The shale unit locally has many thin beds or films of fine sandstone.

The upper unit of the Dowelltown, because of its abundant beds of gray claystone, is the most easily recognized subdivision of the Chattanooga shale. Near the top is the distinctive Center Hill bentonite bed, about 1 inch thick, that can be traced over a wide area in east-central Tennessee. The gray beds probably represent times when the stagnant sea was aerated sufficiently to partially oxidize the organic matter over wide areas, whereas the black shale results from reducing conditions in which sulfurous bottom water prevented oxidation of the organic matter. The cause of these postulated aerations is unknown. Toward the north the gray claystone beds diminish in number, the lowest beds disappearing first. No unconformity separates the lower and upper units of the Dowelltown, so the lowest gray beds are probably less widespread because the hypothetical supposed aerating agency did not at flrst extend as far northward as it did later. A slight diastem seems to separate the Dowelltown from the overlying Gassaway member, at least locally.

The Dowelltown member is absent over much of the area west of the Nashville Basin. Where it is present in that area, the two lithologic subdivisions cannot be identified and the Dowelltown is a nearly massive unit of dark-gray shale having a thin basal sandstone. The member is also not a recognizable lithologic unit south of Tennessee.

In part of the area the Gassaway member can be divided into three units because of the presence of an inconspicuous middle unit that contains a few thin beds of distinctive gray siltstone and claystone. A sandstone at the base of the Gassaway along the Northern Highland Rim is termed the Bransford sandstone bed, an adaptation of usage by Campbell (1946). A unique "varved" bed marks the base of the middle unit but probably does not represent annual layering. Except for the thin middle unit, the entire Gassaway is a nearly homogeneous succession of extremely thin bedded and tough black shale that, when unweathered, has a massive appearance. In the northern part of the area the upper unit of the member is thicker and in its upper part consists of a phosphate nodule-bearing shale that is younger than the upper part of the shale elsewhere.

The Chattanooga shale is part of a blanket of black shale and other marine rocks that were deposited in a sea that covered large parts of North America in Late Devonian time. In Tennessee this sea covered most of what is now the Nashville dome, but a few areas appear to have been islands during Chattanooga time.

The black shale contains about 20 to 25 percent quartz, 25 to 
30 percent clay and mica, 10 percent feldspar, 10 to 15 percent pyrite, 15 to 20 percent organic matter, and 5 percent miscellaneous constituents. Most of the quartz grains range in size from that of clay to about $0.02 \mathrm{~mm}$ in greatest diameter. The black shale is minutely and well laminated, and this lamination causes the fissility of the rock upon weathering.

The gray claystone has, by contrast, a somewhat larger proportion of clay minerals, finer grained quartz and mica, only scattered fine particles of organic matter and pyrite, and much coarser stratification.

A shallow-water origin for the Chattanooga shale is indicated by several circumstances. By contrast, any deep-water hypothesis involves serious inconsistencies. The black mud that formed the Chattanooga shale probably accumulated in water 100 feet deep or less; some apparently accumulated close to shorelines in water only a few feet deep. The sediment is believed to have been transported by sea-bottom traction, by suspension, and by wind. The water-borne part probably came from land areas far to the east and northeast and from island and other land areas in and near central Tennessee. Sedimentation appears to have been phenomenally slow, 30 feet of shale representing deposition during most of Late Devonian time.

Repeated gentle agitation of the water by waves and currents probably shifted the mud continuously, so that it was well sorted and was spread smoothly over the bottom. The fine laminations, which are typically irregular and discontinuous, are thought to result from this repeated reworking of the sediments over a long period of time. No varves representing annual or other regular cycles of deposition were recognized. Locally the mud was slightly channeled, and in at least one area more than a foot of sediment was stripped away by submarine planation.

The Flynn Creek cryptoexplosive structure, a small area of highly disturbed Ordovician rocks, is of especial interest because an abnormal thickness of some 200 feet of Chattanooga shale is present above the structure. Apparently a deep depression did not exist over this disturbed area at the beginning of Chattanooga time, as supposed, but the area sank slowly as the black mud accumulated; the subsiding basin was kept filled by black mud that moved along the sea bottom for considerable distances.

The Maury formation consists chiefly of green mudstone or glauconitic sandstone and in most places has a conspicuous bed of phosphate nodules at or near its base. In some areas black shale is also present in the formation. The Maury is commonly only about 1 to 4 feet thick and represents most of Kinderhook (Early Mississippian) time. Its lower contact is fairly distinct at most places; its upper contact is commonly abrupt where overlain by the Fort Payne chert but is gradational where overlain by the New Providence shale and its equivalents. In spite of its well-defined contacts, little physical evidence has been seen of any unconformity associated with the Maury. The formation seems to represent a time of transition between the shallow black-mud sea of Late Devonian time, and the more widespread, well-aerated, and presumably deeper sea of Mississippian time.

The phosphate nodules are present chiefly as irregularly shaped nodules, balls, and plates, most of which are concentrated in a single layer and are embedded in black shale, glauconitic sandstone, or claystone. The bed of nodules is a distinctive feature of the Maury formation over most of the area and is known to range in thickness from 1 inch to 2 feet within a horizontal distance of 50 feet. The nodules seem to have accumulated at a time when clastic sedimentation had almost ceased, as they appear to be doing in places on the ocean floor today.

Economically the rocks of the Chattanooga shale and Maury formation have thus far been of little importance. There are several possibilities for future utilization of the rocks, especially if the possible by-products are considered. The oil yield of the shale is about 10 gallons per ton, but this is much below the yield of shales currently considered for oil extraction. Other possible products that might be obtained are phosphate, black pigment, sulfuric acid, uranium, and light-weight aggregate for concrete.

Each of the five stratigraphic units of the shale has a different uranium content, which varies only slightly over large areas, but the three units of the Gassaway member are consistently the richest. For about 50 miles along the Eastern Highland Rim, from DeKalb County to Coffee County, shale approximately 15 feet thick contains an average of about 0.006 percent uranium, equivalent to about 1,800 tons of metallic uranium per square mile. The grade normally decreases where the thickness increases greatly or wherever the shale contains phosphate nodules. The grade decreases northward into Kentucky, westward along the Northern Highland Rim, and southward into Alabama. Information from widely scattered places suggests that the grade increases slightly eastward toward the Sequatchie anticline where the uranium content appears to be slightly higher.

The uranium is thought to have been removed from the sea water by plant particles on the sea bottom and the relative richness to have resulted from the extremely slow sedimentation.

\section{INTRODUCTION}

The unusual properties of the black Chattanooga shale have attracted the interest of geologists and laymen for fully 100 years, and both groups have studied it in their diverse ways. The geologists, who have disagreed on the age, correlation, and origin of the rocks, became embroiled in the well-known black shale controversy; the farmers and prospectors, lured by its pyrite, coal-black color, and combustibility, have spent untold effort and money trying to exploit its supposed mineral wealth.

The present investigation has shown that the Chattanooga shale is largely or entirely of Late Devonian age and the Maury ${ }^{1}$ formation of Early Mississippian (Kinderhook) age (Hass, 1956).

Some of the most picturesque and succinct statements concerning the black shale in Tennessee were published nearly a century ago by Safford (1869) in his "Geology of Tennessee". Thus (p. 329) :

Although comparatively very thin it is, on several accounts, one of the most interesting formations in the State. It is wonderfully persistent, appearing in place, with rare exceptions, wherever its horizon is presented at the surface. $* * *$ It is the geologist's plane of reference, as well as puzzle, the would-

\footnotetext{
1 The county in Tennessee from which the formation is named is pronounced "Murray," and geologists in the region use that pronunciation for the rock unit.
} 


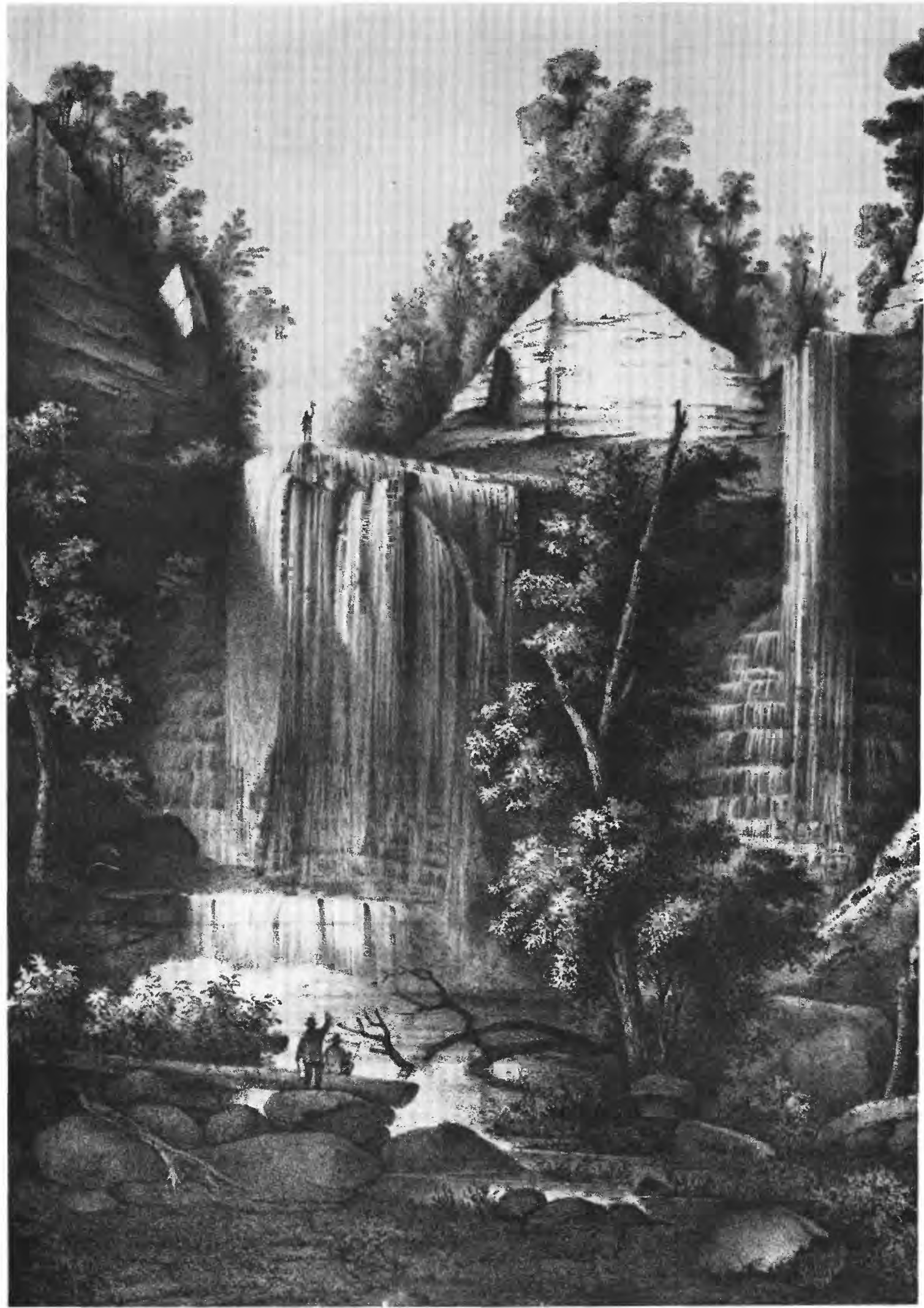

FALLS OF FALL CREEK

One of the typical Highland Rim waterfalls over the Chattanooga shale. Crest of the main fall is formed by the basal 2 feet of the Fort Payne chert. The Chattanooga shale extends downward to about the top of the dome-shaped cascade of the smaller fall at the right. Fort Payne chert is in the upper part of the walls, limestone of Ordovician age in the lower part. Near locality 90. Reproduced from Safford (1869). 

be coal digger's ignis fatuus, a source of mineral waters, the alum and copperas maker's stock, an oil-schist and a pyroschist.

In his description of the shale, Safford (1869, p. 329) gave the following account of one of its well-known characteristics:

The presence of bituminous matter is also characteristic. The shale generally contains so much of this as to be readily ignited, and to burn for a while with considerable energy when in large heaps, or when fragments of it are thrown upon glowing coals. For this reason it is sometimes called a pyroschist. It does not, however, like stone coal, burn to ashes. The bulk, after burning, is the same as before, there being little else consumed beside a small percentage of bituminous matter. It loses, however, its color, by the process, the mass becoming reddish gray. It is often taken as an indication of stone coal, and, in Tennessee, thousands of dollars, and a vast deal of enterprise, have been wasted, in drifting into it.

The possibility of distilling oil from the black shales has long been known (for example, Safford, 1869, p. 329) and has prompted several studies of the Chattanooga shale and its correlatives in the eastern United States. These investigations indicated that the eastern black shales will yield at most about 15 to 20 gallons of oil per ton (Crouse, 1925, p. 62; Miser, 1921, p. 147), which is much less than the yield of black shales in some other areas. Our investigations showed that the average oil yield of the richer upper half of the Chattanooga shale along the eastern edge of the Nashville Basin is closer to 10 gallons per ton.

During the 1940's black shale in various parts of the world was found to be notably radioactive (Russell, 1944, 1945; Beers and Goodman, 1944; Beers, 1945; McKelvey and Nelson, 1950) and to be a potential source of large quantities of uranium. Because the Chattanooga shale, having about 0.004 to 0.008 percent uranium, is one of the more radioactive shales in the United States, the investigations reported here were conducted by the U. S. Geological Survey at the request and with the support of the Atomic Energy Commission. The chief aims were to make a thorough geologic study of the shale and to obtain sufficient information concerning the quantity and distribution of the uranium to evaluate the shale as a potential source of uranium.

This report presents information on the stratigraphy, composition, structure, paleogeography, and origin of the Chattanooga shale in central Tennessee and nearby areas and describes its relationship to the underlying and overlying formations.

\section{LOCATION AND GENERAL RELATIONS}

In Tennessee the Chattanooga shale crops out on the steep slope between the Nashville Basin and the surrounding Highland Rim, and on many high hills with-

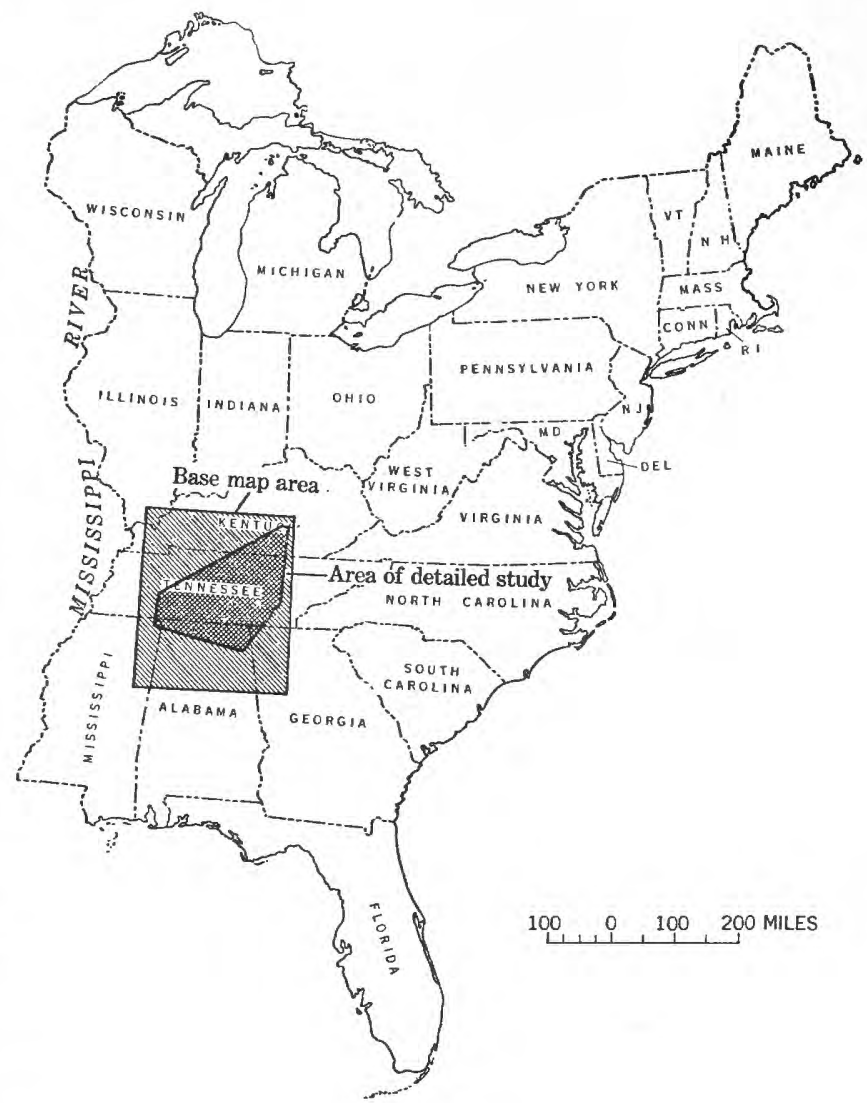

Figure 1.-Index map of area in which the Chattanooga shale and Maury formation were studied in detall.

in the basin. Outside the basin the black shale sequence is exposed in several river valleys and around the large Lexington Basin of Kentucky, Ohio, and Indiana. It also crops out along the ridges and valleys of the folded Appalachians in Tennessee, Georgia, and Alabama. Figure 1 shows the general area of these studies.

Most of the outcrops examined in this study are in or near the Nashville Basin. Initially studies were made on the eastern edge of the Nashville Basin, where the Caney Fork has cut a deep re-entrant into the Eastern Highland Rim, where road cuts and waterfalls afford many excellent exposures of the Chattanooga shale, and where previous reconnaissance studies had indicated the Chattanooga might have its highest concentration of uranium. From the Caney Fork area the investigations were extended northward and southward and then around the entire basin; they included many of the outliers within the basin. Other areas of investigation in Tennessee were the Sequatchie Valley, which is some 50 miles east of the Nashville Basin, and the western valley of the Tennessee River and its eastern tributaries. To the south, scattered outcrops were studied in northeastern Mississippi, northern Alabama, and northwestern Georgia. To the north, the shale was 
studied and sampled in Kentucky in the valleys of the Green and Cumberland Rivers, including the area now inundated by the Wolf Creek Reservoir.

Other field observations in northern Kentucky, Indiana, Ohio, southwestern Virginia, and eastern Tennessee have supplied background information of aid in interpreting the geology of the main area of study.

\section{FIELDWORK}

Field investigations of the uranium in the Chattanooga shale were started by the Geological Survey for the Manhattan Engineer District and were continued for its successor, the Atomic Energy Commission. In June 1944, A. L. Slaughter, S. E. Clabaugh, and W. H. Hass began a reconnaissance survey of the Devonian and Lower Mississippian black shales of the eastern United States and found indications that the uranium content of the Chattanooga shale is higher along the northern part of the Eastern Highland Rim than at most other places. Additional reconnaissance investigations in the eastern black shale areas by J. M. Nelson, K. G. Brill, and A. P. Butler, Jr., consisted chiefly of determining radioactivity and collecting samples for uranium assays. In the course of his work on conodonts Hass also studied the Chattanooga shale and the correlative rocks of several other parts of the eastern United States.

Fieldwork on the present project was started late in 1947 at the request of the Atomic Energy Commission and was continued intermittently until 1955. For much of the first year the chief effort was an intensive sampling program supplemented by a general geologic study. Much of the later work was more largely of a geologic nature, but from time to time sampling programs were part of the study. In all, about 3,000 samples were taken from uranium analyses from about 250 outcrops, from about 75 drill cores, and from a 100 foot adit (pl. 1, loc. 79). Geologic observations were made on many other outcrops and on samples from many exploratory oil wells. Plate 1 shows the outcrop of the Chattanooga shale and about 250 numbered localities from which most of the information used in this report was obtained. Many drill hole locations are shown in figures 16 and 17.

Wherever samples were taken, measurements were made of the several lithologic subdivisions of the Chattanooga shale (table 1, p. 6). In a few places, detailed measurements were made of all obvious lithologic units that are 0.01 foot or more thick and of some beds that are even thinner; for each measured bed the color, fissility, and visible mineralogic characteristics were noted. We also made observations concerning sedimentary structural features and types of contacts that bound the formation and are within it. These detailed observations permitted careful tracing throughout large areas of some units heretofore unrecognized, and revealed details that later helped explain the origin of the shale. The Maury formation, which overlies the Chattanooga shale throughout the area and has often been considered a part of the shale, was studied in a similar manner.

Samples were commonly taken at localities about 1 to 5 miles apart in the belief that they would reveal any significant regional differences in uranium content, but a few were taken at much closer spacing to test for possible short-distance differences.

Hass studied the conodonts in about 325 samples from 65 localities; he was the first worker to acquire information adequate for determining the geologic age of the black shale and related beds and for correlating the lithologic units within the shale from one region to another and from State to State. Detailed results of Hass' studies are presented in a separate report (1956).

Throughout its duration Conant was in general charge of the fieldwork for this project or was closely associated with it. Swanson joined the project in 1949 and conducted most of the investigations along the Northern and Western Highland Rims and in the more western areas in Tennessee.

Andrew Brown supervised a 1948 drilling program and the driving of a 100-foot adit; he also had general charge of much of the sampling from 1947 to 1949 . He made many observations on the geology and later helped materially in compiling data and assembling geologic information.

R. C. Robeck studied the stratigraphy, mapped, and supervised the sampling in several areas from 1947 to 1949. These areas included the Sequatchie Valley of Tennessee, that part of the eastern edge of the Nashville Basin from Cannon to Franklin Counties, much of Jackson and Clay Counties, that part of the Cumberland River valley of Kentucky now inundated by the Wolf Creek Reservoir, and other scattered areas in Tennessee and Kentucky.

R. E. Smith, who was with the project in 1947 and 1948, was in charge of much of the early work in Putnam County and the northern part of DeKalb County.

T. M. Kehn, who was with the project from 1952 to 1954 , spent 1953 on a cooperative drilling program conducted by the Geological Survey and Bureau of Mines for the Atomic Energy Commission. He worked on about 60 diamond-drill cores of the Chattanooga shale and on local geologic problems.

Lynn Glover III worked for several months on the 1953 drilling program and later spent about a year and a half studying the Chattanooga shale outcrops in the 
folded area of southeastern Tennessee, northwestern Georgia, and northeastern Alabama.

All the above men who do not share authorship contributed many observations and ideas that aided immeasurably in the formulation of this report, and to them we owe much.

Others who had short assignments in the field, chiefly to help in measuring and sampling outcrops, were Chester E. Baker, Edward C. Berry, Wilfred J. Carr, John R. Houston, John E. Johnston, Charles Katlin, John C. Reed, Jr., Lawrence E. Shirley, Julian Soren, and Leon D. Willman.

\section{ACKNOWLEDGMENTS}

Many people and organizations contributed to this study and it is impossible to name them all or to recall the sources of all information and the origin of all ideas. Several people and organizations, however, are especially deserving of mention.

The financial support by the Division of Raw Materials, Atomic Energy Commission, made the project possible. The cooperation and constant interest shown by technical personnel of that agency contributed much to the study. Especial interest was shown by Messrs. John Ruck and James Barr.

The Nashville District of the Corps of Engineers, U. S. Army, supplied many maps of its reservoirs, gave access to construction areas and drill cores, and permitted much work on land under its custody.

The Tennessee Division of Geology supplied many maps and publications and gave free access to its large file of well records and cuttings. Mr. H. B. Burwell, State Geologist during the early part of these studies, and Mr. H. C. Milhous were generous of their time and information. Mr. H. W. Ferguson and Mr. W. D. Hardeman, who succeeded Mr. Burwell as State Geologists, continued that friendly cooperation.

The Kentucky Geological Survey also supplied many maps and publications. Dr. A. C. McFarlan, the Director, and Mr. D. J. Jones, the State Geologist, followed the work with interest and cooperated whenever requested. Mr. Jones accompanied Robeck for several days in the field to show him outcrops that seemed worthy of investigation.

The Tennessee Valley Authority drove a 100-foot adit near the Sligo bridge, about 7 miles east of Smithville, Tenn., after two invitations had failed to get private contractors to bid on the work. The TVA also permitted access to its New Johnsonville steam plant site when the foundation excavation afforded excellent exposures of the Chattanooga shale.

The Post Office Department supplied the project with working and storage space at Sparta, Tenn.
The Magnolia Petroleum Co. obtained and turned over to the Geological Survey core samples of the Chattanooga shale from its W. H. Patterson 1 cable-tool well at Gruetli, Grundy County, Tenn.

The U.S. Bureau of Mines in 1953 took 71 diamonddrill cores of the Chattanooga shale for the Atomic Energy Commission, enlarged the Sligo adit, and made various engineering studies of the shale. Mr. Robert T. Hickman, in charge of the drilling, and Mr. Paul Russell, in charge of the engineering work, were most cooperative at all times. The drilling supplied excellent cores for study and assay by the U.S. Geological Survey and other organizations.

Several members of a University of Tennessee party that studied the shale for the Division of Research of the Atomic Energy Commission during the later stages of our studies were in the field several times with members of our project. Their presence, especially that of Dr. P. B. Stockdale, Dr. H. J. Klepser, and Mr. Stuart Maher, afforded opportunities for profitable exchanges of information and ideas.

Dr. T. F. Bates, Mr. E. C. Strahl, and other members of the staff at Pennsylvania State University, who studied the mineralogy of the shale for the Atomic Energy Commission, also discussed some aspects of the shale with us.

Members of the U.S. Geological Survey contributed greatly to the project. R. A. Lawrence helped in many special phases of the work; J. M. Schopf made preliminary studies of the plant remains in the shale; Charles Milton advised on several mineralogic problems; W. H. Monroe handled many of the administrative details. These, and J. F. Pepper, took much interest in the work and offered countless suggestions regarding the geology. Mrs. Bernice L. McCraw compiled much of the statistical information and aided in many ways beyond her normal secretarial duties. About 15 other people had part-time or short-time assignments with the project, either in the office or laboratory.

\section{TERMINOLOGY}

Some terms used in this report in describing rocks have such different meanings to different people that they are defined briefly. These definitions are not intended to be any contribution to, or change in, rock terminology; they are given merely to clarify our usage.

\section{ROCK TERMS}

"Shale" denotes a fine-grained, finely laminated rock having pronounced fissility. As used, it is a rock term based on structure, having only indirect reference to grain size and no implication as to mineral composition. Fresh Chattanooga shale is massive and breaks with 
conchoidal fracture, and only after weathering is it fissile.

"Siltstone" and "claystone" differ from shale only in that they are nonfissile fine-grained rocks classified by grain size. Siltstone consists chiefly of grains ranging from 0.062 to $0.004 \mathrm{~mm}$ in diameter that can be seen with an ordinary hand lens of about 10-power magnification; claystone consists chiefly of particles less than $0.004 \mathrm{~mm}$ in diameter that cannot be seen with a hand lens.

"Sandstone" is a rock whose greater part consists of grains that fall within a $0.062-2.0 \mathrm{~mm}$ range of diameter and that are visible to the naked eye. The term has no implication as to mineral composition.

"Carbonaceous" is here used to denote a rock, generally dark colored, containing abundant organic material. According to some classifications, a predominance of humic organic matter is basis for terming a rock carbonaceous, and a predominance of sapropelic matter is a basis for terming it bituminous. The Chattanooga shale is known to contain both types of plant matter, and in the past it has often been termed a bituminous shale, but we are using the term "carbonaceous," which strictly has wider applicability. Because the Chattanooga yields hydrocarbons when heated, it has also been termed an "oil" shale, a "kerogenous" shale, or a "pyrobituminous" shale, each adjective signifying the same quality.

\section{COLOR TERMS}

With the exception of the generalized usage of "black" and "gray," the color terms appearing in this paper are those used in the Rock-Color Chart prepared by the National Research Council. Rock colors were recorded carefully during detailed field studies, but for the sake of general discussion "black" refers to colors ranging from black to dark gray, and "gray" to colors ranging from medium dark gray to medium light gray. Without this modification little of the rock could properly be called black shale.

\section{LINEAR MEASUREMENTS}

Most measurements of outcrops and drill cores were in feet and decimal fractions of a foot, though some thicknesses in this report are in inches. A few measurements of smaller magnitude were in millimeters.

\section{SAMPLE NUMBERING}

For most outcrops, drill holes, and samples, systematic numbers were applied that would aid in recalling the location of the outcrops and would identify the stratigraphic positions from which the samples were obtained. Inasmuch as these field numbers have been used by some other workers in reporting their studies of the shale (for example, Cuttitta, 1953), the system is explained here.

Early areas of investigation were designated by arbitrarily chosen letters, such as LC or R-C, and within those areas the outcrops were numbered-LC-15, R-C2, etc. Later, a coordinate system was used for most localities whereby 15-minute quadrangles were numbered from south to north and lettered from west to east. Within each quadrangle the outcrops were numbered, thus producing such designations as 13M-7. Table 14 gives the correlation between these field numbers and the numbers used in this report (table 13).

For most outcrops and drill cores the individual samples were numbered downward in a decade system to enable ready identification of the stratigraphic units which they represent. That system is set forth in table 1. When combined with the locality numbers already explained, the samples have such numbers as LC-15-12 or $13 \mathrm{M}-7-31$.

\section{TaBLE 1.-System for numbering stratigraphic samples}

[Names in parentheses are informal terminology used in the field]

Stratigraphic unit $\quad$ Allotted

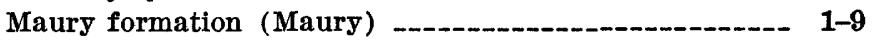

Chattanooga shale:

Gassaway member (upper black shale): Upper unit (top black shale) -.............. 11-19 Middle unit (upper gray siltstone ${ }^{1}$ ) Lower unit (middle black shale) -.-_-_-_-_._- 31-39 Dowelltown member : Upper unit (middle gray siltstone ${ }^{1}$ ) _-_______-_ 41-49 Lower unit (lower black shale) -.-_-_-_-_- 51-59

1 The term "siltstone" was applied at first to these gray beds that are now called claystone.

In nearly all instances only a part of the allotted decade was used. At most places number 11 was reserved for an upper interval of the shale where phosphate nodules were observed, though at some places it was applied to a phosphate-nodule-bearing zone at or near the base of the Maury formation. Locally, where that interval is thick, $11 \mathrm{~A}, 11 \mathrm{~B}$, etc., were used. As the comprehension of the stratigraphy became clearer or where units were misidentified, a few inconsistencies were introduced, but those were relatively minor. At places where the individual units were not obvious, a straight downward succession of numbers was applied to the samples.

\section{SURFACE FEATURES}

The chief physiographic features in the area of most of these investigations are the Nashville Basin, the Highland Rim, the Cumberland Plateau, and the Appalachian Valley and Ridge (fig. 2). 


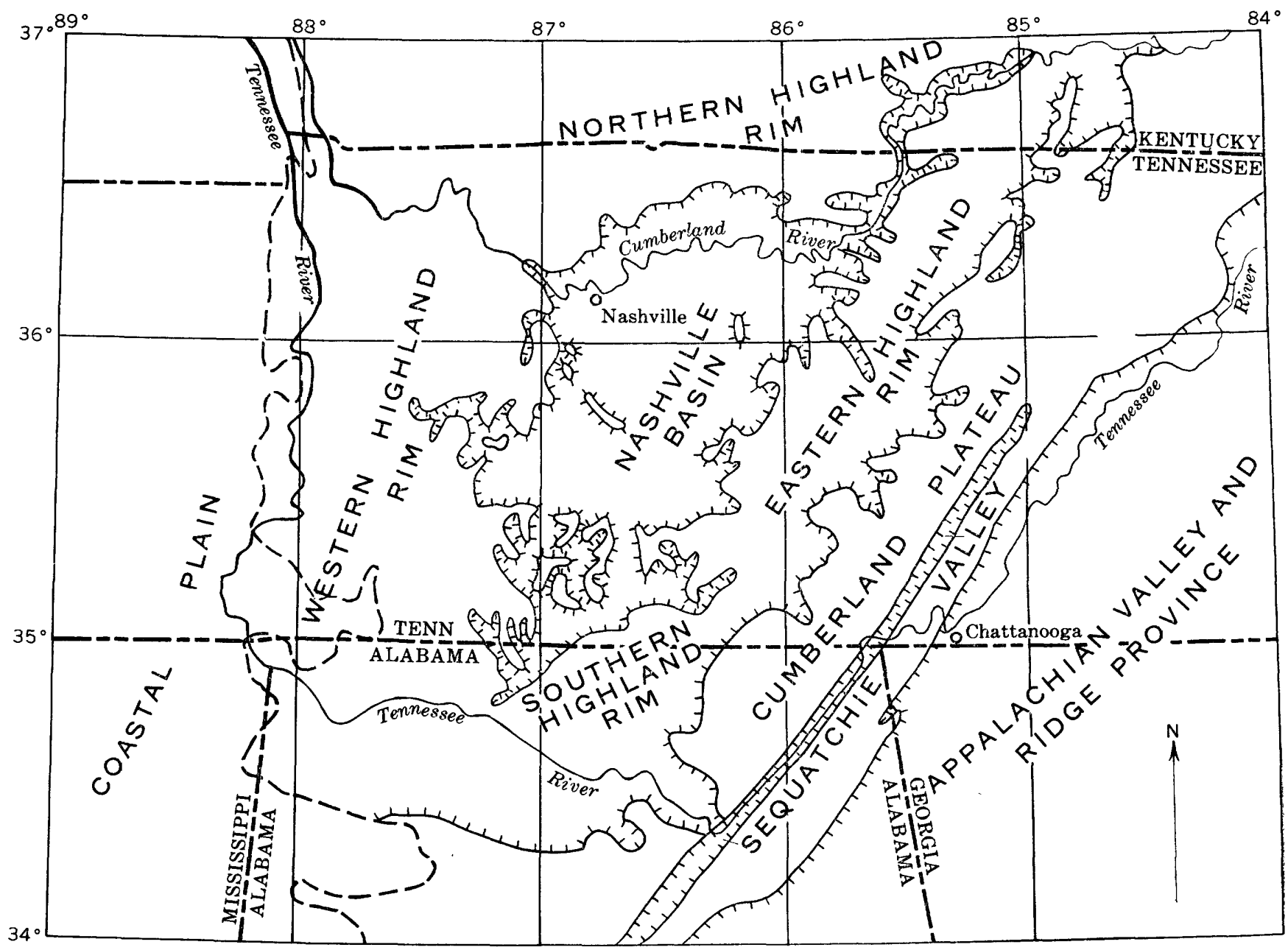

50

0

50 MILES

FIGURE 2.-Chief physiographic features of central Tennessee and nearby areas.

The Nashville Basin, frequently referred to as the Central Basin of Tennessee, coincides with the crest area of the Nashville dome or arch. It has an elliptical outline, is about 120 miles long in a north-northeast direction, and is about 50 miles wide. The floor of the basin is a rolling and hilly limestone lowland about 500 to 700 feet above sea level, surrounded by a more or less flat upland 300 to 500 feet higher than the floor.

The surrounding upland, known as the Highland $\mathrm{Rim}$, is capped at the edge of the basin by rocks that are more resistant to weathering, notably the Fort Payne chert. Most of the high hills that rise from the floor of the basin are capped by the more resistant Highland Rim rocks and are thus outliers of the Highland Rim. Because of their structural position on the Nashville arch, some of these outliers are now 200 to 300 feet higher than the present rim.

Slopes between the Highland Rim and the basin are so steep that rail and highway routes require careful selection and extensive cuts. The Chattanooga shale is well exposed in many of these cuts and in many beautiful waterfalls and gorge walls, some difficult of access. An excellent drawing of one of these waterfalls, printed in Safford (1869, facing p. 83), is reproduced here as plate 2. Concerning this fall and its associated gorge, Safford wrote (p. 83) :

The accompanying plate presents one of these falls, and will serve to show their general features, as they are all very much alike. *** This romantic waterfall is about two miles east of Smithville, in DeKalb County. In addition to the main fall, a cascade, from a greater height, is seen to the right, belonging to a much smaller and different stream. $* * *$ The larger body of water falls ninety-three feet. The gorge below the falls is exceedingly wild and picturesque. Steep slopes rising from the narrow valley are surmounted by precipitous cliffs from one to two hundred feet in height, towering in all, three hundred feet or more above the creek. 
The position of the Chattanooga shale on the steep slopes between the rim and the basin and on the outliers is indicated at most places by a distinct change of slope and vegetation. In general, the upper part of the slopes, which is underlain by the Chattanooga shale and the Fort Payne chert, is too steep for cultivation of crops and so remains wooded. The lower part of the slopes, underlain largely or entirely by Ordovician limestones, is less steep, is commonly cleared, and is planted with corn or tobacco or used for pasture. At most places the position of the Chattanooga shale, just above this change in slope and vegetation, can be easily identified by looking at the hillsides or by examining aerial photographs stereoscopically. Most of the outlying remnants of the rim that are within the basin have steep-sided and well-wooded crests that indicate clearly the parts that are occupied by the Fort Payne chert and the underlying Chattanooga shale.

The Highland Rim is a fairly smooth upland, about 1,000 feet above sea level, that surrounds the Nashville Basin and, in general, slopes slightly away from it. On the rim near the edge of the basin the resistant Fort Payne chert or its equivalent is the surface formation, but farther away successively younger formations of Mississippian age crop out. The different geographic parts of the rim are termed the Northern, the Eastern, the Southern, or the Western Highland Rim, depending on their directions from the basin.

The Eastern Highland Rim has an average width of about 15 to 20 miles and is bounded abruptly on the east by the Cumberland Plateau, which is about 1,000 feet higher. The Northern Highland Rim extends into southern Kentucky and about 100 miles from the Nashville Basin gives way to the Lexington Basin. The Southern Highland Rim merges southward in northern Alabama into the valley of the Tennessee River and beyond that is bounded by a sharp rise to the Cumberland Plateau. The Western Highland Rim, somewhat more dissected, slopes westward, and near the western valley of the Tennessee River passes beneath the Coastal Plain.

The Cumberland Plateau at the latitude of Crossville, Tenn., is about 2,000 feet above sea level but is higher to the north and lower to the south. The eastern edge is marked by the steep Cumberland Front that overlooks the Valley and Ridge province of east Tennessee. The rocks beneath the plateau are nearly flat, but the Sequatchie Valley, a striking feature in part of the area of this study, is a long, narrow, and deep valley trending north-northeast that has been eroded along the axis of a sharp anticline. This valley and its southern extension into Browns Valley of Alabama is 150 miles long, is about equally divided between Tennessee and Alabama, and exposes the Chattanooga shale and older rocks. The ends of the anticline, which have not been breached, form a ridge on the Cumberland Plateau. In Tennessee this ridge is as much as 1,000 feet above the general plateau surface, but at the south end, in Alabama, it is no more than a few hundred feet above the plateau.

The Valley and Ridge province, where the rocks are strongly folded, has strata ranging in age from Cambrian to Pennsylvanian. In this area the relatively incompetent Chattanooga shale has been badly deformed and good exposures are few.

\section{GENERAL GEOLOGY}

\section{REGIONAL STRATIGRAPHY}

All the exposed rocks in the area of this study are sedimentary and range in age from Ordovician to Cretaceous. Local terraces, flood plains, and other surficial deposits of gravel, sand, and clay are of Tertiary and Quaternary age.

Most of the sedimentary rocks originated in widespread seas west of and marginal to the Appalachian geosyncline. Limestone is most abundant, but some sandstone and shale are present. In most places the Chattanooga shale lies on limestones of Ordovician age, but locally it lies on various rocks of Silurian or Devonian age. Wilson (1949, pl. 2) prepared a subChattanooga geologic map (pl. 3) showing the distribution of the formation on the pre-Chattanooga land surface. Widespread gentle folding and local sharp folding (Wilson, 1949, p. 303) was followed by erosion that reduced the land by Late Devonian time to a fairly smooth surface. As a result, the Chattanooga shale, as shown by Wilson's map, lies on 23 different formations.

The Chattanooga shale, though only about 35 feet thick in central Tennessee, probably represents most of Late Devonian time (Hass, 1953; 1956). During our investigations we subdivided the Chattanooga into three members: a basal Hardin sandstone member, which is present only in and near Wayne County, Tennessee; the Dowelltown member; and the Gassaway member. These members are shown in table 2, page 22, and are discussed in detail in a later part of this report. The overlying Maury formation, in most places only 1 to 4 feet thick, is present just above the position of the Chattanooga shale in every adequately exposed outcrop we saw within the area of this report. The Maury is chiefly of Early Mississippian age and the only unit of Kinderhook age in the area of study, but locally the lowest part is of Late Devonian age, and the uppermost part is probably of early Osage age (Hass, 1953; 1956). 
The Fort Payne chert of Early Mississippian (Osage) age consists chiefly of massive bedded chert and cherty limestone as much as 275 feet thick and overlies the Maury formation throughout most of the southern half or two-thirds of the Nashville Basin region, the Sequatchie Valley, and the northern parts of Georgia, Alabama, and Mississippi. The lower 50 to 75 feet of the formation at most places is mainly a resistant succession of chert beds 2 inches to 2 feet thick (pl. 4A). Northward the chert grades laterally into crinoidal reefs and calcareous and noncalcareous claystones that have been variously called the Ridgetop shale, the New Providence formation, and the Greasy Creek facies of the Fort Payne chert (Bassler, 1911; Wilson and Spain, 1936; and Stockdale, 1939). These noncherty beds are the common rocks above the Maury formation in the western valley of the Tennessee River and along the northern and northwestern edges of the Nashville Basin. Green calcareous claystone and crinoidal limestone are also present locally in the lower part of the Fort Payne chert at many places along the eastern edge of the basin (for example, at locs. 16, 39, and 126, pl. 1).

Above the Fort Payne chert is 800 to 1,000 feet of strata, chiefly limestone, of Mississippian age. Still higher, a thick succession of conglomerate, sandstone, shale, and coal of Pennsylvanian age caps the Cumberland Plateau of east-central Tennessee and northern Alabama.

In western Tennessee and adjoining parts of Alabama and Mississippi the Paleozoic rocks are overlain by Coastal Plain sand, gravel, and clay beds of Late Cretaceous age.

\section{STRUCTURE}

\section{REGIONAL STRUCTURE}

The Nashville dome has been a mildly active structural feature since early Paleozoic time. Its repeated uplifts have affected the distribution of several lower Paleozoic formations (Wilson, 1935; 1949, p. 328, 330) and more recently have warped the erosion surfaces, notably the remnants of the Highland Rim surface. The pre-Chattanooga paleogeologic map (pl. 3) shows the effects of the earlier uplifts.

Throughout most of the area the rocks dip gently away from the crest of the Nashville dome at an average rate of about 10 to 15 feet per mile. Superimposed on this regional dip are many minor irregularities, such as small domes, anticlines, and basins. Local dips as high as $5^{\circ}$ are fairly common (pl. $4 C$ ). Faults at a few places are known, but are uncommon.

Structure contours of central Tennessee and adjacent areas are commonly drawn on the top of the Chat- tanooga shale (for example, Wilson, 1949, pl. 1; King and others, 1944), because it is an excellent horizon for surface mapping and is almost invariably noted in drill records.

In the southeastern part of the area of this report, in the region of Appalachian folding, the Chattanooga shale and Maury formation are relatively incompetent units and are badly sheared and crumpled (pl. $4 B$ ). In the deeply breached Sequatchie anticline, the Chattanooga shale and older rocks commonly dip $10^{\circ}$ or less on its southeastern flank, but on the northwestern flank steep dips, some of them vertical, are the rule. A major high-angle thrust fault conceals the Chattanooga in most places on the northwestern flank.

Walden Ridge, which is east of the Sequatchio Valley, is the southeasternmost part of the Cumberland Plateau. It is characterized by gentle dips except along its steep east wall, the Cumberland Front, where the rocks are so intensely folded that it is difficult to find good outcrops of the Chattanooga shale. Still farther east, in the main Valley and Ridge province of the folded Appalachians, all the rocks are intensely folded, faulted, and sheared, and most outcrops of the Chattanooga shale and Maury formation, where they can be found at all, are too highly disturbed to permit detailed stratigraphic study. The type locality of the Chattanooga shale (loc. 226; Hayes, 1894b, 1894c, 1894d), in the city of Chattanooga, is in this highly disturbed area.

\section{CRYPTOEXPLOSIVE (CRYPTOVOLCANIC) STRUCTURAI FEATURES IN TENNESSEE}

In three small areas of Tennessee the Chattanooga shale is associated with highly disarranged rocks in circular areas that are much like the Steinheim Basin of Germany for which Branca and Fraas (1905) coined the term "cryptovolcanic" (hidden volcano), in the belief that the feature resulted from some kind of explosion of magmatic origin. Later Dietz (1946) proposed that the term "cryptoexplosive" be used for such features; this word, which carries a less definite implication as to origin, is used in this report.

The origin of these structural features is unknown and is the subject of much speculation. Three theories most often considered in attempting to explain them are that they overlie salt-dome types of intrusions (Washburne, 1937), that they result from subterranean explosions of magmatic gas (Bucher, 1936), and that they result from the impact of large meteorites (Boon and Albritton, 1938a, 1938b). As this study has contributed little or no information on the origin of the features, their origin is not considered further in this paper. 
The Wells Creek cryptoexplosive feature in Stewart County is the best known of those in Tennessee. Here the Chattanooga shale and other rocks ranging in age from Ordovician to Mississippian have been strongly brecciated and faulted, and rocks in the central part of the structure are at least 1,000 feet above their normal position (Bucher, 1936, p. 1066-1070). The age of this disturbance is unknown except that it took place after middle Mississippian sediments had accumulated, and probably before Tertiary time.

The Howell feature in Lincoln County was described by Born and Wilson (1939). The Chattanooga shale is present locally over this disturbed area but is much younger than the disturbance and shows no abnormalities attributable to it. The disturbance apparently took place during the Ordovician period.

The third feature, at Flynn Creek, is described in the following paragraphs in some detail because it obviously influenced the accumulation of the Chattanooga shale.

\section{FLYNN CREEK FEATURE}

The Flynn Creek feature is near the northeast end of the Nashville Basin, about 5 miles south of Gainesboro, Jackson County (pl. 1), and is in the southern part of the Gainesboro 15-minute topographic quadrangle, where the maturely dissected topography has about 400 feet of relief. The disturbed rocks are exposed in the deep narrow valleys that have been cut through the undisturbed Fort Payne chert. The feature, as mapped, is slightly elliptical and has an average diameter of about 2 miles. Wilson and Born (1936), Lusk (1927), and Conrad, Elmore, and Maher (1954; 1957) described the structure. Many of the facts here stated are summarized from the reports by Wilson and Born, and by Conrad and others, but are supplemented by much additional information.

The Fort Payne chert in the area of the disturbance constitutes the upper 100 to 200 feet of the ridges; below it are the Maury formation, the Chattanooga shale, and the highly brecciated and disarranged blocks of Ordovician limestone that represents several formations. Wilson and Born (1936, p. 829) estimated that some of the blocks are as much as 500 feet above their normal position (fig. 3). The disturbance can be dated only as post-Middle Ordovician and pre-Late Devonian.

In the valley of Rush Fork, near the southeastern edge of the feature, 150 feet of Chattanooga is present between the Maury formation and the creek, and an additional 49 feet has been reported in the nearby Chaffin well in the valley bottom (Wilson and Born, 1936, p. 822). It thus appears that the shale in the disturbed area is locally about 200 feet thick, in contrast with that in the surrounding region which is only about 20 feet thick. Within the area of the feature the shale dips at various angles at least as high as $20^{\circ}$ (pl. $4 D$ ).

The limestone fragments below the shale range in size from powder to giant blocks measurable in hundreds of feet and are variously oriented as if they had been violently hurled about. Near the center of the feature the limestone extends upward somewhat like a secondary cone within a volcanic crater. Although full structural details of the area have never been determined, it appears that the Chattanooga shale fills a crater-like basin surrounding a central core. The core itself is overlain by a section of black shale thicker than that outside the disturbed area.

In the Flynn Creek area the abnormal thickness of the Chattanooga shale is almost wholly in its lowest unit. In a small creek in the northwestern part of the disturbed area (loc. 49), a bentonite bed in the upper unit of the Dowelltown member of the Chattanooga is present at its normal position about 17 feet below the base of the Fort Payne chert, virtually the same position as at nearby localities just outside the disturbed area. Below the bentonite, black shale is exposed down the creek bed to the base of the formation, which is 125 feet lower and some 500 feet closer to the center of the structure. If allowance is made for the dip of the shale

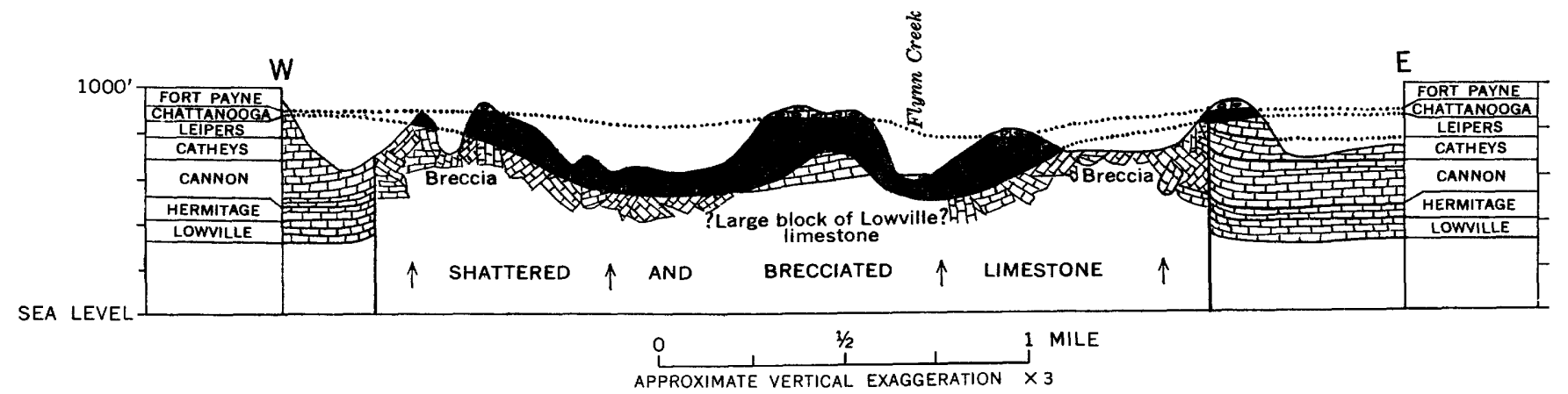

Frgure 3.-Cross section of the Flynn Creek cryptoexplosive feature, Jackson County, Tenn. Note the abnormal thickness of the Chattanooga shale, the relation of the shale to the underlying brecclated formations, and the sagging of the Fort Payne chert in the disturbed area. (From Wilson and Born, 1936, p. 824, fig. 3. Used by permission.) 
along the creek, the beds below the bentonite would have a true thickness of only 35 to 40 feet. It is more likely, however, that the lower beds of the Chattanooga have an initial dip and thicken to the south in a wedgeshaped manner, between horizontal top and a dipping floor, and that the actual thickness of the shale where the base was observed is about 140 feet. Apparently nearly all the extra thickness here, and probably elsewhere within the structure, is in the lower part of the Dowelltown member, the first part of the formation to be deposited. (See pl. 7 and fig. 5 for representations of the lithologic units of the formation in this part of Tennessee.) The same conclusion has been reached by other investigators (Conrad and others, 1957) who measured as much as $\mathbf{1 6 6 . 4}$ feet of beds of the Dowelltown member in the feature and observed that most of this overthickening is in the lower unit of the Dowelltown member.

The abnormally thick Chattanooga shale has previously been assumed to have accumulated in a crater that was present at the beginning of Chattanooga time, but to us that explanation is untenable. More likely, the disturbed area and the surrounding region had been reduced by erosion to a uniform level and the fragmental material in the structure subsided gradually during the accumulation of the black muds. Several types of evidence support these conclusions.

First, by whatever theory one explains the cryptoexplosive disturbance, it must be assumed that a large mass of rock was pushed or hurled upward; yet no trace of ejected fragments has been found at or below the base of the Chattanooga shale in the many wellexposed outcrops within 5 miles of the rim. It is inferred, therefore, that enough time for the removal of this debris elapsed between the shattering of the rocks and the deposition of the Chattanooga.

A second indication that no crater existed just prior to Chattanooga time is the absence of lake deposits and of rock debris from the walls of the supposed crater. A crater 200 feet deep on the Devonian peneplain would doubtless have contained a lake in which plant remains and mud would have accumulated and into which rock debris would have been washed from the walls. However, no lake deposits appear to be present between the explosion breccia within the disturbed area and the overlying Chattanooga shale. Wilson and Born (1936, p. 821-822) described a "bedded breccia" that is present locally just below the black shale, and later Conrad and others (1957, p. 16) described the same material as a "fresh-water" limestone. Examination of this limestone in the creek bed of Cub Hollow near Antioch School by Hass (oral communication,
1949) revealed lower Upper Devonian conodonts. The example of talus breccia cited by Wilson and Born (p. 821 ) is probably land-slip material of Recent age. It appears to us, therefore, that the first sediment deposited within the "crater" was a marine deposit of early Late Devonian (Chattanooga) age.

The observed dips of the shale are a third indication that the basin was formed during Chattanooga deposition. Within the area of abnormal thickness, the lower beds of Chattanooga shale customarily dip as much as $20^{\circ}$ toward areas where it is thickest. It is highly unlikely that the fine muds could have accumulated on the steep slopes to thicknesses of many tens of feet without slumping toward the deeper areas. Because the beds show no sign of slumping, it is believed that the layers of mud accumulated in a nearly horizontal position and acquired a dip toward the center of the structural feature only after burial and subsequent depression.

A fourth type of evidence against a pre-existing "crater" is the almost identical appearance and composition of the abnormally thick shale and the normal shale of the surrounding region. Had the muds accumulated in a deep crater, even one that came into existence at the beginning of Chattanooga time, they would almost certainly have differed from the normal shale in grain size, organic content, and bedding characteristics. Instead, the similarity in both composition and stratification strongly suggests that the muds accumulated under virtually the same conditions as those in which the Chattanooga muds accumulated elsewhere.

The following proposed explanation of the thick accumulation of mud in the Flynn Creek area seems consistent with the observed facts: Whatever the origin of the explosion or disturbance, sufficient time followed for any ejected debris to be removed and for the area to be leveled by weathering and erosion. By the time the Chattanooga sea reached the region, the surface was nearly as smooth as that elsewhere on the peneplain. Upon flooding by the Chattanooga sea, some of the finer fragmental limestone material was reworked into the strictly local deposits of sedimentary breccia that contain the Upper Devonian conodonts. The "bedded breccia" of Wilson and Born, or "fresh-water" limestone of Conrad and others is thus merely a local facies of the basal sandstone bed of the Chattanooga shale, a bed that elsewhere varies greatly in composition according to underlying rock types (pp. 23, 25). Acid sea water, whose presence is indicated by the black shale, is assumed to have had a greater dissolving power on the limestone than did the ground water that had previously saturated the breccia. As the supply of acidic water became plentiful it may have caused solution and 
compaction of the loose limestone breccia and powder to considerable depths within the structure. The steadily increasing weight of the overlying muds may have contributed to the settling process. Once the subsidence started, a slight depression was formed on the sea floor and mud could migrate into it from the surrounding area.

By this explanation, the lower beds of the Chattanooga shale would not acquire dips of appreciable magnitude until they were buried beneath many tens of feet of overlying mud and were sufficiently confined or indurated that they did not flow.

The settling process, which involved more than 150 feet of lowering of the original surface, was largely completed by the time the lower unit of the Dowelltown member had been deposited, as indicated by normal thicknesses of the overlying units of the shale and the Maury formation. Over the thickest part of the Chattanooga shale in the Flynn Creek crater, however, the Maury formation and the overlying Fort Payne chert are as much as 100 feet lower than in the surrounding area (fig. 3). This lower position of the higher beds over the disturbed area is presumably a measure of the differential compaction of the abnormally thick shale as compared with the normal shale in the nearby surrounding area, in consequence of the load of about 1,000 feet of rocks of Mississippian age and an unknown thickness of rocks, probably at least 1,000 feet, of Pennsylvanian age. It is especially noteworthy that any compaction of the muds in excess of about onethird of original thickness had to take place before the end of Chattanooga time, for the contents of the 300foot-deep crater are now only 200 feet thick. Even more notable is the fact that most of this early compaction took place during Dowelltown time; had it continued through Gassaway time, the Gassaway member would presumably have an abnormal thickness.

A similar excessive thickness of a formation overlying a cryptoexplosive area is at the Howell feature in Tennessee where the Fernvale formation has abnormal thickness and dips. Born and Wilson (1939, p. 382) postulated a simultaneous subsidence of the crater floor and deposition of the sediments, events parellel to what we believe happened at Flynn Creek.

A possible corollary to the theory of simultaneous subsidence and deposition carries definite implications regarding sedimentation that occurred in the Chattanooga sea. It has just been shown that the subsiding crater area must have been filled with black mud from the surrounding area, yet measurements of the black shale over a large part of Tennessee show that it has no tendency to be significantly thinner near the Flynn Creek area than elsewhere in that part of the State. It seems, therefore, that mud on the sea floor was sufficiently agitated, even though weakly, that it moved about and tended to fill any low places. This shifting of the mud particles, though slight at any one time, was probably enough to keep the Chattanooga sea floor well graded at all times. The mud particles may well have moved many miles along the sea bottom before they reached their present places.

\section{CHATTANOOGA SHALE}

The Chattanooga shale is part of a blanket of black shales of early Late Devonian (or possibly late Middle Devonian) to Early Mississippian age that are present throughout much of the interior of North America. The general distribution and nomenclature of these black shales and their correlative rocks in the United States are shown on plate 14. Black shales of similar age continue northward from Montana under the Great Plains province of Canada.

\section{HISTORY OF THE NAME}

The black shale of Tennessee was recognized as a persistent and distinctive unit at least as early as 1835 , when it was described by Troost (1835, p. 6-8) as "aluminous slate or shale" [italics by Troost]. In 1837 he noted (p. 15) that a siliceous stratum [Fort Payne chert] is always separated from the underlying limestone sequence $" * * *$ by a bed of argillaceous schiste (ampelite alumineux) of a black color, containing pyrites and occasionally small seams of bituminous matter, resembling sometimes coal." His reports of 1840 (p. 16-17), 1841 (p. 33), and 1843 (p. 18-22, 29) refer to it as aluminous slate or simply as shale or slate.

In 1851 Safford (p. 352, 358-359) referred to the "black or bituminous slate," or simply the "black slate" as one of the five major stratigraphic divisions of middle Tennessee. In 1856 (p. 158) he again referred to it as the "black shale," but in 1869 (p. 151, 154, 162$163,329-337)$ he consistently called it black shale.

In 1891 Hayes (p. 142, 143) applied the geographic name "Chattanooga black shale" but did not specify a type locality. In 1894 he stated in three U.S. Geological Survey folios (Nos. 4, 6, 8) : "Typical exposures of this shale appear in the north end of Cameron Hill, within the city limits of Chattanooga, from which locality it takes its name." Cameron Hill is thus the type locality, though the outcrop is on a thickly wooded slope, is badly weathered, and is too deformed by folding and faulting to permit detailed study (for photograph of the outcrop see Hass, 1956, pl. 5). Gradually the word "black" has been dropped, in accordance with generally accepted practice, and the unit is now known as the Chattanooga shale. That name has been widely adopted 
for strata in Tennessee, Georgia, Alabama, Mississippi, Kansas, and parts of Arkansas, Oklahoma, Kentucky, Illinois, and Missouri.

In 1870 Andrews (p. 62) applied the name "Ohio black shale" to outcropping beds in Ohio that are of Late Devonian age and are virtually correlative with the Gassaway member of the Chattanooga shale in Tennessee. That term is generally used for beds in northern Kentucky on the east side of the Lexington Basin, where the black shale of Devonian age can be distinguished from the overlying Sunbury shale of Mississippian age by the presence of the intervening and distinctive Petersville shale of Morse and Foerste (1909), which is a thin representative of the Bedford shale and Berea sandstone of Ohio.

In 1874 Borden (p. 150, 152, 158, 172) applied the name New Albany shale to black shale in southern Indiana that is a partial correlative with both the Ohio shale of Devonian age and the overlying Sunbury shale of Early Mississippian age. That name is now commonly used also for beds in northern and central Kentucky west of the region where the presence of the Bedford shale and Berea sandstone permits the Ohio and Sunbury shales to be distinguished; it is also used for beds in southeastern Illinois. The same beds in the subsurface of western Kentucky, however, are commonly called the Chattanooga shale.

The names Ohio shale and New Albany shale have 21 and 17 years priority, respectively, over the name Chattanooga shale, and one of them should, perhaps, by a strict application of the principle of priority, replace the term Chattanooga shale, although the three names were applied to rocks having somewhat different, though overlapping, age ranges. For nearly 50 years suggestions to that effect have been made (for example, Ulrich, in Ulrich and Smith, 1905, p. 25), but none received wide acceptance.

Freeman (1951, p. 43) proposed that the names Ohio, Chattanooga, Sweetland Creek, and Antrim all be abandoned in favor of New Albany shale because, in spite of some differences in age, the beds so designated represent a continuous depositional unit ranging from Late Devonian to Mississippian. She stated:

If one name is to be used it should be the one first applied. The term Ohio shale was used a little before that of New Albany but it is not so inclusive.

*** because this black shale is such a convenient marker and more widely used than any other in the Paleozoic, a single name for the unit seems desirable. It is suggested here that, since New Albany has priority as an inclusive term, it should be in use generally.

Although there is logic in this argument, widespread usage of long standing has so firmly entrenched the name Chattanooga shale in the literature and in the records of geological surveys and of industrial companies that to abandon it now would cause more confusion than seems warranted. For that reason we continue to use the term "Chattanooga shale."

In the 19th century both Safford (1869, p. 330) and Hayes (1891 and several later reports) included in the Chattanooga shale the overlying thin unit of greenish, more or less glauconitic and phosphatic shale, siltstone, or sandstone. Later Safford and Killebrew (1900, p. 104, 141-143) treated it as a separate unit. Since then the tendency has been to recognize it as the Maury member of the Chattanooga shale, as the basal bed of the immediately overlying formation, or as a separate formation. In this report it is treated as the Maury formation.

\section{PRE-CHATTANOOGA SURFACE GENERAL CHARACTER}

Throughout the area of this study the Chattanooga shale rests on a peneplain that is notable for its extent and degree of perfection. In the Tennessee area alone the shale rests on no less than 23 different sedimentary formations (pl. 3), as mapped by Wilson $(1949, \mathrm{pl} .2)$, ranging in age from Middle Ordovician to Middle Devonian. The older beds were tilted so slightly before Chattanooga time that in most outcrops the shale appears to parallel the older rocks; at a few places an angular discordance is visible (pl. $5 A$ ) but is rarely as much as $1^{\circ}$. Limestones, sandstones, and shales were beveled and planed during what must have been a time of unusual crustal stability until a wide area was reduced to an almost featureless plain barely above sea level. Similar stability, except for a probable slight general subsidence, continued throughout Late Devonian and Early Mississippian time as the sea progressively spread and inundated more and more land; even the Nashville dome, notable for its several earlier and later uplifts, shows evidence of only slight arching during that time.

Further evidence of the smoothness of the pre-Chattanooga peneplain is the uniformity in thickness of the Chattanooga shale. The several lithologic units of the shale are notable for their nearly constant thicknesses in large areas along the eastern edge of the Nashville Basin, and probably beneath much of the Eastern Highland Rim. Evidence in the Flynn Creek area indicates that the muds were carried to low points and that current action kept the sea floor well graded. Along most of the eastern edge of the Nashville Basin even the lower unit of the Dowelltown member commonly has a thickness of about 4 to 7 feet, and at only a few places is it much thinner or thicker. 
In general the rate of thickening or thinning of the Chattanooga shale is remarkably low. Over the entire area, with the exception of Flynn Creek and a few other small areas where special conditions prevailed, the average rate of thickening or thinning is about 3 to 5 inches per mile. Several lines of sections, from 20 to 60 miles long, could be drawn to illustrate this gradual change of thickness. The line of section in figure 4 shows an average northward increase of thickness, away from an island area, of about 3 inches per mile for 15 miles. A similar gradual and regular thickening eastward from the same island area can be seen at locality 138 near Bodenham in western Giles County where a succession of outcrops shows a regularly increasing thickness of the shale. Here, in a creek bed, 100 yards east of the Giles-Lawrence County line, about 0.35 foot of phosphatic siltstone of the Maury formation rests directly on basal sandstone, and no black shale is present; 50 yards downstream, at the site of a big spring, about 0.06 foot of black shale is present between the Maury and the basal sandstone of the Chattanooga; and another 75 yards downstream the black shale wedge is about 0.9 foot thick. Outcrops farther east show progressively greater thicknesses of the shale. These two examples of gradual onlap of the Chattanooga shale are believed to typify conditions that existed regionally as the sea spread slowly over the peneplain.

\section{SUB-CHATTANOOGA RESIDUUM}

Instead of the normal sharp contact between the Chattanooga shale and the underlying fresh limestone, a residual silty clay is present below the shale at many outcrops throughout the area of this study (pl. $5 B$ ). The clay ordinarily ranges in thickness from a few inches to at least 15 feet and is various shades of orange and brown. For the most part it is unstratified and structureless except that it commonly has a coarse and variable color banding, the most conspicuous bands being nearly black because of the presence of manganese oxide. Locally the clay contains uncompressed molds of fossils like those of the underlying limestone. It has a sharp upper contact with the Chattanooga shale, and commonly rests abruptly on weathered limestone that has an irregular or even pinnacled upper surface. The weathered limestone grades downward through an interval of several feet into fresh limestone. The residuum has been found by careful search at about a quarter or a third of all the examined outcrops of the Chattanooga, though at many it is found only when the concealed basal contact of the shale is dug out.

The residuum is most often found in highway cuts where only 10 or 20 feet of the shale is present, but exceptionally it is overlain by the entire thickness of the shale. At some places the shale above the residuum is considerably cracked and slumped, but at others it shows few fractures or signs of slumping.

This silty clay, obviously formed by weathering of the underlying limestone seems to permit only two explanations of origin: Either it is an ancient limestone residuum that was buried by the black muds of the Chattanooga sea, or it is the insoluble residue from limestone that has been dissolved by ground water or surface water, or both, since the time of Chattanooga deposition. It is probable that most, and perhaps all, of the residuum was formed since the land surface was eroded to about its present position.

The residuum has been observed below the black shale by several previous writers, some of whom thought of it as a pre-Chattanooga residuum, though they presented few arguments to support their opinion. Foerste (1901, p. 430-431) mentioned residual soil at the base of the Chattanooga shale in the Tennessee phosphate area. Ulrich (1911, p. 454-459, 464-465) discussed the presence of residual soil along unconformities and mentioned such material as being either just below or in the base of the Chattanooga but cited no convincing evidence at localities within the area of our investigations. Kindle (1912, p. 122-123) described and illustrated residual clay below the black shale and considered it to be definitely a residuum on the preChattanooga land surface. Later Jillson (1951a, p. 48; $1951 b$, p. 5-6) mentioned the presence of an "old soil" below the Chattanooga shale in Cumberland County (loc. 14A), but he did not describe it or present evidence of its origin.

Several facts suggest a pre-Chattanooga age for the residuum: (a) Superficially it looks somewhat like the residuum in present-day limestone areas, except that nothing resembling the $\mathrm{A}$ and $\mathrm{B}$ soil horizons of pedologists has been identified; (b) in some places the rocks above and below it show no excessive recent weathering; (c) the residuum has been observed only at the contact between the impervious Chattanooga shale and the almost impervious underlying limestones; (d) at most exposures of the residuum the clay can be traced laterally as far as the base of the shale is exposed.

On the other hand, a post-Chattanooga age of the residuum is indicated by the following facts: (a) The residuum has not been found in the freshest deep highway cuts, but only at outcrops where there has been a possibility of recent weathering or where roots have been able to penetrate; (b) the residuum is not present in any of the 75 drill cores that have penetrated the lower contact of the shale; (c) petrographic study by Charles Milton of the U.S. Geological Survey has 


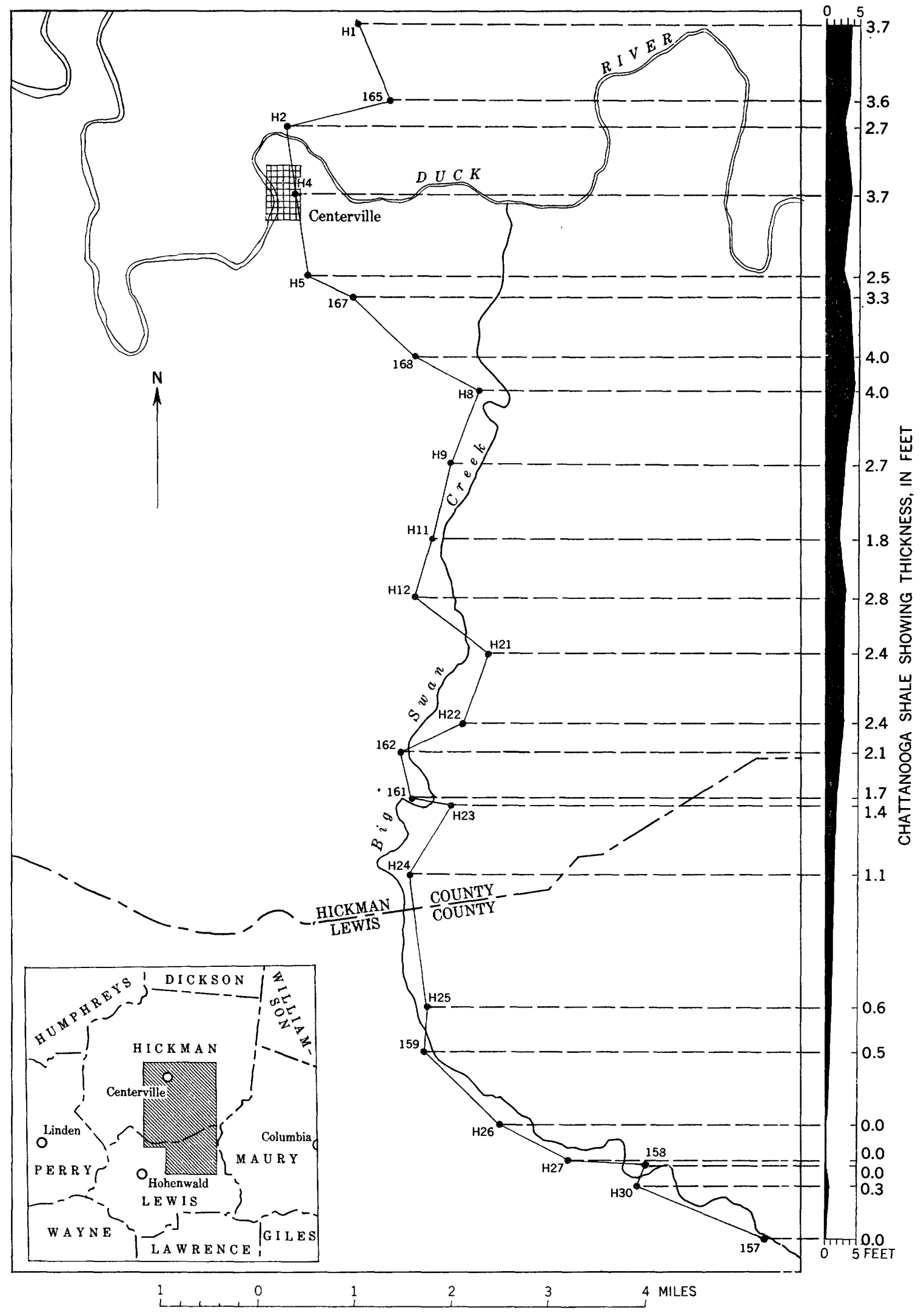

FIGURE 4.-Map and cross section of the Swan Creek area of Tennessee showing the gradual thickening of the black shale unit of the Chattanooga shale seaward from a large island. In 15 miles the average rate of thickening is about 1 foot in 4 miles. The basal phosphatic sandstone ("blue phosphate") is omitted in this compilatiou. 
shown the presence of abundant rhombohedral voids, indicative of the removal of calcite or dolomite crystals by solution-cavities that could hardly have existed throughout a long period of soil formation and subsequent compression beneath 1,000 to 2,000 feet of overlying rocks; (d) the empty molds of calcareous-shelled fossils could also have hardly escaped being compressed and destroyed.

Milton concluded (Milton and others, 1955) that surface water seeping through cracks or over the outcropping surface of the shale became sufficiently charged with sulfuric acid derived from the disintegration of pyrite to attack the underlying limestone. This process removed most of the calcium carbonate but left a clayrich residuum. Among the products of this process is the rare mineral basaluminite $\left(2 \mathrm{Al}_{2} \mathrm{O}_{3} \cdot 3 \mathrm{SO}_{3} \cdot 10 \mathrm{H}_{2} \mathrm{O}\right)$ that was first described only a short time before its discovery in Tennessee (Hollingsworth and Bannister, $1950)$.

In some places the solution of the limestone has allowed the overlying shale to settle and crack, but in other places surprisingly small amounts of subsidence have taken place. Possibly subsidence has been delayed by the presence of enough undissolved pinnacles and ridges to permit the shale to span the areas of deeper solution without appreciable failure.

The thickest known exposure of this sub-Chattanooga residuum is 8 miles southwest of Gainesboro, Jackson County, Tenn. (loc. 51). There a 15-foot handauger hole penetrated a nearly homogeneous and unstratified silty clay without reaching the limestone, and scattered poor exposures down the hill show similar material for another few feet. Just west of Gainesboro (loc. 40) a recently widened highway cut shows a continuous layer of the residuum extending for 100 to 200 feet, ranging in thickness from about 4 inches to $2 \frac{1}{2}$ feet and lying on an irregularly pinnacled surface of leached limestone. One of the best places to see a complete cross section of the residuum resting on an irregular limestone surface is about 7 miles northwest of Manchester (loc. 108). There the residuum ranges in thickness from a few inches to about $2 \frac{1}{2}$ feet, and has marked color bandings, apparently the result of different degrees of concentrations of manganese and iron oxide at different vertical positions.

On the western side of the Nashville Basin similar material is present beneath the Chattanooga shale at over half the observed outcrops. Near Pulaski, black shale overlies residuum that occupies small troughlike depressions as much as 5 feet deep between pinnacles of the limestone (pl. $5 B$ ).

\section{AGE OF THE CHATTANOOGA SHALE}

HISTORICAL SUMMARY

For 75 years geologists have held conflicting opinions on the age and correlation of the Chattanooga shale. It has been generally agreed that its age is Late Devonian or Mississippian, but there the agreement ends. Some investigators have thought the black shale is of Late Devonian age, others have been convinced of its Mississippian age, still others have thought it is of both ages, and a fourth group has considered it a timetransgressing near-shore facies of different ages in different places.

Ellison (1946, p. 102) summarized the status of the controversy as follows:

*** there exist three present-day interpretations of the age of the Chattanooga and its equivalents. The paleobontanists, some conodont workers, and the United States Geological Survey geologists have much evidence that these formations are in the greater part Devonian in age. A number of workers, including some petroleum geologists and a few State Geological Survey men, prefer to remain neutral and classify the Chattanooga problem as Mississippian-Devonian. Many petroleum geologists, some conodont workers, and a number of State Geological Survey men believe that these beds are definitely Mississippian in age.

Many papers have been written on the age of the Chattanooga shale and its correlatives, but much of the published information is incorrect and inaccurate. The chief reason for the lack of acceptable data is the general absence, except at a few widely scattered localities, of the fossils commonly used in determining the age and correlatives of a formation; instead, the shales contain inarticulate brachiopods, a few arthropods, spores and other plant remains, fish remains, conodonts, and other fossils that are not commonly used. Of these fossils, conodonts are now considered to be the best indicators of the age and correlatives of the stratigraphic units that constitute the black shale sequence. Significant conodont genera are common in the black shales, and the age interpretations of this report are based on a detailed study of the conodonts by Hass (1956).

Many attempts to determine the age of the Chattanooga shale have been based on apparent gradations or close associations with rocks of known age and on unconformities that investigators have supposedly identified in the sequence. Abrupt and widespread lithologic changes have been interpreted as unconformities, different thicknesses of the Chattanooga have been assumed to indicate erosion at the end of Chattanooga time, and a layer of large phosphate nodules at the base of the Maury formation has even been mistaken for a basal conglomerate. 
Both Safford (1869) and Hayes (1891 and later) considered the Chattanooga shale to be of Devonian age, and it was generally so accepted for many years.

In 1898 Girty summarized the then-known scanty faunal evidence on the age of the black shales in the east-central States. Few fossils had been found that could be correlated with the standard Devonian section in New York, yet nearly all the evidence pointed to a Middle or Late Devonian age (Marcellus or Genesee).

In 1905 Ulrich embarked on a notable series of controversial statements concerning the black shale when he proposed (in Ulrich and Smith, p. 25) that the term Chattanooga be abandoned in favor of the older term Ohio shale. Grabau (1906, p. 599) rejected this proposal, and Ulrich later reverted to using the term Chattanooga.

In 1906 Grabau (p. 593-613) challenged Girty's conclusion that the black shale is of Devonian age by expressing the view that it is a basal facies of a sedimentary sequence formed in a transgressing sea, and that its age ranges from Late Devonian to Early Mississippian. In following years this theory was widely seized upon by proponents and opponents, and the "black shale controversy" was well underway.

In 1909 Morse and Foerste published the significant discovery that the Sunbury and Ohio shales, which are separated in Ohio by the Bedford shale and Berea sandstone, merge southward in Kentucky by the thinning and disappearance of the Bedford and Berea. At Irvine, Estill County, Ky., 3 feet of Sunbury shale (Mississippian) is separated from 94 feet of Ohio shale (Late Devonian) by only $1 \frac{1}{2}$ feet of the Petersville shale of Morse and Foerste. Morse and Foerste also showed that the Sunbury shale thins southward more gradually than does the Petersville, so it probably continues beyond Irvine and rests directly on the Ohin shale. The fact that the topmost black shale in eastern Kentucky is of Mississippian age and that the rest is of Late Devonian age has been variously cited by disputants during the succeeding years of the controversy, yet stratigraphic and fossil evidence tied to this relationship has at times been misinterpreted, distorted, or ignored.

In 1912 Ulrich prompted further controversy by proposing that some of the black shale units of the eastern United States be removed from the Devonian system. Like Grabau, he was of the opinion that the black shales are of different ages in different places, but he was impressed by the magnitude of the unconformity at the base of the shale and believed that systemic boundaries should be based on world-wide diastrophisms. Accordingly, he proposed that the range of the Waverlyan system (the now-abandoned term for the lowest part of the Carboniferous systems) be extended downward to include all the Chattanooga shale and several other black shale correlatives, thereby assigning them to what is now known as the Mississippian system. He further proposed that a new series, the Chattanoogan, be established at the base of the Waverlyan system to include the Huron, Olmsted, Cleveland, and Bedford shales, the Berea sandstone, and the Sunbury shale, all of Ohio, and the Chattanooga shale of Tennessee and Kentucky. Ulrich's suggestions on the age and classification of the black shales were not accepted.

Kindle was one of the few writers who immediately rejected the opinions of Grabau, Ulrich, Bassler, and others who advocated a Waverlyan (Mississippian) age of the Chattanooga shale and much or all of the Ohio shale. Concerning one of the statements that had been made on the age of the black shales he wrote (1912, p. 128) :

[It] is comparable to some which have followed it in the poverty of evidence on which it rests and the positive phrasing which might mislead one unfamiliar with the subject to suppose that it represents an established fact.

Kindle also called attention to the abundant conodonts that are present throughout the Chattanooga shale and in the related black shales "from Lake Erie to Alabama" and correctly predicted $(1912$, p. 128$)$ the valuable evidence they would someday supply:

When they [conodonts] have been described and the species which are confined to the upper and lower horizons of the shale distinguished, they will prove an invaluable aid in correlating the different parts of the Ohio shale in Ohio with their equivalents in the Chattanooga shale in Kentucky and farther south. Until this has been done, however, any attempt to make use of these fossils in correlating subdivisions of the Ohio and Chattanooga shale must be considered premature and futile.

The views of Kindle on the age and correlation of the Chattanooga shale do not differ materially from those later presented by Hass (1956), views that were based, as Kindle predicted, on a careful study of the conodonts from the large area between New York, Tennessee, Oklahoma, and Michigan.

Mather (1920) believed that in Sumner County, Tenn., and Allen County, $\mathrm{K}_{\mathrm{y}}$, there are really two black shale formations separated, at least locally (our loc. 206 in Sumner County), by an angular unconformity. He considered that the upper was of Mississippian age but thought the lower might be of Devonian age. He recognized the thin sandstone bed at the base of the upper unit that Campbell (1946) later named the Bransford sandstone member of his Gassaway formation. Mather proposed no revision of the black shale terminology. 
Swartz (1924) early in his investigations considered most of the Chattanooga shale at Chattanooga and some nearby areas to be of Cleveland age, but he believed the uppermost part to be of Mississippian age. Later work $(1926,1927)$ in northeast Tennessee and southwest Virginia led him to assign similar ages to a much thicker and presumably equivalent shale sequence in that area. Still later (1929) he concluded, on the basis of fossils found in the middle unit of the succession, that most, and perhaps all, of the shale sequence in northeast Tennessee and southwest Virginia is of Mississippian age, and that all the formation in the Chattanooga area is of Mississippian age.

In 1930 Morse (p. 55-61) reasoned, largely on the basis of a supposed overlying unconformity, that an impure sandy and gray shaly facies of the Chattanooga shale in northeast Mississippi, which he termed the Whetstone Branch formation, is of Devonian rather than Mississippian age. He was one of the few investigators after 1925 who insisted on a Devonian age for the Chattanooga shale.

In 1930 Savage (p. 14-21) presented evidence that the New Albany shale of Kentucky is of late Devonian age (Tully and Genesee).

Pohl (1930) stated that the Chattanooga shale consists of two distinct formations separated by a widespread and significant unconformity and that both are of Mississippian age. Another black shale unit, present locally below these in the northern part of Tennessee, he designated as the Trousdale shale, which, he stated, contains fossils permitting a correlation with Genesee-Portage black shales of the Devonian sequence in New York; for this new unit he cited no paleontologic information and mentioned no specific localities.

In 1931 Savage and Sutton summarized briefly previous views regarding the age of the black shales in Ohio, Kentucky, and Tennessee. They presented evidence that the lower part of the Chattanooga shale in Allen County, $\mathrm{Ky}$., is of Late Devonian age, but that locally some beds of Mississippian age are present at the top. They differed from Pohl as to the relative. amounts of Devonian and Mississippian strata present, as shown by their closing statements (p. 448):

we disagree with him [Pohl] in his conclusion that the Upper Devonian is represented in this part of Kentucky and northcentral Tennessee by only local occurrences of black shale. Our studies would indicate that the Mississippian phase of the black shale, rather than the Devonian, is the one which is local in its occurrence.

In 1932 Bassler (p. 137) stated that not one of the 50 species of conodonts studied by him and Ulrich from the black shale in Alabama and Tennessee is identical to a species from an equally large assortment from
Devonian shale in New York, but that many are identical with those found in the Mississippian in northern Ohio. These opinions influenced many geologists and some State geological surveys to reclassify the Chattanooga shale as of Mississippian age. It should be pointed out, however, that Bassler's Mississippian shale units in Ohio are parts of the Ohio shale which is generally considered to be of Devonian age but which Ulrich (1912) assigned to his Waverlyan system. The supposed Hardin sandstone collection from the Mount Pleasant area in Maury County, Tenn., where a large number of the southern species were collected (see Ulrich and Bassler, 1926), is overlain directly by the Maury formation. In that area no black shale is present. The abundant conodonts in the sandstone in question are identified by Hass (1956) as Upper Devonian species, and he considers that the sandstone is equivalent to a part of the Gassaway member of the Chattanooga shale. However, as it is a very thin sandstone unit immediately underlying and lithologically tied to the Maury, it is here referred to as the basal sandstone of that formation.

Huddle (1933) concluded from a study of the conodants that most of the New Albany shale in southern Indiana and northwestern Kentucky is of Late Devonian age and that only the uppermost 5 to 10 feet is of Mississippian age. Although he did not extend his studies south to the area of the black shales that are commonly known as Chattanooga shale, his conclusions are significant because they differ from the earlier ones of Ulrich and Bassler based on conodonts. Huddle's studies may be considered the forerunner of the ones that are restoring most of the Chattanooga and the equivalent New Albany shale to the Late Devonian.

Klepser (1937), in a thesis published only in abstract but quoted freely by Stockdale (1939), accepted in general the Grabau theory of progressive overlap to the south and of the Mississippian age of the Chattanooga shale. His reasoning was based on (a) the apparent conformable relations that exist between the Chattanooga shale, Maury formation, and overlying formations, and (b) his conclusions that the formations next above the Maury are progressivly younger to the south. He stated, as quoted by Stockdale $(1939$, p. 55):

Since the Maury is conformably overlain by formations of various ages, ranging from Fern Glen to upper Keokuk, it follows therefore, that the Maury, and the Chattanooga which everywhere grades up into the Maury, must be time transgressing units, representing the basal shore phase of a sea advancing southward. ***

The advocates of a Mississippian age for the Chattanooga shale have, with a few exceptions, stated that the shale is of Kinderhookian age. As the evidence to be introduced *** will attempt to show, however, the Chattanooga shale of east- 
GEOLOGICAL SURVEY

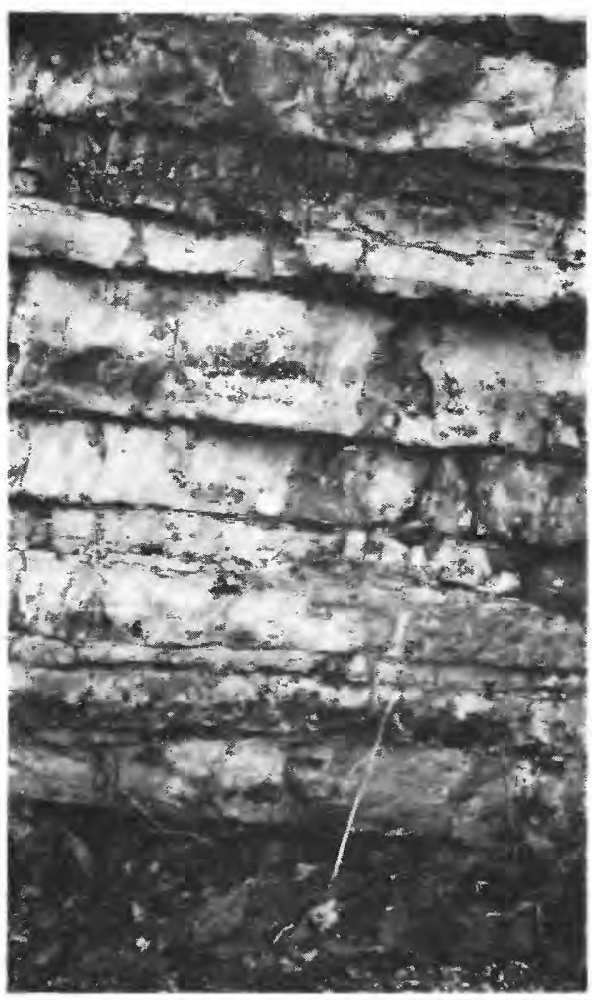

A. BASAL PART OF THE FORT PAYNE CHERT

Characteristic layers of almost solid chert from 2 to 12 inches thick. Watch near center gives scale. Locality 78. Photograph by Andrew Brown, 1948.
PROFESSIONAL PAPER 357 PLATE 4

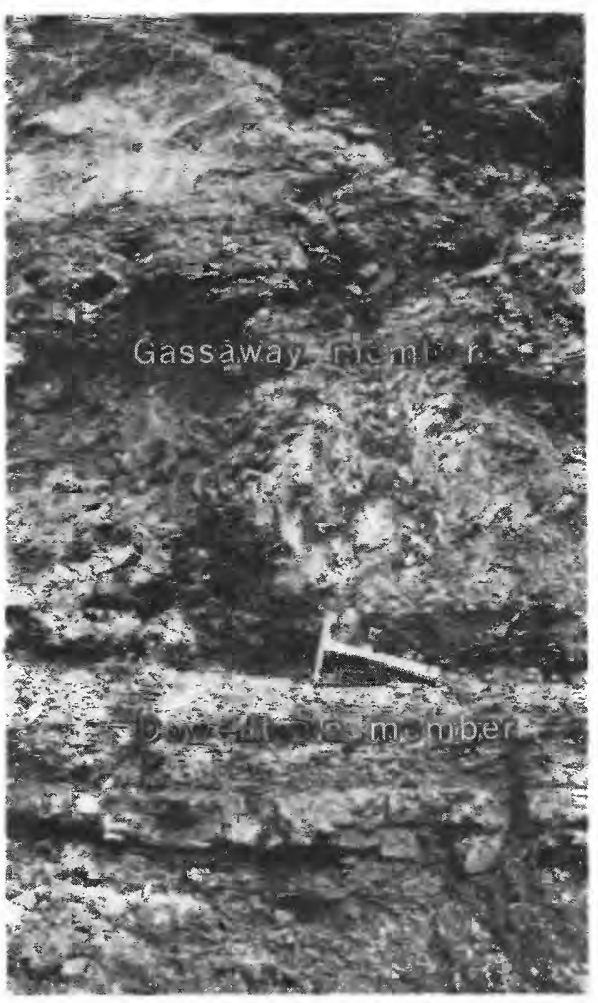

B. FOLDED AND CRUMPLED BEDS OF THE UPPER (GASSAWAY) MEMBER OF THE CHATTANOOGA SHALE ON EAST SIDE OF THE SEQUATCHIE VAILEX

Below the hammer, nearly a foot of shale of the lower (Dowelltown) member rests on the hasal sandstone, here about 8 inches thick. Locality 220. Photograph by R. C. Robeck, 1948.

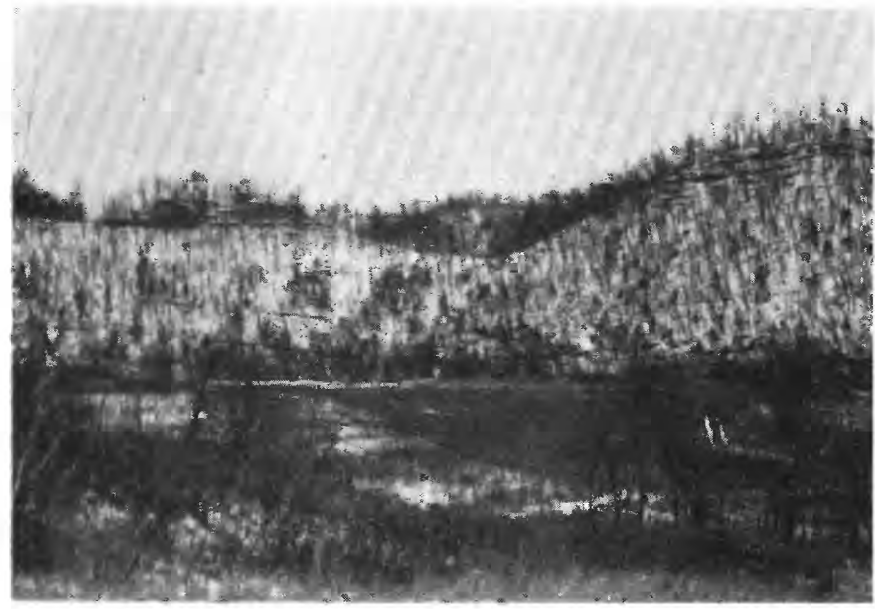

C. GENTIE SYNCLINE IN THE EASTERN HIGHLAND RIM AREA

The gap near center cuts through the Chattanooga shale, the one at left cuts into it The steep slope at right rises about 400 feet above Caney Fork, which is just below field level. Center Hill Reservoir now covers the field in the foreground. Locality is just downstream from Sligo bridge, De Kalb County, Tenn. 1948.

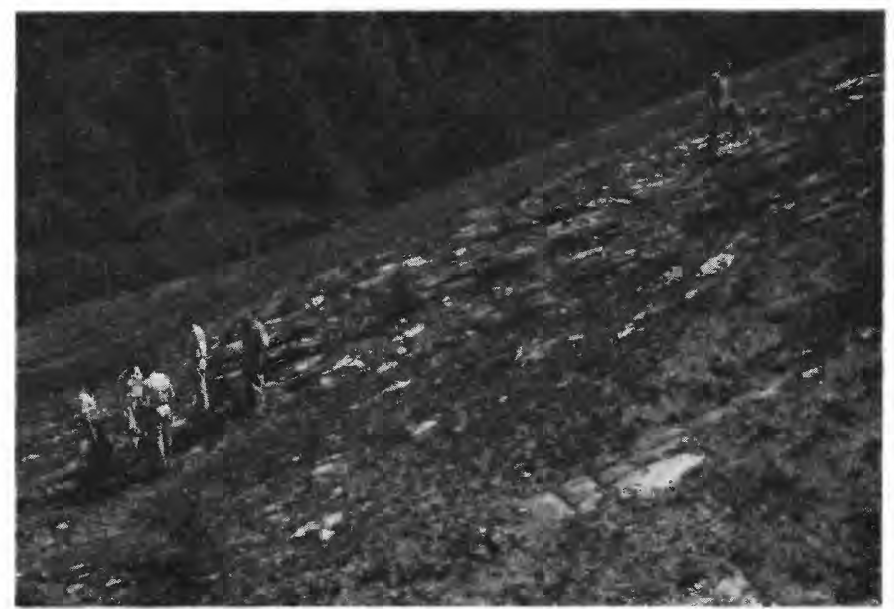

D. DIPPING BEDS OF THE CHATTANOOGA SHALE ON SLOPING SIDES OF THE FLYNN CREEK CRYPTOEXPLOSIVE FEATURE

The shale dips about $20^{\circ}$. At several places on this slope, including the foreground outcrop, the underlying brecciated limestone is well exposed. South side of Flyn Creek, about half a mile west of Antioch school and church, Jackson County, Tenn. 1952. 


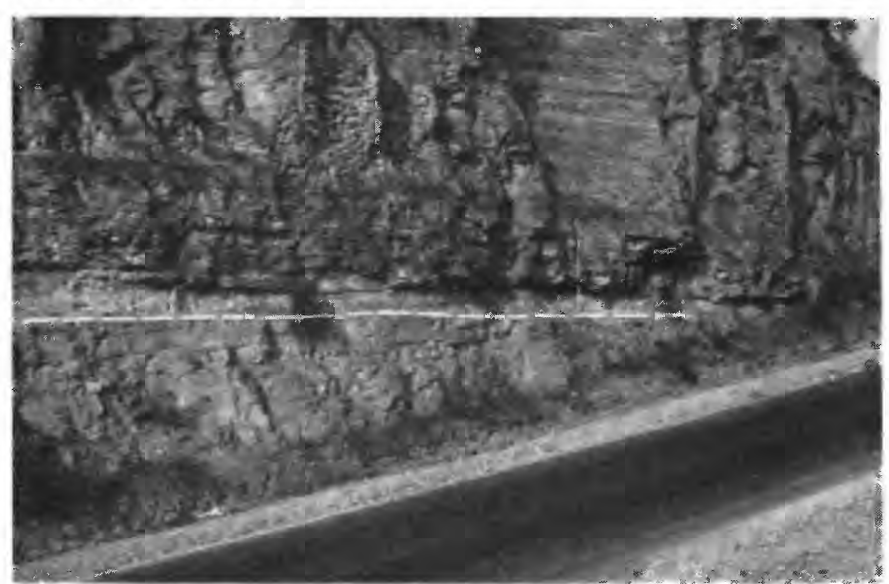

A. ANGULAR UNCONFORMITY OF ABOUT $4^{\circ}$ AT BASE OF CHATTANOOGA SHALE, WEST OF NASHVILLE, TENN.

The 6 -foot rule stands on limestone of Silurian age (as mapped by Wilson, 1949) at base of Chattanooga shale, marked by the white line; top of rule is just below the Maury formation, which is here about 0.6 foot thick. Higher beds are New Providence (Ridgetop) shale. Locality 196.

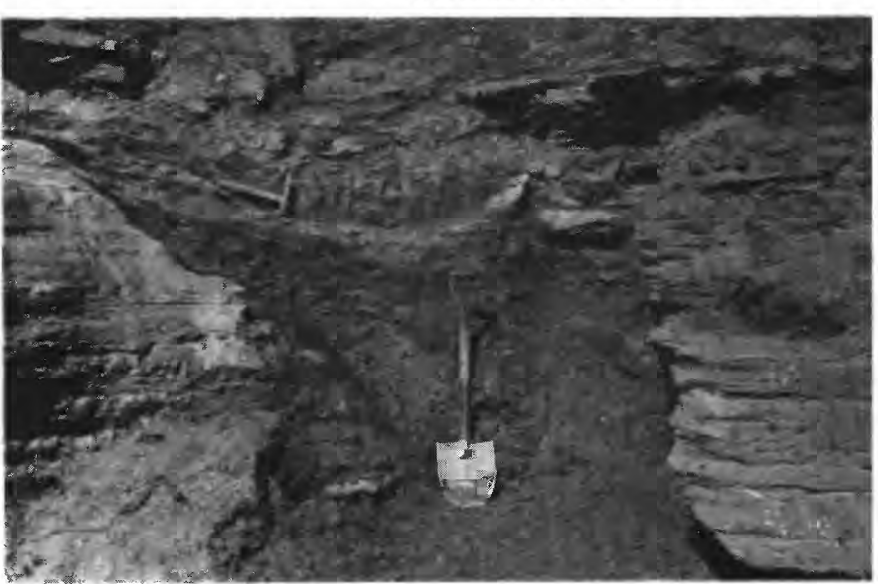

b. SUB-CHATt ANOOGA RESIDUUM NEAR PUlaski, GILES COUNTY, TENN.

The shovel leans against residuum between limestone pinnacles. The hammer rests on a residual layer of chert that can be traced into the pinnacles. Upper part of photograph shows Chattanooga shale somewhat slumped. Locality 137. 1951.

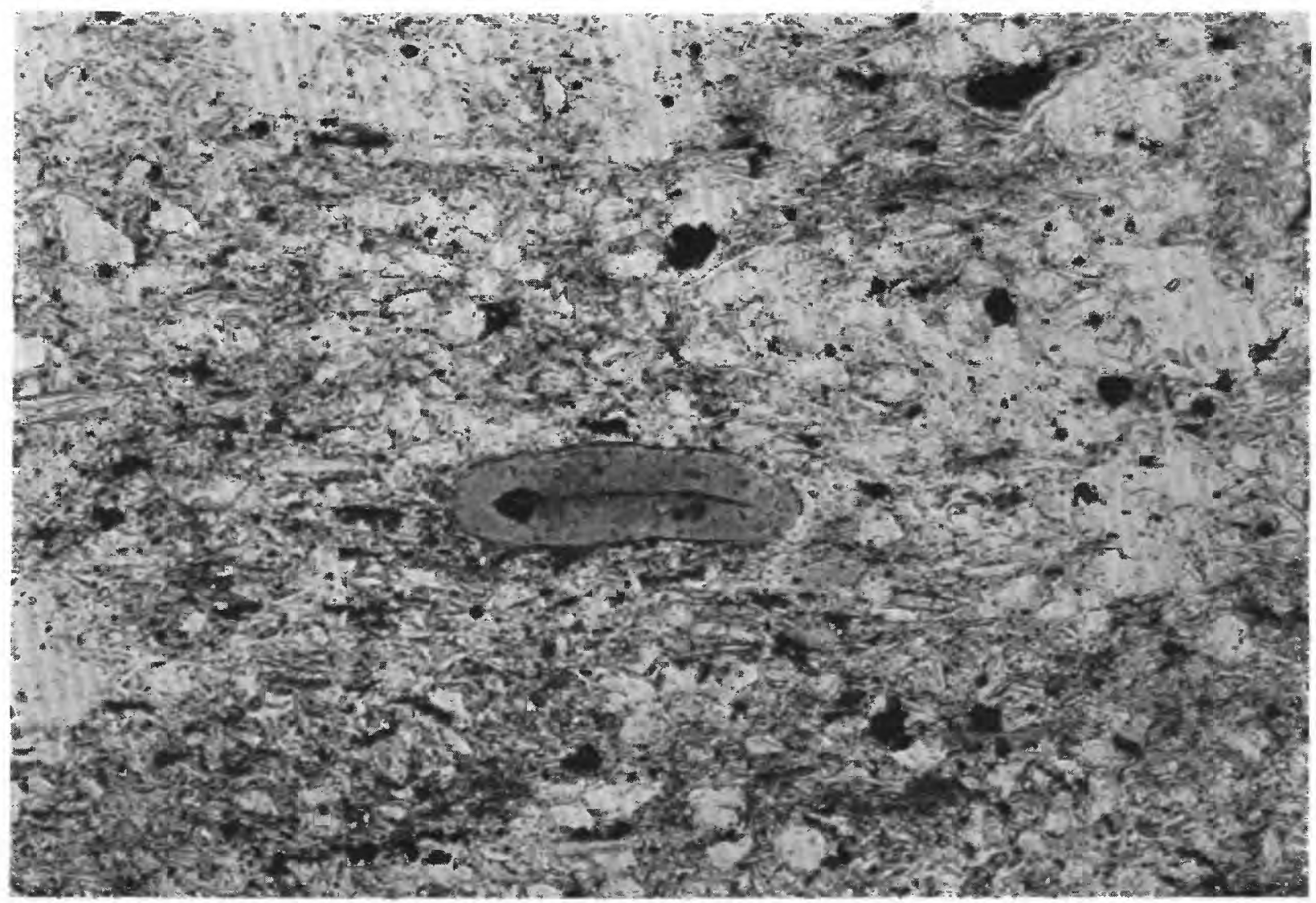

C. PHOTOMICROGRAPH OF A TASMANITES SPORE IN GRAY CLAYSTONE OF THE UPPER UNIT OF THE DOWELLTOWN MEMBER OF THE CHATTANOOGA SHALE

The matrix consists chiefly of fine particles of quartz, mica, and clay. Some of the black grains are pyrite. From a diamond-drill core, locality $93 . \quad \times 300$. 


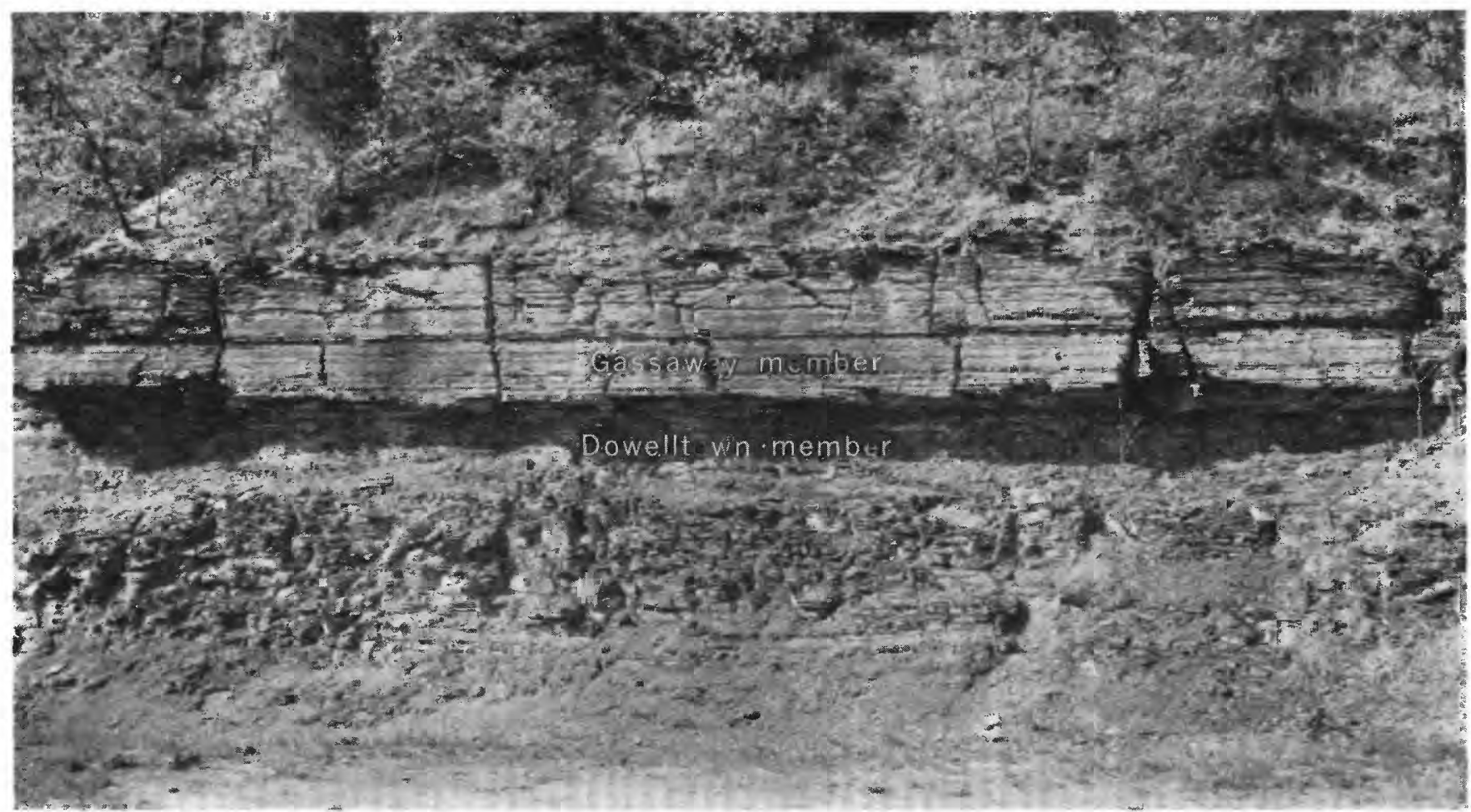

A. MASSIVE BLACK SHALE OF THE GASSAWAY MEMBER OF THE CHATTANOOGA SHALE OVERHANGING THE SHALE OF THE DOWELLTOWN MEMBER The shale of both members looks much alike when fresh, but, as shown in the photograph, the lower member yields more readily to weathering. Locality 204.1952.

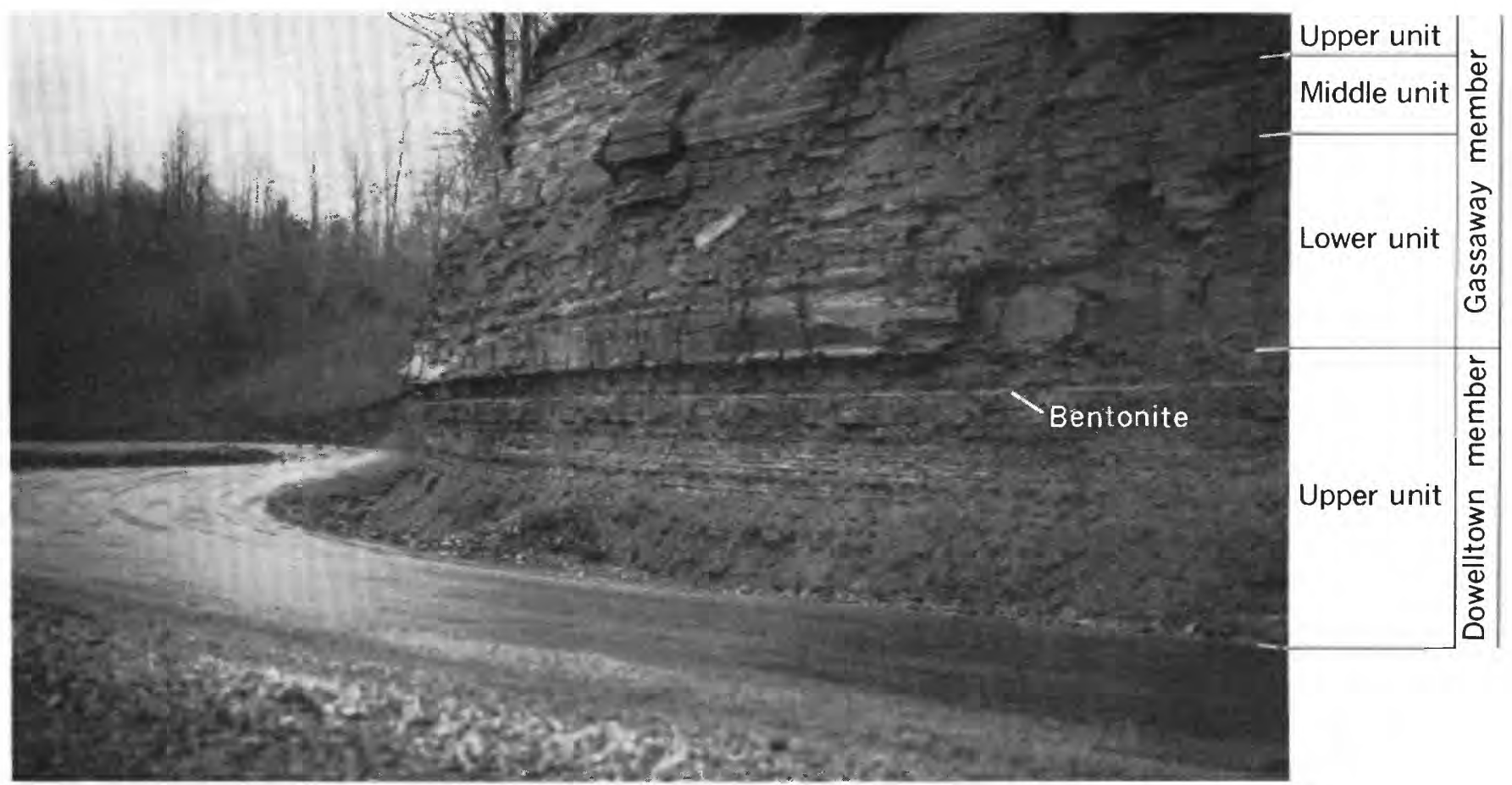

B. CHARACTERISTIC OUTCROP OF THE CHATTANOOGA SHALE IN DEKALB COUNTY, TENN,

Below the overhanging ledge of the Gassaway member are the less resistant beds of the upper unit of the Dowelltown member, which consist of aiternating gray claystone and black shale. Locality 70.1953 . 
GEOLOGICAL SURVEY

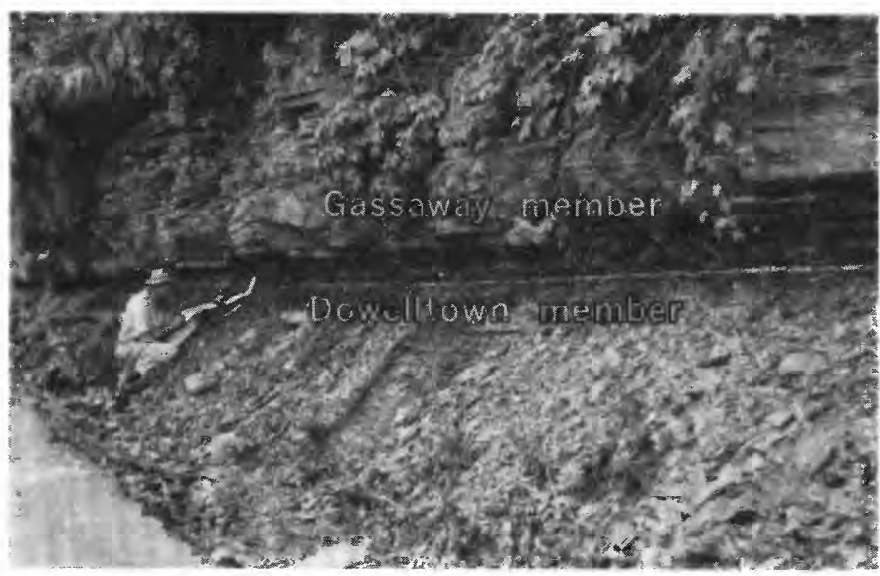

A. MASSIVE SHALE OF THE GASSAWAY MEMBER OVERHANGING THE WEAKER BEDS OF UPPER UNIT OF THE DOWELLTOWN MEMBER OF THE CHATTANOOGA SHALE

The contact is near the middle of the man's hat. The light-colored band, which is about 0.6 foot below the overhang, is the Center Hill bentonite bed. Locality 95 . 1952.

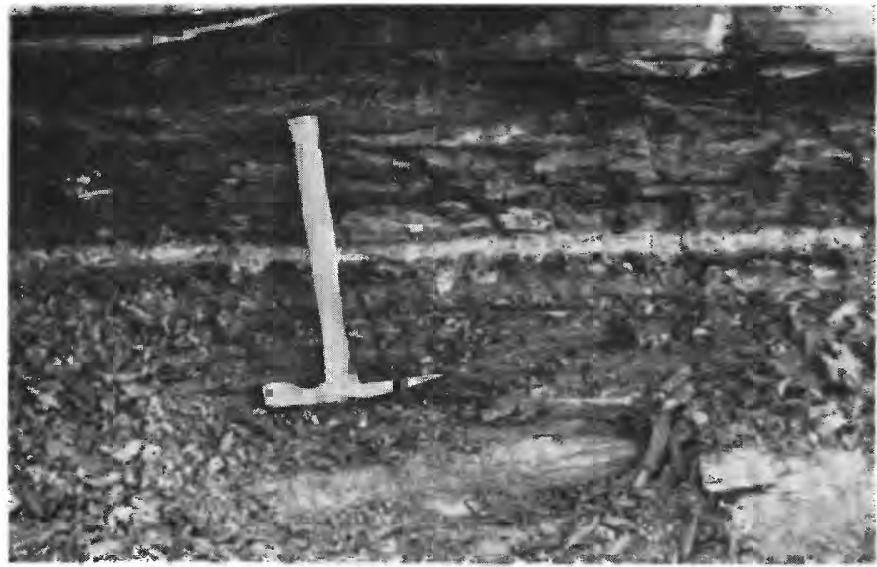

C. CENTER HILL BENTONITE BED IN UPPER UNIT OF THE DOWELLTOWN OF THE CHATTANOOGA SHALE

The bentonite is the light hand near the middle of the hammer handle and is here about 0.6 foot below the base of the overhanging Gassaway member. Locality 95 . 1952.
PROFESSIONAL PAPER 357 PLATE 9

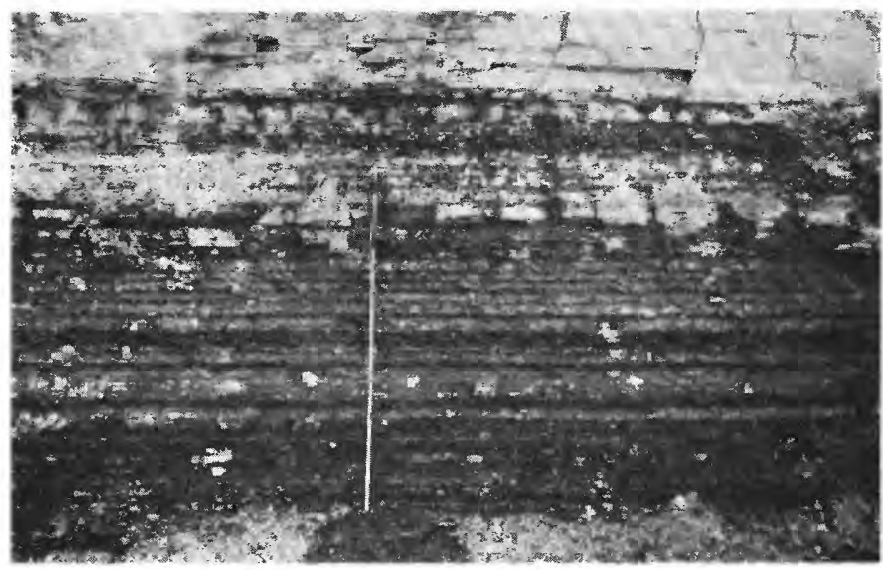

$B$. GRAY CLAYSTONE AND BLACK SHALE BEDS OF UPPER UNIT OF THE DOWELLTOWN MEMBER OF THE CHATTANOOGA SHALE

Note that black shale is more abundant in the upper and lower parts of the unit Moisture and light conditions caused some black beds to appear white, especially in the upper part of the picture. Top of 6-foot rule is at the Center Hill bentonit bed, which is here 1.15 feet below top of the Dowelltown member. Massive black shale, here appearing light colored, is at top of picture. Locality 70.1950.

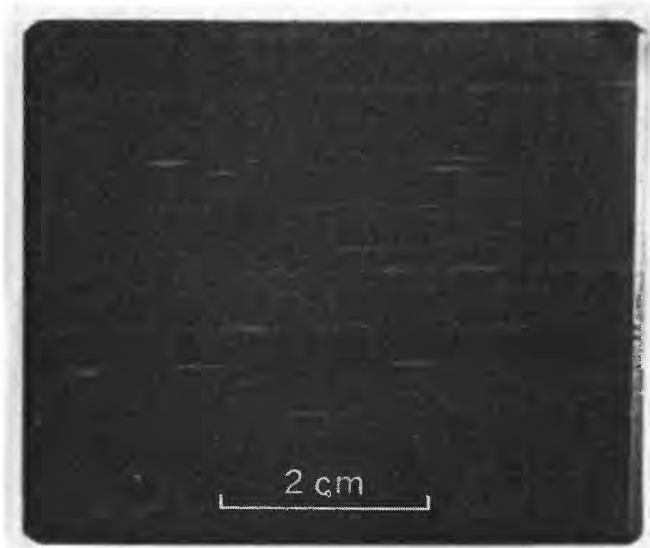

D. MINUTE LAMINAE OF SILTSTONE IN SAWED BLOCK OF MASSIVE BLACK SHALE OF THE GASSAWAY MEMBEF

Specimen is from the adit (loc. 79) near east approach to abandoned Sligo bridge, De Kalb County, Tenn. 
central Tennessee is largely post-Kinderhookian, or in other words almost if not entirely of Osagian age. In addition, it is highly probable that southward in Alabama it may be of a younger age, Warsaw and possibly even St. Louis.

Stockdale (1939) apparently held similar views on the age and stratigraphic relations of the Chattanooga shale.

Campbell (1946, p. 883-848) called attention to the small brachiopod Schizobolus in the lowest beds of the black shale sequence that Pohl (1930) had named the Trousdale shale; he also identified the beds in Sumner and Trousdale Counties, Tenn., and Allen County, Ky. He assigned them to the Middle Devonian. Campbell divided the rest of the black shale into his Dowelltown formation, which he considered to be of Late Devonian age, and his Gassaway formation of Mississippian age. He based his age determinations on the presence of Barroisella n. sp. and Spathiocaris in the Dowelltown and of Lingula melie in the Gassaway. $\mathrm{He}$ also attempted to correlate by lithologic characteristics the different parts of the formation in Tennessee with the units he had recognized and dated in Kentucky and Indiana.

In the years just preceding our investigations a Mississippian age was generally accepted for much or all of the Chattanooga shale in Tennessee and nearby areas, as illustrated by the report on the "Correlation of the Mississippian formations of North America" (Weller and others, 1948, especially chart 5, cols. 86-89 and 92-97).

\section{FOSSILS}

PLANT MATTER

Many plant and animal fossils are present in the shale, but few are of types that have been widely used for age determinations. Plant remains are much the most abundant and are responsible for the dark color of the shale, but most of them are so degraded and in such minute fragments that they are best referred to simply as carbonaceous matter. Larger plant fossils are occasionally seen on freshly exposed bedding planes and are unmistakable. J. M. Schopf of the U.S. Geological Survey (written communication, 1954) identified some of them as Callixylon, which came to the sea as driftwood from land areas. In cross section the large plant remains appear as thin shiny black layers, commonly only 1 to $2 \mathrm{~mm}$ thick but in places as much as 10 to $20 \mathrm{~mm}$ thick; they have been erroneously referred to as bitumen. Schopf (written communication) examined these layers and stated that they are chiefly vitrain, the shiny constituent of coal.
An unusually thick layer of plant matter in an outcrop near Nashville (loc. 203B) is half an inch or more thick and several feet long. When the overlying beds were removed, the coaly layer was clearly recognizable as a matted mass of stems and other plant parts. Breger and Schopf (1955) reported that some of the material in this layer is Callixylon and that the bed corresponds in rank to high-volatile A bituminous coal (see table 9, page 47 , for analyses).

Schopf (written communication, 1953) identified, in samples from various outcrops, parts of the free-float. ing marine algae Foerstia and Protosalvinia, both of which are known only from rocks of Devonian age. He also recognized parts of the algoid plant Phototaxites and several varieties of spores or sporelike objects which he assigned to the land-plant genus Tasmanites. Locally some spores can be seen with the naked eye, but more commonly they are seen in thin sections prepared for microscopic study (pl. $5 C$ ). A single specimen from the Sligo adit (loc. 79) was provisionally identified by Schopf as similar to Duisbergia mirabilis, previously reported only from beds of Middle Devonian age.

The abundant plant debris, which is mainly macerated and unidentifiable fragments, constitutes about 20 percent of the black shale by weight and is the probable cause of the toughness of the shale, for it fills all the interstices, cloaks the minute mineral grains, and binds them all tightly together. The gray claystone beds of the formation obviously have less plant matter than the black shale, but thin sections show that they contain scattered particles of plant matter (pl. $5 C^{\prime}$ ).

\section{CONODONTS}

Conodonts of many kinds are common in the shale but are so small that they are barely visible to the naked eye. Quantitatively they constitute only a small fraction of 1 percent of the rock. They are phosphatic, being composed of the fluorine-bearing mineral dahllite (Hass and Lindberg, 1946). Conodonts are the unknown part of an undetermined type of marine animal that is known to have been bilaterally symmetrical. These fossils and their stratigraphic relations are discussed in detail in a separate report by Hass (1956), and the following discussion of them is based entirely on that work.

Diagnostic conodonts are common in the basal sandstone, but otherwise are relatively scarce in the Dowelltown member. Those that are present suggest that most of the Dowelltown member should be correlated with the lower part of the Upper Devonian black shale of Ohio (Hass, 1953; 1956).

Two conodont species typical of the Dowelltown member are Palmatolepis unicornis Miller and Young- 
quist, and P. subrecta Miller and Youngquist. P. unicornis is most characteristic of the few feet of the lower unit of the Dowelltown member, just above the basal sandstone, but ranges throughout most of the member; $P$. subrecta ranges throughout the Dowelltown and into the basal beds of the overlying Gassaway member. $P$. subrecta has been found in collections from the Upper Devonian Dunkirk shale of New York, the Olentangy shale of Ohio, and a faunal zone of the middle division of the Arkansas novaculite of Arkansas and Oklahoma.

The Gassaway member contains two distinct conodont faunas. The older of these ranges throughout the member, with the exception of the topmost few feet, and contains the following species, which are considered to be characteristic of the Upper Devonian:

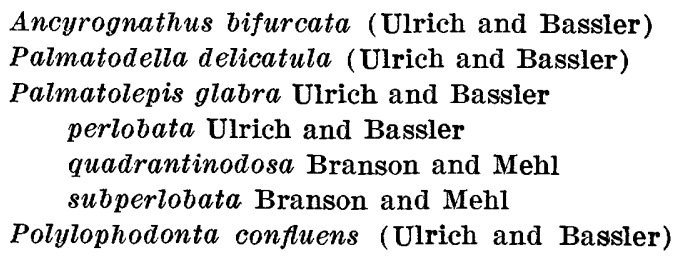

Some or all of these species are present in the lower part of the Ohio shale (Huron member) in Ohio and Kentucky; the Blackiston formation of Campbell (1946) in Indiana and Kentucky; the Chattanooga shale near Huntsville, Ala., from which Holmes (1928) obtained the conodonts she described; and the so-called Hardin sandstone at Mount Pleasant, Maury County, Tenn., from which Ulrich and Bassler (1926) obtained the conodonts they described. Most of these species are also known to be present in a faunal zone of the Antrim shale in Michigan; a faunal zone in the Woodford shale in Oklahoma; a faunal zone of the Chattanooga shale in northeast Oklahoma and northwest Arkansas; and a faunal zone of the middle unit of the Arkansas novaculite, a formation that crops out in the Ouachita Mountains of Arkansas and Oklahoma. Some of the above-listed conodonts have not been recognized in collections from the basal foot or two of the Gassaway member; those that do range into these lowermost beds are the ones associated with Palmatolepis subrecta, a species that ranges into the underlying Dowelltown member (Hass, 1956, p. 17).

At many localities in central Tennessee the topmost beds of the Gassaway contain scattered phosphate nodules and have a distinctive assemblage of conodonts, including Hindeodella sp. A, and Spathognathodus inornatus (Branson and Mehl). These permit a correlation with the upper part of the Ohio shale (Cleveland member) in Ohio and Kentucky, and a part of the Sanderson formation of Campbell (1946) in In- diana. These formations are also considered to be of Late Devonian age.

\section{BONES}

Single bones are occasionally seen in the shale and at one place a cluster of bones was found. Where recognized, the bones are generally exposed on vertical outcrop faces where the rock has broken along a joint plane, and they so resemble phosphate nodules a few inches in diameter that their true identity often is not realized until the typical bony structure is observed on a freshly broken piece. Few of the bones have been collected.

The one cluster of bones that was found in the black shale (loc. 36, Jackson County) was partially excavated and submitted to the U.S. National Museum for identification. This assemblage of bones is about 4 feet below the top of the Chattanooga shale and about 6 feet below the base of the Fort Payne chert. Dr. D. H. Dunkle (written communication, 1954) of the U.S. National Museum reported, after examining part of the material, that it contained a probable dermal armor complex of some member of the group of fishes that has been called the Dinichthys terrelli group. He also recognized in the collection numerous macerated bones and scales of the early ray-fin fishes Rhadinichthys antiquus (Williams) and $R$. devonicus (Clarke). He stated further concerning this material:

The Dinichthys terrelli group of arthrodiran fishes includes a uniquely distinct series of pelagic predators. Specific differentiations within the group are currently very difficult to establish but unquestioned members appear restricted to beds of Late Devonian age. They range, in western New York State $(D$. magnificus), from the "Conodont Bed" below the Genundawa limestone upward into the Rhinestreet shale; in Ohio and Kentucky (D. terrelli, intermedius and curtus) from the zone of spherical concretions near the base upward to below the top of the Ohio shale; and remains (D. missouriensis and/or rowleyi) have been found in the Grassy Creek shale of Missouri. As evidenced by clearly reworked bone fragments, etc., the latest occurrences of these arthrodires in the Ohio section, are found in the conglomeratic bases of the various sandstone channels of the Bedford and Berea formations where these have cut down into the underlying Devonian formations. This Late Devonian age determination is borne out also by the ray-finned fish remains that are known to occur only in the Rhinestreet shale of western New York State and in the Ohio shale of northern Ohio upward from the earliest horizon, which is known to me as the Schaeffer's Bridge Bone Bed on the Huron River above Milan, Huron County, Ohio.

In 1952 Dunkle collected most of the easily accessible bones from this outcrop for the U.S. National Museum. He stated that the bones are from one of the largest specimens of $D$. terrelli that has been found. Subsequent study of the collection (Dunkle, oral communication) revealed parts of the lower jaw bones of two individuals. Maher (Maher and Dunkle, 1955) found 
the remains of a pleuropterygian shark preserved in a phosphate nodule in the upper part of the Gassaway member in Clay County, Tenn.

\section{OTHER FOSSILS}

The fossils most commonly noticed in the Chattanooga shale are the prints or phosphatic shells of a linguloid brachiopod, which are fairly abundant at some outcrops and in certain beds. Unfortunately, these brachiopods have little known value in stratigraphic correlations or in age determinations. The phosphatic brachiopod Orbiculoidea is also found locally. Other brachiopod fossils have been found only rarely and, so far as known, are not of a quality or type suitable for positive specific identification and age determination.

The small brachiopod Schizobolus is sparsely present in the lower part of the formation in beds that Pohl (1930) termed the Trousdale shale. It was on the basis of this fossil that Cooper and others (1942, p. 1740) and Campbell (1946, p. 883) assigned the enclosing beds to the Middle Devonian.

L. G. Henbest (written communication) found a few poorly preserved Radiolaria in the phosphate nodules, where conditions were more favorable for their preservation. Although their remains could hardly be expected to be preserved in recognizable form in the shale, it is entirely possible that Radiolaria were continually among the planktonic population in the upper waters of the Chattanooga sea and that they contributed unidentifiable materiaI to the shale.

\section{PRESENT VIEWS ON AGE OF THE SHALE}

On the basis of an intensive study of the conodonts, Hass $(1953$; 1956) concluded that the Chattanooga shale of Tennessee and nearby areas is of Late Devonian age. Preliminary studies of the plant fossils by Schopf and of one bone collection by Dunkle supplied further evidence of a Late Devonian age. Seemingly these studies of widely different types of fossils have settled the long-standing controversy as to the age of the shale.

Locally the basal beds of the shale may be of Middle Devonian age, though that age assignment is so uncertain that all those beds are here provisionally assigned to the Late Devonian. In a later section of this report it is shown (p. 64) that in a few places a discontinuous bed of black shale in the Maury formation may be virtually indistinguishable from black shale of the Chattanooga but is Mississippian in age. Otherwise, all the Chattanooga shale in central Tennessee and adjacent parts of adjoining States is of Late Devonian age.

\section{STRATIGRAPHY OF THE CHATTANOOGA SHALE}

\section{CLASSIFICATIONS}

Writers have been in general agreement as to the base of the Chattanooga shale at most places because of the widespread unconformity and the conspicuous contrast between the distinctive black shale and the older underlying limestones or shales. The Hardin sandstone member in the southwestern part of the area is generally accepted as a basal unit of the Chattanooga. The position of the upper contact of the Chattanooga shale has been placed differently by several authors.

Most descriptions of the formation have noted the phosphate-bearing greenish- or bluish-gray claystone or sandstone, about 1 to 4 feet thick, immediately above the black shale; before 1900 it was commonly considered to be a part of the Chattanooga shale. Safford and Killebrew $(1900$, p. 104, 141, 143) were the first to use the name "Maury green shale" for this unit; they apparently intended that it should not be considered a part of either the underlying or overlying formation, but subsequent usage has been inconsistent. Some writers (Hayes and Ulrich, 1903, p. 2; Galloway, 1919, p. 55; Jewell, 1931, p. 37-41) have included the Maury in the Chattanooga; others (Bassler, 1932, p. 143-144; Stockdale, 1939, p. 49-51; Miser, 1921, p. 24; Campbell, 1946 , p. 885-887) have considered the Maury either a separate formation or the basal member of the overlying formation.

Galloway (1919, p. 55-56) and Jewell (1931, p. 3741) further considered the Chattanooga to have three widespread subdivisions: The Hardin sandstone at the base, the black shale, and the Maury green shale, or Maury glauconitic member, at the top.

The unit above the black shale that Hayes considered the Maury member of the Chattanooga shale, Swartz (1924, p. 24) described as a hard gray shale at the base of the Fort Payne chert; he proposed that it not be considered part of the Fort Payne, but be known as the Glendale shale. Like the Maury, his Glendale shale is only 2 or 3 feet thick, is between the Chattanooga shale and Fort Payne chert, and has the distinctive greenishgray hues, phosphate nodules, and glauconite. Because the names Maury and Glendale appear to be synonymous, and because Maury has priority, the name Glendale should be abandoned.

In much of the eastern part of the area here considered, the black shale sequence is interrupted by a middle unit several feet thick in which gray beds are as abundant as the black shale, or even more so. This unit has sometimes been informally called the middle gray part of the Chattanooga, and the more typical black shale parts of the formation have been termed the 
lower black and upper black parts of the formation (table 1). Some workers (for example, Klepser, as quoted by Stockdale, 1939, p. 50) have thought that these three lithologic divisions of the Chattanooga in central Tennessee can be correlated with the three-fold division of the Chattanooga in eastern Tennessee and southwestern Virginia (Swartz, 1924; 1927; 1929), but studies by Hass (1956, p. 22, 25-26) do not bear out this belief.

Mather (1920, p. 19) noted in Sumner County, Tenn., two distinct divisions in the Chattanooga shale, separated by an unconformity. He expressed the opinion that two black shale formations are present, though he did not propose names for them.

Pohl (1930) thought that the lowermost few feet of the shale in Sumner County should be separated from the two divisions of Mather, and for that lowest unit he proposed the name Trousdale shale. He considered the Trousdale to be of Genesee-Portage (Late Devonian) age, and the two overlying divisions of Mather to be of Mississippian age. Later Cooper and others (1942) and Campbell (1946) assigned the Trousdale shale to the Middle Devonian.

Campbell (1946, p. 881-884) proposed that the Chattanooga shale of Tennessee be divided into three formations-the Trousdale formation of Middle Devonian age, the Dowelltown formation of Late Devonian age, and the Gassaway formation of Mississippian age. He traced several smaller units of the Chattanooga shale and parts of the overlying Maury formation and their correlatives over large areas and proposed formal geographic names for them. In this report Campbell's terms Dowelltown and Gassaway have been accepted, the former with some modification. Table 2 compares Campbell's usage and age assignment with those of this report.

TABLE 2.-Comparison of stratigraphic nomenclature and age assignments of Campbell and of this report

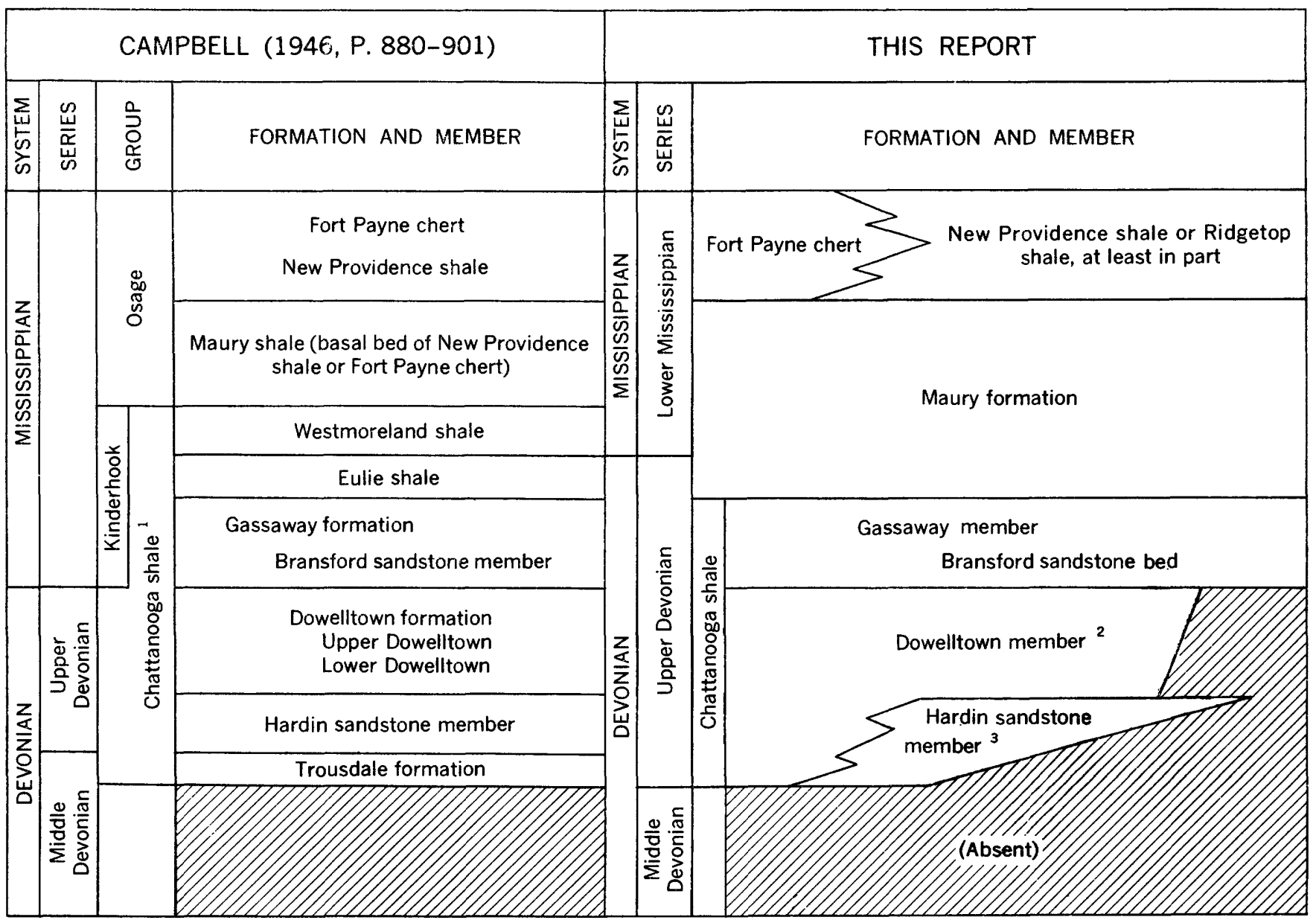

1 Campbell assigned no speciflc rank to the Chattanooga shale; he treated it as superior to a formation but did not indicate its relation to a group.

2 Includes Trousdale shale of Pohl (Trousdale formation of Campbell).

3 Present only in southwestern Tennessee and northwestern Alabama; presumed to be of Late Devonian age. 
With the exception of the Trousdale formation and the Hardin sandstone member, all the subdivisions of the Chattanooga shale shown in table 2 as used by Campbell were also proposed by Campbell. In this report the beds identified as Trousdale by Pohl and Campbell are considered to be a part of the Dowelltown member of Late Devonian age.

Rather than split into two formations the thin sequence of similar rocks that for so long has been considered one formation, the name Chattanooga shale is retained as the formation name for much the same rocks for which it has been used for over half a century. Campbell's terms, Dowelltown and Gassaway, are redefined as member names for the units to which he apparently intended to apply them. Along most of the eastern edge of the Nashville Basin the Dowelltown can be readily subdivided into two units and the Gassaway into three. In some areas only the Gassaway member is present, in some others both are present, but nowhere is only the Dowelltown known to be present. Studies of the conodonts have led to the conclusion that the Gassaway and Dowelltown members are of Late Devonian age. For the most part, the two members can be recognized by their physical characteristics along much of the northern and eastern edges of the Nashville Basin, in parts of the Sequatchie Valley, and in the cuttings of oil test wells in the intervening Eastern Highland Rim and Cumberland Plateau. Where the distinctive beds of the upper part of the Dowelltown are absent, the two members can be differentiated with certainty only by study of their conodonts.

Campbell's descriptions of his Dowelltown and Gassaway formations at his type localities overlap and include a few feet of the same strata in both units (Hass, 1956, p. 13-16). After Campbell did his work, several nearby deep highway cuts exposed complete sections of the entire Chattanooga shale beneath as much as 50 feet of overburden, and these sections leave no doubt as to the real succession of beds within the formation.

The Hardin sandstone of Safford and Killebrew (1900), considered by Campbell to be a basal member of his Dowelltown formation, is here treated as a member of the Chattanooga shale. The Hardin grades upward into the Dowelltown member and is restricted, geographically, to the vicinity of Hardin, Wayne, and Perry Counties, Tenn. (fig. 6).

The Bransford sandstone member of Campbell is an easily recognized sandstone, commonly 3 inches or less thick, at the base of the Gassaway member along the northwestern edge of the Nashville Basin. It is referred to in this report as the Bransford sandstone bed.
In the early part of the work for this report, the several stratigraphic units were referred to by descriptive lithologic terms. These informal terms were used in various administrative reports, field conferences, and correspondence and have consequently appeared in several reports by other workers. After 1952 the more formal terms were used (table 1,p.6).

\section{SUGGESTED STANDARD LOCALTTY}

Two of the best and most accessible of the new exposures of Chattanooga shale are along the approaches to the new Sligo bridge over the recently impounded waters of Center Hill Reservoir, in DeKalb County, about 6 and 7 miles east of the courthouse at Smithville along Tennessee Route 26 (loc. 76, 82). These excellent exposures are only about 11 and 18 miles east of the Dowelltown and Gassaway type localities, and the eastern one (loc. 76) is here used as a standard locality in redefining the Doselltown and the Gassaway as members of the Chattanooga. At the eastern locality the formation is well exposed in clear-cut association with the overlying and underlying rocks, and all the characteristic features of Campbell's localities are present. This Sligo outcrop is diagrammed in figure 5.

After completion of fieldwork, the entire Chattanooga and Maury sequence was well exposed 5.8 miles west of Smithville in an unusually deep cut for a new highway leading off the Highland Rim. This outcrop is only about a mile from the type locality of Campbell's Dowelltown formation and shows virtually the same stratigraphic section as the one at our standard locality. If it had been exposed earlier, it would very likely have been chosen as the standard locality. Other equally good exposures show the same stratigraphic section and would have been excellent standard localities. The Sligo one was chosen because of its proximity to Campbell's localities, and because it shows promise of remaining well exposed and accessible for a long time.

\section{BASAL SANDSTONE}

At most outcrops a basal bed of sandstone is about 0.1 foot thick, or less, but locally is thicker and exceptionally is as much as 3 feet thick, especially along the Western Highland Rim and in the western valley of the Tennessee River. It commonly contains abundant detrital fragments of quartz, chert, conodonts, phosphate, shells, and bones. The sandstone is a typical basal conglomerate in miniature, containing the coarser fragments of the material that was on the nearby land surface at the time of inundation by the sea, together with fragments of animals that inhabitated the sea. In a few places a thin bed of black shale 


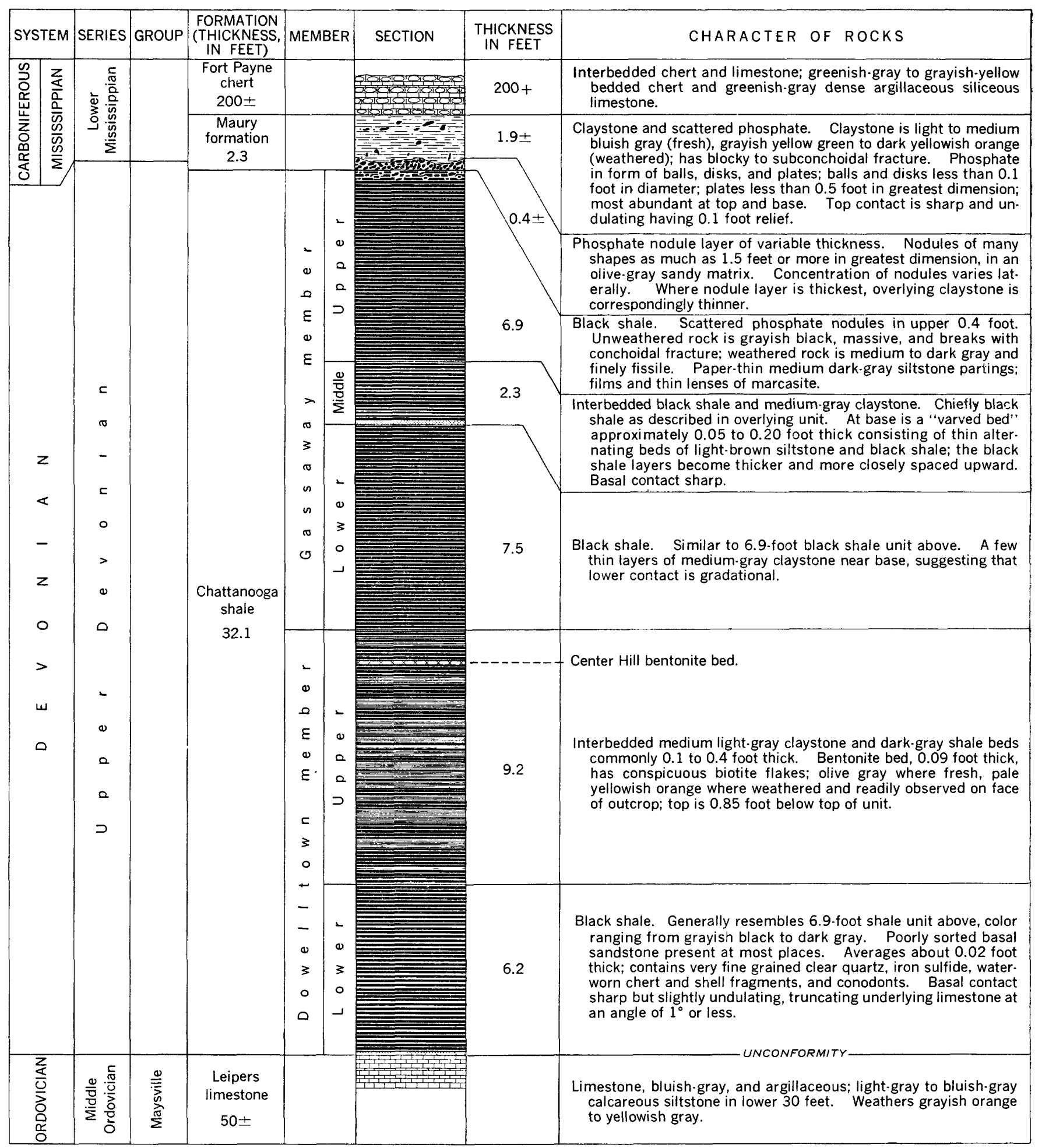

FIGURe 5.-Standard section of the Dowelltown and Gassaway members of the Chattanooga shale. Vertical cut along east approach to Sligo bridge on State Route 26 (loc. 76), about 7 miles east of Smithville, DeKalb County, Tenn. 
is enclosed within the sandstone or lies beneath it, a condition that is referred to in the later discussion of the origin of the shale (p. 53).

Three local but striking facies variations in the composition of the sandstone in Tennessee are noteworthy. In each case the variation results from special conditions that existed on the pre-Chattanooga land surface at the time it was submerged.

One of these is in the Flynn Creek cryptoexplosive area. Here the strongly shattered and even pulverized limestones were locally reworked, probably into low places on a somewhat more uneven surface than existed generally throughout the region. These local accumulations, reported to be as much as 10 or 20 feet thick, have been referred to by Wilson and Born (1936, p. 821-822) as "bedded breccia" and by Conrad and others $(1957$, p. 16) as a "fresh-water" limestone. The discovery by Hass (see p. 11) of the lower Upper Devonian conodonts in this limestone indicates that it was deposited at the beginning of Chattanooga time in a marine environment. In this unusual situation, the most available material that could be reworked into a basal sandstone was the shattered limestone. The result is a facies of the basal sandstone that, so far as we know, is unique in the formation.

Another unusual type of the basal sandstone is close to the Jackson-Clay County line, along the road that follows Hudson Creek, $41 / 4$ miles northwest of the community of North Springs in Jackson County and 33/4 miles southeast of Red Boiling Springs, which is in Macon County (loc. 210). Here the Chattanooga shale lies with an angular unconformity of about 5 degrees on a few feet of calcareous shale and quartzitic sandstone. Differential erosion of these strata has produced an irregular surface having a foot or more of relief. The quartzitic sandstone, which forms a miniature cuesta, has yielded many waterworn slabs as much as 6 inches in length. These slabs are embedded in a coarse sandstone as much as a foot or more thick. Obviously the low parts of this surface were gathering places for the coarse detritus, much of which is obviously of very local origin. Of additional interest at this place is the presence of two layers of black shale, each about half an inch thick, within the gravelly sandstone.

The third unusual type of basal sandstone is widespread in the Swan Creek phosphate field of Lewis and Hickman Counties and in nearby parts of Perry and Maury Counties. Here an unusually thick sandstone at the base of either the thin Chattanooga shale or, where that is absent, at the base of the Maury formation contains a considerable percentage of phosphate. This unit, which is 1 to 2 feet thick, was once mined as "blue phosphate." It has been incorrectly considered cor- relative with the Hardin sandstone member. The "blue phosphate" is a coarse basal sandstone consisting largely of reworked residual phosphate from the Leipers limestone. The phosphate is in the form of bluishblack ovules and phosphatized fragments of fossils from the Leipers. Smith and Whitlatch $(1940$, p. 301310) described the phosphate more fully and summarized the theories of previous writers regarding its origin.

At some places the sandstone is absent, and massive black shale of the Chattanooga rests directly on the underlying rock, though at most places diligent search reveals small separated patches of the sandstone.

The age of the sandstone ranges from earliest Late Devonian to earliest Mississippian, for the encroaching sea reached different areas at widely different times. Where the Dowelltown member is absent and some part of the Gassaway member is the lowest shale present, the sandstone is of Gassaway age. At places where the entire Chattanooga shale is absent, a similar sandstone at the base of the Maury formation is presumed by us to be of very late Devonian or of Early Mississippian age, though nowhere has Hass found conodonts in the sandstone younger than those characteristic of the Gassaway member of the Chattanooga shale. Most of the conodonts in the basal sandstone are fragments, but Hass identified a sufficient number to determine that at most places the sandstone is closely related in age to the beds that lie immediately above it.

This range in age of the basal sandstone has contributed greatly to the long-standing disagreements over the age of the Chattanooga shale, for in the vicinity of Mount Pleasant, Tenn., where Chattanooga shale is absent and the sandstone is at the base of the Maury formation, it has supplied many of the fossils that Ulrich and Bassler (see Bassler, 1932, p. 137) used to "prove" the Mississippian age of the Chattanooga shale. In the Mount Pleasant area, however, Hass identified a number of conodonts in this sandstone and assigned its age to Late Devonian, or Gassaway.

\section{HARDIN SANDSTONE MEMBER}

The name Hardin sandstone was used by Safford and Killebrew $(1900$, p. 104, 136, 137) for a fine-grained sandstone at the base of the black shale in much of Hardin, Wayne, and Perry Counties and in parts of some of the nearby counties. The unit was named for the county, but no type section was designated. Safford and Killebrew treated it as a separate formation but stated there were reasons for considering the Hardin as part of the Chattanooga shale. Subsequently it has commonly been considered a member of the Chattanooga. 


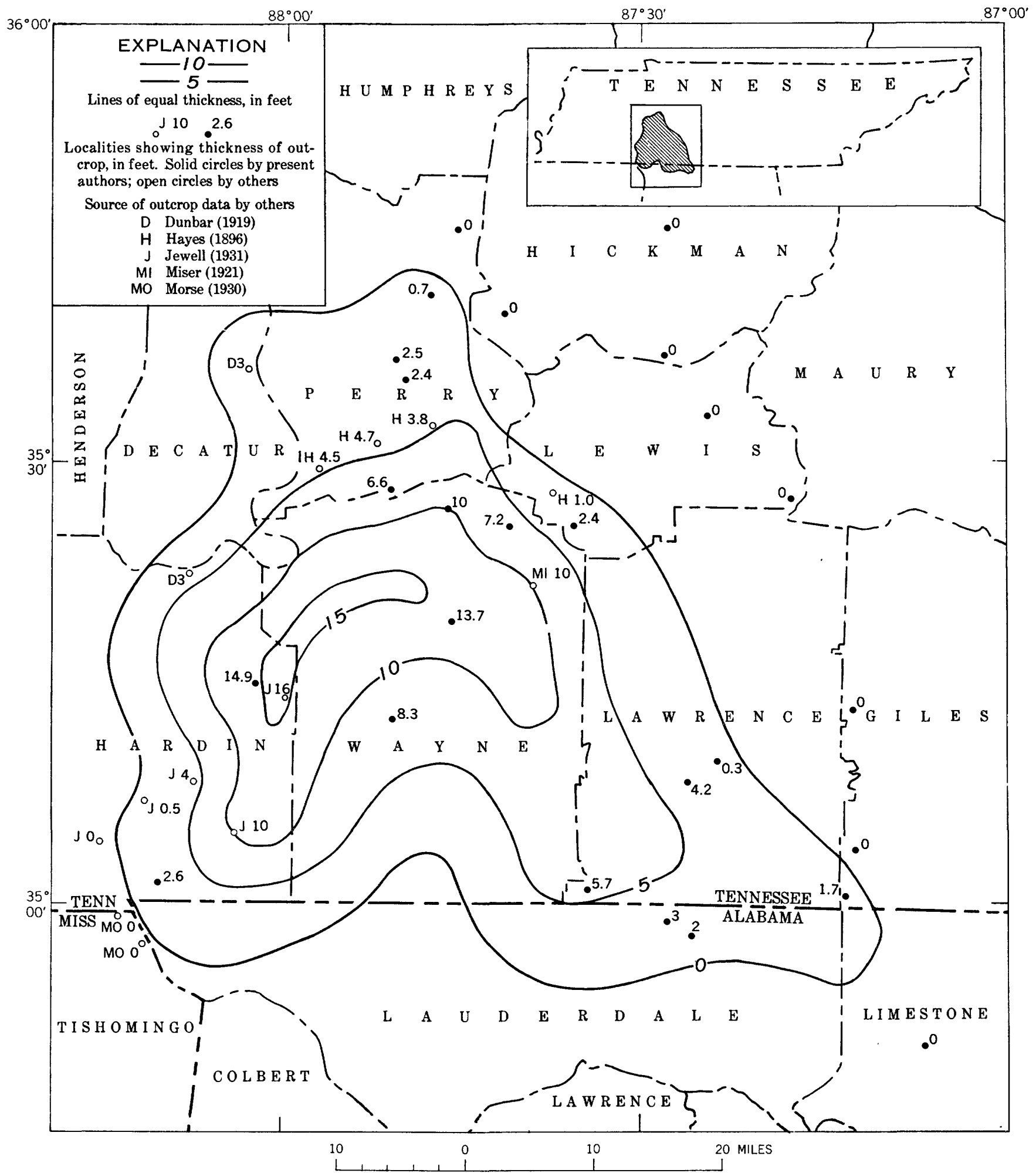

FIGURn 6.-Thickness and distribution of the Hardin sandstone member of the Chattanooga shale. 
The sandstone is massive and is so fine grained that much of it could equally well be termed a siltstone. It is somewhat phosphatic, contains pyrite spherulites and concretions as much as 0.5 foot in diameter, and is very light to dark gray when fresh. When weathered it commonly has colors close to grayish yellow (5 Y 8/4). At most places the rock is so firmly cemented with silica that it breaks across the quartz grains; at some localities it has a calcareous cement. The sandstone is slightly coarser at the base, where it has a few scattered sand grains as much as $2 \mathrm{~mm}$ in diameter and a few scattered phosphate nodules. Fossils are scarce.

The distribution and thickness of the Hardin sandstone member are shown in figure 6.

The thickest known exposures of the Hardin sandstone member are near Olivehill in Hardin County where Dunbar (1919, p. 91, 119-120) and Jewell (1931, p. 39) reported it to be 16 feet thick. A 15-foot ledge of the sandstone crops out along U.S. Highway 64 at the east edge of Olivehill (loc. 238).

At Olivehill (loc. 239) an unbroken sequence shows the sandstone of the Hardin member grading upward through a 12-foot interval of alternating beds of fine sandstone and shale into the black shale of the Dowelltown member. Such an upward gradation of the sandstone into the shale is common in the general area of Hardin County. The Olivehill exposure is described in the following section.

Section near stone church at Olivehill, Tenn.

Maury formation:

Siltstone having glauconite, sulfide nodules, and

abundant phosphate; poorly exposed; about_......

Chattanooga shale:

Gassaway member:

Shale, black; weathered and partially concealed ; about

Dowelltown member:

Shale, medium-gray to dark-gray; some interbeds of very fine sandstone or siltstone; contains Palmatolepis unicornis

Shale, black to dark-gray ; contains Palmatolepis unicornis

Shale, dark-gray; alternates with siltstone and very fine sandstone

Hardin sandstone member:

Sandstone and siltstone, gray and brown; massive; exposed in road ditch

Sandstone, poorly exposed near creek; base of unit not exposed; about

Total Chattanooga shale, about

Feet

1

12.

2.7

10.

48.0

The presence of the conodont Palmatolepis unicornis indicates that the black shale into which the sandstone grades belongs to the Dowelltown member.
At some places, as in southwestern Lawrence County, the Hardin sandstone member is separated by a knifesharp contact from overlying black shale of Gassaway age. In central and northern Wayne County black shale is absent and the Hardin is overlain directly by the Maury formation, as illustrated by the following section of an outcrop half a mile north of Waynesboro on the west side of Tennessee Route 13 (loc. 243).

Section half a mile north of Waynesboro, Tenn.

Fort Payne chert and Ridgetop(?) shale. Feet Maury formation :

Siltstone; various shades of orange and brown; nonglauconitic at top, but increasingly glauconitic toward base, where it is abundant in lowest 0.1 foot

Siltstone; various shades of gray; glauconite more abundant toward base; laminated. Lowest 0.3 foot contains many phosphate nodules and the following conodonts indicative of a Kinderhook age: Gnathodus sp. B, G. sp. fragments, Spathognathodus aciedentatus, Pseudopolygnathus prima, Siphonodella sp. fragments, Polygnathus communis, $P$. inornata

Total Maury formation

Chattanooga shale:

Hardin sandstone member :

Sandstone, light-gray, massive; very fine grained at top, but a somewhat coarser below; basal contact somewhat undulating; about

Limestone.

An excellent exposure of the Hardin sandstone member is at locality 241 in Wayne County, where it is exposed for about a quarter of a mile along a country road that follows Indian Creek. Here 8 feet of sandstone is overlain abruptly by about 8.5 feet of poorly exposed Chattanooga shale, which in turn is overlain by about 2 feet of the Maury formation having olivegray claystone in its lower half and glauconite and phosphate nodules in its upper half.

Campbell (1946, p. 892-894) summarized the views of several previous workers regarding the Hardin sandstone member and its lateral equivalents; he accepted the earlier views of Hayes $(1896$, p. 521), Bassler $(1932$, p. 139), and Hayes and Ulrich (1903, p. 2) that it merges laterally to the north into a shaley phosphate that is present at the base of the "blue phosphate" at many places in Perry County and in the Swan Creek phosphate area of Lewis and Hickman Counties. Although we have not studied the phosphate area in as much detail as did Hayes, we are strongly of the opinion that the Hardin does not merge laterally into the "blue phosphate" because at no place did we observe a lateral merging and because the Hardin appears to be of early Dowelltown age whereas the "blue phosphate" 
of upper Swan Creek is of late Gassaway or possibly even of Maury age. The "blue phosphate" is a basal conglomerate or sandstone of whatever part of the Chattanooga-Maury sequence was first deposited on a land surface strewn with residual phosphate.

Our investigations confirmed Campbell's opinion $(1946$, p. 894) that the thin sandstone at the base of the Chattanooga shale throughout the area should not be considered the Hardin sandstone member, as has been done by some writers (for example, Galloway, 1919, p. 55; Bassler, 1932, p. 138-139). The Hardin is an abnormally thick local phase of the basal sandstone, and the name should be reserved for the distinctive quartzitic and massive very fine sandstone or siltstone of the area in and near Hardin and Wayne Counties (fig. 6). However, the thin basal sandstone or conglomerate, present nearly everywhere at the base of the Chattanooga shale, is quite variable in composition and ranges in age as much as the next overlying material. The Hardin grades upward, locally, only into the Dowelltown; the ubiquitous basal sandstone grades upward into whatever unit overlies it.

No conodonts have been found in the Hardin sandstone member but, because the Hardin grades upward at some places into the lower part of the Dowelltown member, it is considered to be of early Late Devonian age. It is possible, however, that a part of the Hardin sandstone member may be slightly older.

Complete exposures of the Hardin sandstone member and the overlying beds of the Chattanooga shale and Maury formation are not common, so interpretation of the relations of the Hardin sandstone member to the overlying beds is not easy. The following interpretation is, therefore, based on fragmentary evidence and is not as well documented as could be wished.

In at least part of Hardin County (for example, loc. 239) sedimentation obviously was more or less continuous from the Hardin sandstone member into the overlying Dowelltown member, and it is probable that a continuous sequence existed elsewhere, but at most places no transitional sequence is now present. Sedimentation was interrupted, probably at the end of Dowelltown time, and the muds and gradational beds of the Dowelltown member, and perhaps some of the Hardin sandstone member, were removed before muds. of the Gassaway were deposited. In many of these places, black shale of the Gassaway member overlies the Hardin sandstone member. In still other places, the Gassaway beds are also missing, either because the area was not inundated during Gassaway time or because the muds were removed by a post-Gassaway pre-Maury erosion interval.

\section{DOWELLTOWN MEMBER}

IITHOLOGIC CHARACTER

The Dowelltown member of the Chattanooga shale is lithologically most distinct along the eastern edge of the Nashville Basin. There it contains a lower unit, chiefly of black shale, and an upper unit of abundant beds of gray claystone interbedded with black shale. Because the lighter color of the upper unit contrasts with the black shale of the rest of the formation the unit has been noted frequently by previous workers and has sometimes been referred to as middle gray unit of the Chattanooga (table 1). Throughout most of the Eastern Highland Rim area and in some other areas where the gray claystone unit is present, a distinctive thin bed of bentonite near the top is most useful for identification and correlation of the beds (pls. $6 B, 8$ ).

Where the Dowelltown member has been identified but where the two lithologic units are not distinct, the member consists chiefly of dark-gray or medium-darkgray shale. Commonly this shale is less dense and massive than the black shale of the overlying Gassaway member, and in vertical exposures it breaks down more readily when weathered (pl. 6A). This undivided phase of the Dowelltown member is especially characteristic along the northern edge of the Nashville Basin from the general vicinity of the Cumberland River in Jackson County to the Nashville area, but in those places the Dowelltown member can be differentiated from the Gassaway by its lithologic character, its differential weathering, and its conodonts.

In the central part of the northern edge of the Nashville Basin the lower few feet of the Dowelltown member is composed of several layers of calcareous siltstone and black shale that Pohl (1930) defined as the Trousdale shale (p. 22). Pohl did not designate a type locality for this unit, but one of the most accessible exposures of these beds is locality 206 in Sumner County, where about 2 feet of the calcareous sandy shale is present. We do not consider the unit sufficiently distinct lithologically or of sufficient areal extent to warrant member status.

\section{EXTENT AND THICKNESS}

The Dowelltown member is consistently present along the eastern edge of the Nashville Basin as far south as Moore County, along the northern edge of the basin, and along the western edge as far south as southern Williamson County. It is also present in Kentucky, and in the northern part of the Sequatchie Valley in Tennessee (pls. 7, 8). It is not a recognizable lithologic unit near the southern edge of Tennessee or in the States farther south, though Hass (oral communication) identified conodonts of Dowelltown age 
from rock as much as 2.2 feet above the base of the Chattanooga shale at locality 230, near Menlo, Ga., and in the lower 7 feet of the exposed beds at locality 235 in northeastern Mississippi. As pointed out by Glover (1959, p. 13) in discussing the eastern part of this southern area, lithologic differences are insufficient to warrant splitting the formation into members, and the terms Dowelltown and Gassaway are useful in a time sense only.

Along much of the eastern edge of the Basin the Dowelltown member is commonly about 15 to 20 feet thick. At some places near the northeast corner of the Nashville Basin, as at localities 16, 22, and 25, the member is a single unit about 5 feet thick, or less. Along most of the northern edge of the basin the Dowelltown is about 15 to 20 feet thick. The thickness of this member differs more between nearby outcrops than does the thickness of the Gassaway member, probably because of slight irregularities on the land surface when it was inundated by the Chattanooga sea.

The diamond-drill cores taken in 1953 near Smithville, DeKalb County, at intervals of about 1 mile, show a slight thinning of both members of the Chattanooga shale toward the Nashville Basin. In the Dowelltown member this thinning amounts to about 3 feet in an eastwest distance of 15 miles (figs. 9, 10).

\section{LOWER AND UPPER CONTACIS}

Except at those places where the Hardin sandstone member underlies the Dowelltown member, the lower contact of the Dowelltown is also the basal contact of the Chattanooga shale. Commonly the position of this contact is easy to identify.

The upper contact of the Dowelltown member is the only pronounced and continuous lithologic break in the Chattanooga shale. Along much of the eastern edge of the Nashville Basin the break is fairly conspicuous in most good outcrops, but it is difficult to locate precisely because two or three thin beds of gray claystone are present in the lower half foot of the overlying Gassaway member. In that area the contact can be identified fairly consistently at the base of the lowest massive black shale bed within the doubtful interval. Below that horizon the rock is predominantly gray claystone; above, it is predominantly black shale. In most other areas the contact is fairly sharp and can be found with ease, for example, in eastern Sumner County (loc. 206) where Mather (1920, p. 19) noted a slight angular unconformity.

The contact between the Dowelltown and Gassaway members in some areas marks a diastem or slight unconformity within the Chattanooga shale, probably the result of submarine erosion or planation before the muds of the Gassaway member began to accumulate.
The best observed examples are in the Woodbury area (fig. 8), where the bentonite and associated beds appear to have been removed before Gassaway time, and at Bransford (loc. 206) where a slight angular discordance separates the two members. The thin bed of Bransford sandstone at the base of the Gassaway member at many places also suggests the presence of a slight unconformity at this position. The widespread presence of the thin Center Hill bentonite bed, however, in the upper 2 feet of the Dowelltown member is evidence against any appreciable erosion at the end of Dowelltown time. Mention has already been made (p. 28) of probable erosion of some of the beds at the end of Dowelltown time in areas where the Hardin sandstone member is present.

\section{LOWER UNIT}

General characteristics. - The lower unit of the Dowelltown member is one of the several characteristic black shale units of the Chattanooga shale, and, like those others, it emits a distinct odor of petroleum when broken. When fresh it is firm and strong and tends to break with a conchoidal fracture; when weathered it crumbles into thin wafers (pl. 10B). Scattered throughout the unit are paper-thin partings of siltstone; discontinuous thin lenses or films of sandstone; thin films, lenses, and crystals of pyrite or marcasite; and a few beds of somewhat lighter colored claystone 0.02 foot thick or less. This unit is similar to the massive black shale of the Gassaway member except that it contains more thin beds of other material, is somewhat less massive where fresh, and is slightly less radioactive (fig. 18). Petrographic examination shows that the fresh rock is minutely laminated, most of the grains being in the size range of silt and clay.

A bed of sandstone that is present at most places at the base of the Dowelltown member ranges in thickness from zero to several inches but commonly is an inch or less thick. This, in turn, rests unconformably on the older rocks, which, at most places, are of Ordovician or Silurian age.

The contact of the lower unit of the Dowelltown with the overlying gray claystone unit is somewhat gradational but can generally be located without much diffculty within half a foot or less.

Extent and thickness.-Except locally, as in the area of the Hardin sandstone member, the lower unit of the Dowelltown member is not as widely distributed as are most of the higher black shales, presumably because the Chattanooga sea did not flood as wide an area during early Dowelltown time. It is absent in much of southern Tennessee and in much of the area west of the basin. Black shale of the Dowelltown has been identified at several scattered outcrops in the region where: 
it is generally absent, but there is no basis for correlating it specifically with either unit of the Dowelltown member as they are recognized along the eastern edge of the basin.

Except near its lateral limits, the lower unit of the Dowelltown member is commonly about 5 to 9 feet thick. At a few places it is somewhat thicker, probably because of low places on the old land surface, as at locality 80 where a poor outcrop shows about 13 feet. In the Flynn Creek cryptoexplosive area the unit is as much as 170 feet thick, probably because the sea floor at that place subsided as the muds accumulated (p. 12).

\section{UPPER UNIT}

General characteristics. - The upper unit of the Dowelltown member consists of an interbedded succession of light-gray to dark-gray claystone and black shale, the gray beds predominating. Although both types of beds vary in thickness, most of the individual black and gray beds are a few inches thick. Along the central part of the Eastern Highland Rim, the gray beds are much more abundant in the middle of the unit, and the black shale beds are more abundant toward the lower and upper contacts. The gray beds are not as tough and massive as the black shale, probably because little organic matter is present to bind the particles. On weathering in vertical exposures, the unit recedes and leaves the black shale of the Gassaway member overhanging (pls. $6 B, 9 A$ ). The general appearance of this unit is shown on plate $9 B$. It is the most distinctive of the several subdivisions of the Chattanooga shale and forms a conspicuous break in an otherwise fairly uniform sequence of black shale that normally constitutes the Chattanooga shale. It is the unit that has sometimes been informally termed the middle gray unit of the Chattanooga.

This unit of abundant gray claystone is easily recognized along the eastern edge of the basin from southern Jackson County to southern Coffee County. It also crops out in southeastern Williamson County (loc. 185, also p. 63) and in parts of the Sequatchie Valley of Tennessee.

Microscopic study of thin sections of the beds of gray claystone and black shale of this unit shows that the gray beds are somewhat finer grained and more clayey than the black shale beds. The gray beds are poorly laminated and appear to consist of about 50 to 75 percent clay, 10 to 20 percent quartz, and smaller amounts of very fine mica, pyrite, calcite, and organic matter. The mineral grains are poorly sorted and their long axes show imperfect parallelism. The quartz grains are exceedingly small, ranging roughly from 0.008 to 0.065 $\mathrm{mm}$ and averaging about $0.02 \mathrm{~mm}$ in diameter. The flakey clay grains are much smaller, their lengths being typically about one-half to one-third the dimensions of the quartz grains.

The grains in the black shale that is interbedded with the claystone are somewhat better sorted than those in the gray claystone but not as well sorted as those in the more massive black shales of the Gassaway member. The quartz grains in the black layers have an average diameter of about 0.01 to $0.02 \mathrm{~mm}$. Pyrite is abundant as minute grains ranging from about 0.01 to $1.0 \mathrm{~mm}$. The lack of sorting and the somewhat random orientation of the grains in the gray beds probably explain the absence of fissility of these beds. The black shale beds in this unit are somewhat fissile when weathered but less so than those in most of the black shale of the formation.

Bentonite.-A thin bed of bentonite, discovered by Hass (1948), near the top of the Dowelltown member of the Chattanooga shale, is the most distinctive single bed in the entire formation and has been of much value in stratigraphic work. The bed commonly ranges in thickness from about 0.05 to about 0.14 foot and in most outcrops is about 0.1 foot thick. In general, the bed is slightly thicker toward the east. Wherever it was observed it is within 2 feet of the top of the Dowelltown member, and no similar bed was found elsewhere in the formation. This bentonite clearly represents a single fall of volcanic ash and is, therefore, a useful time marker. It is here designated the Center Hill bentonite bed because of its presence at all known outcrops of the Chattanooga shale that are adequately exposed near the Center Hill Reservoir in DeKalb, Putnam, and White Counties, Tenn. Its type exposure is at the proposed standard locality of the Chattanooga shale along the east approach to the Sligo bridge in DeKalb County (fig. 5).

Unweathered samples of the bentonite are light gray (N 6) but are commonly found only in new deep highway cuts, some waterfalls, and drill holes. Flakes of euhedral biotite are easily seen in the fresh material. Weathering quickly bleaches the biotite and causes the bed to be much lighter colored and faintly iron stained, so that its typical color in most road cuts after a few years' exposure is about yellowish orange (10 YR 7/6), though in some places it is even paler, approaching a very pale orange (10 YR 8/2). The bentonite bed, where more weathered, appears as a slightly recessed but conspicuous yellowish-red bed across the face of the outcrop (pl. $9 A, C$ ). Once this distinctive bed has been seen in one outcrop, it is easily recognized in others. 
Clarence S. Ross, of the U.S. Geological Survey, examined a fresh sample of the bentonite and found (Hass, 1948) that

*** all or nearly all of the material is of volcanic origin and that the groundmass consists of clay whose indices of refraction indicate that it is the potash type of bentonite. This is confirmed by chemical tests that indicate essential amounts of potash. A detailed study of material from Horseshoe Bend, on Caney Fork River, White County [locality 88, now submerged by the Center Hill Reservoir], indicates that fresh material contains about 30 percent of biotite, some as euhedral grains. Other crystal grains form about 8 percent of the whole. Of these about 49 percent are orthoclase, about 43 percent sodic plagioclase, and about 8 percent quartz. Thus the mineral composition is typically that of a volcanic rock. The clay groundmass was probably originally a glass.

*** The clay fraction resembles, and the biotite is similar to, that present in most Ordovician bentonites. *** The most weathered portion of the bed is nearly white and *** consists of kaolinitic clay, quartz, and abundant bleached biotite.

This is the youngest known deposit of the Ordovician type of bentonite (Ross, written communication, 1948).

More detailed studies were made at Pennsylvania State University (Strahl and others, 1954, p. 7-9) of samples of fresh and weathered bentonite. These indicate that the dark mica, when weathered, is bleached and altered to kaolinite.

At most outcrops of the Chattanooga shale along the east side of the Nashville Basin from southern Jackson County to central Coffee County, a distance of about 65 miles, the bentonite bed is found wherever that part of the shale sequence is exposed. ${ }^{2}$ It has also been found in the Sequatchie Valley of Tennessee and at one place in the western part of the basin (loc. 185, see p. 63) and was found by Hass and W. H. Heck (written communication, 1948) in the cuttings of several oil test wells in Putnam, White, and Van Buren Counties, on the Eastern Highland Rim. We made further checks of cuttings from wells in Warren, Grundy, Van Buren, Cumberland, Putnam, Overton, and Fentress Counties, in areas adjacent to the then known limit of distribution, and the bentonite was not observed.

The bentonite bed is generally present in an area in Tennessee of at least 4,000 square miles (pl. 7, fig. 7), but it is missing in one small area of about 100 square miles in the northern part of Cannon County. It is possible that the uppermost beds of the Dowelltown member were never deposited in this area, but it seems more likely that those beds were removed before the beginning of Gassaway time. At the nearby outcrops where the bentonite is present it is much closer to the top of the Dowelltown member than at more distant

\footnotetext{
${ }^{2}$ Hass (1948) reported the bentonite as being present still farther south near the Bedford-Lincoln County line, on the basis of an observation by Conant. Later observations indicate the bentonite is not present at that outcrop.
}

places. It is unlikely that the area was elevated above sea level just enough to permit the removal of only a few feet of the upper unit of the Dowelltown without producing an irregular erosion surface or any signs of subaerial weathering. More likely, local conditions caused the sea water to plane the area gently and transport the unconsolidated gray and black muds to nearby areas. A slight upwarp of the sea bottom would probably have sufficed to cause the removal of this material. The amount of uplift required may have been not much greater than the thickness of the missing sediments. It is possible, of course, that other local conditions caused currents or wave action strong enough for the indicated planation, though local upwarp seems to us to be the simplest explanation of the missing beds.

The presence of this bentonite bed, which is an excellent time datum, supports Hass' opinions on the age correlation of the Chattanooga shale as based on conodont studies and is strong evidence against the thesis that the black shale sequence is a time-transgressing unit that is youngest in the southern States. The stratigraphic ranges of conodont genera and species were found by Hass to be constant with reference to the Center Hill bentonite bed, an excellent confirmation of the dependability of conodonts in regional correlations.

The source of the ash is unknown, but the fairly uniform thickness that increases slightly toward the east suggests that it was at a considerable distance in an easterly direction. The uniform thickness and the purity of the bentonite over large areas suggest that the ash fell into a relatively quiet sea where no local currents prevented its accumulation and at a time when there was insufficient bottom agitation to mix it with other sediments.

In Scott County, Va., fragments of bentonite at least 0.15 foot thick were found in 1953 by Leonard D. Harris of the U.S. Geological Survey in an interval selected by Hass as a likely one in which to look for an extension of the Center Hill bentonite bed (oral communications, Hass and Harris). The Virginia bentonite bed is identical in appearance to the Center Hill bed in Tennessee, and in all probability it is part of the same ash fall.

The only other known reference to possible Late Devonian volcanic activity in the southeastern United States is by Price and Woodward (1940, p. 1992). They reported one or more thin sheets of igneous rock in the Naples shale of Clarke (1885) in southern Pendleton County, W. Va., and tentatively explained them as surface flows of Late Devonian age. It seems unlikely that the source of the ash in the Chattanooga shale was in or near Pendleton County, though no precise cor- 

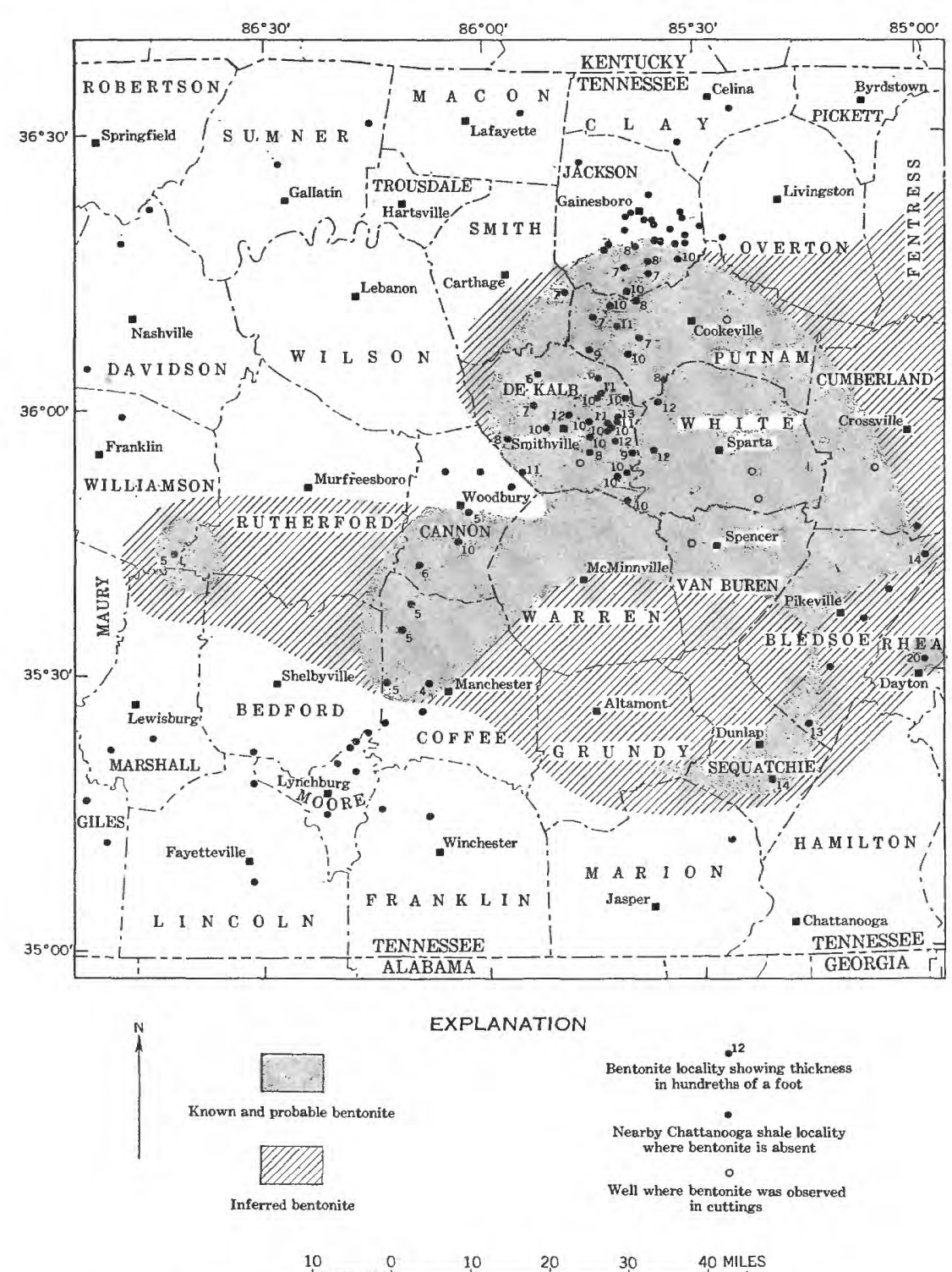

Figure 7.-Map showing distribution of the Center Hill bentonite bed.

relation of the strata in the two regions has been made.

In West Virginia a bentonite of early Middle Devonian age has been widely noted in drill cuttings and was reported (Flowers, 1952) to be almost identical with the Upper Devonian [Center Hill] bentonite in Tennessee. Flowers mentioned a probable slight eastward thickening of the bed but believed the source was not in West Virginia. Fettke (1952) stated that the same bed is present throughout much of Pennsylvania and south-central New York. Although the bentonite in West Virginia and States farther north is somewhat older than the Tennessee bentonite, all this unusual bentonite may have originated in the same area. The only suggestion as to the source of the ash is that it may be related to the volcanic activity that is recorded in rocks of Early Devonian and Mississippian(?) age in New Hampshire (Billings, 1955). If the prevailing wind direction in Devonian time was from the west, as today, the preservation of single ash falls in these areas, instead of the several that might be expected, probably resulted from fortuitous winds that carried the dust of a single explosion hundreds of miles in a southwesterly direction.

Correlation of individual beds.-Any attempt to explain the alternation of the black and gray beds of the upper unit of the Dowelltown must take account of a distinctive succession of beds beneath the bentonite. In all places where especial note was made of the underlying beds, they were found to consist, in downward succession, of about 0.1 foot of dark-gray shale, a few 
tenths of a foot of light-gray claystone, and about 0.5 foot of dark-gray shale. The constant presence of the dark-gray shale just below the bentonite over an area of several thousand square miles shows that conditions favoring black mud accumulation existed widely at the time of the ash fall. The consistent succession of beds just below the bentonite suggests further that at a given time the conditions suitable for one or the other type of deposition existed over wide areas, but that environments permitting black mud and gray mud deposition did not exist randomly and simultaneously in nearby areas. Had they so co-existed, the bentonite would lie on black shale at some places and on gray claystone at others.

Attempts to correlate other black and gray beds of the upper unit of the Dowelltown member over large areas were unsuccessful. The fact that most of the individual beds can be correlated satisfactorily only between nearby outcrops probably indicates that, during the long period of time when they were accumulating, minor uplifts, local currents, or other conditions resulted locally in decreased deposition or actual removal of some of the mud, so that many submarine diastems, most of them unrecognized, are present within the unit. At some outcrops a slight channelling or truncation can be seen in the beds, but many more such diastems probably escaped notice, either because. they were not searched for with sufficient care or because the outcrops are of too limited lateral extent.

Extent and thickness.-Along the eastern edge of the Nashville Basin the gray claystone beds, which give the upper unit of the Dowelltown member its distinctive appearance and permit its recognition, extend from central Jackson County to northern Lincoln County, a northeast-southwest distance of about 85 miles. From west to east the gray beds have been recognized from southeastern Williamson County to northern Rhea County, a distance of about 100 miles. It has sometimes been thought that these beds continue as a recognizable unit into southwestern Virginia, and Swartz (1927, p. 494) named a much thicker sequence of similar beds there the Olinger shale member of the Chattanooga shale. However, later studies by Hass (written communication to Leonard Harris, July 8, 1953) on fossils collected by Harris, H. J. Dunham, R. L. Miller, and Hass indicate that the Olinger shale member of Swartz is correlative with some part of the Gassaway member of central Tennessee and that the upper unit of the Dowelltown member of central Tennessee is correlative with part of an underlying sequence of black shale in southwestern Virginia. This correlation is strengthened by the later discovery by Harris of the bentonite bed that appears to be a continuation of the Center Hill bentonite bed (p. 31).

The upper unit of the Dowelltown member in most of its central area is about 10 feet thick (table $3, \operatorname{col} . B$, locs. 74 to 107). Near the middle of this area, however, at and near locality 99 (fig. 8) the Center Hill bentonite bed and, presumably, the overlying beds of the member are absent (fig. 8). For several miles to the north and south, the beds above the bentonite show a generally progressive thinning toward this locality (table 3, col. $E$, locs. 65 to 107 ). From these relationships it is deduced that some condition at the end of Dowelltown time, perhaps a slight uplift of the sea bottom, caused marine planation to remove the upper part of the unit. Furthermore, it seems likely that at locality 99 an additional $11 / 2$ feet of the member is missing, for at that place only $71 / 2$ feet of the upper unit is present, in contrast to about 9 feet that is present below the bentonite at nearby localities 98 and 102. Evidence is lacking as to whether the bentonite is present in outliers of the shale immediately to the west and northwest, so the distribution of the bentonite in that area is unknown.

South of the area of its maximum thickness, the upper unit of the Dowelltown member thins rapidly in southern Coffee County and disappears in the northern parts of Moore and Lincoln Counties (pls. 7, 8; fig. 8; table 3, col. $B$, locs. 107 to 114). Because the only recognizable bed of the upper member, the bentonite, is absent in most of this area of thinning, it is not possible to determine whether erosion of the upper beds is the cause of thinning, though that seems like a plausible explanation.

Northward from the area of maximum thickness, the upper unit of the Dowelltown member thins gradually through Putnam and Smith Counties and the southern part of Jackson County until it finally disappears as a recognizable unit in central Jackson County (fig. 8). However, the bentonite bed is at its customary position near the top of the unit in much of this northern area, as it is not in the southern area of thinning (table 3 , cols. $B$ and $E$, locs. 35 to 65 ). Column $F$ of table 3 shows clearly that the beds below the bentonite are the ones that are thinning. Obviously the northward thinning cannot be explained by simple erosion of the top of the unit, else the bentonite would be one of the first beds to disappear. The cause of this condition is not known, but it seems probable that the lower gray beds of the central area grade northward into black shale of the lower unit. In other words, graybed conditions were not as widespread at the beginning of upper Dowelltown time as at the end. An alternative explanation, which seems less likely, is that one or more 


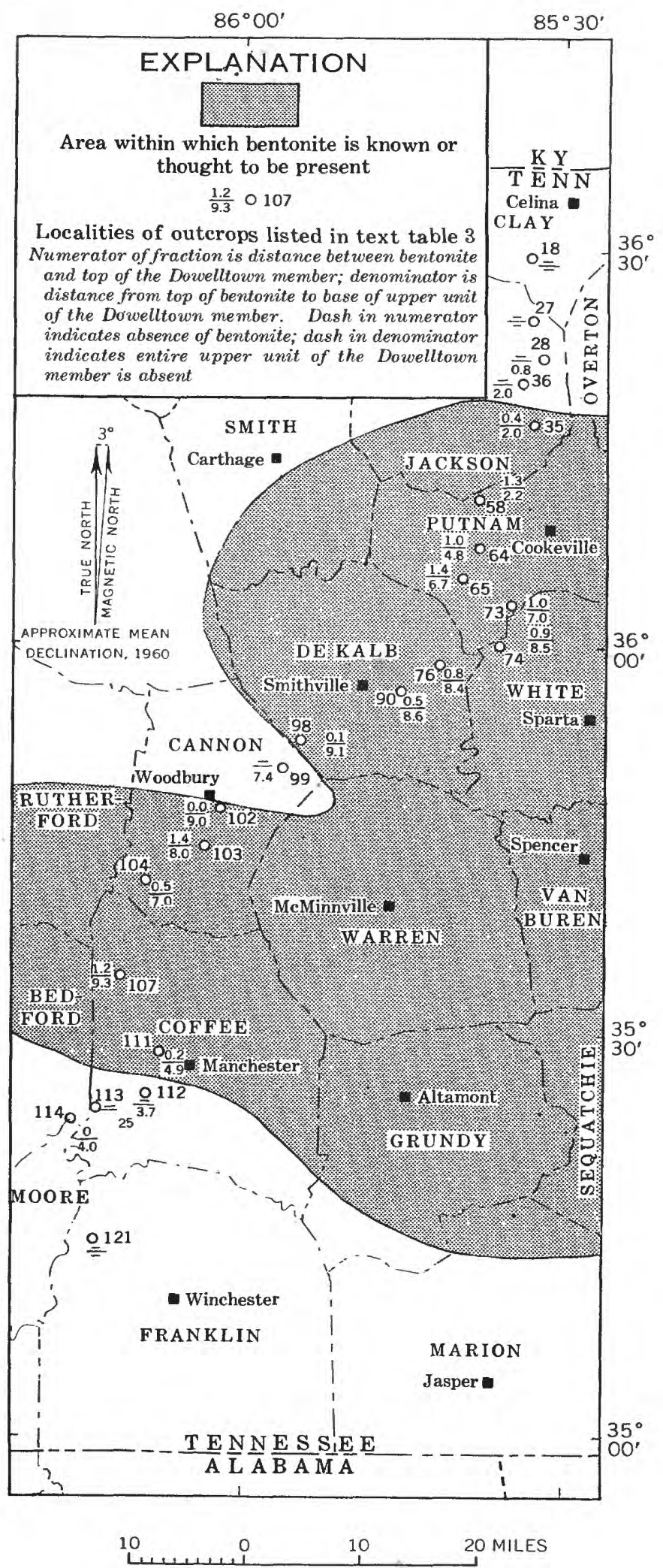

Froure 8.-Map of outcrops that show the thinning of the upper unit of the Dowelltown member.
TABLE 3.-Thickness data on the Dowelltown member, eastern edge of the Nashville Basin

[Localities listed from north to south. Measurements in feet. Dashes indicate unit

\begin{tabular}{|c|c|c|c|c|c|c|}
\hline \multirow[b]{2}{*}{$\begin{array}{c}\text { Locality } \\
\text { (pl. 1; table 13) }\end{array}$} & \multicolumn{4}{|c|}{ Dowelltown member } & \multirow{2}{*}{$\begin{array}{c}E \\
\text { Distance } \\
\text { between } \\
\text { bentonite } \\
\text { and top of } \\
\text { member }\end{array}$} & \multirow{2}{*}{$\begin{array}{c}F \\
\text { Distance } \\
\text { from top of } \\
\text { bentonite } \\
\text { to base of } \\
\text { upper unit }\end{array}$} \\
\hline & $\begin{array}{c}A \\
\text { Total }\end{array}$ & $\begin{array}{c}B \\
\text { Upper } \\
\text { unit }\end{array}$ & $\begin{array}{c}C \\
\begin{array}{c}\text { Lower } \\
\text { unit }\end{array}\end{array}$ & $\begin{array}{c}D \\
\text { Ratio of } \\
\text { upper to } \\
\text { lower } \\
\text { unit }\end{array}$ & & \\
\hline & & & 5.3 & & & \\
\hline 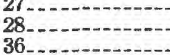 & $\begin{array}{l}4.0 \\
5.0\end{array}$ & & $\begin{array}{l}4.0 \\
4.2\end{array}$ & 0.19 & & $\ldots$ \\
\hline & $\begin{array}{l}6.1 \\
8.9\end{array}$ & $\begin{array}{l}2.0 \\
2.4\end{array}$ & $\begin{array}{l}4.1 \\
6.5\end{array}$ & $\begin{array}{l}.49 \\
.37\end{array}$ & 0.4 & \\
\hline 68 & $\begin{array}{r}9.6 \\
11.0\end{array}$ & $\begin{array}{l}3.5 \\
5.8\end{array}$ & & .57 & $\begin{array}{l}1.3 \\
1.0\end{array}$ & \\
\hline 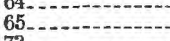 & 14.6 & 8.1 & $\begin{array}{l}6.2 \\
6.5\end{array}$ & 1.2 & 1.4 & 6 \\
\hline & $\begin{array}{l}13.6 \\
16.1\end{array}$ & $\begin{array}{l}8.0 \\
9.4\end{array}-10$ & $\begin{array}{l}5.6 \\
6.7\end{array}$ & $\begin{array}{l}1.4 \\
1.4\end{array}$ & $\begin{array}{c}1.0 \\
.9\end{array}$ & $\begin{array}{l}7 \\
8\end{array}$ \\
\hline & 15.4 & 8.2 & 6.2 & 1.5 & .8 & 8 \\
\hline $90-198$ & $\begin{array}{l}15.9 \\
15.0\end{array}$ & $\begin{array}{l}9.1 \\
9.2\end{array}$ & $\begin{array}{l}6.8 \\
5.9\end{array}$ & $\begin{array}{l}1.3 \\
1.5\end{array}$ & .5 & $\begin{array}{l}8.6 \\
9.1\end{array}$ \\
\hline 99-......... & 12.2 & $\begin{array}{l}7.4 \\
8.0\end{array}$ & $\begin{array}{l}4.8 \\
9.5\end{array}$ & $\begin{array}{l}1.5 \\
.95\end{array}$ & 0 & \\
\hline (n...- & 16.2 & 9.4 & 6.8 & 1.4 & 1.4 & \\
\hline -........ & 16.4 & $\begin{array}{r}7.5 \\
10.5\end{array}$ & 8.9 & .84 & .5 & \\
\hline 107 & $\begin{array}{l}18.4 \\
14.0\end{array}$ & $\begin{array}{r}10.5 \\
5.1\end{array}$ & 8.9 & $\begin{array}{l}1.5 \\
.57\end{array}$ & 1.2 & 4.8 \\
\hline $112 \ldots \ldots \ldots$ & 10.0 & 3.7 & 6. & .59 & & \\
\hline & & & 6. & .38 & & \\
\hline & & 4.0 & 1.1 & 3.6 & & \\
\hline & & & & & & \\
\hline
\end{tabular}

unobserved disastems in the lower part of the gray-bed unit cut out gradually increasing amounts of the unit northward. Another possible explanation is that less deposition was taking place at that time in the northern area, but this one too seems unlikely, for in general the beds tend to be somewhat coarser in that direction.

\section{GASSAWAT MEMBER IITHOLOGIC CHARAOTERISTIOS}

The upper member of the Chattanooga shale in its typical outcrops and throughout most of the area of this study is a massive black shale having no conspicuous subdivisions, though in many places a few inconspicuous beds of gray claystone are present near the middle of the member. In general, the black shales of the Gassaway member are somewhat more massive than are the shale beds of the Dowelltown member (pl. $10 \mathrm{~A}$ ), and along the northern edge of the Basin they are somewhat darker. When broken the black shale emits a distinctly petroliferous odor. In the freshest exposures the shale commonly breaks with a conchoidal fracture, but where weathered it is finely fissile and breaks into thin sheets (pl. 10B).

Even the most massive shale in the formation contains discontinuous thin laminae of siltstone, most of which are so inconspicuous that they are seen only on freshly broken or polished faces (pl. 9D). Apparently the organic matter binds the fresh rock together, but weathering opens cracks parallel to the extremely thin laminae in the rock. 


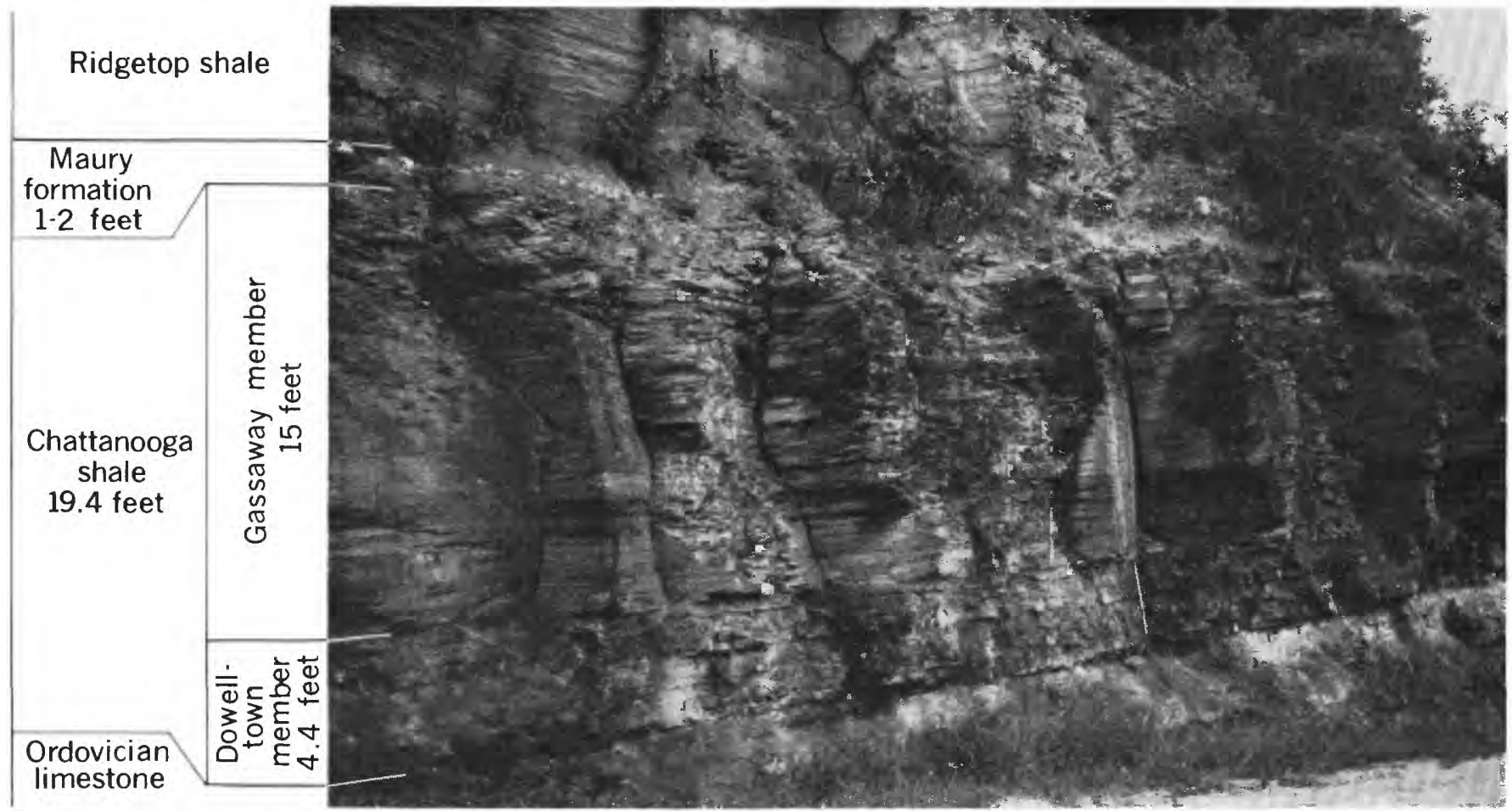

A. MASSIVE BLACK SHALE OF THE GASSAWAY MEMBER OF THE CHATTANOOGA SHALE SHOWN IN CONTRAST WITH THE FRIABLE SHALE OF THE DOWELLTOWN MEMBER

1 A lenticular sandstone bed as much as 0.25 foot thick, at the base of the Gassaway, is correlated with the Bransford sandstone bed. The white rule across most of the Dowelltown is 3.5 feet long and stands on the 0.8-foot basal sandstone of the Chattanooga. The Maury formation, which has phosphate nodules in the middle, grades into the overlying Ridgetop shale. Locality 195.1950.

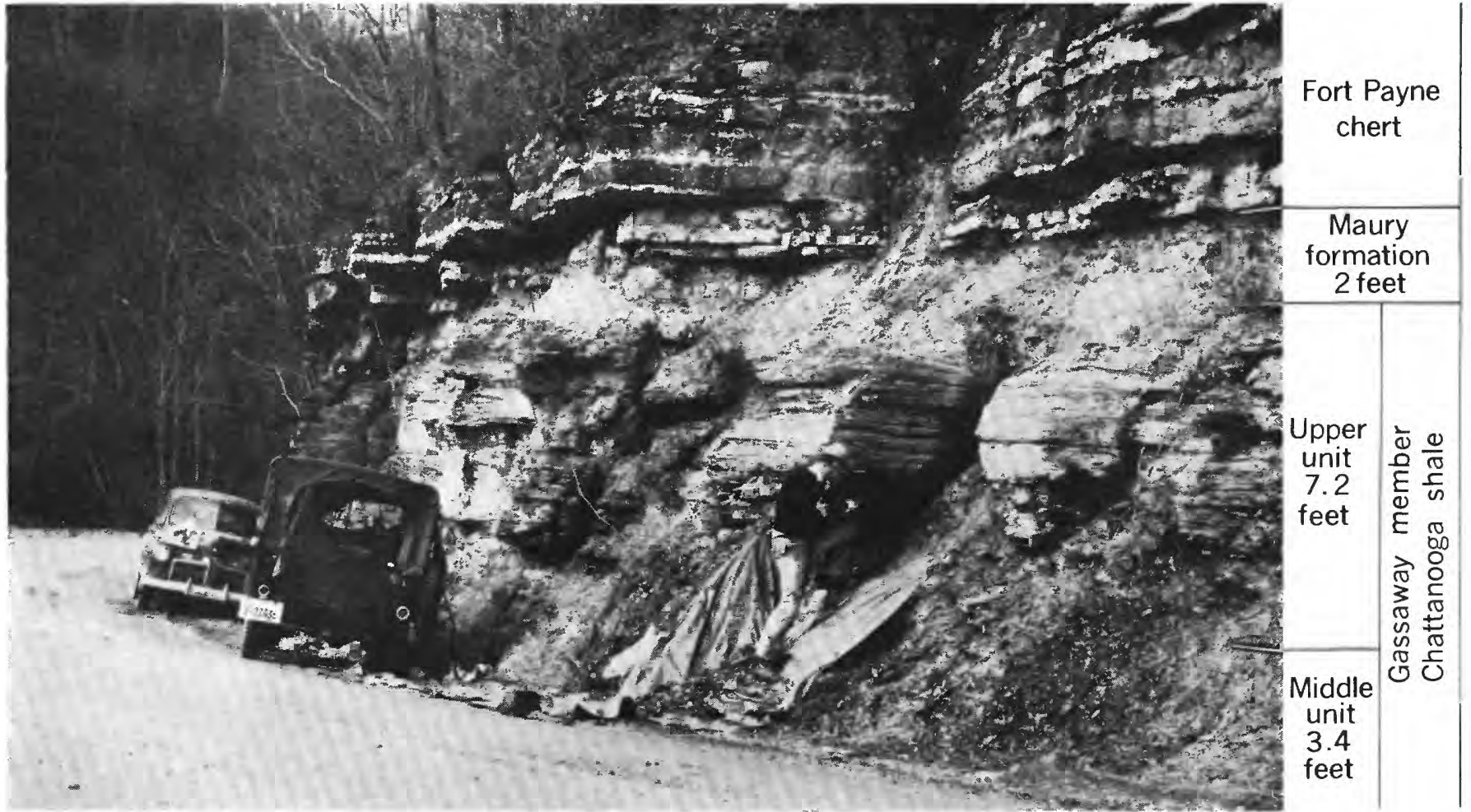

B. TYPICAL OUTCROP OF WEATHERED CHATTANOOGA SHALE, IN ROAD CUT

Weathering has brought out a latent fissility and caused the rock to break into small shaly pieces. The man's left foot is at the top of the middle unit of the Gassaway member. The position of the Maury is marked by a reentrant just below the chert beds of the Fort Payne. Locality 78. Photograph by Andrew Brown, 1948 . 


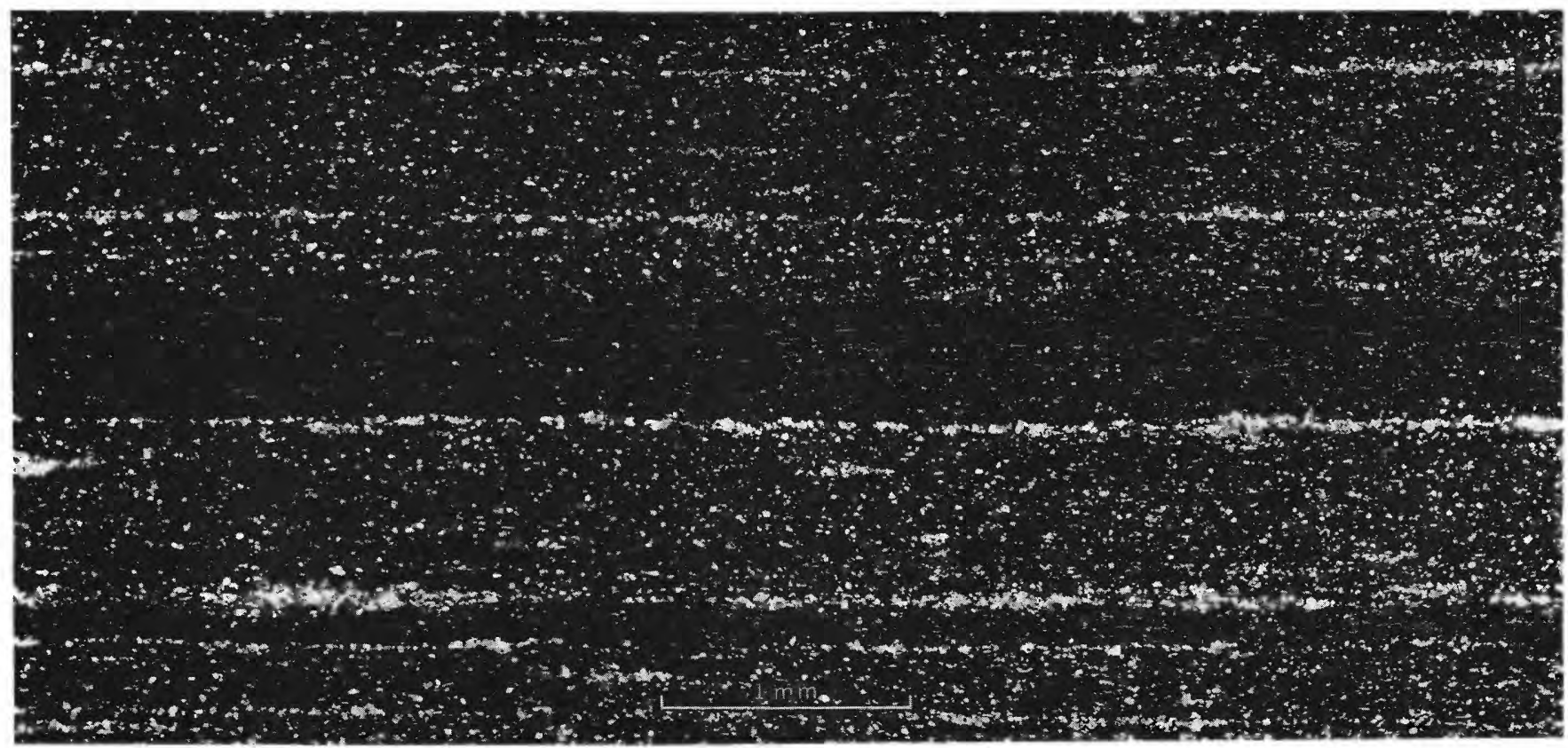

A. PHOTOMICROGRAPH OF BLACK SHALE OF THE UPPER UNIT OF THE GASSAWAY MEMBER SHOWING REGULARITY OF THE LAMINATION

Note the paper-thin, more or less regular laminae of quartz siltstone interbedded with thin beds of more variable composition. Most of the equidimensional grains are quartz; most of the elongated light particles in the central dark band are resinous matter. Abundant organic matter caused a normal thin section like this one to be largely opaque. From a diamond-drill core taken from locality 93 . Photograph by J. M. Schopf, $\times 38$.

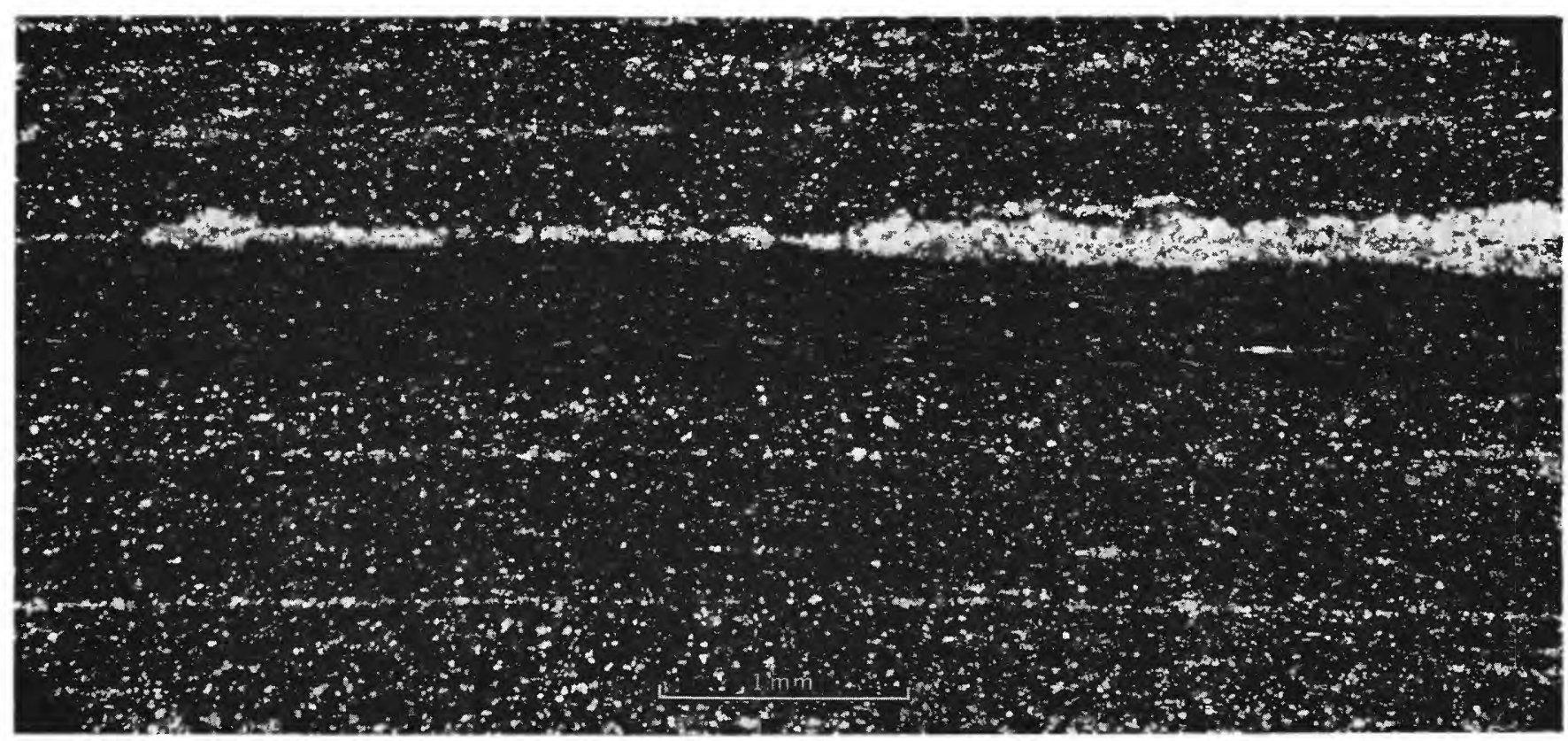

B. PHOTOMICROGRAPH OF BLACK SHALE OF THE UPPER UNIT OF THE GASSAWAY MEMBER SHOWING IRREGULARITY OF THE LAMINATION Note the bed of quartz siltstone that pinches and swells markedly within the length of a l-inch-thick section. Same specimen as $A$ above. Photograph by J. M. Schopf. $\times 38$. 


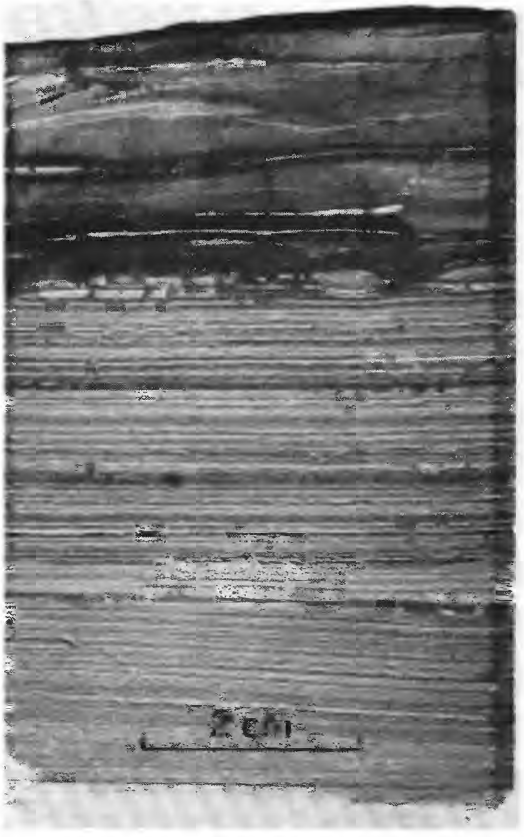

A. "VARVED" BED AT BASE OF MIDDLE UNIT OF THE GASSAWAY MEMBER OF THE CHAT. TANOOGA SHALE

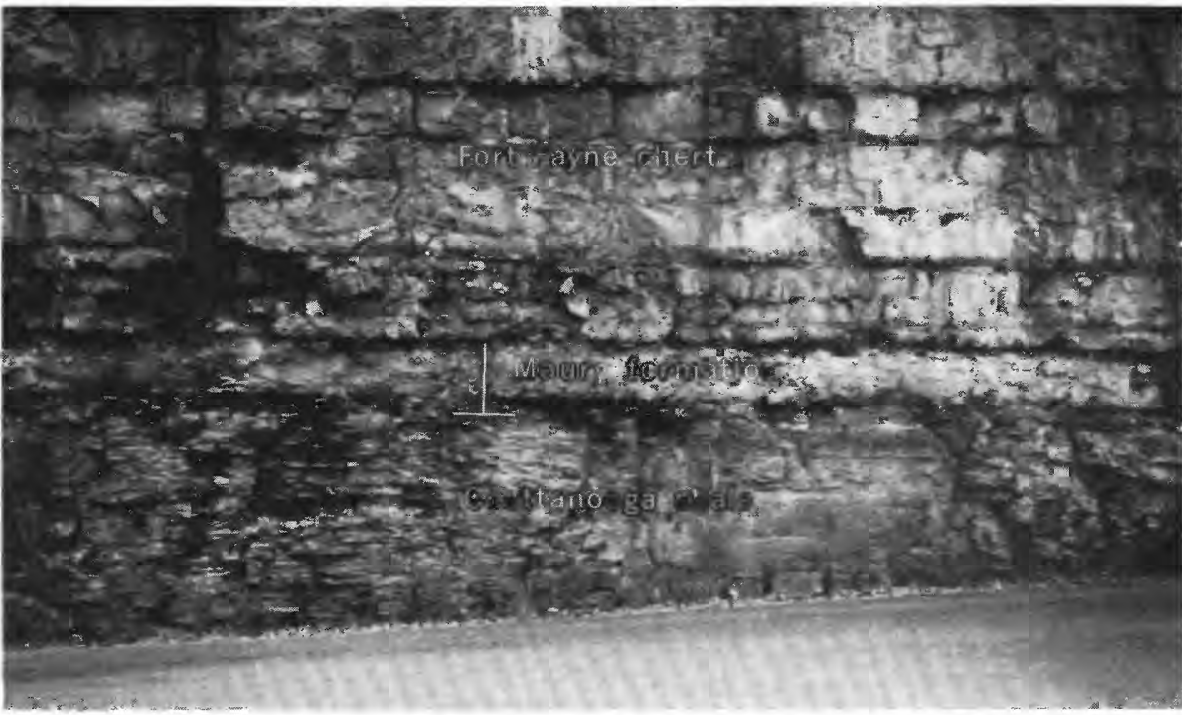

B. MAURY FORMATION BETWEEN THE FORT PAYNE GHERT AND THE CHATTANOOGA SHALE

The inverted T-rule rests on top of the Chattanooga shale, and its top almost reaches the top of the Maury, here 2.6 feet thick. Phosphate nodule layer at base of Maury is here about 6 inches thick. Massiveness of the For Payne chart is well shown. Locality 82. 1950.

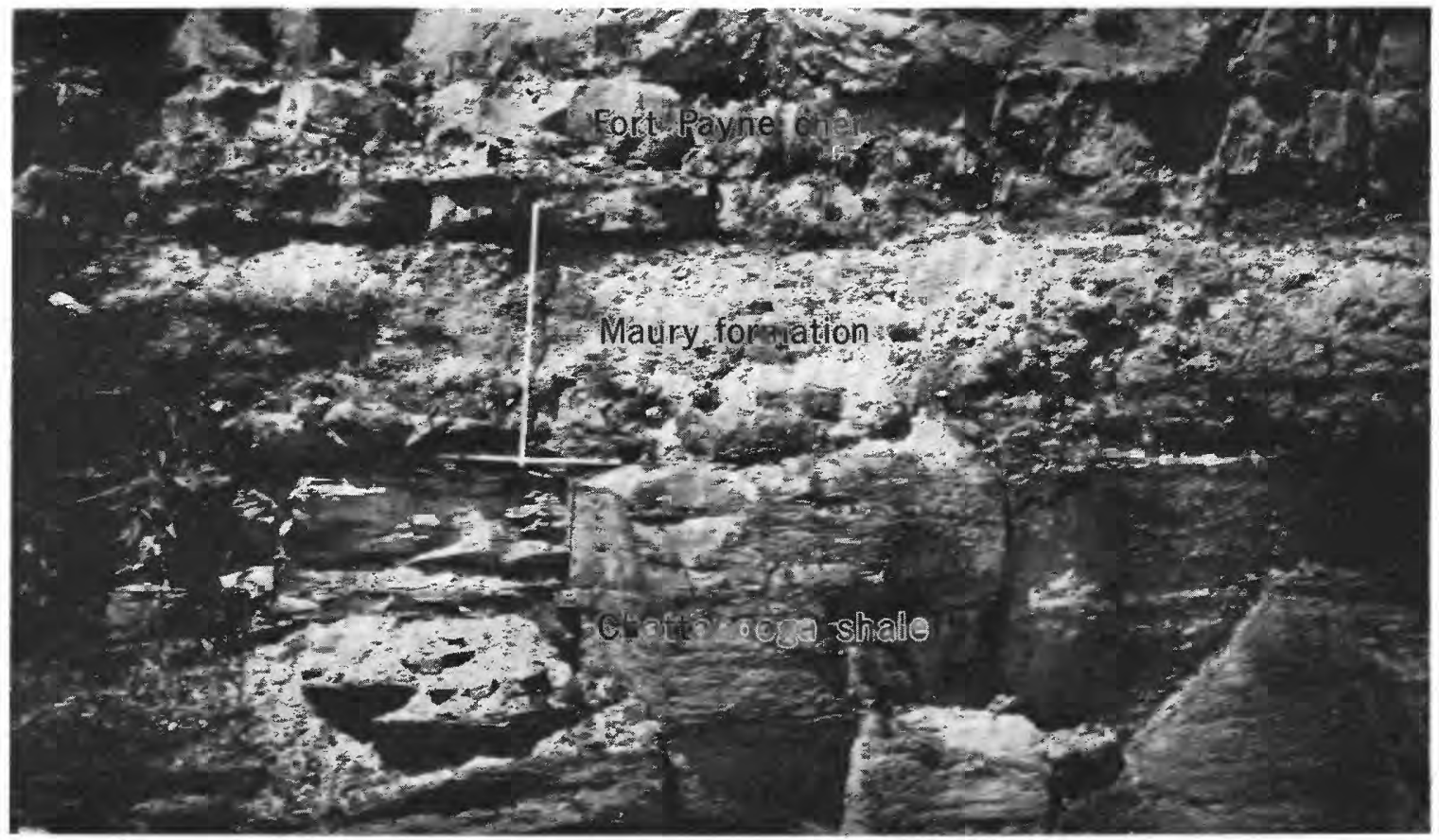

C. MAURY FORMATION

Base of inverted T-rule rests on massive Gassaway member of the Chattanooga shale. Maury is here 2.7 feet thick. Phosphate nodules occupy lower 1 foot. Rule is 3 feet high. Locality 76 . 1950. 


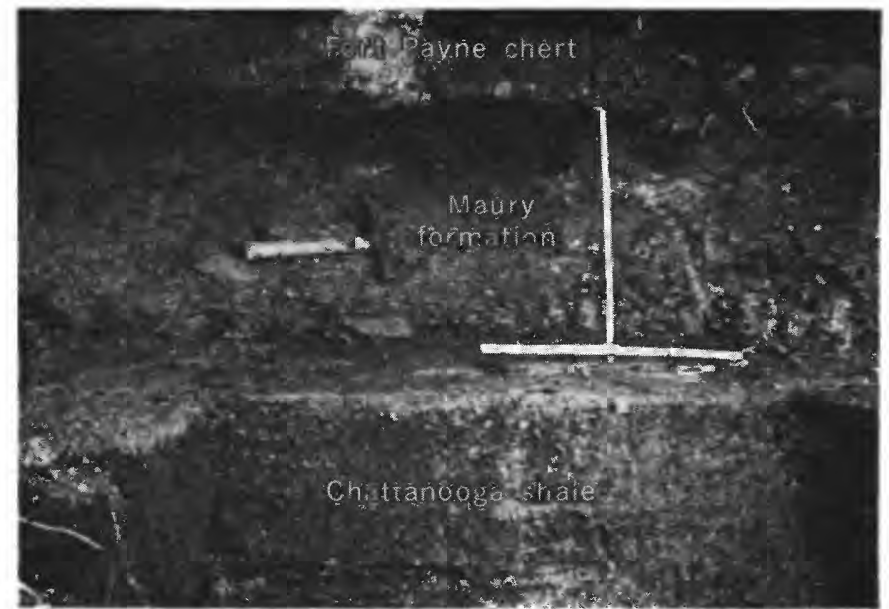

A. STANDARD SECTION OF THE MAURY FORMATION

The inverted T-rule, 1.5 feet high, rests on the Chattanooga shale and touches the Fort Payne chert. The hammer head spans the interval of abundant large phosphate nodules. Locality 185.1952.

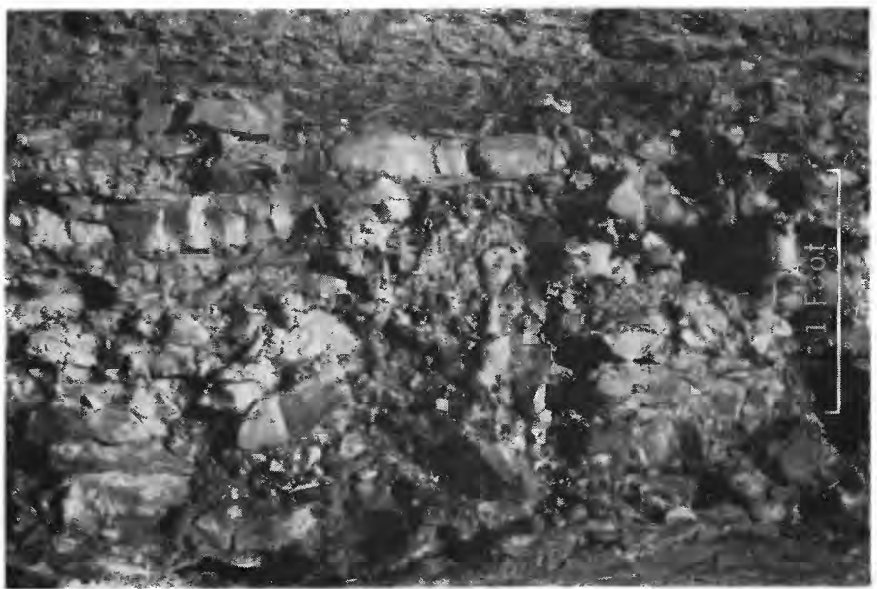

$B$. PHOSPHATE NODULE BED AT BASE OF THE MAURY FORMATION

The bed here is nearly 2 feet thick, one of the thickest exposures known. Note the variety of shapes, sizes, and orientations of the nodules. Locality 68. Photograph by T. M. Kehn, 1953.

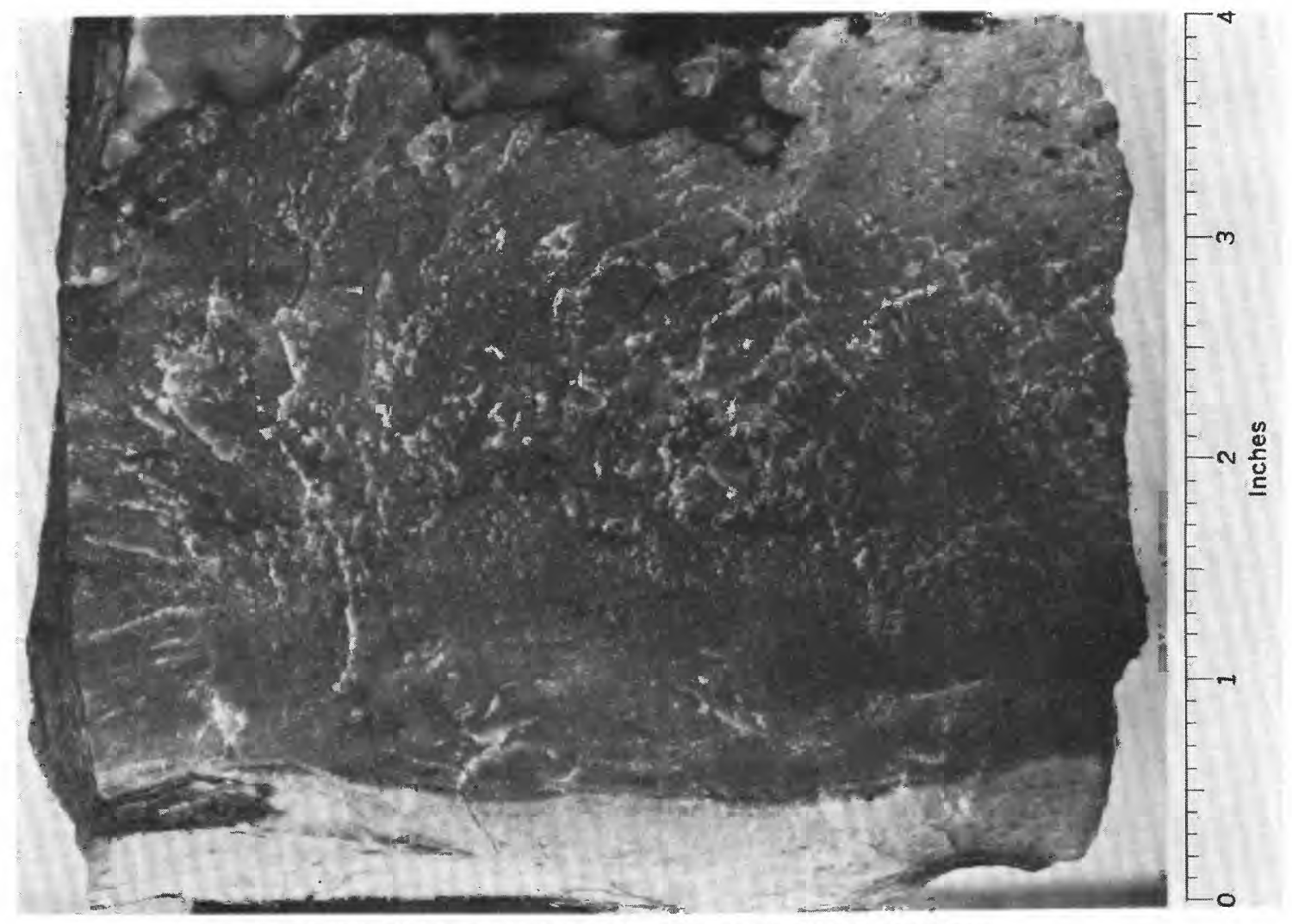

C. CONTACT BETWEEN FORT PAYNE CHERT AND MAURY FORMATION

The lower half inch is Maury, the upper half inch is massive chert of the Fort Payne. The large central part is cherty limestone of the Fort Payne that has scattered blue-green chips like the dark mass within the Maury at left. Specimen from Locality 68. 
Petrographic examination shows the shale to be composed of finely laminated quartz, clay, organic matter, pyrite, and other constituents, most of the grains being in the size range of silt and clay. The sorting and lamination are pronounced, and many of the laminae are only paper thin and are composed almost wholly of quartz (pl. 11A, $B$ ). The discontinuity and irregularity of the siltstone laminae that are visible at most outcrops and in thin sections (figs. 31 and 33) indicate the small irregularities that characterized the floor of the Chattanooga sea and the deposition thereon.

Wherever beds of the Dowelltown member are missing and the Gassaway member is at the base of the formation, the Gassaway commonly has a sandstone at the base a fraction of an inch to a foot thick. The sandstone normally contains the conodonts Palmatolepis glabra, $P$. perlobata, Polylophodonta confluens, and others that are restricted to the Gassaway (Hass, 1956).

Along the northwestern edge of the basin, where both the Dowelltown and Gassaway members are present, a thin bed of sandstone is present at the base of the Gassaway member at almost every good outcrop. Mather (1920, p. 19), Bassler (1932, p. 140), and Campbell $(1946$, p. 884$)$ have previously called attention to this sandstone. Campbell designated it the Bransford sandstone member of his Gassaway formation, and we are referring to it as the Bransford sandstone bed. The sandstone contains abundant conodonts, a few small bone fragments, and parts of Cyclora-like gastropods that have been derived from the Ordovician limestones. One of the best and thickest exposures of this sandstone is in the railroad cut at Bakers Station in northern Davidson County (loc. 204) where it is about 4 inches thick. Where Campbell chose the type locality of his Bransford sandstone member, in eastern Sumner County (loc. 206), it is generally about 0.1 foot thick. Table 4 summarizes some of the observed thicknesses of this sandstone bed and shows the thicknesses of the overlying and underlying shale.

TABLE 4.-Thicknesses of units at selected outcrops where the Bransford sandstone bed is present

\begin{tabular}{c|r|c|c}
\hline \multirow{2}{*}{ Locality (pl. 1; table 13) } & \multicolumn{3}{|c}{ Thickness (in feet) } \\
\cline { 2 - 4 } & $\begin{array}{c}\text { Gassaway } \\
\text { member }\end{array}$ & $\begin{array}{c}\text { Bransford } \\
\text { sandstone } \\
\text { bed }\end{array}$ & $\begin{array}{c}\text { Dowelltown } \\
\text { member }\end{array}$ \\
\hline 22 & 13 & $0.01(?)$ & 4.4 \\
192 & 12.6 & .2 & 8.6 \\
195 & 15 & $0-0.25$ & 4.3 \\
164.6 & $0-.4$ & 16.9 \\
206 & 16.1 & $0-0.2$ & .1 \\
\hline
\end{tabular}

Farther eastward the examined outcrops do not show the Bransford sandstone bed consistently, but at a few places as far east as Jackson County 10 to 15 feet of massive black shale is underlain by thin beds or films of conodont-rich sandstone that may be the basal bed of the Gassaway member. The sandstone bed was not observed in outcrops along the eastern edge of the Nashville Basin, but several diamond-drill cores taken during the summer of 1953 in the vicinity of Smithville and elsewhere along the Eastern Highland Rim from Jackson County to Coffee County show an obscure layer of siltstone, at most a few millimeters thick, at or near the base of the Gassaway member. This is probably an equivalent of the Bransford sandstone bed along the northern edge of the basin.

In the northern part of Tennessee and generally in Kentucky, the topmost beds of the Gassaway member contain phosphate nodules that are commonly scattered throughout the upper few feet but locally are concentrated in one or more courses. This nodule-bearing shale is commonly overlain by a profusion of more tightly packed nodules at the base of the Maury formation (pl. 16B).

At a few places, particularly in northeastern Mississippi and in the adjacent part of Tennessee, the entire Gassaway member consists of sandy shale and sandstone. These beds are commonly dark gray to black, contain the usual large amount of comminuted plant matter, and are somewhat glauconitic. This type of material is especially characteristic near the Whetstone Branch (loc. 235) outcrops in northeastern Mississippi that were described by Morse $(1930$, p. 50-53). Mellen (1947, p. 1811) pointed out that in this area the shale is progressively sandier to the west, and apparently this area is near the ancient shoreline of the Chattanooga sea.

\section{EXTENT AND THICKNESS}

The Gassaway member has much the widest distribution of any part of the formation; it was identified either by lithologic character or by conodonts at every outcrop of the black shale that was studied (pl. 7). Along most of the northern and eastern edges of the Nashville Basin it is typically 15 to 20 feet thick (pl. 12). In the southern and western parts of the Basin and the southern half of the western valley of the Tennessee River, the Gassaway, is much thinner and generally constitutes the entire thickness of the Chattanooga shale, including those places where the formation is only a few feet or a few inches thick. To the northeast, along the Cumberland Valley of Kentucky, the Gassaway thickens to about 40 feet. In northern Alabama and Georgia its thickness ranges from 0 to at least 40 feet. The phosphate-bearing black shale at the top of the Gassaway is as much as 8 feet thick in south- 
ern Kentucky but decreases in thickness southward until it disappears in DeKalb and White Counties, Tenn. In most of Tennessee the thickness of the Gassaway member is probably roughly proportional to the length of time the sea covered any given area.

As with the Dowelltown member (p. 29) the Gassaway member was found, in a 15-mile series of drill cores and outcrops near Smithville, to thin westward toward the Nashville Basin. This thinning, shown in figure 10, amounts to about 5 feet. Careful measurements also show (figs. 9, 10) that some lithologic units tend to be thicker in the synclines and thinner in the anticlines. This relation suggests that the flexures were mildly active during the time of Chattanooga deposition, so that more muds accumulated in sagging areas - a small-scale illustration of the conditions we think existed in the Flynn Creek cryptoexplosive area: that is, where the sea bottom was sagging, the shifting muds kept the sea bottom level.

\section{IOWER AND UPPER CONTACTS}

The contact between the Dowelltown and Gassaway members was discussed in the section dealing with the Dowelltown member (p. 29). Along the eastern edge of the basin the exact base of the Gassaway is identified in some places with difficulty because of the presence of two or three thin beds of gray claystone in what is probably the lower half foot of the member, but commonly the interval of uncertainty is not over 6 inches thick.

Locally at the top of the Gassaway member (top of the Chattanooga shale) there may be another obscure unconformity, though satisfactory evidence for it is hard to find. At most places the contact with the base of the Maury formation is line sharp, but other physical evidence of an unconformity is almost wholly lacking. A quarry outcrop in Limestone County, Ala. (loc. 142), shows about 1 foot of Chattanooga shale, but elsewhere along the remaining few hundred feet of the exposure the Maury formation rests directly on shale of Silurian age. Near Waynesboro, in Wayne County, Tenn. (loc. 242), a poorly exposed creek bank outcrop shows the Maury resting with apparent unconformity on gently folded Chattanooga shale. At the excavation for the New Johnsonville steam plant site in Humphreys County, Tenn. (loc. 253), where the rocks are badly disturbed, about 1 inch of conglomerate is present locally at the apparent base of the Maury. These three outcrops are suggestive of local erosion before Maury time, but the evidence is not conclusive.

Cores that were obtained during drilling in 1953 along the Eastern Highland Rim, especially near Smithville, DeKalb County, reveal what might be considered additional evidence for an unconformity at the top of the Chattanooga shale. Correlations of the cores taken at east-west intervals of about 1 mile for distances of 12 to 14 miles (figs 9,10 ) show irregularities at the top of the Gassaway member that may indicate an erosional interval before the overlying Maury formation was deposited. This evidence consists of (a) differences in thicknesses of the upper unit of the Gassaway that can best be explained by assuming an erosion interval at the close of the Chattanooga deposition, and (b) the presence at one place, drill hole 29 (fig. 10), of an apparent outlying mass of the phosphate-bearing shale beds that constitute the topmost part of the formation farther north but that are generally absent in the region of the drill cores.

Hass $(1956$, p. 23), on the basis of his studies of the conodonts, found evidence of a time break at the top of the Chattanooga shale in much of the area of our study. This evidence is the absence in large areas of the distinctive conodont fauna that is associated with the uppermost part of the Chattanooga shale that characteristically contains scattered phosphate nodules. Where the phosphate-bearing black shale beds at the top of the formation are thin or missing, a time of erosion or of nondeposition may be represented, though little physical evidence was found to substantiate this interpretation.

\section{BASIS FOR SUBDIVISION}

Three persistent lithologic subdivisions of the Gassaway member were traced for about 80 miles along the western edge of the Nashville Basin. This three-fold division is based entirely on the presence of a thin middle unit, 2 to 3 feet thick, in which a few inconspicuous gray claystone beds are present within the otherwise massive black shale (fig. 5).

At places where the middle unit of the Gassaway member is absent, no satisfactory basis was found for subdividing the member. Where the Gassaway is more than 7 or 8 feet thick and the middle unit is not recognizable, it is probable that the black shale represents the interval of the middle unit as well as parts of the lower and upper units.

\section{IOWER JNIT}

The lower unit of the Gassaway member in most places consists almost wholly of massive black shale having paper-thin partings of very fine sandstone or siltstone. Pyrite is present as films, thin lenses, and scattered nodules. This unit of the Gassaway member is commonly about 5 to 8 feet thick on the eastern edge of the basin where it can be differentiated from the black shale of the upper unit of the Gassaway by the presence of the intervening unit of claystone beds. 

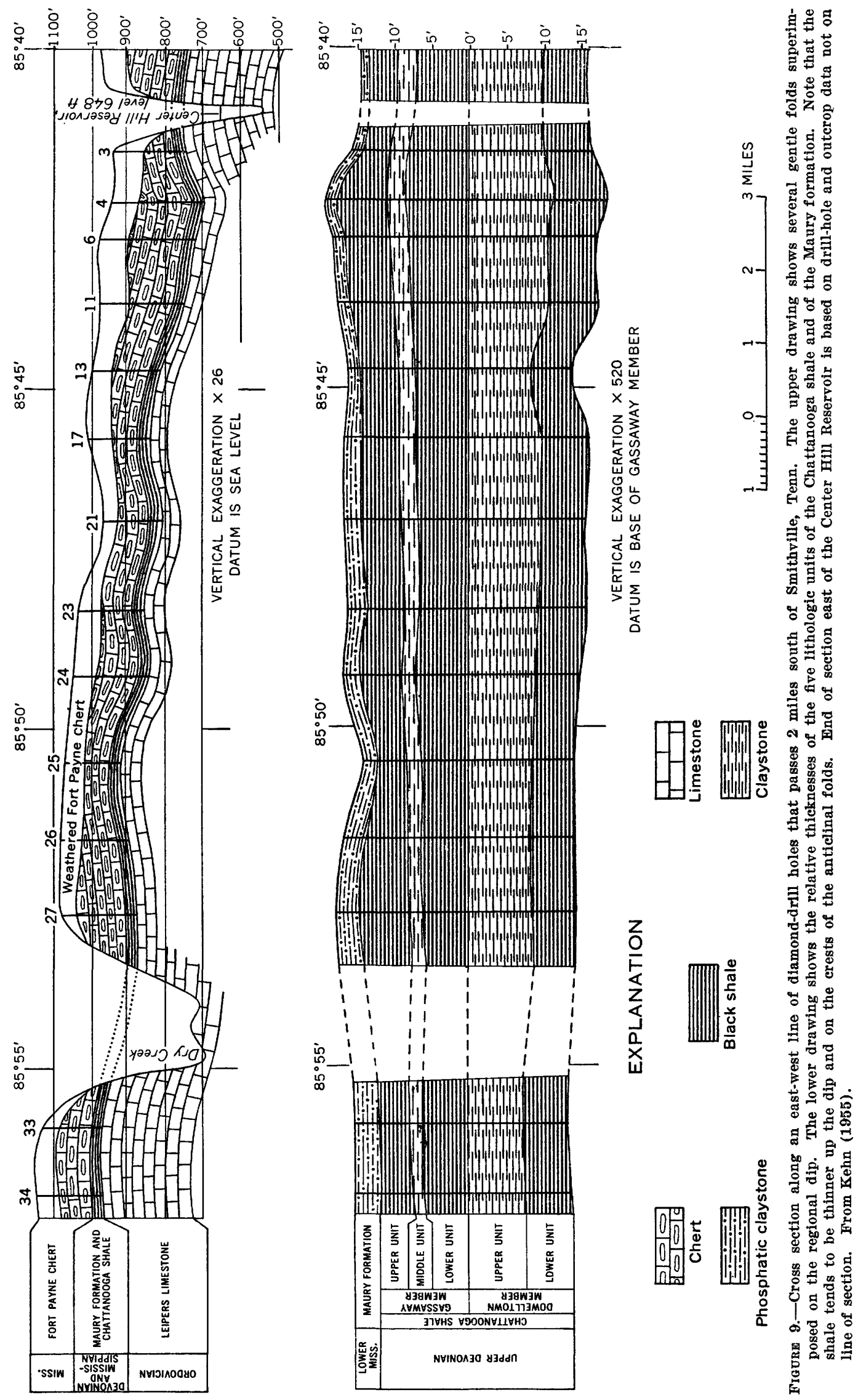

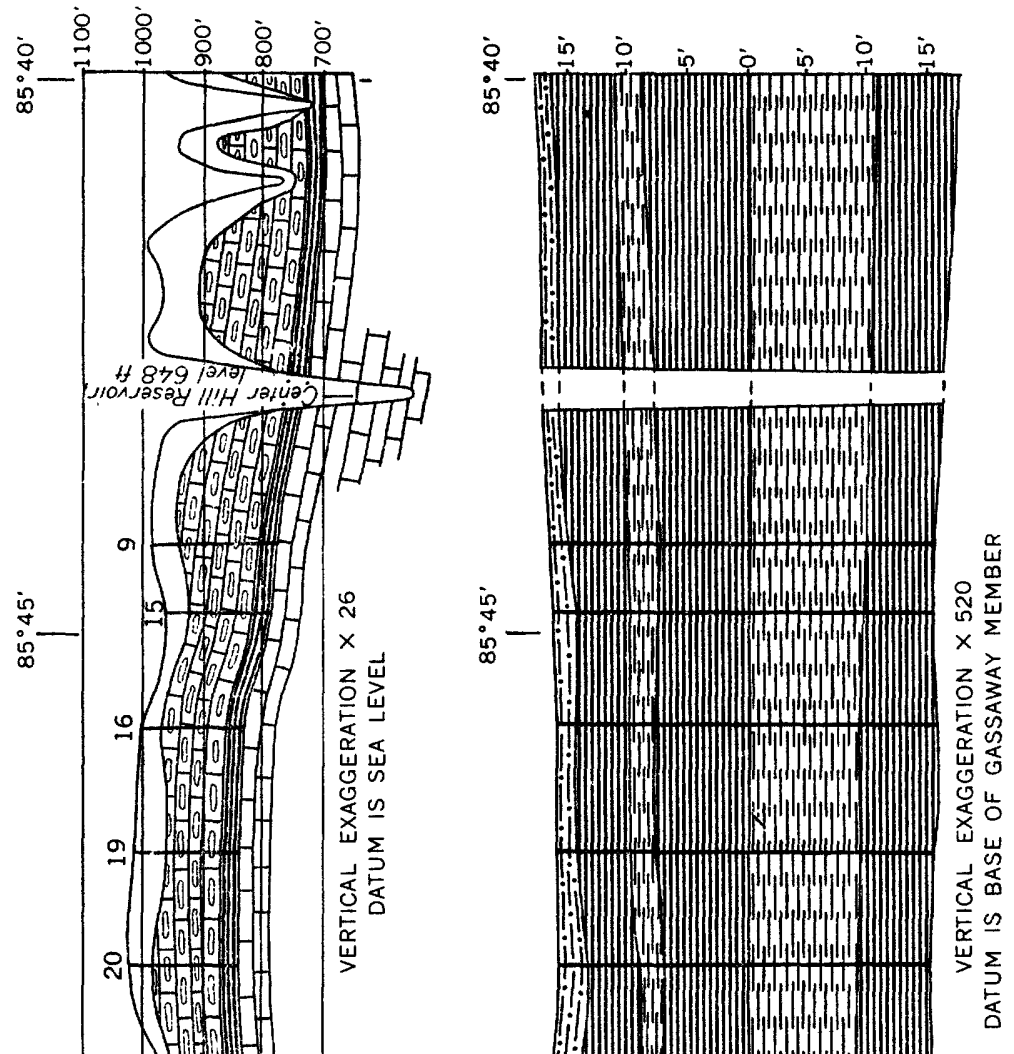

㽞
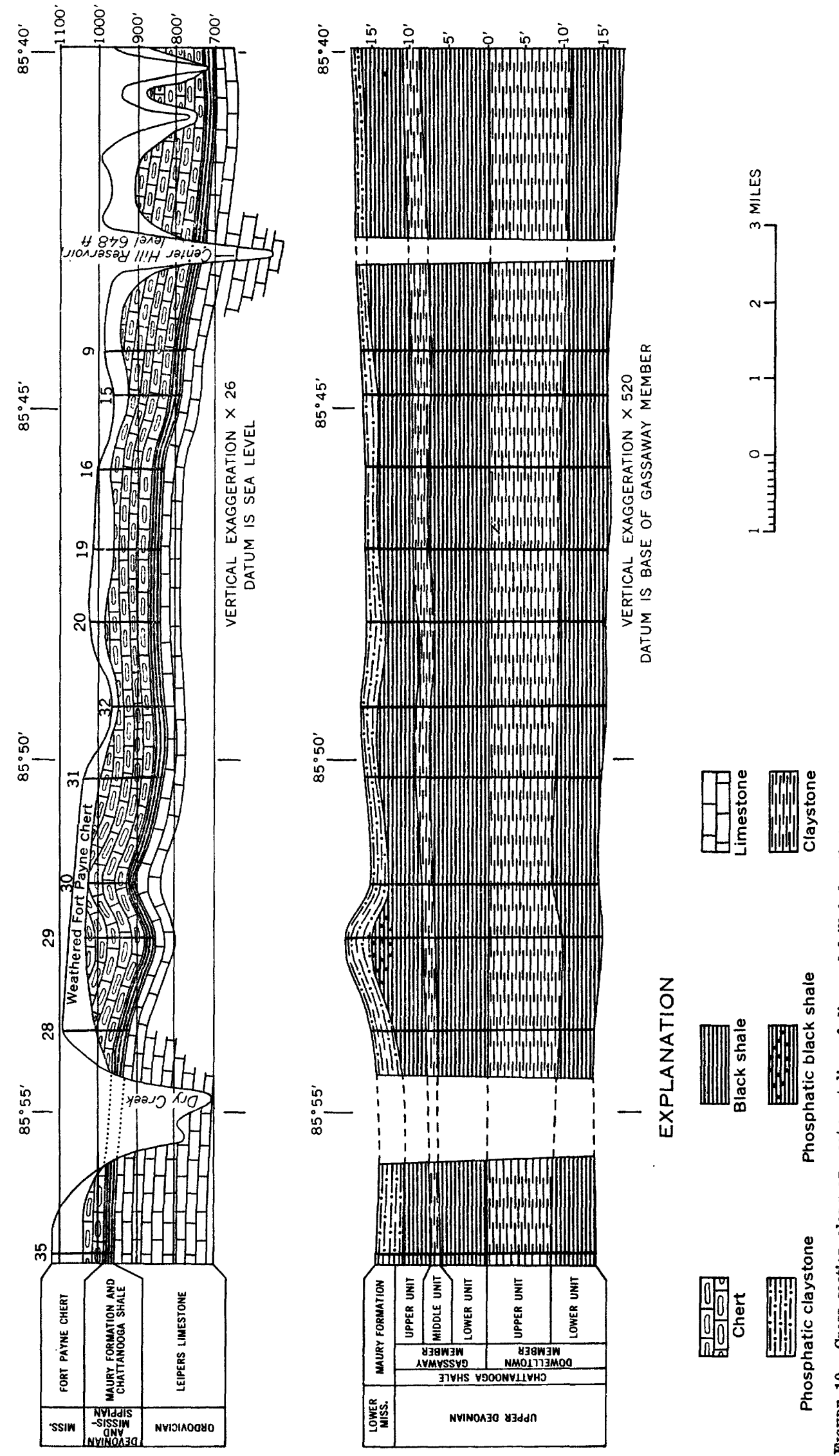

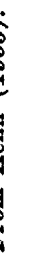


SOUTH

NQRTH

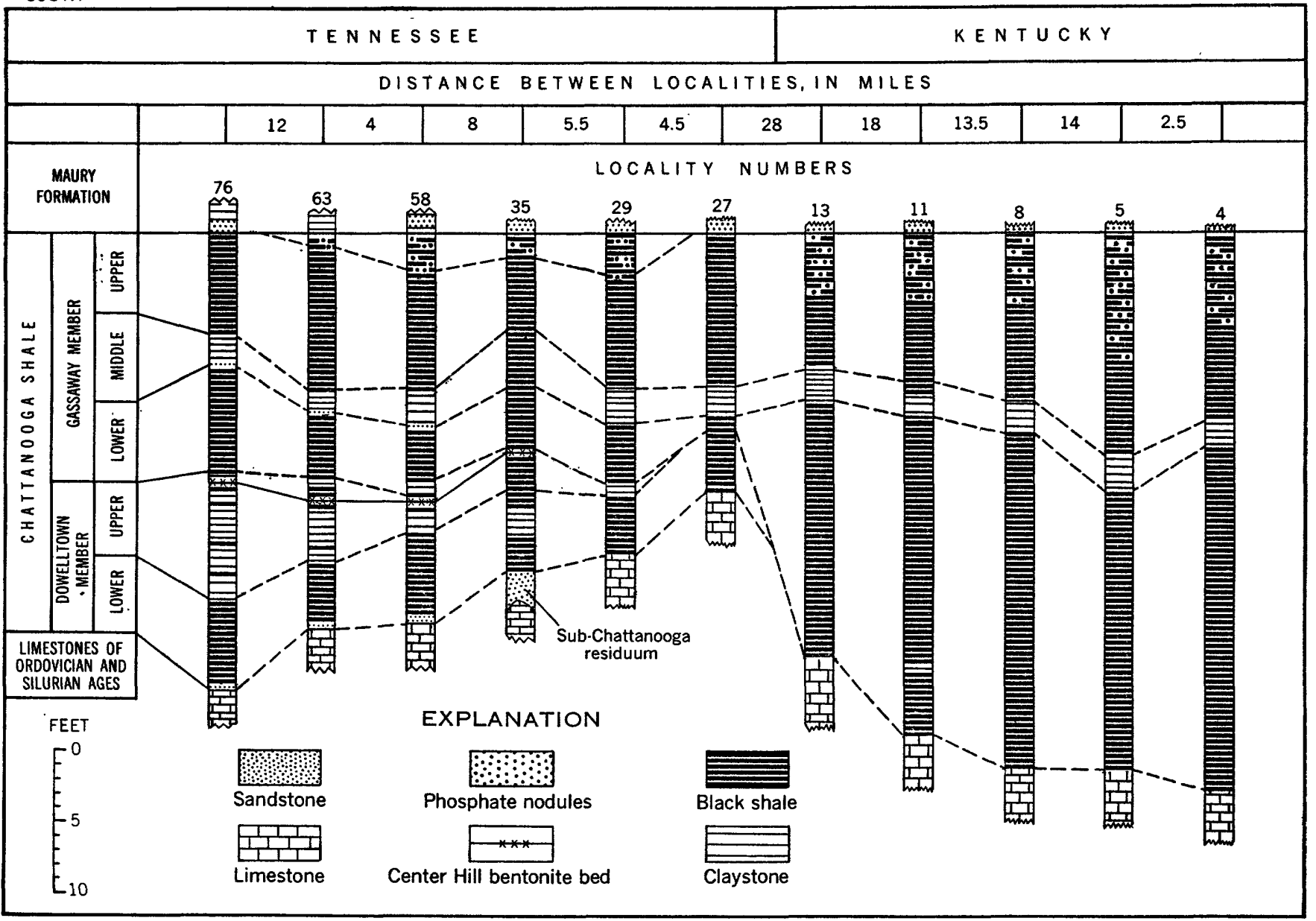

Figure 11.-Correlation of units of the Chattanooga shale in northern Tennessee and southern Kentucky. Locality 35 is the northernmost one where the 5 indicated subdivisions of the Chattanooga and the Center Hill bentonite bed have been positively identified.

Along the northeastern edge of the basin, where the underlying gray claystone of the Dowelltown member is either thin or absent and the overlying middle unit of the Gassaway is also thin, this lower unit of the Gassaway is only about 2 to 4 feet thick. These relationships in the northeast corner of the Basin are shown in figure 11. Farther north, in Kentucky, the lower unit thickens to about 20 feet.

\section{MIDDLE UNIT}

Along the eastern edge of the Nashville Basin the middle unit of the Gassaway member, about 2 to 3 feet thick, contains a few gray claystone beds about 1 to 2 inches thick, which set this unit apart from the lower and upper black shale units of the Gassaway (fig. 5). This obscure but persistent unit is easily overlooked in a casual examination of an outcrop, but its distinctive characteristics aid greatly in correlating the shale from place to place. A bed of fine to very fine sandstone at the base of this unit is commonly 1 to 4 inches thick, but its thickness is so variable that in some exposures it pinches out laterally in a few feet from a 2 -inch bed to a mere film. The top of the middle unit is arbitrarily placed at the top of the highest bed of gray claystone.

The sandstone bed at the base of the middle unit of the Gassaway member shows such a marked alternation of thin carbonaceous shale and noncarbonaceous layers of very fine sandstone and siltstone as to give the appearance of a varved bed (pl. 13A). It is finely cross laminated and ripplemarked. At most outcrops the color of the noncarbonaceous layers is light brown, and the bed as a whole has a rusty brown appearance that contrasts with the blacks and grays of the other beds of the Chattanooga shale. In unweathered samples the sandstone and siltstone are light gray. The base is invariably sharp and rests on a bed of black shale. The bed grades upward into the overlying black shale by a gradual increase in thickness of the black layers, a corresponding thinning of the brown layers, and a decrease in grain size from very fine sandstone to siltstone. Though informally referred to as the "varved" 
bed, there is no evidence that seasonal fluctuations are involved. The bed is present at nearly every outcrop for 50 miles along the eastern edge of the Nashville Basin from Putnam County to Coffee County. In the easternmost outcrops in Putnam and DeKalb Counties the bed is thinner and difficult to find, but in the more western outcrops of the Eastern Highland Rim it is thicker and slightly coarser grained. At some outcrops, especially near the northeast corner of the basin, one or more somewhat similar beds were seen at higher positions, but most of those beds grade both upward and downward into the black shale.

Along most of the eastern edge of the basin the middle unit of the Gassaway member contains about four or five beds of gray claystone, but farther north, in Jackson County, only three claystone beds are consistently present. Widely scattered observations indicate that the unit is also present in Clay County at the north edge of Tennessee and in Monroe and Cumberland Counties in southern Kentucky. Farther northeast in the area of the Wolf Creek Reservoir, a similar unit about 2 feet thick also has three beds of the gray claystone and is believed to be correlative with the one in Tennessee (fig. 11) ; if it is, the unit is almost continuous for a north-south distance of at least 140 miles.

Along much of the northern edge of the Nashville Basin the middle unit cannot be identified, but a persistent thin pyritic sandstone or siltstone bed is at the approximate position of the "varved" bed. The bed is about 2 to 3 inches thick and is 2 to 4 feet above the base of the Gassaway member. It is easily recognized on outcrops because the pyrite decomposes rapidly, leaving the bed slightly recessed and in some places covered with secondary sulfate minerals. The equivalence of this bed with some part of the middle unit of the Gassaway is suspected but not established.

The middle unit of the Gassaway member was not recognized along the southern, or western, edges of the basin, nor in the Sequatchie Valley to the southeast. Its absence in the southern part of the basin, where the Dowelltown member is also absent and where the Gassaway member is relatively thin, seems to indicate that this area was not submerged by the Chattanooga sea until a somewhat later time. The absence of this unit in the other areas probably signifies that the special conditions requisite for the formation of gray beds did not extend that far.

\section{UPPER UNIT}

The upper unit of the Gassaway member consists almost entirely of massive black shale and is similar to the black shale of the lower unit of the Gassaway except that it is somewhat more massive and tough.
Most fresh exposures commonly show conspicuous smooth joint facies that extend from top to bottom of the unit (pls. $6 \mathrm{~A}, 10 \mathrm{~A}$ ) and locally continue through the rest of the Gassaway member. This upper unit is probably present wherever the black shale is exposed and in some areas, especially southern Tennessee, is the only unit of the Chattanooga present. Apparently the Chattanooga sea had its greatest extent in this part of the United States in late Gassaway time.

Along the eastern edge of the basin the upper unit of the Gassaway member is commonly 6 to 7 feet thick, but along the southern edge it is locally thinner or absent, as is the entire formation.

North from DeKalb County, Tenn., the upper unit of the Gassaway member becomes appreciably thicker, in places as much as 13 feet. This greater thickness results largely from the presence of a northwardthickening wedge of phosphate-bearing black shale beds at the top. In northern Tennessee small scattered phosphate nodules are common in the upper 1 to 3 feet of the Gassaway; still farther northeast, in the area of the Wolf Creek Reservoir in Kentucky, the phosphatebearing beds are 5 to 8 feet thick (pl. 7, fig. 11). These phosphatic beds are not to be confused with a thin bed of closely packed phosphate nodules in the overlying Maury formation.

\section{DISTRIBUTION OF THE CHATTANOOGA SHALE}

As already mentioned, the black shales of Devonian and Mississippian age in North America are notable for their great extent (pl. 14). Within the part of the southeastern United States covered by this report the Chattanooga shale is also remarkable for its thinness. The distribution and the gradual changes in thickness of the formation are shown on plate 15 .

Ulrich (1911, p. 357) stated, without giving supporting evidence, that the Chattanooga shale "pinches out on the very gently sloping surface of the Nashville island of the time $* * *$," apparently referring to the region of the Nashville dome. This statement has been quoted and the conclusion adopted by some writers. Available evidence, however, indicates that some part of the Chattanooga shale covered nearly all the present Nashville dome (pls. 7, 15). The continuation of the formation across the present area of the Nashville Basin is indicated by the presence of the shale (a) at all examined outcrops along the northern edge of the Basin, (b) on many widely scattered outliers near the center of the Basin, some of which are close to the crest of the dome, and (c) on the abundant outliers across the southern part of the basin. On some of the outliers no measurable outcrops of the shale were found, but careful search of slopes consistently reveals 
fragments of the shale, and most road cuts at the right altitude show the shale.

One of the most interesting and significant known outcrops is on an outlier near the southeast corner of Williamson County (loc. 185), within about 10 miles of the axis of the Nashville dome. Here a $171 / 2$-foot exposure of Chattanooga shale shows about $51 / 2$ feet of strata of the Gassaway member overlying about 12 feet of beds of the Dowelltown member. A general thinning of the beds towards the crest of a Late Devonian arch, as indicated by plates $7,8,12$, and 15 and by figures 9 and 10, suggests that the arch was either rising slightly while the sediments were accumulating or was already slightly higher than the surrounding region. However, most of the Late Devonian arch, as well as the area of the present Nashville arch, was not an island during most of Chattanooga time.

With but few exceptions within the area of this report, about 40,000 square miles, the black shale is present wherever its position is exposed. The chief exceptions are two areas west and southwest of the Nashville Basin that existed as islands in the Chattanooga sea, and outlying areas in Alabama and Mississippi that may have been beyond the bounds of the Chattanooga sea (pl. 14); at these places the shale was not deposited or it was removed before deposition of the Maury formation.

One of the island areas where all the Chattanooga shale except the Hardin sandstone member is absent includes large parts of Lewis, Wayne, Lawrence, and Giles Counties, Tenn., and extends into northern Limestone County, Ala.; it is an irregularly shaped large area, here referred to as the Hohenwald platform. The shale thins to zero on the flanks of this ancient platform but the Maury formation covers the entire area. At the beginning of Gassaway time the platform may have been part of a great land area to the south that had not yet been submerged by the Chattanooga sea. During much of the time of Gassaway deposition the area must have been an island that was decreasing in size as the sea spread over more and more territory but, so far as can be determined, 1,500 squares miles still remained unflooded at the end of Gassaway time ( $\mathrm{pl}$. 12).

A second place where the Chattanooga shale is absent is in western Davidson County and eastern Cheatham County, Tenn. As shown on plate 15, two small, nearly adjacent islands seem to have existed during the deposition of the Chattanooga shale, but they too were later submerged so that the Maury formation blankets them both. Only a small amount of field data from this area supports these statements; further work would undoubtedly result in many changes in the hypothetical outline of these islands and provide a better basis for understanding their history. Though the manner of overlap is similar to that onto the Hohenwald platform, the rate of thinning toward these islands is surprising. For example, the Chattanooga is 28 feet thick at locality 198 but is absent 1 mile to the north across the Cumberland River at locality 197. Contrary to what might be expected, however, the lithologic character of the several Chattanooga units, where present here, is not notably different from that in other areas. It is possible that the shale was stripped from these "island" areas before the beginning of Maury time. If it was, diligent search might reveal one or more nearby outcrops where the Gassaway member is absent and part of the Dowelltown is present, a condition unknown at present in the Chattanooga shale.

Near the south and southwest limits of the region of this study, in Alabama and Tennessee, the Chattanooga shale is also absent at many places. This observation, however, is based almost entirely on information from widely scattered outcrops and wells, and the significance of the distribution is not understood. Along Red Mountain in the vicinity of Birmingham, Ala., the black Chattanooga shale is very thin or absent and presumably was not deposited to the east and southeast. However, about 27 miles southwest of Birmingham in Bibb County (E1/2 SE1/4 sec. 34, T. 21 S., R. 6 W.), a U.S. Bureau of Mines core revealed about 25 feet of Chattanooga shale. At the southwesternmost part of Red Mountain near Woodstock, Ala., about 5 miles south of the drill hole, the shale is only about 5 feet thick, yet some 15 miles farther south, at Pratts Bluff, about 5 miles northwest of Centreville, 17 feet of Chattanooga shale is present. The Pratts Bluff locality is the southernmost place where the Chattanooga was studied, and its proximity to a shoreline is suggested by abundant layers, lenses, and balls of sandstone, and by quartz sand and pebbles that are scattered through the layers of silty black shale. Thus, the southern limit of Chattanooga shale deposition is not actually known because it is beneath the Coastal Plain and opportunities for getting information on distribution of the shale are not good. In the Coastal Plain regions farther south the likelihood of finding the shale in drill holes is slight, even if it is present in the buried Paleozoic rocks that are an extension of the eroded and structurally complex folded Appalachian belt.

Sparse information from wells near the AlabamaMississippi State line suggests the shale was not deposited in most of Mississippi. Outcrops and fairly reliable data from wells in northeastern Tishomingo County, Miss., and southern Hardin County, Tenn., show the limit of the main body of the Chattanooga 
shale in that area. In 1955 Mellen called attention to Chattanooga shale in scattered wells in northeast Mississippi, but it is not known whether these are remnants of black shale that once blanketed the area or whether they represent irregular embayments into the land area.

So far as is known, the Chattanooga shale is absent beneath most of the Coastal Plain area of western Tennessee. This may result partly from Late Paleozoic or Mesozoic erosion, but much of this area may have been a part of the Ozarkian landmass that was supplying sediment to the Chattanooga sea.

Foerste (1901, p. 428-429) cited one locality near Rockdale, Maury County, Tenn., that suggested to him "erosion of Black shale during early deposition of the Waverly [Maury formation of this report]." Dunbar $(1919$, p. 92$)$ stated "in the Western Valley [the Chattanooga shale] is uniformly thin and locally absent at many places, apparently due to later erosion." Swartz $(1924$, p. 29) apparently believed that the thinning and absence of the Chattanooga shale beneath the "invariably present" Maury formation in western Tennessee are the result of partial or complete erosion of the Chattanooga shale and hence are evidence for a marked unconformity. As already indicated, however, in most places the absence of the shale is the result of nondeposition rather than of pre-Maury erosion.

Morse (1930, p. 54) described an unconformity "of great magnitude" in Tishomingo County, Miss., separating his Whetstone Branch shale (Chattanooga shale) from his Carmack limestone (partial equivalent of the Ridgetop shale and Fort Payne chert, having the Maury formation as a basal unit). He based his conclusion on two lines of reasoning: He described a conspicuous "basal conglomerate" of the Carmack limestone, which is, in reality, a bed of large phosphate nodules embedded in glauconitic sandstone-typical of the Maury formation in northeastern Mississippi and nearby areas in Tennessee and Alabama; he also described the Carmack as lying, in different areas, on several different formations including his Whetstone Branch shale. This overlap by the Maury apparently results not from erosion of the black shale, as suggested by Morse, but from lack of deposition of the shale.

According to Jewell (1931, p. 37-42), an unconformity separates the Chattanooga shale from the overlying Ridgetop shale in Hardin County, Tenn. To understand his reasons for this interpretation, the following stratigraphic units and their relationships must be presented, as used by Jewell: A "Maury glauconitic member" is assigned to the Chattanooga shale, this member being recognized at only four localities in the county; the next younger unit is the Ridgetop shale which, with the exception of the four localities, he described as overlying the black shale or the Hardin sandstone (also a member of the Chattanooga shale). Apparently the supposed absence of the Maury is Jewell's reason for placing an unconformity between his Chattanooga (our Maury formation) and the Ridgetop, although he stated (p. 39) that the absence of the black shale of the Chattanooga is also indicative of the erosion interval. The confusion of stratigraphic units and the resulting interpretation of erosion can be resolved merely by pointing out that Jewell placed the Maury formation of this report with the Chattanooga shale at four localities and in the lower part of the Ridgetop at all other localities. The latter assignment is understandable because the true identity of the Maury is masked by its gradation into the overlying Ridgetop. At every outcrop we studied during this investigation, in Hardin County and elsewhere, the Maury was present at its normal position.

Campbell (1946, p. 896-900) described erosion intervals near the close of Chattanooga time and shortly thereafter. He assumed a complex regressing and transgressing shoreline to explain the presence and absence of one or more very thin beds separating the main part of the Chattanooga shale from the formation overlying the Maury. Whether or not such thin units are everywhere present or are in part absent, the fact remains that such a delicate pattern of subaerial erosion as called for by Campbell is unlikely. The lithologic variations within the Maury can be more plausibly explained by assuming local or regional submarine hiatuses or by merely assuming that different lithologic facies are present.

\section{COMPOSITION OF THE CHATTANOOGA SHALE}

Quantitative determination of the mineral composition of the shale is extremely difficult because of the fine grain size of the rock and the masking effect of the abundant organic matter. Chemical analyses of several samples of the shale have shown the amount of pyrite and organic matter in the rock and have served to check the estimates made from study of thin sections. As each chemical analysis is of a sample that represents a thickness of about 2 feet, it is somewhat more indicative of the bulk composition of the shale than is a thin section, which represents an inch or less of the shale. Rough estimates of the mineral composition were made from several thin sections, and one of the chemical analyses was recalculated in a manner consistent with known facts about the shale. Detailed studies at Pennsylvania State College under the direction of Dr. T. F. Bates of the mineralogy of a core of the Chattanooga shale from near Smithsville, Tenn., showed that the chief clay mineral is illite, or hydro- 
mica, which constitutes somewhat less than 10 percent of the black shale samples but 15 percent or more of the gray claystone beds (Strahl and others, 1954, p. 38-39).

\section{Chemical DeTerminations}

Chemical analyses of samples of typical massive black shale of the upper unit of the Gassaway member of the Chattanooga shale in Tennessee are shown in table 5. The shale of sample $C$ is believed to be the least weathered and therefore should have provided the best analysis.

TABLE 5.-Chemical analyses of outcrop samples of Chattanooga shale in Tennessee

[A, from loc. 60; Gassaway member, probably the uppermost 2 feet; collected by K. G. Brill and others. B, from loc. 54; Gassaway member, probably 4 or 5 feet of the upper part; collected by $A$. L. Slaughter and others. $C$, from loc. 92; a 2-foot sample taken 3.7-5.7 feet below base of the Maury formation. Analyses are by Battelle Memorial Institute, Columbus, Ohio. Used by permission of U.S. A tomic Energy Commission]

\begin{tabular}{|c|c|c|c|}
\hline & \multicolumn{3}{|c|}{ Sample } \\
\hline & $A$ & $B$ & $C$ \\
\hline $\begin{array}{l}\text { Ignition loss. } \\
\text { SiO }_{2}\end{array}$ & $\begin{array}{r}23.4 \\
46.00\end{array}$ & $\begin{array}{r}24.9 \\
48.60\end{array}$ & $\begin{array}{r}23.0 \\
49.30\end{array}$ \\
\hline $\mathrm{Al}_{2} \mathrm{O}_{3}$ & $111.60^{-}$ & 110.40 & 10.71 \\
\hline $\begin{array}{l}\mathrm{Fe}_{2} \mathrm{O}_{3} \\
\mathrm{MgO}\end{array}$ & 10.70 & 9.90 & $\begin{array}{l}9.60 \\
1.22\end{array}$ \\
\hline $\mathrm{CaO}$ & 1.46 & .21 & .36 \\
\hline $\mathrm{N}_{2} \mathrm{O}_{2}$ & (8) 39 & (3.40 & $\begin{array}{r}.33 \\
4.03\end{array}$ \\
\hline $\mathrm{P}_{2} \mathrm{O}_{5}$ & .96 & .27 & .12 \\
\hline $\mathrm{CO}_{2}$ & 6.80 & .100 & $\begin{array}{r}3.31 \\
6.90\end{array}$ \\
\hline C. & 14.50 & 14.60 & 14. 30 \\
\hline H & & 1.00 & \\
\hline Total & 98.56 & 95.16 & 99.42 \\
\hline
\end{tabular}

1 Includes $\mathrm{TiO}_{2}, \mathrm{ZrO}_{2}, \mathrm{~V}_{2} \mathrm{O}_{5}$.

${ }_{3}^{3}$ Separate analyses give: 0.8 percent organic sulfur; 0.3 percent sulfate sulfur; 5.7 percent pyrite sulfur $\left(=10.7\right.$ percent $\left.\mathrm{FeS}_{2}\right)$.

In table 6 the average analyses of shales and graywackes are compared with sample $C$ of table 5. The analysis of sample $C$ includes the large amount of substances lost on ignition, so column $D$ of table 6 was prepared to facilitate comparisons. Although the average analyses of the shales and graywackes include some constituents that are lost by ignition, those substances are sufficiently small in the graywackes that their presence does not appreciably affect the relative quantities of the other important constituents for purposes of rough comparisons.

Comparison of column $D$ with columns $A$ and $B$ shows that, except for the high iron content, the black shale has a chemical composition much like that of a quartz-rich detrital sedimentary rock. The abnormally small quantities of $\mathrm{MgO}$ and $\mathrm{CaO}$ in the black shale doubtless result from the acidic conditions on the sea bottom, which hindered precipitation of those substances.

The investigations of the mineralogy of the shale that were made at Pennsylvania State University
TABLE 6.-Chemical composition of shales and graywackes

$[A$, Composite analysis of 51 Paleozoic shales; adapted from Clarke (1924, p. 552). $B$, A verage graywacke; adapted from Pettijohn, (1949, p. 271). C, Chattanooga shale, same as sample $C$ in table 5. $D$, Same as $C$, after reca!culating for ignition loss]

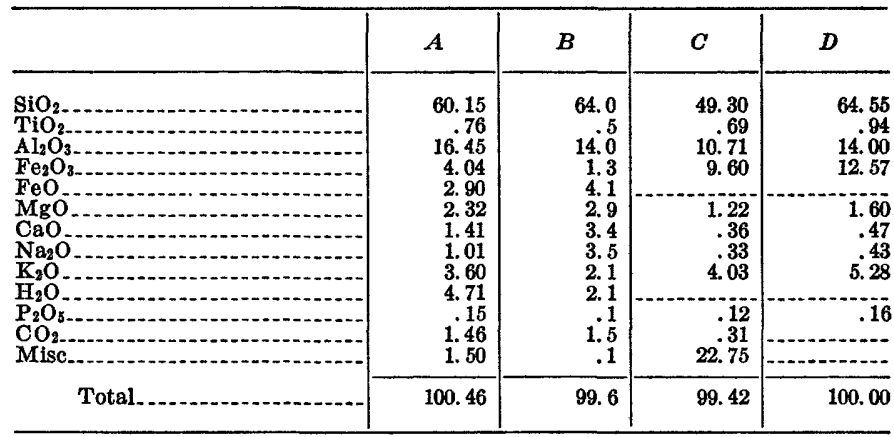

(Bates, 1953 ; Bates and others, 1953; Strahl and others, $1955)$ included chemical analyses and studies with light and electron microscopes and with electron and X-ray diffraction and other equipment. These studies showed that the denser and darker parts of the shale, which contain the most uranium, have the approximate composition shown in table 7 .

TABLE 7.-Mineralogic composition of the more uraniferous parts of the black shale

[Analysis by Pennsylvania State University] $\begin{gathered}\text { Weight } \\ \text { (percent) }\end{gathered}$

Quartz -

Feldspar -_. 10

Clay and mica -

Pyrite - -

Organic -..... 15-20

Other _...

Another study at Pennsylvania State University (Kinney and others, 1957, p. 14) of the organic matter in the black shale of the Chattanooga led to the conclusion that the organic content of the rock ranges from 19.6 to 20.5 percent.

\section{PETROGRAPHIC DETERMINATIONS}

The following generalities are drawn from study of thin sections of rocks in the Chattanooga shale: (a) The chief detrital mineral grains of the massive black shale are silt-size quartz and somewhat smaller amounts of clay and mica, and these grains are well sorted; (b) the gray claystone is finer grained than the black shale, contains larger amounts of clay and smaller amounts of quartz, and is poorly sorted; (c) amber-colored ellipsoidal spore cases and other plant matter, much of which is shredded, are disseminated throughout the black shale and are concentrated locally in some of the layers; (d) the quartz-rich parts of the formation contain most of the organic matter. 
An obvious characteristic of the black shale beds of the Chattanooga shale, especially the more massive beds in the Gassaway member, is the extremely fine grain size of most of its constituents. Grains of practically all the minerals range from silt-size particles downward to the limit of visibility with a light microscope. Under these conditions it is obviously difficult to determine the identity of many of the grains, more so to calculate their proportions. The studies at Pennsylvania State University (Bates, 1953; Strahl and others, 1954, p. 31) showed that some of the grains that appear to be quartz are feldspar. Minute mica flakes large enough to be recognized by the naked eye are scattered throughout the shale, especially in those parts that are best stratified. Miscroscopic masses of phosphate are present in much of the shale, even in those parts that do not show nodules on the outcrop. Calcite, though constituting only a small fraction of 1 percent, is observed in thin sections as widely scattered single crystals or minute lenses. Zircon is present as sparsely scattered tiny grains. In volume the light-weight organic matter, present as films and masses, is roughly estimated to constitute about a third of the rock; this volume is consistent with the 15 to 20 percent organic matter by weight that has been found by other studies.

One of the most strikng microscopic characteristics of the seemingly nearly massive black shale is a wellmarked lamination that results from a high degree of sorting of the grains (pl. 11). Many paper-thin laminae are composed almost solely of quartz and have sharp upper and lower boundaries. Adjoining laminae have various mixtures of other constituents.

In general the most massive and densest shale of the Chattanooga, chiefly in the Gassaway member, is extremely fine-grained argillaceous quartz siltstone, rich in organic matter and pyrite. The fissility of this black shale when weathered is clearly the result of the high degree of sorting and lamination. By contrast, the shale of the lower unit of the Dowelltown member, which is somewhat less massive in the outcrop, is less well sorted and has fewer of the paper-thin laminae of quartz.

The gray beds of the upper unit of the Dowelltown member are finer grained than the black shale and contain more clay. Thin-section study indicates that clay, or some other equally fine-grained mineral, constitutes about 65 percent of the rock; recognizable quartz, pyrite, and organic matter about 10 percent each; and mica, calcite, and zircon much smaller amounts. The organic matter is more abundant in the layers that contain the most quartz and is relatively sparse in the clayrich beds. In contrast with the black shale beds, the gray beds have mineral grains of less parallelism and the lamination is poor. These clay-rich beds, which are poorly laminated and nonfissile, may appropriately be called claystone.

The black beds between the gray beds of the upper unit of the Dowelltown contain quartz whose average grain size appears to be somewhat greater than that of the quartz in the gray beds. The grains in the black beds are much better sorted than those in the gray beds but are not as well sorted as those in the more massive black shale of the Gassaway member.

The sandstone in the Hardin sandstone member, as seen in thin sections of two typical samples from Olivehill and Waynesboro, Tenn. (locs. 238 and 243), is composed dominantly of fine-grained quartz. Most of the quartz grains range in average diameter from 0.02 to $0.1 \mathrm{~mm}$, though at Olivehill some are appreciably larger. Feldspar grains, recognizable by albite and microcline twinning, are scattered throughout but probably constitute less than 1 percent of the rock. Glauconite and phosphate are likewise sparsely scattered through the sections. Calcite makes up a quarter to a third of the Waynesboro sample and is apparently a secondary cement. Pyrite grains are scattered throughout but constitute hardly more than 1 percent. A few small fragments of fossils are also present. The quartz grains are poorly rounded, and many of them have acute-angled corners. In general, the larger grains seem to be somewhat more angular. The thin sections show the same uniformity of grain size and lack of bedding that characterize the outcrops.

The sandstone at the base of the Chattanooga-Maury sequence, which ranges in age from earliest Dowelltown to Maury, varies greatly in composition and grain size from place to place. The sandstone generally contains quartz, chert, phosphatic remains of assorted fossils, pyrite, and calcite, all in widely varying proportions and sizes. The fossils consist of shell fragments from the underlying formations, many of them phosphatized, of angular and rounded fragments of bone, and of fragmentary conodonts. Calcite is commonly secondary and encloses other ingredients. Feldspar grains showing microcline twinning are common but make up less than 1 percent of the rock. Widely scattered grains of glauconite are present in some samples. Zircon is sparsely present as small scattered grains.

Where no Chattanooga shale is present and the Maury formation rests on the pre-Chattanooga rocks, the basal sandstone is commonly rich in glauconite and phosphate. The phosphate consists both of transported (allogenic) fragments reworked from the underlying land surface and of masses that enclose detrital grains of the sandstone and have obviously formed in place (authigenic). 
Thin beds of sandstone are common in the Dowelltown member and locally are present in the Gassaway member. Most of these beds are a small fraction of an inch thick, but locally they are thicker; in a few places they make up a significant part of the member or the formation. Most of the sandstone beds in the shale are composed chiefly of poorly rounded quartz and varying amounts of chert, pyrite, and calcite. Widely scattered grains of glauconite are commonly present. Phosphate is also present as rounded fragments of bone and undetermined objects and as irregular masses. Feldspar grains that can be recognized by albite and microline twinning make up less than 1 percent of the rock. Zircon and other heavy minerals are sparsely scattered.

The Bransford sandstone bed at the base of the Gassaway member along the northwestern edge of the Nashville Basin is composed chiefly of fine to medium quartz sand but contains many fossils, notably conodonts, bone fragments, teeth, and phosphatized parts of Cyclora-like gastropods.

The "varved" bed at the base of the middle unit of the Gassaway member consists chiefly of quartz, together with mica, clay, spores, and other organic matter. The concentration of the organic matter in layers gives the rock its banded or varved appearance. Zircon grains, though small, are fairly abundant. Most of the quartz grains are between 0.008 and $0.07 \mathrm{~mm}$ in diameter, much the greater part of them being in the size range of silt (less than $0.062 \mathrm{~mm}$ ).

In Hardin and Wayne Counties, Tenn., and in nearby parts of Perry County, Tenn., and Tishomingo County, Miss., the Chattanooga shale is chiefly a calcareous and phosphatic quartz sandstone having thin layers of black shale. Morse (1930) recognized the equivalence of these beds with the Chattanooga shale but proposed the term Whetstone Branch formation for them (p. 18). A thin section of typical calcareous sandstone from Morse's type locality along Whetstone Branch (loc. 235) shows poorly sorted and poorly rounded quartz sand having abundant fragments of phosphatic fossils of many types. Pyrite is irregularly distributed, chiefly as interstitial fillings. Feldspar, showing albite and microcline twinning, makes up 1 to 2 percent of the thin section.

More details concerning the size, shape, and other characteristics of the constituents of the shale are given in the following paragraphs, in which the individual minerals are discussed separately.

\section{QUARTZ}

Extremely fine grained quartz is the major constituent of the black shale beds of the Chattanooga and probably makes up about 20 to 25 percent of the rock. Partings of quartz silt are visible throughout the formation, and petrographic examination shows even thinner partings to be especially characteristic of what appears on the outcrop to be the most massive part of the formation (pl. 11A). Within the densest black shale are microscopic layers, commonly less than 0.1 $\mathrm{mm}$ thick, composed of quartz grains ranging from 0.02 to $0.06 \mathrm{~mm}$ and averaging about $0.03 \mathrm{~mm}$ in greatest diameter. Still finer quartz ranging in diameter from about 0.004 to $0.012 \mathrm{~mm}$ and averaging $0.008 \mathrm{~mm}$ is disseminated fairly uniformly throughout the massive shale. For ease of comparison, it may be pointed out that the coarser grains mentioned( those averaging $0.03 \mathrm{~mm}$ in diameter) are about one-third as thick as a sheet of common letter paper, and the grains $0.008 \mathrm{~mm}$ in size are about one-third as thick as the tissue sheets commonly used for carbon copies of letters. It may be truly said that the laminae in the shale are paper thin!

The investigations of the mineralogy of the Chattanooga shale at Pennsylvania State University (Bates and Strahl, 1957, p. 1307) revealed quartz that is far below the range of ordinary microscopic visibility. In the course of that work, small amounts of quartz were found in the 0.4-micron fraction but not in the 0.3micron fraction.

In general, the quartz grains are typical sand grains that show various degrees of roundness but few other characteristics indicative of their history. No solution pits were observed that would suggest slow solution in the soil on the old land surface, and no crystal outlines were noted that would suggest the grains originated as tiny euhedral crystals in the nearby limestones. Secondary growth was seen on a few grains of a sandstone layer from the shale in Lawrence County, where the formation is only 2 feet thick (loc. 151), but otherwise no post-depositional alteration of the quartz grains was observed. Seemingly, most of the quartz grains in the shale have experienced repeated cycles of normal sedimentation and are lacking in such indicative features as excessive angularity, marked roundness, solution cavities, or secondary growth. Regardless of their history, of course, the fine silt and clay grains would not show these features.

At a few places we saw quartz veins as much as 2 and 3 inches wide in the Chattanooga shale. Because of talus, they were seen no place where their downward extent could be determined, but they were observed to pinch out at or near the top of the shale. The quartz crystals are elongated perpendicular to the walls and appear to have grown toward the center of an open crack, filling the space only imperfectly. 
MICA

Freshly broken surfaces of the shale commonly show reflections from minute micaceous grains that may be muscovite, sericite, or hydromica. Study of several thin sections indicates that the mica content is about 5 to 10 percent. The range in grain size is relatively small, nearly all the mica flakes having greatest diameters between about 0.01 and $0.06 \mathrm{~mm}$ and most of them between 0.025 and $0.035 \mathrm{~mm}$. The flakes are aligned almost perfectly with the stratification and are well distributed throughout the rock.

Abundant black mica resembling biotite was observed in fresh samples of the thin Center Hill bentonite bed that is in the upper part of the Dowelltown member of the Chattanooga shale. When exposed to weathering, the black mica in the bentonite becomes almost colorless and resembles muscovite or sericite in appearance. Workers at Pennsylvania State University (Strahl and others, 1954, p. 8-9) believed that the biotite alters to kaolinite. Except in this thin bed of bentonite, biotite was not seen in the Chattanooga shale, but Geological Survey laboratory mineralogical and chemical studies (Deul, 1957, p. 215) of samples of the massive black shale of the upper part of the Gassaway member have shown that biotite is present in quantities estimated at 1 percent.

\section{CLAY}

The studies at Pennsylvania State University of the mineralogy of a core of the Chattanooga shale (Bates and Strahl, 1957, p. 1308), showed that the chief clay mineral is illite but that some kaolinite is also present. Chemical studies of 60 samples chosen at random from the core indicated that the clay content of the "blackest" unit of the shale is only about 7 percent and that the highest clay content of any of the recoguized lithologic units of the formation is only about 16 percent. Only one sample contains more than 20 percent clay. These findings (Strahl and others, 1954, p. 38-39) are summarized in table 8.

TABLE 8.-Clay content of Chattanooga shale [Adapted from Strahl and others, 1954]

\begin{tabular}{|c|c|c|c|c|}
\hline \multirow{2}{*}{ Stratigraphic unit } & \multirow{2}{*}{$\begin{array}{l}\text { Thick- } \\
\text { ness } \\
\text { (feet) }\end{array}$} & \multirow{2}{*}{$\begin{array}{c}\text { Number } \\
\text { of } \\
\text { samples }\end{array}$} & \multicolumn{2}{|c|}{ Clay content (percent) } \\
\hline & & & Range & Mean \\
\hline $\begin{array}{l}\text { Gassaway member: } \\
\text { Upper unit } \\
\text { Middle unit } \\
\text { Lower unit }\end{array}$ & $\begin{array}{l}6.5 \\
2.6 \\
8.7\end{array}$ & $\begin{array}{r}12 \\
4 \\
15\end{array}$ & $\begin{array}{r}4.40-9.37 \\
8.94-15.50 \\
6.98-14.85\end{array}$ & $\begin{array}{r}7.08 \\
12.11 \\
9.71\end{array}$ \\
\hline $\begin{array}{l}\text { Dowelltown member: } \\
\text { Upper unit } \\
\text { Lower unit } \\
\text { Chattanooga shale (entire formation). }\end{array}$ & $\begin{array}{r}11.0 \\
7.2 \\
36.0\end{array}$ & $\begin{array}{l}15 \\
14 \\
60\end{array}$ & $\begin{array}{r}10.15-21.40 \\
4.15-19.14 \\
4.15-21.40\end{array}$ & $\begin{array}{l}15.87 \\
11.56 \\
11.44\end{array}$ \\
\hline
\end{tabular}

\section{FEUDSPAR}

The sandstone layers of the shale commonly contain sparsely scattered grains of feldspar that are readily recognized by their albite or microcline twinning. The grains are about the size of the associated quartz grains and are clearly of detrital origin. In none of the thin sections we studied does the easily identifiable feldspar make up as much as 1 percent of the rock. Feldspar is not readily recognizable in the thin siltstone laminae or other parts of the massive black shale.

The Pennsylvania State University studies (Bates and Strahl, 1957, p. 1307, 1312) show the presence of orthoclase, plagioclase, and sanidine feldspars in the massive black shale that constitutes the upper unit of the Gassaway member. Feldspar makes up about 9 percent of the rock. Orthoclase is the most abundant feldspar and "**** commonly shows distinct crystal outlines suggesting authigenic origin." Many of the other feldspar grains also have authigenic overgrowths.

\section{PYRITE AND MARCASITE}

Laboratory investigations of the Chattanooga shale have shown that both pyrite and marcasite are present. The marcasite, however, constitutes only about 2 percent of the sulfide in the shale (Bates and Strahl, 1957, p. 1308). Iron sulfide generally is referred to as pyrite in this report.

Pyrite is common in the black shale and ranges in size from submicroscopic cubes less than 0.15 micron on a side (Bates, 1953) to crystalline spherulites and lenses as much as an inch thick. Most of it is present as microscopic lumps of irregular shape and as spherules as small as $0.02 \mathrm{~mm}$ in diameter, but larger nodules of fine-grained pyrite, about 4 to $6 \mathrm{~mm}$ in diameter, are liberally scattered through the shale. Many spores are filled and surrounded by pyrite. The pyrite visible to the naked eye is commonly concentrated in layers ranging in thickness from thin and discontinuous films to nodular masses as much as an inch thick, around which the shale has been warped. Some of the pyrite visible to the unaided eye shows distinct crystal faces.

The minute spherules of pyrite probably formed during or shortly after black mud deposition, but the larger masses may have resulted from short-distance migration of the sulfurous compounds while the muds were still unconsolidated. Many siltstone and sandstone beds within the shale are markedly pyritic and locally these beds have cavities encrusted with pyrite crystals. 
Along the northern edge of the Nashville Basin a pyrite-rich siltstone bed in the lower 2 to 4 feet of the Gassaway member seems to be a traceable lithologic unit. The bed is commonly about 2 to 3 inches thick, contains roughly 50 percent pyrite, and weathers to a soft and friable material coated with yellow and white sulfate blooms. This bed can be traced at least 50 miles from western Davidson County to central Macon County. Because it seems to indicate a unique set of chemical and physical conditions in the Chattanooga sea, which is not recognized elsewhere in the section, this bed is believed to be a time marker.

The pyrite in the shale breaks down readily upon exposure and forms several secondary minerals. In some places the pyrite yields a distinct "bloom" of yellow and white crystals that were identified by Charles Milton (Milton and others, 1955) of the Geological Survey as copiapite (a yellow hydrous ferric sulfate), coquimbite (a white granular hydrous ferric sulfate), and halotrichite (a finely fibrous white hydrous ferrous aluminum sulfate). Minute gypsum crystals are seen commonly on joint faces or bedding planes along which water has been able to seep.

\section{PHOSPHATE}

Phosphate is present in the Chattanooga shale both as detrital grains (allogenic) and as a chemical precipitate (authigenic). The detrital grains represent two types of sources: One type is made up of reworked fragments of bones, shells, and undetermined objects from the older rocks; the other type consists of phosphatic bones, shells, conodonts, or other parts of organisms that lived in the Chattanooga sea or drifted into it.

The most notable example of the detrital type is the "blue phosphate" in Perry, Hickman, Lewis, and Maury Counties where residual matter from the Leipers limestone of Ordovician age has been reworked into an unusual type of sandstone at the base of the Chattanooga. Smith and Whitlatch (1940, p. 302) reported that the "blue phosphate" is composed chiefly of the mineral collophane, together with various amounts of fibrous dahllite, pyrite, quartz, chalcedony, and shaly material. In the southwest part of the area that was studied for this report, especially in Wayne and Hardin Counties, Tenn., and in Tishomingo County, Miss., much of the lower part of the Chattanooga shale is an impure phosphatic black sandstone. Studies of thin sections show that reworked small phosphatic particles are also scattered throughout the formation and are especially abundant in the sandstone beds.
The chemical precipitates of phosphate are nodules or plates that are common in the upper few feet of the Chattanooga shale, chiefly in the northern part of the area studied. They are by no means as abundant as in the immediately overlying Maury formation but are scattered through one or more beds. The nodules are subspherical or discoidal in shape, commonly about 1 to 3 inches thick. The plates are typically somewhat less than an inch thick but are as much as several feet long. Most of the nodules and plates are parallel to the bedding of the shale, but some cut across the beds at different angles. Some of the nodules appear to have pushed the beds aside, but in part they also cut out the beds. When broken open a large number of the nodules are found to have at or near the center an organic object, such as a shell, conodont, or bone fragment (for example, Maher and Dunkle, 1955).

Whether the nodules in the black shale formed on the surface of deposition and were buried later, took shape in the sediment very soon after deposition, or even formed after the shale had been compacted is, in many instances, uncertain. Such criteria as termination of the laminae against the nodule or bending of the laminae around the nodule can be used to ascribe syngenetic, diagenetic, and epigenitic origins to these nodules.

\section{PLANT MatTher}

As already pointed out (p. 19), thin layers of coaly material are seen occasionally in the shale and have been mistaken for bitumen. Breger and Schopf (1955) stated that the material is vitrain corresponding in rank to high-volatile A bituminous coal. They gave the analyses of a bed of this material that is half an inch or more thick (table 9).

TABLE 9.-Analyses of vitrain from the Chattanooga shale [Analyses by U.S. Bureau of Mines, lab. rept. E-32291, Feb. 2, 1954. Sample from loc. 203B, Davidson County, Tenn.]

\begin{tabular}{|c|c|c|c|}
\hline & As received & $\begin{array}{c}\text { Moisture } \\
\text { free }\end{array}$ & $\begin{array}{l}\text { Moisture- } \\
\text { and ash- } \\
\text { free }\end{array}$ \\
\hline $\begin{array}{l}\text { Proximate analysis: } \\
\text { Moisture }\end{array}$ & \multirow{7}{*}{$\begin{array}{r}2.1 \\
40.6 \\
55.1 \\
2.2 \\
5.6 \\
77.1 \\
1.7 \\
9.8 \\
3.6 \\
2.2 \\
14,340\end{array}$} & \multirow[b]{2}{*}{56.3} & \multirow[b]{2}{*}{$\begin{array}{r}42.7 \\
57.6\end{array}$} \\
\hline $\begin{array}{l}\text { Volatile matter } \\
\text { Fixed carbon.......... } \\
\text { Ash }\end{array}$ & & & \\
\hline Ultimate analysis: & & & \multirow{4}{*}{$\begin{array}{r}5.6 \\
80.5 \\
1.7 \\
8.5 \\
3.7\end{array}$} \\
\hline $\begin{array}{l}\text { Hydrogen.....- } \\
\text { Carbon....... }\end{array}$ & & $\begin{array}{r}5.5 \\
78.7\end{array}$ & \\
\hline Nitrogen & & 1.7 & \\
\hline $\begin{array}{l}\text { Oxygen } \\
\text { Sulfur }\end{array}$ & & $\begin{array}{l}8.2 \\
3.6\end{array}$ & \\
\hline Btu Ash & & $\begin{array}{r}2.3 \\
14,640\end{array}$ & 14,990 \\
\hline
\end{tabular}

The half-inch of coal at locality $203 \mathrm{~B}$, which appears to contain parts of several stems, is unusually rich in uranium (0.033 percent) and germanium 
(0.051 to 0.057 percent) and other metals. As it seems unlikely that the plant matter acquired so much germanium from the sea water, Breger and Schopf suggested that the plants acquired the germanium before they were floated into the sea, then absorbed the uranium from the sea water. It is probable that the shale contains no true bitumen but that all asphaltic or bitumenlike material in the shale is coalified plant matter or, more rarely, the carbonized remains of fossil fish.

\section{OTHER CONSTITUENTS}

At many outcrops hydrochloric acid was applied systematically to all beds to test for calcite. A slight observable reaction on a few thin beds indicates that a small amount of calcite is present at some localities, but most of the shale shows no reaction on the freshly broken surface, and the chemical analyses of the black shale indicate that calcite is uncommon. In thin sections of the black shale only a few scattered grains of calcite were seen, and in thin sections of the gray claystone a few discontinuous tiny lenses of calicte or dolomite were seen. Calcite is fairly common at many places in the lower 2 or 3 feet of the shale and in many of the sandstone beds of the formation. Secondary calcite forms a coating on some of the joint surfaces.

In the southwestern part of the area the impure and phosphatic shale is somewhat calcareous, especially in the lower sandy units.

In central Kentucky the lower 10 to 15 feet of the Chattanooga shale contains several layers of calcareous siltstone as much as 6 inches thick. Farther south, in Sumner and Trousdale Counties, Tenn., is the somewhat calcareous basal shale (p. 18) that Pohl thought should be considered a separate formation. In general, throughout the area of these studies, calcareous impurities are fairly common in the lower part of the shale but are uncommon in the higher part.

Chert grains are common in the sandstone at the base of the Chattanooga shale. The grains doubtless were weathered from the older limestones and later concentrated into the relatively coarse detritus at the base of the Chattanooga shale. Secondary chert is common in all the sandstone beds that were studied in thin section and is presumed to have formed soon after the detrital grains accumulated.

Chalcedony was reported (Smith and Whitlatch, 1940 , p. 302) as a cementing ingredient in the "blue phosphate."

Chlorite was detected by X-ray study at Pennsylvania State University (Weaver and others, 1952, p. 5; Bates and others, 1953, p. 31), though it has not been observed otherwise. It constitutes a part of that group of miscellaneous minerals that make up less than 5 percent of the shale.

Glauconite is a minor constituent in all the sandstone beds that have been studied but is absent or rare in the shale and its associated siltstone laminae.

Tourmaline and zircon were reported by investigators at Pennsylvania State University (Weaver and others, 1952 , p. 19) to be fairly common accessory minerals. The tourmaline grains are about 0.03 to $0.05 \mathrm{~mm}$ in length and the zircon about 0.01 to 0.02 $\mathrm{mm}$ in length. A few of these grains can be seen in almost any thin section of the formation, but nowhere are they known to be at all concentrated. They make up only a small fraction of 1 percent of the rock.

Single galena crystals 1 to $2 \mathrm{~mm}$ in diameter were observed at two outcrops of the black shale (locs. 54, 84). Their origin in the shale is unknown, but it seems likely that they were formed in the muds, as was the pyrite.

\section{PALEOGEOGRAPHY DURING LATE DEVONIAN TIME}

The Late Devonian sea spread far beyond the bounds of the area studied for this report (pl. 14), and any full discussion of the origin of the sediments necessarily includes the wider area. Northern Alabama, Tennessee, and southern Kentucky seem to have been close to the southeastern limit of the sea, and the sources of the sediments appear to be fairly definitely known. Figures 12 and 13 are interpretations of land and sea areas during Late Devonian time. From the land-sea relations shown in those figures and from knowledge of the thicknesses of shale and other sediments deposited in the different parts, some general deductions can be made concerning the various sources and the relative quantities that they contributed.

\section{REGIONAL TECTONIC INFLUENCE}

Central Tennessee is fully 400 miles southwest of the center of thickest sediment accumulation in eastern West Virginia, where at least 10,000 feet of sedimentary rocks of Middle and Late Devonian age are known. From this area of maximum thickness, these rocks thin at a fairly constant rate along any 300mile line of radius that trends between north-northwest and south-southwest. Beyond this 300-mile radius is a vast region extending westward to the Mississippi River where Upper Devonian rocks, predominantly black shale, average about 100 feet in thickness. Thus during Late Devonian time the greater part of the eastern United States consisted largely of three major tectonic elements: a geosyncline, its complementary landmass to the east, and an 


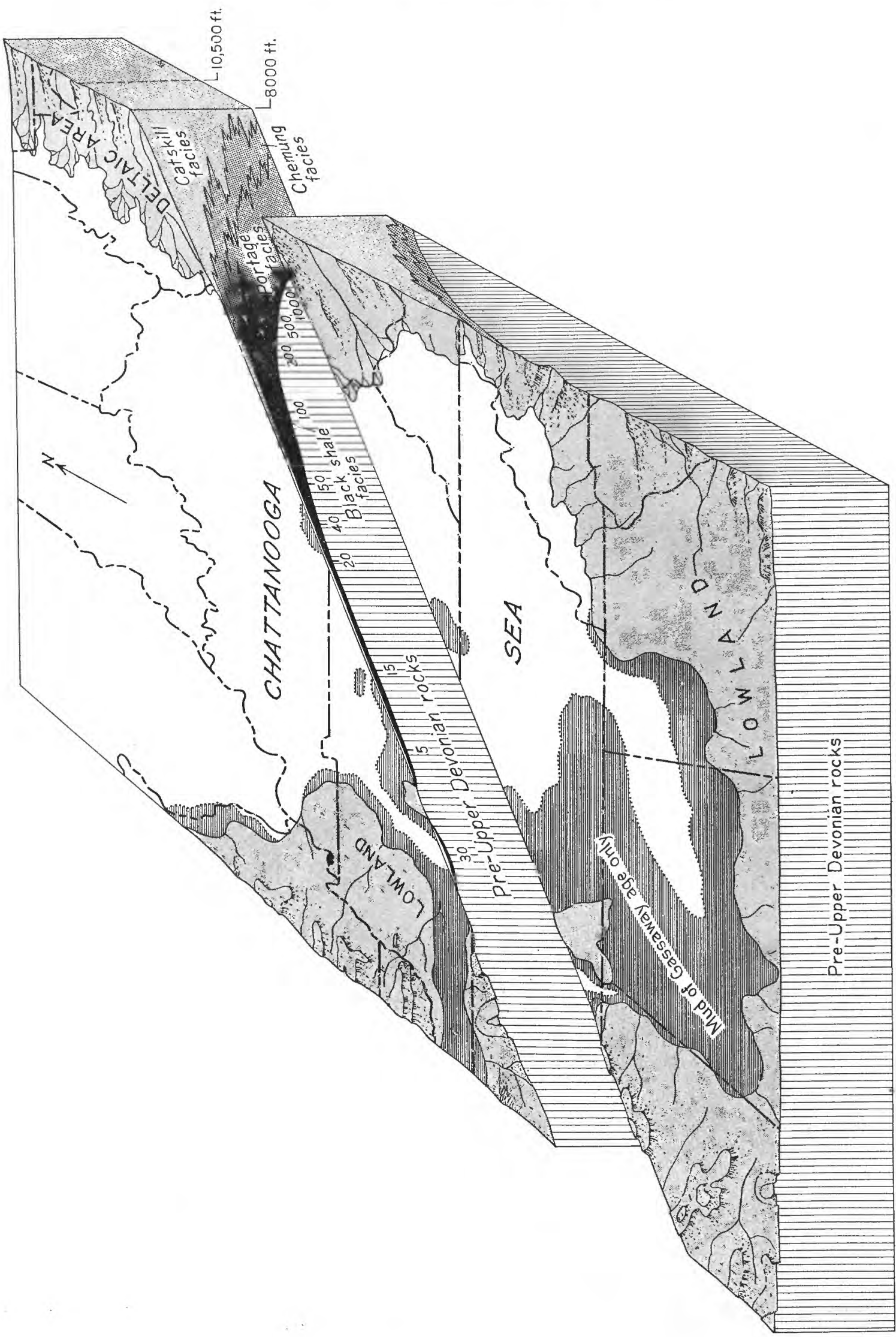




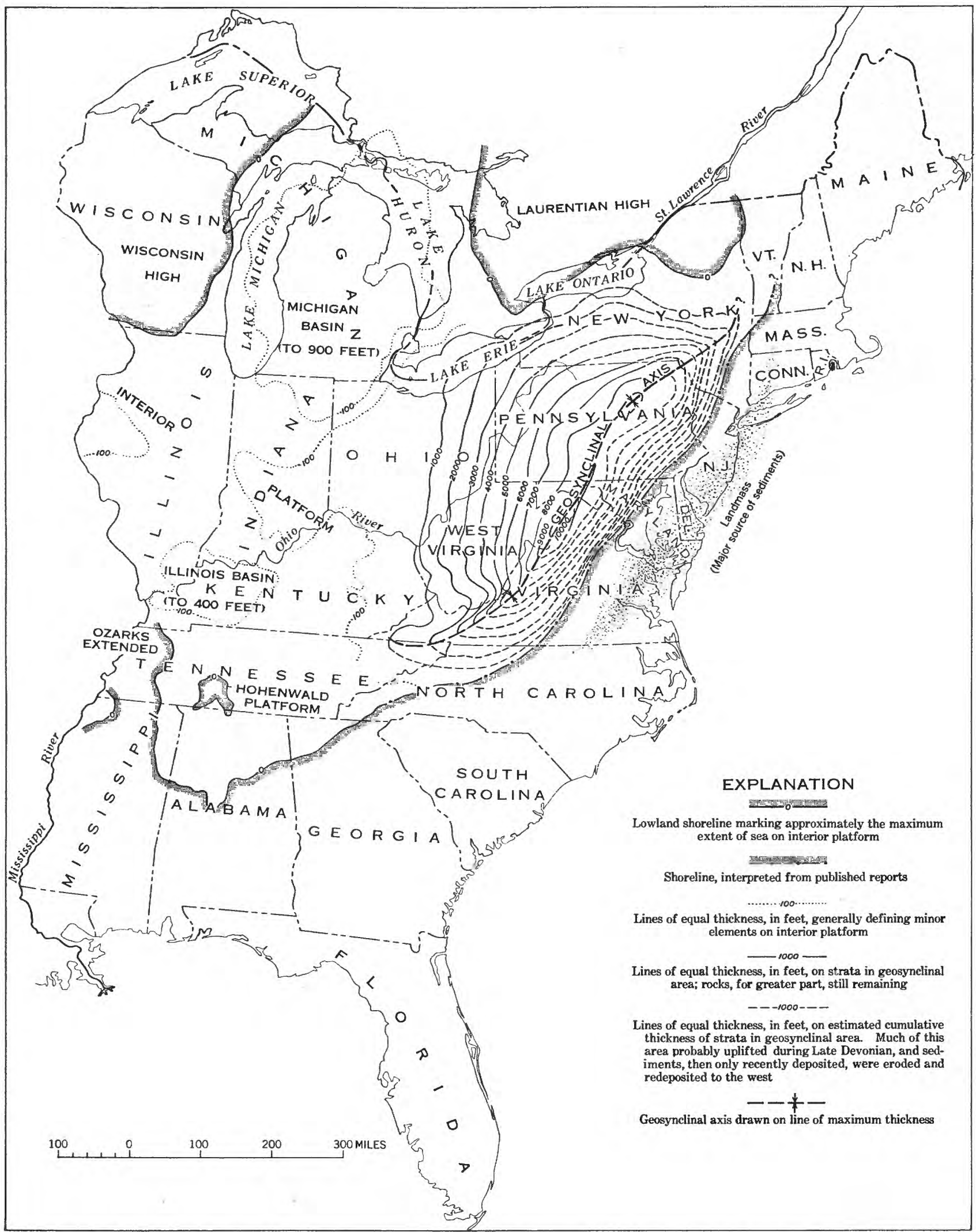

Figurn 13.-Map outlining paleotectonic and paleogeographic features in the eastern United States near the end of the Devonian, based on generalized thickness and distribution of the rocks. 
interior platform. Each of these elements is shown on figure 13.

\section{GEOSYTCLINE}

A detailed description of the location, magnitude, and history of the geosyncline is not presented here, but it should be pointed out that this is one of the typical exogeosynclines described by Kay (1951, p. 17-20) and is not to be confused with the older concept of the "Appalachian geosyncline." Rather, this Devonian geosyncline in the eastern United States is a distinct historical unit, specifically identified as to its geographic location, orientation, and method of infilling. The magnitude of downwarping of the geosyncline is significant when considered in relation to the stable platform. In an east-west cross section of an area of almost continuous deposition, a horizontal time line 400 miles long could be shown to have been lowered 100 feet or less on the platform, 10,000 feet or more in the geosyncline.

This vast spoon-shaped mass of sediments deposited in the geosynclinal area might be generally described in terms of the sedimentary rocks at its eastern and western extremities-thousands of feet of coarse sandstone and redbeds of continental origin at its eastern edge, only a few hundred feet of marine shales, chiefly carbonaceous, at its western edge. The maze of interfingering types of sedimentary rocks, and all the possible sedimentary mixtures of both extremes, has been only partly deciphered, but it indicates downwarp, a continuously shifting shoreline, and a continuously changing depositional environment (fig. 12).

\section{IANDMASS}

The area, altitude, and mobility of the landmass to the east of the geosyncline, important as its role was, can only be inferred from indirect evidencethe sedimentary record of the geosyncline and the sparse information on scattered metamorphosed rocks in its northern component.

The geographic location of that part of the landmass considered to have been the major source of sediments during Middle and Late Devonian time can be described only generally. It was an elongated mountainous area that occupied much of the area of the present Coastal Plain, extending from central Connecticut southwest to the north-central part of North Carolina. One of the difficulties in any attempt to visualize the location and magnitude of the source area is the fact that an unknown volume of sediment was deposited east of the postulated Late Devonian landmass. The altitude, relief, and surface rocks of the landmass at any one moment during its history can only be inferred from the kind, coarseness, and apparent rapidity of deposition of the sediments laid down beyond its western margin.

An important northern component of this landmass undoubtedly existed in the northern New England States and adjacent parts of Canada, but its geological significance relative to the rest of the eastern United States is not clear. The deformation and plutonic activity that took place in this area and presumably some distance to the southwest during Middle and Late Devonian time (King, 1951, p. 100) are referred to the Acadian orogeny (Shickshockian orogeny of some authors). Upper Devonian rocks in New England and the Maritime Provinces are seemingly east of the Late Devonian source area.

\section{INTERIOR PLATFORM}

The geosyncline and the landmass were tectonically active, but the third major element was the stable interior platform-a part of which is the area of this report. The stability of this platform is indicated by its earlier Paleozoic history and, more significantly, by the extensive continuity in thickness and lithology of the Upper Devonian deposits. However, several minor flexures of varying significance were superimposed upon it (fig. 13) : (a) the oval-shaped Michigan basin, which had subsided to receive a great thickness of Silurian sediments, continued to subside, though much less, in Devonian time; (b) a small part of the Illinois basin, which subsided slightly during the latter half of the Devonian; (c) the Ozark area, an important positive area in much of Paleozoic time that apparently existed only as a broad flat area slightly above sea level during Late Devonian time; and, (d) marginal land areas on the southern and northern parts of the interior platform that also were broad flat areas only slightly above sea level. Thus the interior platform during Late Devonian time can be generally described as a stable area, with the exceptions noted above and except for a very slow widespread lowering of the platform about 100 feet relative to sea level.

The general relationships between and within the tectonic elements can be only broadly described, and the influence of these elements on sedimentation during the last half of the Devonian in the eastern United States can be only grossly defined. What knowledge does exist, however, can be utilized to advantage in " interpreting the sedimentary history of the Chattanooga shale.

\section{EXTENT OF THE CHATTANOOGA SHA}

The Chattanooga sea of this report is that Late Devonian epicontinental sea in which the Chattanooga 
shale and many similar correlative sediments were deposited in the eastern and central United States. The stages of expansion and the greatest magnitude of this sea (pl. 14) were interpreted from the known and inferred distribution of individual marine units of Late Devonian age.

Much of the interior platform had been drained of the early Middle Devonian epicontinental sea, and an interval of erosion beveled the uplifted and slightly warped rocks of a broad area. In late Middle Devonian time, marine waters again began to encroach on the interior platform, advancing from the geosynclinal area to the east, from the Ouachita area to the southwest, and perhaps from the northwest across the Dakotas and Iowa. Early in Late Devonian time a shallow sea covered much of the interior platform, then continued to transgress slowly, with one apparent slight interruption, until it reached its greatest extent near the end of the Devonian period.

The invasion of the Chattanooga sea might be likened to the spreading of water across an ordinary concrete floor, where slightly lower areas mark the routes of advance. Thus a panorama of Tennessee, Alabama, and nearby areas early in Late Devonian time would have shown a fingering and interconnecting shallow sea spread among broad flat lowlands ranging in area from a few square miles to thousands of square miles. Probably only a third of the entire area of this report was inundated at this early stage.

From early in Late Devonian until the end of the period the sea advanced with extreme slowness across the broad lowlands. The subaerial erosion of the peneplained surface had reached a stage where further reduction of that surface was negligible, and the erosive power of wave, current, and tidal action was at a minimum, by reason of the extreme shallowness of the sea in the irregularly shaped and sized pans. Though considered unlikely, the margins or even large parts of the lowlands may have been intermittently awash, but any sediments that may have been laid down on these lowlands were deposited there only temporarily and were later removed and redeposited in the sea. Evidence like that in the sequence of outcrops near Bodenham, in western Giles County, Tenn. (p. 14), suggests, however, that the strandline belt of erosive activity was narrow.

The greatest extent of the Chattanooga sea, near the end of the Devonian, can be inferred from the maximum known distribution of Devonian black shales. Later the sea spread markedly at the beginning of Mississippian time, covered the Devonian muds on the interior platform, submerged the islandlike lowlands, and spread onto additional lowlands not covered by the Chattanooga sea.

These interpretations are in accord with the evidence presented in this report and the known facts concerning Late Devonian and Early Mississippian stratigraphy beyond the limits of this study. The history of deposition of the Chattanooga and related black shales as here described differs from the concept of Grabau (1906, p. 593), which holds that the entire thickness of the black shale in a specific area represents a short-lived shoreline phase of a transgressing Late Devonian and Mississippian sea. It also differs from the theory of Rich (1951b, p. 2038; 1953 , p. 1535-1536) that a sea covered much of the eastern United States continuously during much of Silurian and presumably all of Devonian time but that the black shale accumulated only after the water became relatively deep.

\section{SEDIMENTATION SOURCES}

The sources of the detrital sediment for the Chattanooga shale in the region of this report can be conveniently divided into four major areas, based on their inferred location and general relief during Late Devonian time: the large landmass to the northeast; the lowlands bordering the Chattanooga sea to the southeast, south, and southwest; the Ozark area to the west and northwest; and the island areas in the sea. Other places at greater distances may have supplied much windblown dust. Obviously, the position of any specific outcrop of Chattanooga shale relative to the four listed areas would alter the following generalizations on the significance of each source, but the continuity of the lithology and thickness of the formation suggest that only slight modifications are necessary.

The eastern landmass supplied most of the sediments in the geosyncline. A stratigraphic section of Middle and Upper Devonian rocks from eastern West Virginia to north-central Tennessee (shown in part in pl. 12), shows that deposits are thinner and finer grained at greater distances from the center of the geosynclinal area. Of the great volume of sediment derived from that landmass, an extremely small fraction may have reached the central Tennessee area, and that must have been the finest and most buoyant, to be transported for hundreds of miles through several environments. Thus, some of the clay- and silt-sized quartz and mica in the Chattanooga shale may have originated far to the northeast.

Deep erosion of the folded southern Appalachians east and southeast of the area of this study has 
destroyed most of the Upper Devonian rocks, and little is known about the Chattanooga shale in that area. So far as it can be traced, the shale does not thicken eastward or southeastward into a coarser clastic facies; this fact is consistent with the belief that the Late Devonian and Early Mississippian were times of tectonic quiescence in the southern Appalachians (King, 1950, fig. 9, p. 661-662). It is thus assumed that a land area of low relief existed in western North Carolina and that its significance as a source of sediment was intermediate between that of the landmass to the north and the lowland areas to the south.

Farther south, in northern Alabama and in nearby parts of Mississippi and Georgia, the Chattanooga shale was deposited widely during Gassaway time. In general this shale is fine grained, and in places seems to thin to extinction. These facts suggest that the bordering land was low and simply an extension of the peneplain on which the shale was deposited. This extensive lowland, underlain chiefly by limestone, supplied some of the organic material in the Chattanooga shale and much of the clastic sediment. A sandy facies of the Chattanooga just south of the area of pl. 1, at Pratts Bluff 5 miles northeast of Centreville, Bibb County, Ala., and in the northeast corner of Mississippi and nearby parts of Tennessee, suggests the proximity of large streams entering the Chattanooga sea. Glover $(1959$, p. $156-157)$ has noted that the formation is coarser and more irregular in thickness toward the southeast, and that it pinches out near Birmingham, Ala.

The eastward extent of the Ozarkian land area during Chattanooga time is postulated on fragmentary evidence, for any Chattanooga shale that existed in the present Coastal Plain area of western Tennessee and Kentucky either has been eroded or was not reached by the drill. Freeman (1951) showed that Ozarkia was a land area preceding Chattanooga shale deposition, and the area is not known to have been inundated again until middle Mississippian time. A progressive overlap of Upper Devonian black shale and Lower Mississippian rocks onto the Ozarkian area in eastern and southeastern Missouri is known, and the same condition probably existed in western Tennessee.

A few islands apparently remained above water through all or part of Chattanooga time, and they doubtless supplied some sediment to nearby parts of the sea. The Hohenwald platform, the largest of the known islands, was probably isolated from the mainland during Gassaway time and gradually decreased in size, but by the end of Gassaway time it was probably still about 1,500 square miles in area. The shaly and silty bedrock that was exposed in the western part of the island (pl. 3) probably contributed to the clastics in the nearby part of the Chattanooga shale.

What proportion of the mineral grains in the formation may be windblown is unknown, but it seems likely that windblown dust, including volcanic ash, would account for a significant fraction (Ross, 1955). The ash that formed the Center Hill bentonite bed is an example of sediment transported by wind from a distant area.

Remains of several types of marine plants are important constituents of the black shale, and some land plants are known. The marine plants were floating forms that lived on or near the surface of the water.

The basal sandstone of the Chattanooga shale, in contrast with most of the formation, is made up largely or wholly of slightly reworked debris from nearby sources. Quite clearly the soil on the peneplain, which was underlain chiefly by limestone, was worked over by the advancing sea sufficiently that the clay and other fine material were removed. The coarser particles, including chert and quartz grains and fragments of assorted fossils, were moved only short distances. The "blue phosphate" of West Tennessee has already been mentioned as an unusual form of the basal sandstone made up largely of reworked fragments weathered from the underlying Leipers limestone which, in that region, abounds in phosphatized fossils.

The thin but widespread and coarse Bransford sandstone bed at the base of the Gassaway member is thickest in the vicinity of Nashville. Its source is unknown, but it probably was derived from some nearby area that was elevated at the end of Dowelltown time. Some of the grains may have been reworked from the Dowelltown member, but a large part of them, including fragments of Cyclora-like gastropods, must have come from the older formations. As this sandstone bed commonly lies above several feet of shale of Dowelltown age many miles from any place where the Dowelltown is known to be absent, the grains must have been transported considerable distances.

The sources of other sandstone beds that are scattered erratically through the shale, especially in the lower part at any given place, are not known. It is presumed that many of the erratic beds resulted from abnormally strong inflow of nearby sand-carrying streams. Others may be simply a local concentration of the coarser grains of the muds that had already been deposited and had then been stirred up by unusually strong storms or currents. 


\section{TRANSPORTATION}

The sediment that made up the Chattanooga shale probably was carried to their destinations by slow seabottom traction, by water suspension, and by wind.

The 200-foot thickness of finely laminated black shale in the Flynn Creek structure is believed to show that the sediment was shifted freely, though very slowly, along the sea floor, which was always well graded. This process, oft repeated during a long span of time, may have moved some of the sediment long distances, especially if only small amounts of new material were being brought to the region.

Transportation in suspension by water currents was probably an important process where fine-grained sediment was involved. By this method mud from the nearby peneplain was dispersed widely, but it is likely that some of the fine-grained mica and clay were brought long distances from other areas; some sediment may have been transported westward and southwestward from the geosynclinal area in the VirginiaWest Virginia region where it was accumulating much more rapidly; such sediment was probably the finest grained and most buoyant of the great volume that was sifted and sorted by the waters in the geosyncline.

Wind may have transported much silt great distances to the Chattanooga sea. The possibilities of this method of transportation are strikingly illustrated by the Center Hill bentonite bed, which has flakes of biotite about $1 \mathrm{~mm}$ in diameter, together with smaller particles of quartz and feldspar. Modern dust storms carry silt-size particles of quartz and other minerals hundreds and thousands of miles, and a single storm may deposit a noticeable film of dust far from its source. If the Chattanooga shale represents the sediment deposited through millions of years, it is expectable that windblown dust would constitute an appreciable part of the shale. Foerste (1901, p. 431) suggested such a method of accumulation more than 50 years ago:

The fissile black shale is composed of particles so light that they could have easily been blown by the wind. The remarkably fine grained character of the fissile shales, the entire absence of coarser material except at their base, and their remarkably wide geographical distribution suggest that they may possibly consist of windblown particles, derived perhaps from many strata, from points far distant from one another.

\section{RATE OF ACCUMULATION}

The rate of accumulation of the Chattanooga shale appears to have been so slow as to require consideration. The conodonts within the shale suggest that it was accumulating throughout most of Late Devonian time. Estimates (Marble, 1950, p. 18) of the durations of the geologic periods, based on radioactive age determinations, indicate that the Devonian period lasted about 55 million years; it seems probable that Late Devonian time lasted at least 10 million years. It may be very conservatively estimated that the Chattanooga sea covered the land during only half of that time, or 5 million years. If 35 feet of shale, the approximate maximum normal thickness in most of the area here under consideration, represents the accumulation of 5 million years, then each foot of shale represents, on the average, about 150,000 years. These figures, of course, have little quantitative value except to indicate an extremely slow rate of deposition.

According to Pettijohn (1949, p. 472) the probable rate of deposition for compacted shale is about 1 foot in 700 years. Bradley, $(1929$, p. 99) in studying the Green River formation, estimated that the moderately rich oil shale accumulated at the rate of 1 foot in 4,700 years and the richest oil shale at the rate of 1 foot in 8,200 years.

Several studies of the fine red clay in the deep parts of the ocean basins (Shepard, 1948, p. 305-309; Sverdrup and others, 1942, p. 1038-1040) suggest that that sediment, which is thought to have the slowest rate of accumulation of any modern sediment, is collecting at the rate of about 1 foot in 60,000 years. If we assume that transformation of this clay to an indurated rock comparable to the Chattanooga shale would involve a loss of volume of 60 percent, we have apparently similar rates of sedimentation for both rocks, namely 1 foot in 150,000 years. The deep-sea clay, however, differs from the Chattanooga shale in so many ways that perhaps no comparison between them is warranted, except, possibly, the inference that the Chattanooga sea received and retained hardly more sediment than today reaches the ocean depths.

If the nearby land areas were sea-level peneplains, as is believed, and if a geosynclinal trough lay between the central Tennessee area and the main land mass to the east, then it is reasonable to suppose that the Chattanooga sea received an abnormally small amount of sediment. It may be, too, there was not a continuous rain of particles to the sea floor; rather the sediment may have been brought in only on relatively rare occasions. The times when sediment was introduced may have been chiefly when the sea was somewhat more agitated than normal and could transport material in suspension or when an occasional dust storm supplied a small amount of silt. Another factor may have been insufficient subsidence of the area to make room for a greater accumulation of mud. In the one known place where more mud did accumulate, the Flynn Creek cryptoexplosive area, there is evidence of an abnormal amount of subsidence. 
Some support for the theory that the sea bottom may have received no sediment during extended periods of time is the presence of scattered small phosphate grains, which have been noted in thin sections of the shale, and of larger phosphate nodules in the upper part of the shale. Goldman (1922) summarized evidence and opinions that phosphate nodules form on the sea floor so slowly that their presence indicates that no clastic sediment was deposited for a considerable period of time.

The possibility that the laminae in the Chattanooga shale are varves (annual pairs of layers) has been seriously considered. Bradley (1929) and Rubey (1930) described apparent varves in the finely laminated Eocene and Upper Cretaceous shales of Wyoming and nearby areas. Both writers called attention to the alternation of laminae that are dominantly of mineral matter with those of organic matter; they mentioned the persistence of these layers as evidence of their accumulation in quiet water, presumably below wave base. Both men used the varves as a basis for calculating the rate of accumulation of those beds and obtained results that are in general agreement with estimates of the duration of those intervals of time based on radioactivity. The average thickness of the varves of both areas is about $0.2 \mathrm{~mm}$.

We concluded that the laminae in the Chattanooga shale are not varves. In the first place, the mineralrich layers are so variable and discontinuous (pls. $9 D$, $11 B$ ) as to suggest that the sediment was disturbed and rearranged many times after it reached the sea bottom and that conditions for the preservation of fine annual layers did not exist in the Chattanooga sea. Furthermore there is no indication of a consistent gradation from one type of lamina to the other, as is usual in the case of varved sediment. More likely the laminae are those that were accidentally preserved at irregular intervals on a sea whose bottom sediment was subjected to occasional agitation. The silt layers may also represent, in part, infrequent times when a measurable amount of silt reached the sea, either by an incursion of muddy water or by an occasional dust storm.

In the second place, the thickness of the laminae are altogether incompatible with a reasonable estimate of the time required for the sediment to accumulate. As can be seen from plate 11, the average thickness of a pair of layers that might reasonably be considered a varve is about $1 \mathrm{~mm}$. At that rate, 1 foot of Chattanooga shale would represent only about 300 years, and the entire 15 feet of the Gassaway member would represent about 4,500 years. More likely, however, the Gassaway member required several hundred times as long as this to accumulate. Any estimate of the duration of Chattanooga time from calculations based on supposed varves is so far out of harmony with the evidence, largely paleontologic, that the Chattanooga represents most of Late Devonian time, that we do not believe the layers are varves. We conclude that the laminae are largely accidental and do not represent uniform periods of time.

\section{COMPACTION}

The Flynn Creek cryptoexplosive area affords an unusual opportunity to determine the amount of compaction the shale has undergone since the end of Chattanooga time. As already stated (p. 10), the shale in this basin is as much as 200 feet thick, and the overlying Maury formation and Fort Payne chert sag about 100 feet over the thickest part (fig. 3). As also pointed out, it is highly probable that this subsiding area was continuously filled with the accumulating mud. The shale within this small basin differs in no apparent respect from that of the surrounding area except in being as much as 10 times as thick. Virtually all the extra thickness is in the Dowelltown member.

The subsidence of the floor seems to have taken place during Dowelltown time, and probably no further significant settling occurred during Gassaway time. Most of the early compaction of the Dowelltown beds also took place during Dowelltown time, and the weight of the overlying Gassaway sediment, now about 15 feet thick, was insufficient to cause much additional compaction. Later burial, however, by probably 2,000 feet or more of beds of Mississippian and Pennsylvanian age, compressed the 300 feet of Chattanooga shale only about an additional 100 feet to its present thickness of about 200 feet (disregarding the compaction of the present 20 feet of shale in nearby areas, which is assumed to have been comparable and relatively negligible).

A detailed study of the shale and the associated rocks in this small and unusual structural and depositional basin might provide much interesting information on sedimentation and compaction in this type of shale. The evidence cited seems to indicate that the Chattanooga shale was reduced in thickness by about one-third as the result of post-Chattanooga loading.

\section{RELATION OF BLACK SHALE TO GRAY CLAYSTONE}

The reason for the alternation of black and gray beds in the Chattanooga shale is not known and not easy to conjecture. In the upper unit of the Dowelltown member the gray claystone is the dominant rock 
type, but in the middle unit of the Gassaway member it is a minor constituent (fig. 5). In both units the individual gray beds seem to extend over large areas. The change in conditions from one favoring the formation of black shale to one favoring gray claystone was probably not periodic, because some black beds in these units are hardly more than paper-thick and others are as much as half a foot thick. The gray beds have a simlar range in thickness.

Any explanation of the alternation of the two types of beds must take account of the following characteristics of the gray claystone: (a) It appears to represent either oxidizing conditions or less intense reducing conditions than characterize the rest of the formation; (b) the grain size of the claystone is somewhat smaller and clay minerals are more abundant than in the black shale; (c) it is poorly laminated, in contrast with the black shale; (d) it contains fewer fossils than does the black shale; (e) its contacts with the beds of black shale are commonly slightly gradational, though some are fairly abrupt; (f) in the Dowelltown member it disappears northward from the vicinity of Cannon County, where it is thickest, by change in facies; (g) conditions favorable for its formation were apparently widespread over several hundred square miles at any given time.

Although the conditions that caused the change from black mud deposition to gray are not known, it is conceivable that a colder climate may have caused increased vertical circulation of the water, or periods of increased rainfall may, from time to time, have increased the flow of sediment to the sea. Numerous other suggestions could be offered to explain the alternations of black and gray beds, but all would be mere speculations grounded on little or no evidence.

\section{ENVIRONMENT OF DEPOSITION}

GENERAL CONSIDERATIONS

Just as geologists have long differed over the age of the black shale, so they have differed in their ideas on the environment in which the Chattanooga and other black shales have accumulated. Some workers have thought that the shales originated in stagnant basins hundreds or even thousands of feet deep, while others have maintained that the shales originated in shallow water or even on vast mud flats. Some have thought the shales accumulated as widespread sheets laid down simultaneously over wide areas, while others have thought they represented the near-shore facies of an advancing sea. Many types of evidence have been used in support of these opposing views, but, as in the controversy over the age, it has been difficult for any school to find evidence sufficiently convincing to silence the opposition.

The Chattanooga shale is clearly a marine deposit, as indicated by the presence of glauconite and phosphate and of linguloid brachiopods, abundant conodonts, and a few other marine fossils. Most writers agree that such mud accumulates in quiet or tranquil water that is low in oxygen. In such an environment sulfur it liberated by decomposing organic matter and poisons the water with hydrogen sulfide, some of which unites with available iron to form pyrite or marcasite in the bottom muds; the usual bottom scavengers are absent and only anaerobic bacteria can live. Organic matter that sinks from above or drifts in from other areas makes the water sulfurous and generally foul. The acidic water inhibits the precipitation of carbonates and dissolves any calcareous shells that enter it. Mud and other sediment normally accumulate slowly in this environment and imprison large quantities of undecomposed plant remains and such phosphatic objects as bones, teeth, conodont parts, and shells of linguloid brachiopods. On this much there is agreement.

For comparison, some writers have pointed to the known present-day accumulation of black mud in the depths of the Black Sea, while others have pointed to black muds that are accumulating in shallow parts of the Norwegian fjords, Baltic Sea, Chesapeake Bay, and other bodies of water. Some have argued that the great extent and widespread uniformity of the Chattanooga and related black shales, together with the general absence of ripple marks, cross-bedding, mud cracks, and scour channels, indicate their deposition in deep seas. Others have called attention to places where the shale is intimately associated with crossbedded and ripple-marked sandstones that are clearly of shallow-water origin. Some have thought that the paper-thin laminations of the shale indicate quiet and deep water, but others have thought the laminations indicate repeated agitation in shallow water. Some have thought that the sulfurous bottom water requires a body of relatively deep and quiet water to permit a density stratification, whereby stagnant bottom waters are rarely aerated by admixture of water from the upper layers; others have suggested that stagnant and sulfurous water can and does exist in shallow areas where abundant algal growth or absence of tides, currents, and waves leaves the water undisturbed. Writers have been concerned, in part, with different formations, which may have been laid down under somewhat different conditions, but many have expressed conflicting opinions regarding 
the same rocks and have even used the same evidence to support opposite views.

In most of the published discussions regarding depth of water, little or no attempt has been made to define the terms "deep" and "shallow." Unfortunately, these relative terms have quite different meanings to different people, for example, to oceanographers and to harbor engineers. For a long time oceanographers commonly considered 100 fathoms (600 feet) to be the approximate division line between shallow and deep, and it seems probable that most geologists have been in general agreement with that usage. The depth of 100 fathoms was apparently chosen because that was long thought to be the approximate lower limit to which water is agitated by the largest surface waves and because it was also thought to be the approximate depth at the outer limit of the continental shelves. However, submarine photographs show clear evidence of currents strong enough to move sand at depths of a few thousand feet. On the other hand, Dietz and Menard (1951) presented evidence that the orthodox concept of a 100-fathom wave base is faulty and that little significant wave abrasion takes place below the "depth of vigorous abrasion" (p. 2011), which they find is commonly at 5 fathoms or less.

Other factors that may be fully as important as depth in the control of type of sedimentation include salinity, $\mathrm{pH}$ value, oxygen content, temperature, density stratification, currents, wave agitation, turbidity, and organic content, as well as the types of sediments brought to the area by rivers, currents, winds, and floating objects.

A primary requirement for the accumulation of these plant-rich muds appears to be stagnation, which results when horizontal or vertical circulation is insufficient to take oxygenated water to the bottom. Stagnant conditions have been reported to exist at various depths ranging from several thousand feet in the Black Sea to a few tens of feet in some of the Norwegian fjords (Strom, 1948) and even only a few feet in the Baltic Sea (Twenhofel, 1915), Barnegat Bay, New Jersey (Lucke, 1935), and Chesapeake Bay (Goldman, 1924). The depths required for stagnation in a sea as widespread as the Chattanooga sea are unknown because no comparable sea exists today.

Obviously it is difficult to select criteria that indicate satisfactorily the environment in which the widespread Chattanooga shale originated. It was necessary, therefore, to consider the significance of many characteristics of the formation, to explore new lines of reasoning, to consider the implications of various assumed origins, and to draw independent conclusions. That procedure was followed in the present investiga- tion by several workers, some of whom were only slightly acquainted at the time with the abundant writings on the black shale, and all came to the same conclusion-that the Chattanooga shale of the central Tennessee area accumulated in relatively shallow water at depths of tens of feet rather than hundreds. It seems appropriate, however, before elaborating on that conclusion, to cite some of the views that have been expressed concerning the environment of deposition of the mud.

\section{PREVIOUS VIEWS}

The belief that black shales originated in relatively deep water was expressed by Lapworth $(1889$, p. 60$)$, Clarke (1885, p. 14; 1904, p. 199-201), Schuchert (1910, p. 446; 1915), Marr (1925), Ruedemann (1934, p. 51) and Rich $(1948 ; 1951 a$, p. 13).

Studies by Androssow (1897) of the hydrology of the Black Sea, where black mud is accumulating in water that is mostly 4,800 to 7,200 feet deep, have apparently led many geologists to believe that most black shales originated in similar isolated deep basins. The assumption of such an isolated deep basin affords an easy means of explaining a density stratification of the water, the lower part of which would be unaerated and would quickly become sulfurous from accumulating organic matter.

Clarke (1904, p. 200) thought the Devonian black shales of New York State represent deposits in an "inclosed marine body $* * *$ of great depth and imperfect vertical circulation."

Schuchert (1910, p. 446) thought that the black shales represent deposits in closed or stagnant arms of the sea as in the Black Sea.

Ruedemann (1934, p. 43-52) summarized many of the opinions on the conditions of black shale deposition, and concluded (p. 51) :

It can be stated as a general proposition that Lapworth's theory of the origin of graptolite shales as a special facies representing deposits in a quiet zone of deeper water is still the theory best supported by the facts, and it may be added that, for reasons given above, the same is true of most finegrained black shales.

* * * This does not mean the abyssal depths but only the deeper littoral zones.

Rich (1948) stated that the Chattanooga and related black shales of eastern North America probably accumulated "in relatively deep water-at least below wave base" and suggested that the black shales were deposited "in poorly aerated water in what was then the deepest part of the Appalachian geosyncline." Later $(1951 \mathrm{~b})$ he elaborated on this idea and cited the Chattanooga and related black shales of eastern United States as examples of sediments that had ac- 
cumulated in deep water-his fondo environment. $\mathrm{He}$ calculated that the sea was between 300 and 700 feet deep.

Other writers, however, have thought that black shales do not require deep water but that special conditions in shallow water would suffice. Ulrich (1911, p. 358) suggested that the black graptolite shales of the Paleozoic were deposited in troughs connecting large bodies of open water or in broad shallow basins and that enclosed areas or stagnant conditions are not necessary. He thought (p. 357) that the black shales of the eastern United States were formed in shallow water because the deposits are widely distributed, the fauna is chiefly pelagic marine and requires currents for its wide distribution, and the beds overlap to extinction on the flanks of certain areas of uplift.

Twenhofel (1915) described a place in the Baltic Sea where black mud is accumulating in water so shallow that small boats are propelled by poles.

Grabau and O'Connell (1917) concluded that the graptolitic shales of southern Sweden were deposited in comparatively shallow water and that similar shales in southern Scotland were deposited in lagoons and on the flood plain of a large delta. They also cited the Bay of Danzig on the south coast of the Baltic Sea where the Vistula River, after draining the comparatively flat country of Poland and southeast Prussia, deposits a dense black mud having a large quantity of organic matter.

Goldman (1924) described black muds that are accumulating in Chesapeake Bay in deep holes, in deeper parts of the tributary river bottoms, and near the shore between the sandy shore deposits and the more scoured central channels.

Moore (1929, p. 465) suggested that the thin but persistent beds of black fissile shale in rocks of Pennsylvanian age indicate deposition in

extremely shallow water, with sunlight promoting plant growth and aiding in partial decay, and with too little depth for circulation and effective wave or tidal agitation.

He expressed the belief that the widespread Pennsylvanian seas of the midcontinent were probably not more than 200 feet deep.

Morse $(1930$, p. 60) in describing an impure facies of the Chattanooga shale, for which he proposed the term "Whetsone Branch shale," (p. 18 and 42) wrote:

In some of the intervals both shales and sandstones are concretionary, crossbedded, and contorted, and some of the sandstones are ripple-marked. At one or more vertical positions contacts of two intervals resemble contemporaneous erosion or unconformable surfaces. All these differences in texture, structure, and the like are records of the repeated changes in shallow water conditions of deposition.

Hard (1931), in describing the black shale of the Genesee group of Late Devonian age in New York, noted that it is so closely related to shallow water sediments that it, too, must have been deposited in relatively shallow water. He also stated (p. 177) :

Most of the theories about bituminous shale environment require tranquil water to account for the "paper thin" bedding of the shales. This desired tranquillity is generally explained by supposing that deposition occurred in either very deep or very shallow water or in partly protected basins. However, when the fact is disregarded that the beds may have been compressed to one-fifth or less of their original thickness, it is quite possible that any moderate agitation would not be permanently reflected in shales, for the colloidal character and fineness of the material would cause it to remain in suspension during periods of disturbance until the water again became tranquil. When this material was redeposited, of course, some differential settling occurred. This explains the repetition of thin layers of fine quartz grains in these shales. If scour channels are retained they are extremely difficult to observe, for it is almost impossible to trace individual lamination for any distance.

Twenhofel (1932, p. 10), in referring to previous theories on black shales, stated that he did

not consider the deep water environment, first advanced by Lapworth and subsequently supported by Clarke, Marr, Ruedemann, and others, as tenable in the least degree. Too many Black Seas are required and, furthermore, the muds of the Black Sea would not be particularly black after drying as they owe their blackness to black monosulphide and disulphide of iron, and they lose color when dried.

Lucke (1935) called attention to local accumulation of black mud in Barnegat Bay, New Jersey, in water only a few feet deep.

Stockdale (1939, p. 38) wrote concerning the Chattanooga shale of Kentucky and Tennessee:

Evidence strongly points to its being a shore or near-shore facies formed on the south shore of the Late Devonian-Early Mississippian sea which advanced southward upon a very low, nearly flat land surface.

Later Moore (1949, p. 32) stated concerning the black platy shales, which are high in carbonaceous and radioactive content and are unfossiliferous except for such noncalcareous types as conodonts, ostracodes, and phosphatic-shelled brachiopods, that they $" * * *$ cannot be interpreted reasonably as a record of the euxinic conditions of an unoxygenated sea bottom." Instead, he thought that " $* * *$ such shale may be a deposit of very shallow marine waters so clogged by abundant growth of sea weeds that agitation of the bottom by waves and currents was virtually nil."

The foregoing citations are samples of the opinions that have been expressed concerning the origin of black shales, and of the reasoning used in the argu- 
ments for deep and shallow water. The thin bedding and high organic content have been used to support both hypotheses.

A summary of a number of published explanations relative to the origin of black shale and of the factors that must be considered was given by Twenhofel (1939). Later Trask (1951) presented a review of the depositional environment of black shale at a synposium on the paleoecology of shale and evaporite deposition held by the American Association of Petroleum Geologists. Trask's abstract is here set forth in its entirety because it has not been previously printed in a readily available form; his style is preserved:

\section{Depositional environment of black shale}

Black shale is characterized by :

1. Shaly structure, commonly fissile or thin-bedded,

2. Very fine-grained size of constituent particles,

3. High organic content,

4. Black or dark color,

5. Uniform character throughout considerable areal and vertical extent,

6. Absence, scarcity, or dwarf nature of fauna,

7. Low content of calcium carbonate, relatively high content of iron sulphide and varying quantities of phosphate and iron carbonate.

To account for these features the following inferences could be considered :

1. Deposition in a basin, marine or brackish, in which subsurface water is stagnant and is in a state of reduction,

2. Long continued density stratification of water in basin,

3. Orogenic quiet for material length of time,

4. Narrow seaward outlet of basin,

5. Shallow sill at outlet, or basin located in warm-temperature or warm climate,

6. Intermediate depth of basin, but depth probably is not critical,

7. Adequate replenishment of surface water to support abundant life,

8. Warm-temperature and humid or semi-humid climate,

9. Relatively rapid rate of supply of terrigenous constituents,

10. High initial water content of sediments with resulting compaction of order of 90 per cent,

11. Low relief of land adjacent to sea.

The stratigraphic relationships of black shale suggest deposition :

1. On the seaward rather than on the Iandward side of geosynclinal basins,

2. At a time materially in advance of final orogenic destruction of the geosyncline.

J. M. Schopf believes (oral communication) that the mud from which the black shale was derived could hardly have been black, but must have been brown, because of the abundant microscopic plant particles. As the plant matter altered under reducing conditions the rocks became black in much the same manner that brown peat changes to black lignite. For simplicity, however, and to avoid confusion, the unconsolidated sediments are referred to throughout this report as black muds.

\section{INDICATIONS OF DEEP-WATER ORIGIN OF THE SHALE}

In our studies of the Chattanooga shale in Tennessee and nearby areas, we were impressed by a combination of circumstances that point strongly toward a shallow-water origin. But before presenting arguments for that belief, it seems wise to comment on four characteristics that, at first thought, suggest deep water. These are the remarkably uniform fine-grained character of the sedimentary rocks, the apparent absence of ripple-marks and scour channels, the preservation of carbonaceous plant material (which implies stagnant and tranquil water) and the presence of phosphatic nodules and lag-concentrates. Each of these is considered in the following paragraphs.

The remarkably uniform fine-grained character of the sedimentary rocks.-If the only source area for sediment in the Chattanooga sea were an extensive peneplain more perfect than any that exists today, if that peneplain were formed largely on limestone and covered by a mantle of soil and vegetation, and if it were drained by small or sluggish streams, then only fine sediment could be expected to reach the Chattanooga sea. The thin layers of coarse and fine silt that make up the black shale, which are microscopic in thickness and which are often interpreted as indicating deep water, are probably beitter explained by assuming that the bottom waters were subject to gentle but frequent agitation. This agitation may have been insufficient to aerate the bottom water, yet sufficient to shift the mud particles slightly, transport them short distances, and sort them into minute laminae.

A notable characteristic of the shale is the lack of continuity of individual laminae. Microscopic study of the dense black shale shows that laminae of quartz silt pinch and swell and even disappear within the limits of a thin section. Attempts to correlate most of the siltstone laminae from outcrop to outcrop have been unsuccessful. Seemingly, if this sediment had accumulated in deep and quiet water the silt layers would be much more persistent.

The apparent absence of ripple-marks and scour channels.-The absence of ripple-marks in most of the material appears to result from the fact that the muds were too fine grained to have retained ripple structures, even if such structures ever existed. In reality, however, the thin sandstone beds that are present locally in the shale do show small ripple-marks at many places. Even scour channels, cutting a foot or 
more into the underlying shale, have been observed at a few places. These are in different parts of the formation and, had a special search been made for them, many more would doubtless have been found. Two examples of such scour channels are locality 101, near Woodbury, and locality 107, near Manchester. Obviously the absence of ripple-marks and scour channels cannot be used as an argument that the shale formed in deep water.

The preservation of carbonaceous material, which implies stagnant and tranquil water.-The mud must have accumulated in water that was stagnant, unoxygenated, and reasonably quiet, but it is unnecessary to assume that the water had to be deep. Pepper and deWitt (1950) showed that Upper Devonian black shales of New York are interbedded with shallowwater sandstones and shales. Stagnant conditions could be explained by assuming that a shallow area of deposition was partly separated from other areas by submarine bars that inhibited circulation and caused a stratification of the water, as in modern fjords. However, the differences in size and other characteristics between fjords and the sprawling Chattanooga sea are so great that any such analogies are not entirely warranted. Actually, a sea as extensive as the Chattanooga and as far removed from the open ocean (pl. 14) might well have been stagnant without having been barred. Moore's suggestion $(1949$, p. 32) that an abundant growth of sea weeds could have choked a shallow sea and caused stagnation is much more appealing to us than the assumption of a barred basin, either deep or shallow. In such a sea, ample carbonaceous matter is also available for accumulation on the bottom.

Keulegan and Krumbein (1949) showed by mathematical analysis that a gently sloping sea bottom, if sufficiently widespread, will cause incoming waves to lose their force so gradually that at no place do they break or otherwise produce sufficient motion of the water to stir up the bottom muds violently. The Chattanooga sea was so widespread, and the submerged peneplained surface was so smooth, that the conditions postulated by Keulegan and Krumbein may well have prevailed. If any part of the sea was deep enough and sufficiently extensive to permit large waves to form, the waves may well have lost their force by the time they reached the area where the black muds might be disturbed.

The presence of phosphatic nodules and lag-concentrates.-Phosphorite is known to be accumulating on the sea bottom in various places where normal detrital sedimentation is not taking place (for example, Dietz and others, 1942) and where the water is several hun- dred to several thousand feet deep. This fact has been used by Rich (1951b, p. 2025-2027) in support of his thesis that black shales like the Chattanooga have formed in the relatively deep water of his fondo environment. It appears, however, that much remains to be learned regarding the conditions that permit the accumulation of phosphate in sedimentary rocks. The mere fact that phosphate deposition can be recognized today only in deep water seems to us an insufficient reason to suppose that all phosphate in the past has accumulated under similar conditions. Rich (p. 2033) made a special point that the basal sandstone of much of the Devonian black shale sequence is a lag-concentrate. At many places in the Tennessee area, however, the basal sandstone contains phosphatized fragments and other material that can be identified as having been derived from the immediately underlying rocks. Other constituents of the sandstone, such as fragments of conodonts, bones, and plants, were presumably washed or floated in and added to the local residual material. It seems clear that the basal sandstone, for the most part, is made up of locally derived material such as would be expected near the edge of an encroaching sea.

\section{INDICATIONS OF SHALLOW-WATER ORIGIN OF THE SHALE}

In contrast with the foregoing characteristics, which might suggest a deep-water origin of the shale, several circumstances are collectively seen to require a shallowwater origin. These are: (a) The Chattanooga shale, or its thin basal sandstone, lies directly on the unconformity; (b) the shale contains sedimentary features indicative of a shallow-water origin; (c) the black shale beds overlap to extinction, so that most parts of the formation lie on the pre-Chattanooga rocks; (d) the black shale does not grade upward into shallowwater sedimentary rocks; (e) since Precambrian time most of the area in which the Chattanooga shale is present has been one of shallow-water sedimentation; (f) the succeeding Mississippian sea, generally considered shallow, was more widespread and thus presumably deeper than the Chattanooga sea; (g) linguloid brachiopods are common in the black shale. Each of these circumstances is discussed in the following paragraphs.

The Chattanooga shale, or its basal sandstone, lies directly on the unconformity.-Attention has been called to facts indicative of a near-shore shallow-water origin of the basal sandstone. Of especial significance is the presence of black shale within or even beneath the basal sandstone, suggesting that accumulation of some of the shale also began soon after submergence. 
As the sea spread slowly over the low land, some of this sediment must have accumulated in water only a few feet deep, for nowhere is there evidence that the surface slopes were other than extremely gentle.

If it is to be argued that the mud did not accumulate until the water was deep, whatever is meant by "deep," the absence of sediment that normally would have accumulated before the water was deep must be explained. If the sea had been there long before the black mud started forming, as suggested by Rich (1951b, p. 2035), there should seemingly be a basal concentration of bones, shells, spores, wood, conodonts, and other insoluble parts of organisms which lived in the sea or drifted into it, and which were not derived from the underlying rocks. It is even more difficult to believe that all the detritus brought into a shallow sea was swept along the bottom so completely out of the region that no local patches of the sweepings were left. It is also most unlikely that the first deposition in deep water would then have been the thin bed of sandstone, which is so intimately associated with the black shale and which is made up largely of particles derived from the underlying rocks.

Only the Hardin sandstone member and the impure phosphate shale, both restricted chiefly to the southwestern part of the area studied, could possibly be interpreted as concentrations of widespread sweepings. It is entirely unreasonable to assume that the detritus from the large area of these studies was transported to these relatively small areas or still greater distances northeastward to regions of more abundant sedimentation. The phosphatic shale, moreover, is apparently composed chiefly of materials of local origin. Furthermore, if these local facies were concentrations from a wide area, it is likely that they would have accumulated in the deeper parts of the sea and would later have been covered by a thick deposit of mud. Instead, the area of the Hardin sandstone member and the phosphatic shale has less of the typical black shale than does central Tennessee-a condition suggestive of shallower rather than of deeper water.

The shale contains sedimentary features indicative of a shallow-water origin.-The perfection of lamination and high degree of sorting suggest that the muds were agitated repeatedly but gently. The individual laminae have such sharp upper and lower boundaries that simple gravitational settling of muddy water could hardly have produced them, whereas constant reworking and winnowing could do so. Lenses of silttone or sandstone, ranging from those that do not extend across a thin section to others several feet long and a few inches thick (for example loc. 108), are also hardly expectable under conditions of simple $553638-61-6$ gravitational settling in deep water. In the Flynn Creek cryptoexplosive region the abnormally thick accumulation of black shale seems to indicate, as already mentioned, that the muds were constantly being shifted along the sea floor so that they filled any low places. In a few places scour channels a few feet wide have been seen in the shale, suggesting local currents strong enough to remove a few inches of the soft mud. In one small area where the Center Hill bentonite bed is absent, gentle marine planation seems to have removed some of the uppermost beds of the Dowelltown member. All these evidences of bottom agitation are perfectly compatible with a shallowwater hypothesis, but some of them fit into a deepwater hypothesis with difficulty.

Pepper and deWitt (1950) showed that similar Upper Devonian black shales in New York state are interbedded wtih shallow-water sandstones, and the same appears to be true in the Tennessee area on a smaller scale, notably in and near Hardin and Wayne Counties, where the shale is interbedded with poorly sorted crossbedded phosphatic sandstone that appears to be of shallow-water origin.

Because the successively higher beds of black shate overlap the lower ones, most of the shale succession lie on the pre-Chattanooga rocks. - The lowest beds at the various outcrops range in age from early Late Devonian to the very latest Devonian, depending on the apparent time of submergence. The almost complete absence of other types of sedimentary rocks of Chattanooga age below the black shale suggests strongly that almost everywhere, regardless of the time of inundation, black mud started accumulating almost immediately. Had sufficient time elapsed between submergence and the first black mud deposition for the sea to become "deep," it would be surprising indeed that no "shallow" water beds are present. In the almost universal absence of any other sediment between the black shale and the basal unconformity, we are impressed with the evidence that, as the sea crept slowly landward, black mud was the first sediment that accumulated.

The black shale does not grade upward into shallowwater sedimentary rocks. - If the black shale accumulated in deep water, it would expectably grade upward into a succession of shallow-water sedimentary rocks, but no obvious succession of this sort has been found in the Central Tennessee area. If, indeed, the top of the shale is bounded in many places by an obscure unconformity, as believed by Hass (1956, p. 23), then the proponents of a deep-water origin must explain either why no shallow-water sediment accumulated while the sea was shoaling or how it was all removed 
so completely while most of the black shale was left with a smooth upper surface.

Since Precambrian time, most of the area in which the Chattanooga shale is present has been one of shallow-water sedimentation.-Throughout the central Tennessee area, the Paleozoic sequence consists chiefly of fossiliferous limestones and shales and coal-bearing sandstones and shales. It is generally accepted among geologists that the widespread limestone deposits of the eastern interior of the United States accumulated in relatively shallow seas in which many forms of life flourished. Many of those limestones are present in the Nashville arch area of central Tennessee. That arch has been an intermittently rising area at least since early Paleozoic time, as indicated by the thinning or absence of several of the Paleozoic formations over it (Wilson, 1949 , p. 327-332), and even to the present time, as indicated by more recent uplifts. It is unlikely that during Chattanooga time, and that time only, the area reversed its tendency to rise and sank enough to be deeply submerged. It is still more unlikely that deep water covered the region as a result of a world-wide sudden rise of sea level.

The succeeding Mississippian sea, generally considered shallow, was more widespread and presumably deeper than the Chattanooga sea.-The limestones and related rocks of Mississippian age cover a larger area in southeastern United States than does the Chattanooga shale. This suggests a widespread flooding that would have caused the water in the black shale area to be somewhat deeper than during Chattanooga time. Yet the Mississippian limestone and chert deposits are generally considered to have formed in an epicontinental sea that was shallow, clear, and teeming with life. Possibly, however, the most significant difference between the Chattanooga sea and the Early Mississippian sea was the degree of connection with the open oceandistinctly limited and perhaps distant during Chattanooga time but much less restricted during Mississippian time.

Linguloid brachiopods are common in the black shale.-Many people have suggested to us that the presence of numerous Lingula in the shale is a strong indication of shallow-water origin. In this connection, Cooper (1957, p. 265) stated $6 * * *$ in modern seas all known species of the brachiopod Lingula are restricted to shallow waters, usually shore zones subject to tidal action. The genus to date has not been taken from waters deeper than 23 fathoms." He cites evidence (p. 260) that some of the Devonian Lingula must have lived in a brackish near-shore environment and concluded (p. 261) ${ }^{6 * * *}$ insofar as the Middle Devonian of eastern United States is concerned, paleogeographic and faunal evidence indicates a shallow-water and near-shore environment." Some geologists (oral communications) have expressed a reluctance to project present-day ecological conditions so far into the past, but we are impressed by the arguments of Cooper and believe that the Lingula offer strong evidence of a shallow-water origin of the Chattanooga shale.

Each of the foregoing circumstances suggests that the mud accumulated in shallow water; combined they appear to offer compelling evidence that the water was shallow. By contrast, several of these circumstances will not fit into a deep-water hypothesis. The assumption of deep water involves such serious difficulties in explaining the known facts that far more problems are created than are solved.

Although we know of no way of calculating the depth of water at an appreciable distance from shore, we believe it was only a few tens of feet, quite likely less than 100 feet. We believe that, in some places near the shore, accumulation of the mud must have begun when the water was only a few feet deep.

\section{MAURY FORMATION}

The Chattanooga shale is overlain abruptly by a unit of unusual appearance, commonly only 1 to 4 feet thick, that has been variously considered a part of the Chattanooga shale, a part of the next overlying formation, or a separate formation. Its typical green color, its lower resistance to weathering, and its distinct lithologic character all set it apart from the adjacent strata (pl. 13B,C). Hass (1956) considered this unit to be for the most part of Early Mississippian (Kinderhook) age.

In spite of its thinness, it seems best to treat the Maury as a separate formation for several reasons. In the first place, it is distinctly different lithologically from the underlying and overlying strata. Secondly, it is clearly not a part of the Chattanooga shale, from which it is probably separated, at least locally, by an obscure hiatus. Thirdly, it cannot properly be considered a basal member of the Ridgetop shale, as classed by the Geological Survey (Wilmarth, 1938, p. 13221323 ), prior to these investigations, because it is equally a basal unit of the Fort Payne chert or of the New Providence shale. Finally, its distribution is different from any of the adjacent underlying or overlying formations. Bassler (1932, p. 143) described its relation by stating "[It is] present in many places irrespective of the age of the rocks following it, so that it doubtless represents the introductory stage of the succeeding formation no matter what that may be." We would, 
however, change his word "age" to "lithologic character."

\section{HISTORY OF THE NAME}

The name Maury was first applied to this distinctive bed by Safford and Killebrew (1900, p. 141) who wrote:

Resting upon the Black shale is a bed of green or greenish shale from a few inches to four or five feet in thickness. The bed is well developed in Maury County and hence the name above given to it.

Safford and Killebrew apparently intended that the Maury be treated as a formation, as did Stockdale (1939, p. 49-51). Several writers, however, have considered it a part of the Chattanooga shale (Hayes, 1892, 1894a, b, c, d, 1895; Hayes and Ulrich, 1903, p. 2; Galloway, 1919, p. 55; Jewell, 1931, p. 37-41; Born and Burwell, 1939, p. 48). Others have considered it, at least in part, a basal member of the next overlying beds (Bassler, 1932, p. 143-144; Miser, 1921, p. 24; Swartz, 1924). Campbell (1946, p. 885, 890, 895-900) subdivided the beds that have commonly been termed Maury into smaller discontinuous units to which he applied the terms Eulie, Westmoreland, Maury and New Providence. Campbell's subdivisions are not recognized in this report, in the belief that present knowledge of the distribution and relations of the units is inadequate to warrant the naming of such thin and sporadic units.

\section{SUGGESTED STANDARD IOCAIITY}

As no definite type locality was designated by Safford and Killebrew, a suitable standard outcrop of the Maury formation was searched for in Maury County, Tenn. But good outcrops of the Maury formation in that county are scarce, and none was found that is both well exposed and reasonably typical of the formation. Consequently, an exposure in southeastern Williamson County (loc. 185), only about 5 miles from the northeast corner of Maury County, was selected as a standard section for the Maury formation. The exposure is in a steep stream gully about 50 feet south of a secondary road, 3 miles east of Bethesda and 1.2 miles east of Cross Key, near the top of the west slope of Pull Tight Hill. This locality is about a quarter of a mile east of the east edge of the Bethesda topographic quadrangle but is included on an extension of the 1949 edition of that map. The Maury formation is here well exposed in sharp contact with the underlying Chattanooga shale and the overlying Fort Payne chert (pl. $16 \mathrm{~A}$, fig. 14). The geologic section as measured at this outcrop is given below. The conodont determinations are by Hass.
Standard section of the Maury formation near Cross Key, Williamson County, Tenn.

Fort Payne chert F'eet

Limestone, cherty, fossiliferous; basal contact undulating. To top of hill, about _._._. 50

Maury formation:

Siltstone and claystone, grayish-yellow, green to greenish-gray, glauconitic; near top a thin unit has a distinctive blue-green color; lower 0.3 foot is dark gray to greenish black. Phosphatic nodules several inches in length are scattered throughout but are more abundant in a bed of variable thickness 0.3 to 0.9 foot above base; smaller nodules, of about 1 inch, are common in upper 0.1 foot. The dark-gray claystone at the base can be readily distinguished from the Chattanooga shale by the ease with which weathers and breaks out

Chattanooga shale:

Gassaway member :

Shale, black, tough ; phosphatic nodules scattered throughout. Following conodonts found: Hindeodella sp. A and Spathognathodus aculeatus in upper 1 foot; Spathognathodus inornatus in lower half foot

Shale, black, tough. Palmatolepis glabra, $P$. perlobata at 0.8 to $0.9 \mathrm{ft}$. below top of interval_ Siltstone or claystone, dark-gray; conodonts abundant, including the two above and the following diagnostic ones: Ancyrognathus bifurcata, Palmatodella delicatula, Palmatolepis gracilis, $P$. quadrantinodosa, $P$. subperlobata $\quad \cdot 0.1$

Shale, black, tough _-_

Total Gassaway member -_-_-_-_-_-_-_-- 5.4

Dowelltown member:

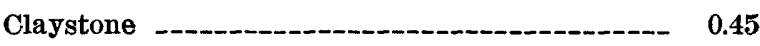

Center Hill bentonite bed _._._._._._. 0.05

Claystone _..._-_._._-_._- 0.2

Sandstone _-_._.

Claystone, having thin interbeds of black shale. Contains following diagnostic conodonts: $A n$ cyrodella sp. fragments, Ancyrognathus euglypheus, A. sp. fragments, Palmatolepis subrecta, $P$. unicornis, $P$. sp. fragments _-

Shale, black, tough _._-____- $\mathbf{7 . 0}$

Covered _-_._-_____ 1.0

Total Dowelltown member exposed _-_-_-_--- 13.2 Total Chattanooga shale exposed _......... 18.6

Limestone.

\section{GENERAI DESCRIPTION}

The Maury formation consists chiefly of various proportions of greenish claystone, siltstone, shale, and glauconitic sandstone. At most places it contains abundant nodules of phosphate. Regionally the green color and the nodules are the unit's most distinguishing characteristics. Typically the lower part of the formation has one or two layers composed almost wholly of phosphate nodules of many shapes and sizes (pl. 16B). Less abundant phosphate is scattered throughout the formation. 


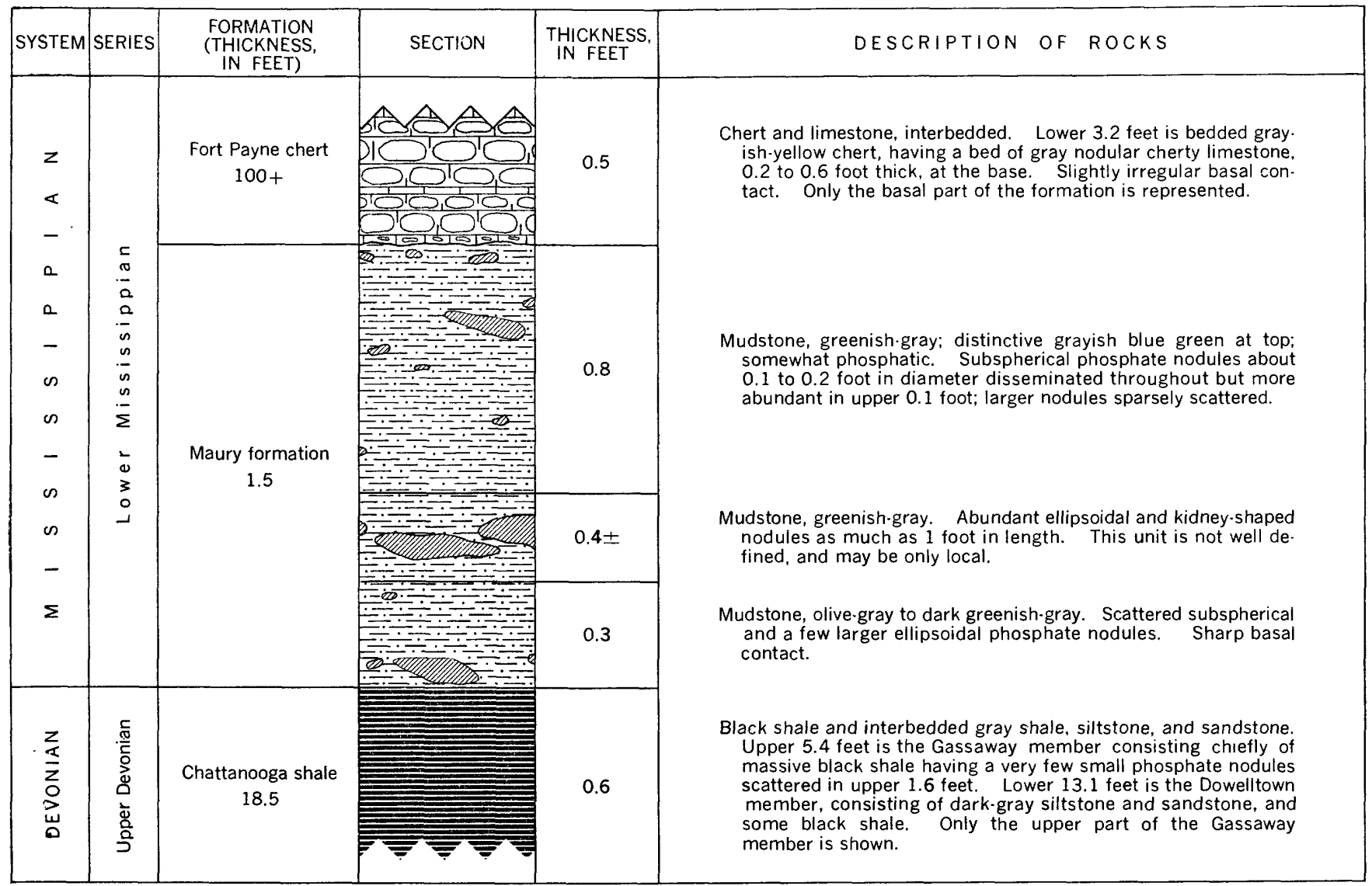

FIgURE 14.-Standard section of the Maury formation, locality 185 near Cross Key, Williamson County, Tenn.

At many places a few inches of gray claystone is at or near the base of the formation. At first sight it closely resembles the black shale of the Chattanooga, but it can be distinguished from that shale by its slightly brown hue, its more rapid weathering, and its lesser induration-it responds to a hammer blow with a dull thud, but the black shale produces a ringing noise.

Locally a little black shale lies just above the basal bed of gray shale. Commonly it is interbedded with the phosphate nodules, takes the place of the nodule layer where that layer pinches out, or overlies the nodule bed. In general appearance this shale is identical to the Chattanooga shale, although it contains a different conodont fauna (Hass, 1956, p. 24). At those places where the gray claystone or other distinctive bed of the Maury formation does not separate this black shale containing Mississippian conodonts from the black Chattanooga shale, it can only be distinguished from the Chattanooga by its fossil content.

The pinching and swelling of the beds in the Maury formation is illustrated in figure 15, a drawing of an outcrop near Nashville (loc. 203A).

This example shows that if one examined drill cores or exposures only a few feet wide, the lower 2 feet of the Maury would be interpreted inconsistently in the absence of paleontologic information.

The upper part of the Maury formation is commonly a claystone that weathers into hackly chips not fissile enough to be called shale. On fresh exposures the claystone is greenish gray; on weathered surfaces it is light green, olive green, or light blue green. Along most of the eastern and southern edges of the basin glauconite grains are rarely visible in either hand specimens or thin sections, but the green color may result from "pigmentary glauconite," a form described by Cayeux (1897). X-ray study in the survey laboratory indicates that the bright blue-green shaly "chips" that are common at the top of the Maury probably contain glauconite. These chips are commonly an inch or two long and are restricted to about the two top inches of the formation.

The claystone and siltstone and other rocks of the Maury formation weather more rapidly than most of the overlying and underlying rocks and yield a clayey material that is slippery when wet. On some unimproved roads, where outcrops are often poor, a greenish mud hole in the road and a few phosphate 


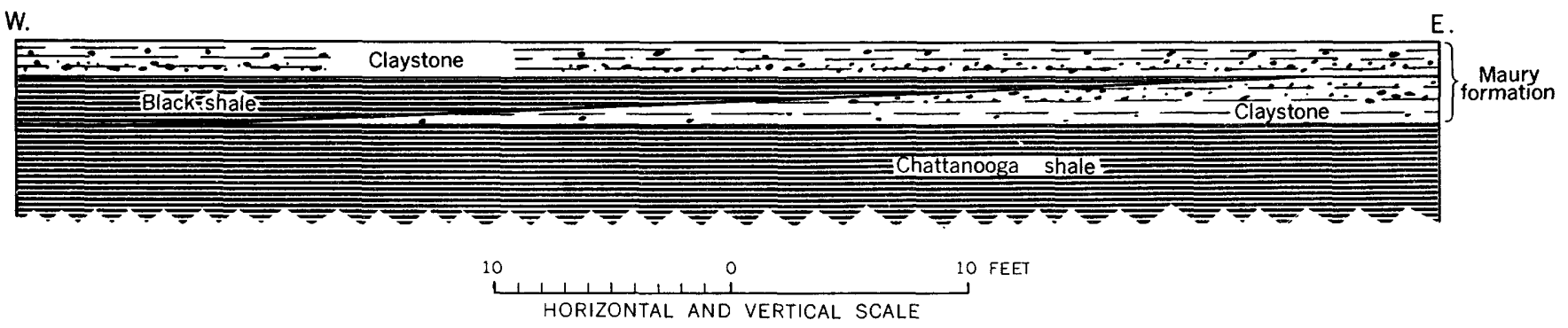

FIGURE 15.-Sketch showing apparent interfingering of the Maury formation and the Chattanooga shale. Two-foot wedges of black shale and phosphate nodule-bearing claystone pinch out within 50 feet. Black shale wedge at center is considered part of the Maury formation, but at the west end, and for 100 feet beyond, it is lithologically indistinguishable from black shale of the Chattanooga. Locality 203A.

nodules in the soil are sufficient to identify the position of the Maury.

Along much of the western edge of the Nashville Basin the Maury formation contains abundant glauconitic sandstone. At most places this overlies the phosphate nodule layer, but in some places it also encloses the nodules and extends to the base of the formation. At places where the Chattanooga shale is absent the lower part of the Maury is characteristically a glauconitic sandstone that contains granular or nodular phosphate.

In parts of the valley of Swan Creek, especially in Lewis and Hickman Counties, where the Chattanooga shale is missing, the Maury is composed largely of phosphatic debris that has been reworked from the former land surface.

On Red Mountain, between Birmingham and Bessemer, Ala., some of the road cuts show a foot or less of greenish mudstone underlain by a foot or less of purplish clay, and this by a few inches or a few feet of sandstone. The fine-grained beds have commonly been identified as Chattanooga shale. It seems more likely, however, as reported by Glover (1959, p. 143), that sedimentary rocks of Chattanooga age are absent on Red Mountain and that the material in question is an equivalent of the Maury formation. The sandstone is probably a basal phase of the Maury. These beds are overlain abruptly by characteristic Fort Payne chert.

\section{PHOSPHATE NODULES}

A description of the phosphate by Safford and Killebrew (1900, p. 141-142) is quoted here:

The Green shale is of interest in that it has generally imbedded in it concretions of calcium phosphate. These are roundish, from the size of marbles to that of a man's head, and in kidneylike, cakelike, and gourdlike forms of various sizes. They may be seen tightly packed together with little of the shale, as if so many cannon balls, in a layer from 8 to 10 , or exceptionally 18 inches in thickness; or else loosely disposed in the greenish shale, which itself is more or less phosphatic. The concretions, when broken, give out a strong fetid odor and show shells of lingulae. They contain 50 to 65 per cent of calcium phosphate. The bed is well developed in parts of Perry county.

Kidney forms of the above kind are now and then seen imbedded in the underlying Black shale.

The tightly packed nodules, where present, are in the lower part of the formation ( $\mathrm{pl} .13 \mathrm{C}$ ), and where the concentration is greatest they have their greatest variation in shapes and sizes. The loosely disposed phosphate is typically in the upper part of the formation where it assumes marblelike or thin platelike shapes. The platelike masses are as much as several feet long and are commonly parallel to the stratification, but in places they are at various angles to the bedding.

The thickness of the bed of tightly packed nodules is commonly about 6 inches to 1 foot but differs greatly in short distances. One of the best exposures is in a deep highway cut along the north approach to Hurricane bridge in DeKalb County, Tenn. (loc. 68), where the nodule bed ranges in thickness from about 3 inches to 2 feet (pl. 16B). At an outcrop in Jackson County (loc. 27) it is 2 feet thick at one place, but 50 feet away along the outcrop the nodules are absent. At a few places along the northeastern edge of the Nashville Basin two nodule layers are present, separated by a few inches of black shale (for example, loc. 27).

The matrix of the phosphate nodule masses differs greatly from place to place. At some outcrops the nodules are embedded in greenish siltstone or sandstone that commonly is glauconitic. Along the northern and northeastern edges of the Nashville Basin, where glauconite is sparse or absent, the matrix is a badly contorted impure dark-gray shale that is wedged between the nodules. In the western part of the area the abundant nodules are associated with a coarse glauconitic sandstone, which is in the lower part and which is grayish green to dusky blue green in color.

Where associated with fine sediments the nodules commonly have a massive appearance, but where they are associated with glauconitic sandstone they nor- 
mally contain a large percentage of easily recognized glauconite and quartz. Microscopic examination shows that both types contain abundant grains of the associated rock. Some nodules contain abundant oolites of phosphate commonly less than $1 \mathrm{~mm}$ in diameter; others have tiny spheres which are probably remnants of oolites but which are now either hollow or are filled with quartz, calcite, or pyrite.

A large proportion of the nodules contain one or more fossils that probably served as nucleii around which the calcium phosphate accumulated. Among the fossils that have been recognized are linguloid brachiopods, conodonts, cephalopods, crustaceans, bone fragments, and plant remains. Lloyd G. Henbest (written communication Feb. 10, 1953) of the Geological Survey identified probable spumellarian type radiolaria in some of the nodules; though poorly preserved, they show little or no fragmentation or deformation by compaction.

Microscopic study shows that the massive nodules from the eastern edge of the basin contain abundant minute grains of quartz, mica, calcite, and pyrite. The average diameter of most of these particles is about $0.005 \mathrm{~mm}$, which is about the minimum size of silt grains. Some grains are even smaller, in the size range of clay. These grains are about the same kind and size as those that make up the associated claystone or shale. Locally the quartz, calcite, and pyrite are concentrated in the spherical vacuoles, which are $1 \mathrm{~mm}$ or less in diameter. Similar study of a nodule from a coarser glauconitic sandstone matrix (loc. 196) shows at least 50 percent of the nodule to be inclusions of grains that make up the enclosing rock.

No detailed study has been made of the phosphate minerals in the nodules. Presumably the phosphatic part consists of collophane, a variety of apatite.

Chemical analyses of nodules taken at random from the conspicuous bed at locality 68 , along the north approach to Hurricane Bridge over Center Hill Reservoir, show about 30 percent $\mathrm{P}_{2} \mathrm{O}_{5}$ (table 10, p. 70).

The wide areal distribution of the phosphate nodule layer is one of the most remarkable characteristics of the Maury formation. The nodule layer is absent, however, in parts of the area studied. It is absent at most outcrops along the eastern edge of the Nashville Basin from southern DeKalb and White Counties southwest to the Alabama State line, a distance of 75 miles. It is also absent in the southern part of the basin as far west as the vicinity of central Giles and Marshall Counties, though at a few outcrops a few small phosphate nodules and thin phosphatic layers were observed. Farther south the nodule layer is present in outcrops in northern Alabama; it thins east- ward in the Sequatchie Valley. It is seen consistently in cores of water wells drilled in the vicinity of Huntsville, Ala. (P. E. LaMoreaux, oral communication) and it is present at many places farther south in Alabama.

The nodule layer must result from conditions that existed widely in the Early Mississippian epicontinental sea, and it seems likely that everywhere the layer is about the same age.

It is probable that the nodules formed on the sea bottom simultaneously with the slow accumulation of the mud, and shortly afterward. The abundance of the nodules (pl. 16B) seems to preclude the likelihood that they were formed long after deposition by a migration of phosphatic matter in the formation or even in the underlying Chattanooga shale. Seemingly the nodules are a chemical precipitate from the sea water, but the tabular masses that cut across the bedding seem to result from local migration and redeposition of the material after burial and compaction.

\section{EXTENT AND THICKNESS OF MAURY FORMATION}

The Maury formation is present at every examined outcrop where its stratigraphic position is exposed, and it continues without known exception across all the areas in the region of this study where the Chattanooga shale is absent ${ }^{3}$. Jewell (1931, p. 40-41) stated that the Maury is absent in most of Hardin County, Tenn., but we have recognized it at every outcrop of Chattanooga shale in that county, as elsewhere.

Northward into Kentucky the blue-green mudstone becomes thinner but the phosphate nodules continue across the State and even into Indiana, where Campbell assigned them to the Falling Run member of his Sanderson formation. In much of Kentucky, however, the only recognizable Maury is a layer of phosphate nodules at the base of a succession of greenish or bluish shales that have been generally called the New Providence shale.

The thickness of the Maury formation commonly is between 1 and 4 feet, though its thickness is known to range from a few inches to at least 7 feet. At most places around the Nashville Basin it is about 2 to 4 feet thick. Some of the thinnest observed outcrops are in and near the northwestern part of Davidson County where it is a phosphate-rich glauconitic sandstone about 4 to 12 inches thick. On the south edge

\footnotetext{
3 The only outcrop in Tennessee observed during this study where the presence of the Maury formation is in doubt is locality 88 at Horseshoe Bend on Caney Fork, now below normal pool level of Center Hill Reservoir. On the basis of conodonts found between 1.7 and 2 feet below the Fort Payne chert, Hass (1956, p. 30) assigned no beds to the Maury. The senior author of this report believes the topmost 1.7 feet of beds, which have a greenish color, should be assigned to the Maury.
} 
of Chattanooga, at St. Elmo, it is about 5 feet thick, as it is at several outcrops southward for 50 miles to the vicinity of Fort Payne, Ala. In a highway cut at Blanche, DeKalb Co. Ala., where the formation dips about 80 to 85 degrees, it is about 7 feet thick. An unusual feature at the Blanche outcrop is a 2-foot bed of black shale, 3 to 5 feet from the top of the formation.

At a few places, where the Maury formation grades into an overlying shale, its upper contact can not be positively located. Thus, at one place near Theta, in Maury County, Tenn., (loc. 181), the formation is about 8 feet thick the basis of an upper limit determined by any satisfactory criterion.

\section{AGE AND FOSSIIS}

Opinions on the age of the Maury formation have been almost as diverse as those concerning the underlying Chattanooga shale, with which it is so closely associated. Those who have treated it as part of the Chattanooga have naturally given it the same age assignment. The following quotation from Campbell $(1946$, p. 895$)$ not only summarizes some of these views but illustrates the attention that has been given to this thin unit:

Safford (1869) included a layer of "kidneys," at the top of the black shale, as a part of the black shale group of Devonian age. Safford and Killebrew (1900) named the Maury and defined it as a bed of green or greenish shale from a few inches to 4 to 5 feet thick, which contains concretions of calcium phosphate, in a layer 8 to 10 , or exceptionally 18 inches thick, and included it with the Mississippian. ** Swartz (1924) regarded the Maury as "the broadly overlapping basal bed of the Ridgetop rather than of the Chattanooga shale, and as a condition not a chronological unit." Bassler (1932, p. 143) regarded the Maury as the "introductory stage of the succeeding formation no matter what that may be." According to Klepser (1937) and as quoted by Stockdale (1939), the Chattanooga everywhere grades upward into the Maury, and the Maury into the New Providence and Fort Payne. The Chattanooga and Maury are time-transgressing units representing the basal shore phases (the Chattanooga the more shoreward) of the sea advancing southward. The Chattanooga is in great part post-Kinderhook (almost entirely Osagian); in Alabama it is Warsaw, and possibly St. Louis, in age according to Klepser.

As Campbell considered the Gassaway member of the Chattanooga shale to be of Mississippian age, he necessarily assigned the Maury to the Mississippian.

Hass (1956, p. 23-24) concluded, from a study of the conodonts, that in most areas the entire Maury formation is of Kinderhook (Early Mississippian) age, but in a small area in north-central Tennessee the basal bed appears to be of very late Devonian age, and in some places the uppermost part is probably of early Osage age. From this it appears that the 3 or 4 feet of the Maury formation represents most, if not all, of Kinderhook time. The beds tend to have a more or less uniform lithologic succession, and at most places there is no obvious evidence of erosional breaks within the formation or at its top. It seems likely therefore, that the Maury formation, where more complete, represents the entire accumulation on the bottom of a quiet sea that existed throughout most or all of Kinderhook time. Elsewhere sedimentary beds of that age are many times as thick.

Other sparse fossils in the Maury formation include cephalopods, crustaceans, bone fragments, and plant remains. A few Orbiculoidea and Lingula were found, but the very few larger brachiopods that were found are poorly preserved and are not suitable for specific identification. Mention has already been made of the Radiolaria identified in the phosphate nodules (p. 66). Except in the nodules, fossils are generally found in the Maury only with difficulty.

\section{LOWER AND UPPER CONTACTS}

The base of the formation is here defined as the contact between the black shale of the chattanooga and the greenish gray claystone, siltstone, or sandstone, or the conspicuous bed of phosphate nodules: where those beds are absent and black shale encloses or overlies the main bed of nodules, the contact is at the base of the lowest conspicuous nodule layer. At outcrops where the phosphate nodule layer or other distinctive lower bed of the Maury formation is absent, any black shale bed that elsewhere contains the nodules or that would overlie them, is necessarily classed as Chattanooga shale; only the conodonts would reveal its Mississippian age and thus its age affinity with the Maury formation (fig. 15). South of Kentucky the contact is abrupt nearly everywhere. In much of Kentucky the contact appears more gradational and is more difficult to identify.

Where the Chattanooga shale is absent and the Maury formation lies on older rocks, it is obvious that an unconformity is present, and physical evidence of it is abundant.

It has already been stated in discussing the Chattanooga shale (p. 36) that at some places an inconspicuous erosional surface seems to separate the shale from the Maury formation. At most places no physical evidence of an unconformity was found, though Hass $(1956$, p. 23$)$ believed that the change in conodont assemblages denotes some kind of break in sedimentation.

The upper contact of the Maury formation has been variously placed. Where the Maury is overlain by a shale formation, the gradation from one to the other 
is so gradual that in many places it is difficult to select a satisfactory boundary, as at the Theta outcrop already mentioned (loc. 181). At most such places the phosphatic Maury is either glauconitic or has a distinctive green color, but it is not calcareous. The overlying shale, however, is not phosphatic or glauconitic but usually is calcareous and is likely to contain subordinate beds of chert. At these places the upper contact of the Maury is placed arbitrarily where the phosphate and glauconite disappear or where shale becomes calcareous, whichever is lower. At some places a conspicuous chert bed near the horizon where the contact would be expected constitutes a satisfactory basal bed for the overlying formation.

Where the Fort Payne chert or its local basal unit of crinoidal limestone overlies the Maury formation the contact is abrupt. The characteristic brilliant blue-green shaly chips that are present at many places at the top of the Maury are also present at many places in the lower 2 or 3 inches of the Fort Payne (pl. $16 C$ ). Their origin is unknown, but they do not appear to be reworked chips of a previously deposited bed. Where both formations are weathered, the contact can usually be located within a vertical distance of an inch or two between weathered phosphate nodules of the Maury and quartz-lined geodes of the Fort Payne.

The lithologic contrast between the soft greenishgray claystone of the Maury formation and the hard massive chert of the Fort Payne chert is suggestive of an erosional break at that horizon, but there is no known evidence of an unconformity. The Fort Payne chert is a lateral equivalent of the shales that elsewhere overlie the Maury conformably; thus there is no reason to believe that an erosional break separates the Fort Payne from the Maury. Instead, the contact probably represents a relatively sudden change to an environment that favored the deposition of siliceous limestone on the sea bottom.

Were there a widespread erosional break at the top of the Maury formation, it is highly probable that the thin unit would have been entirely removed at some places. As no place is known where it is missing or where its upper surface is irregular, its continuity is an additional indication of a conformable contact. Such irregularities as do exist in the thickness and composition probably result from slightly varying conditions of deposition and availability of sediment from place to place.

\section{SIGNIFICANCE}

The Maury formation is believed to be a transitional unit that marks a gradual regional change from the poorly oxygenated waters of the Late Devonian sea to the well-aerated sea of Mississippian time. As already explained (p. 36), Hass (1956, p. 23) interpreted the paleontologic evidence to indicate that some of the topmost beds of the Chattanooga shale are absent in large areas, but physical evidence of an unconformity at the Chattanooga-Maury contact is scant. Deposition may have been interrupted locally by a shallowing of the sea at the end of Devonian time and perhaps by some warping and planation of the sea bottom. Otherwise deposition seems to have been almost continuous from the Chattanooga shale to the Fort Payne chert or its lateral equivalents.

The significance of the abundant phosphate nodules and glauconite is not known. Many writers have speculated on the origin and significance of these minerals, but it is by no means certain that any one of the theories will explain the mineral assemblage in the Maury or the phosphate in the upper part of the Chattanooga. As no special studies of these minerals were made during the present investigations, no theories are offered to explain their presence.

The association and stratigraphic significance of nodular phosphate and glauconite in a thin unit representing an extended period of time was discussed by Goldman (1922). He cited a number of areas where concentrations of these two minerals, with a minimum of detrital material, are indicative of important stratigraphic breaks. To what extent this concept can be applied to the Maury formation is uncertain, but it is likely that the phosphate was precipitated when clastic sedimentation was extremely slow, as it is where it is being precipitated today (Dietz and others, 1942).

Many writers who have discussed the origin and significance of glauconite thought that the mineral is formed in a somewhat reducing marine environment of slight sedimentary influx (for summary of these opinions, see Cloud, 1955). In most respects the Maury formation seems to fit these ideas, though it may be noted that the glauconite is not apparent in those parts where the very fine texture of the rocks most strongly indicates slow deposition but is abundant in areas where a sandier facies predominates.

The small amount of clastic material that accumulated during Kinderhook time in the area studied is probably primarily a result of the increased distances from source areas. At the end of the Devonian period the epicontinental sea expanded broadly over its peneplained margins and covered all the islands that had existed in the Chattanooga sea. Source areas, which had provided only small amounts of sediment in Late 
Devonian time, were now separated from the area by a much greater expanse of water. Most of the clastic sediment that makes up the Maury formation is probably primarily the sediment that formerly made up surficial deposits of the peneplained areas that were submerged. Most of this material was probably stirred up numerous times by currents or waves before final deposition occurred.

The subsequent onset of more abundant deposition, chiefly of chert, shale, and limestone, must have been caused by significant changes in the nature of the epicontinental sea or the surrounding land, or both.

\section{ECONOMIC GEOLOGY}

For many years the black shale (locally known as black slate) has been mistaken for coal, which it somewhat resembles in appearance, and many optimistic persons have vainly dug into the hillside hoping that fresh material, farther back from the outcrop, would be useable coal. Hopes have doubtless been strengthened by the observation that the shale will burn slowly if thrown onto a fire and will burn in a forge. The burning, however, results from the organic content which, when heated, breaks down to form oil and gas, as discussed later. The remaining rock, or ash, which has the same shape and size as before burning, amounts to fully 75 percent by weight of the original rock, as compared with 15 percent or less in most commercial coals.

The Chattanooga shale has been used in one small plant as a source of pigment, but, so far as known to us, it has not otherwise been used commercially.

Locally large slabs have been split and used for door steps and flagstones, but it disintegrates within a few years. It cannot be split and trimmed with sufficiently smooth surfaces to be used as slate.

\section{IIGHT-WEIGHT AGGREGATF}

When the black shale is burned under proper conditions, it bloats and becomes light enough either to float or almost to float on water. Experiments have been conducted in the use of burned shale as a lightweight aggregate for concrete, but the results of such experiments, so far as we know, have not been published. It is understood that in Sweden light-weight building blocks, having a specific gravity of about 0.8 , are made from the carbonaceous Alum shale. If the Chattanooga shale were ever to be mined for the extraction of any of its ingredients, the readily available shale residue might well be used for similar lightweight building blocks.

\section{OII SHAIE}

The Chattanooga and related black shales have long been known as low-grade oil shales, but their yield is so much lower than that of some of the western oil shales that no serious attempt has been made to extract the oil on a commercial basis. Crouse (1925, p. 62) reported that the shale in Kentucky will yield as much as 16 to 21 gallons of oil per ton and 3,000 to $4,000 \mathrm{cu}$ $\mathrm{ft}$ of gas having a heat value of $337 \mathrm{Btu}$. He did not state the locations from which the samples were taken. Samples taken during the present investigation from 39 feet of black shale in Kentucky, at locality 4, were assayed in the laboratory of the U.S. Geological Survey by the modified Fischer retort method. These assays show a maximum oil yield of 17.5 gallons per ton for a 2-foot interval (at the top), an average of 14 gallons for the upper 10 feet, and an average of about 10 gallons for the entire 39 feet.

Oil assays of many samples taken in Tennessee during the present study are summarized on plate 17 . Results of additional assays were published by Cuttitta $(1958 \text {, table } 9)^{4}$. No obvious relationship was found between the indicated oil yield and other characteristics of the three black shale units in the Tennessee area. Plate 17 illustrates this point if it is borne in mind that the topmost black shale (upper unit of the Gassaway member) is the most massive, darkest in shade, and highest in uranium content and that the lowest black shale unit (lower unit of the Dowelltown member) is the least massive, lightest in shade, and lowest in uranium content. The gray beds are low in both uranium content and oil yield.

These assays indicate that the Chattanooga shale of Tennessee is not likely to be exploited as an oil shale in the near future. If, however, large quantities of the shale were to be worked for one or more other constituents, the oil and gas might be extracted as by-products.

Although no minimum standards for potentially exploitable oil shale have been established in actual practice, the U.S. Geological Survey uses a 15-foot bed that will yield 15 gallons per ton as the lower limit in calculating oil shale reserves. At present all significant experimentation in mining and retorting oil shale is confined to grades yielding more than 25 gallons per ton. As the Chattanooga shale does not meet even the minimum specifications, it is not currently considered in estimating national reserves of oil shale.

4 See table 1, page 6 , this report, for the stratigraphic identification of the sample numbers shown by Cuttitta. 
At one time about 10 gallons of oil per ton were reported (Nelson, 1913, p. 159-160) to have been obtained as a by-product in the process of treating the Chattanooga shale for use as a paint pigment.

\section{PHOSPHATE}

Phosphate, like oil and gas, is a possible by-product if large quantities of Chattanooga shale were to be processed for one or more other ingredients. At most places the lower part of the Maury formation has a phosphate nodule bed, commonly a few inches to 1 foot thick and, if operating conditions permitted, this bed might supply a profitable phosphate by-product. Determinations of the phosphate content of these nodules are given in table 10. (The phosphate content of a rock is commonly reported either as phosphoric oxide, $\mathrm{P}_{2} \mathrm{O}_{5}$, or as tricalcium phosphate, $\mathrm{Ca}_{3}\left(\mathrm{PO}_{4}\right)_{2}$; the latter, known commercially as bone phosphate of lime or B. P. L., is 2.18 times the $\mathrm{P}_{2} \mathrm{O}_{5}$ content.)

TABLE 10.-Phosphate content of nodules from the Chattanooga shale and Maury formation in Tennessee

\begin{tabular}{|c|c|c|c|c|c|}
\hline \multicolumn{3}{|c|}{ Locality } & \multirow{2}{*}{$\underset{\text { (percent) }}{\mathrm{P}_{3} \mathrm{O}_{5}}$} & \multirow{2}{*}{$\underset{\text { (percent) }}{\mathrm{Ca}_{3}\left(\mathrm{PO}_{4}\right)_{2}}$} & \multirow{2}{*}{ Analyst } \\
\hline $\begin{array}{l}\text { No } \\
\text { (table } \\
\text { 13) }\end{array}$ & County & Description & & & \\
\hline \multicolumn{6}{|c|}{ Maury formation } \\
\hline 68 & DeKalb.. & & $\begin{array}{l}29.9 \\
29.3 \\
33.2\end{array}$ & $\begin{array}{l}65.2 \\
63.9 \\
72.4\end{array}$ & $\begin{array}{l}\text { Charles Milton } \\
\text { Harry Levine } \\
\text { W. P. Tucker }\end{array}$ \\
\hline \multicolumn{6}{|c|}{ Chattanooga shale } \\
\hline $\begin{array}{l}36 \\
56\end{array}$ & $\begin{array}{l}\text { Jackson.-. } \\
\text { Putnam.- } \\
\text { Smith.... }\end{array}$ & $\begin{array}{l}\text { Top } 1 \mathrm{ft} \\
2-2 \mathrm{ft} \text { below top } \\
2-2.3 \mathrm{ft} \text { below top. } \\
\text { Top } 1 \mathrm{ft} \\
1.9-3.1 \mathrm{ft} \text { below }\end{array}$ & $\begin{array}{l}26.0 \\
20.8 \\
23.2 \\
27.3 \\
26.3 \\
28.9\end{array}$ & $\begin{array}{l}56.7 \\
45.3 \\
50.6 \\
59.5 \\
57.3 \\
63.0\end{array}$ & $\begin{array}{l}\text { Leonard Shapiro } \\
\text { Joseph Budinsky } \\
\text { Do. } \\
\text { Do. } \\
\text { Do. } \\
\text { Do. }\end{array}$ \\
\hline 66 & Putnam.- & $\begin{array}{l}\text { top. } \\
\text { Several nodules in } \\
\text { upper } 6 \mathrm{ft} \text {. }\end{array}$ & 28.0 & 61.0 & Do. \\
\hline
\end{tabular}

This phosphate is about medium grade and is somewhat lower grade than most phosphate mined in western Tennessee, much of which has ranged between 70 and 80 percent B. P. L. As the analyses given in table 10 are of the nodules themselves, the phosphate content of the entire bed of nodules, as it would be mined, would be somewhat less. In the massive black shale, which is the richest in uranium of the Chattanooga beds, the $\mathrm{P}_{2} \mathrm{O}_{5}$ content is only 0.1 to 0.2 percent.

The basal sandstone of the Chattanooga shale in Hickman, Lewis, and Perry Counties locally contains an abundance of phosphate. This "blue phosphate" was mined at one time, but its thickness and B. P. L. content vary to such an extent that it has not been mined commercially for many years.
Nelson (1913, p. 149-150) mentioned an attempt to mine the so-called black or kidney phosphate in the Maury formation. This unsuccessful venture was near Boma in Putnam Co.

\section{PIGMENT}

The only known successful industrial use of the Chattanooga shale is as a source of black pigment. Nelson (1913, p. 159-160) reported its use at Nashville where, after the extraction of about 10 gallons of oil per ton by retorting, this shale was ground and mixed, then made into a $" * * *$ natural carbon paint by adding a sufficient amount of linseed oil and manganese dryer." Later Whitlatch (1948) described a small plant near Franklin, Williamson County, Tenn., that had produced an impure carbon black since 1932. Unless new and vastly greater demands for such pigment should arise, this use of the Chattanooga shale appears unlikely on a large scale. As a by-product in connection with some other exploitation of the shale, the pigment might be manufactured on a much larger scale.

\section{SULFURIC ACID}

The black shale contains about 10 percent pyrite or marcasite. Quite possibly the large-scale utilization of the shale for some other purpose would also permit a profitable byproduct manufacture of sulfuric acid, especially if the other process were such as to require fine grinding or roasting of the shale.

\section{URANIUM}

\section{SAMPLING}

During the course of the studies here reported, chiefly between 1947 and 1954, about 3,000 samples were taken from about 150 outcrops and 75 drill cores. Except in outlying or fringe areas or places of poor exposures, most of the sampled outcrops are within 5 miles of one another, and some are much closer. Much the greater number of samples were taken from central Tennessee, either because shale from other areas was found to have markedly less uranium or because such factors as thick overburden, structural complexities, and thinness of strata make the shale of less economic interest.

In 1948 a drilling program to obtain samples of the shale at depth and at a considerable distance from outcrops yielded four cores from DeKalb and White Counties.

In 1949 a 100-foot adit was driven into the Chattanooga shale near the east approach to the old Sligo bridge (loc. 79) by the Tennessee Valley Authority to obtain bulk samples for the Geological Survey for laboratory experimentation and to learn something of 
the mining characteristics of the shale. In 1953 this opening supplied bulk samples for experimental work at Columbia University.

In 1953 a more intensive drilling program was conducted by the U.S. Bureau of Mines for the Atomic Energy Commission, in cooperation with the Geological Survey, in order to test one area in detail and to explore other areas. Seventy-one cores were obtained, all of NX size (21/8 inches in diameter). Seven were from two sites east of Smithville, Tenn., that had been selected by the Bureau of Mines for study as possible mine sites-one site near the Sligo adit, and one on the north side of Pine Creek (fig. 17). The other 64 cores were to obtain samples for uranium analyses, and for geological information. Of these 64 cores, 36 near Smithville were at spacings of about a mile or less, 19 along the Northern and Eastern Highland Rims were at spacings of 10 to 17 miles supplemented by 2 others close to one site, and 7 on the Sequatchie anticline were at irregular spacings. Because these cores have been the basis for estimates of uranium tonnages and many have been studied by other investigators and because most of them are available for future studies, the locations of all the hole sites are shown in figures 16 and 17.

The seven cores from the mine-site localities included about 50 feet of the overlying Fort Payne chert, and were subjected to engineering tests (Blair, 1956). The other 64 cores from the holes drilled in 1953 were sawed lengthwise into halves and quarters. One quarter of each core was sent to the Survey laboratory for uranium analysis, and another quarter was turned over to the Bureau of Mines for permanent storage. Quarters of 35 cores were given to Dr. T. F. Bates for studies at Pennsylvania State University, and quarters of 28 cores were given to Dr. P. B. Stockdale for studies at the University of Tennessee. A few halves or quarters were supplied to other investigators for special studies, and the halves or quarters of the remaining cores are retained by the Geological Survey. Results of the drilling on the Eastern Highland Rim were reported by Kehn (1955).

\section{DETERMINATION}

All the outcrop and drill-core samples were analyzed for their uranium content in the Geological Survey laboratory in Washington under the general supervision of Irving May, Frank S. Grimaldi, and Francis Flanagan. The uranium content of splits of many of the samples was also determined in other laboratories.

All samples were checked for their equivalent uranium content by standard radiometric methods. All promising samples, as well as many others were then further checked by fluorimetric methods. The fluorimetric methods available in the later stages of the work are believed to produce determinations having a precision ob about \pm 0.0005 percent, or 5 parts per million. Many of the samples whose uranium content had been determined earlier by the somewhat less precise methods then available, were re-analyzed to this greater precision. For nearly all samples from the Gassaway member the uranium content was determined by fluorimetric methods, but for a large number from the Dowelltown member only radiometric methods were used.

\section{RELATIONS}

A synthesis of the large volume of analytical data established the following facts regarding the association of the uranium:

1. The five lithologic units of the Chattanooga shale contain distinctly different amounts of uranium; the three richest are those that constitute the Gassaway member, and the richest single one is the upper unit of the member.

2. The uranium content of a given stratigraphic unit is nearly uniform for distances of many miles.

3. The darkest and most massive of the black shales have the most uranium, and the gray beds and sandstone have the least.

4. Shale containing phosphate nodules has less uranium than the nonphosphatic shale.

5. Coalified plant remains contain more uranium than any other type of rock.

Analyses of the large number of outcrop and drill core samples from the Eastern Highland Rim show strikingly the uniformity of the uranium content in given stratigraphic intervals over large areas. For 50 miles, from central DeKalb County to southern Coffee County, the uranium content of the shale shows no marked departures from that shown in table 11.

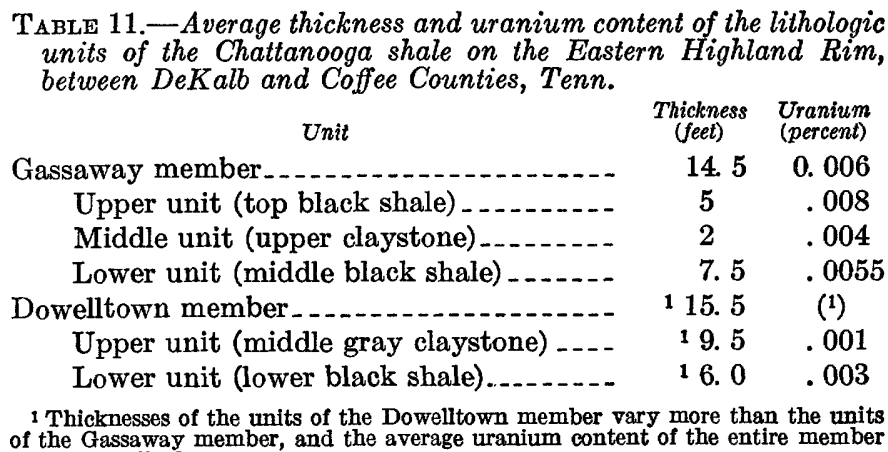
varies accordingly.

Gamma-ray logs of the Chattanooga shale, if on a sufficiently large scale, show this stratigraphic control of the uranium (fig. 18).

\section{ORIGIN AND DISTRIBUTION}

The most uraniferous parts of the formation are the most massive, the darkest in color, the most pyritic, and 


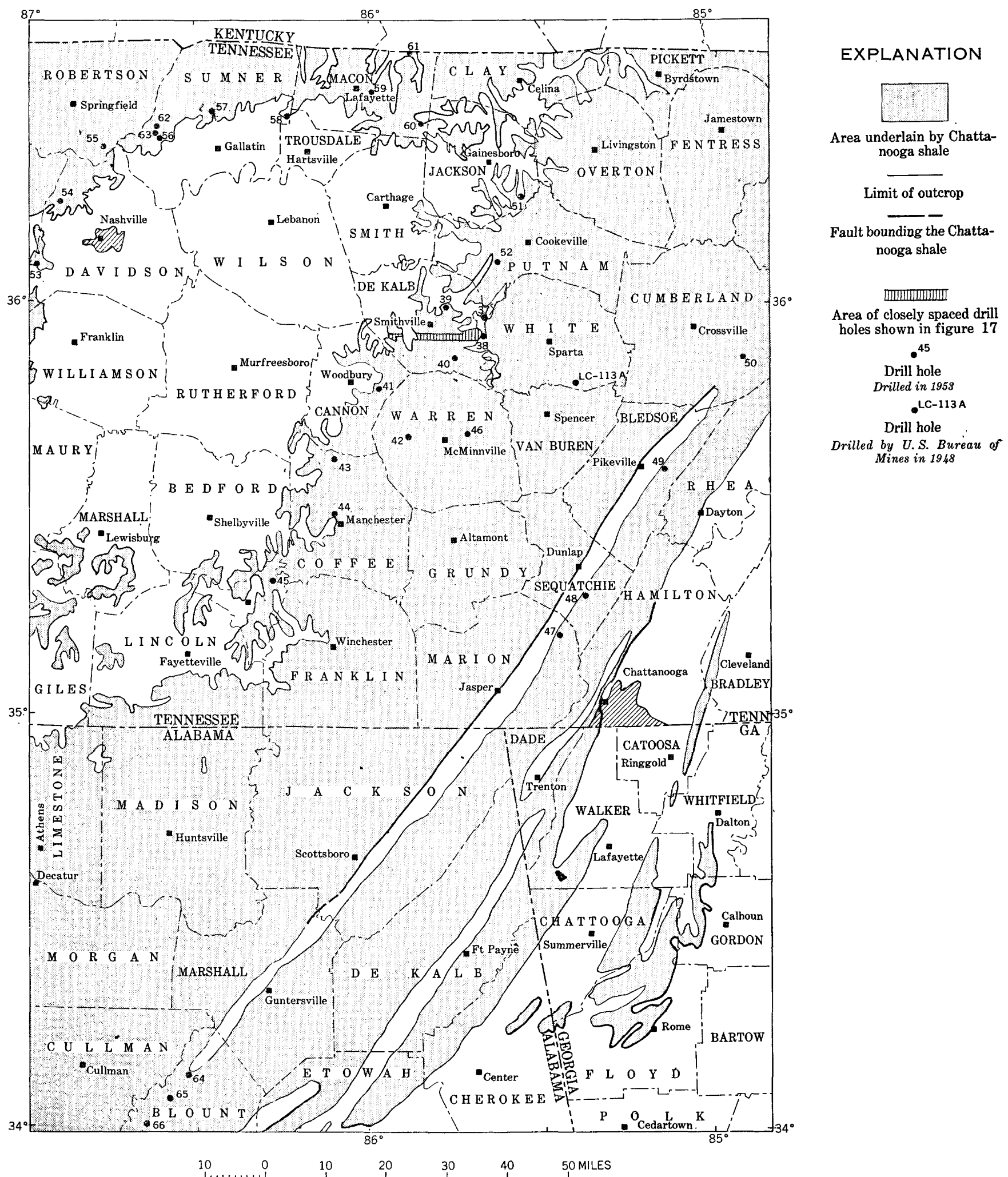

FIGURE 16.-Localities of drill holes in Chattanooga shale. See further explanation on figure 17. 

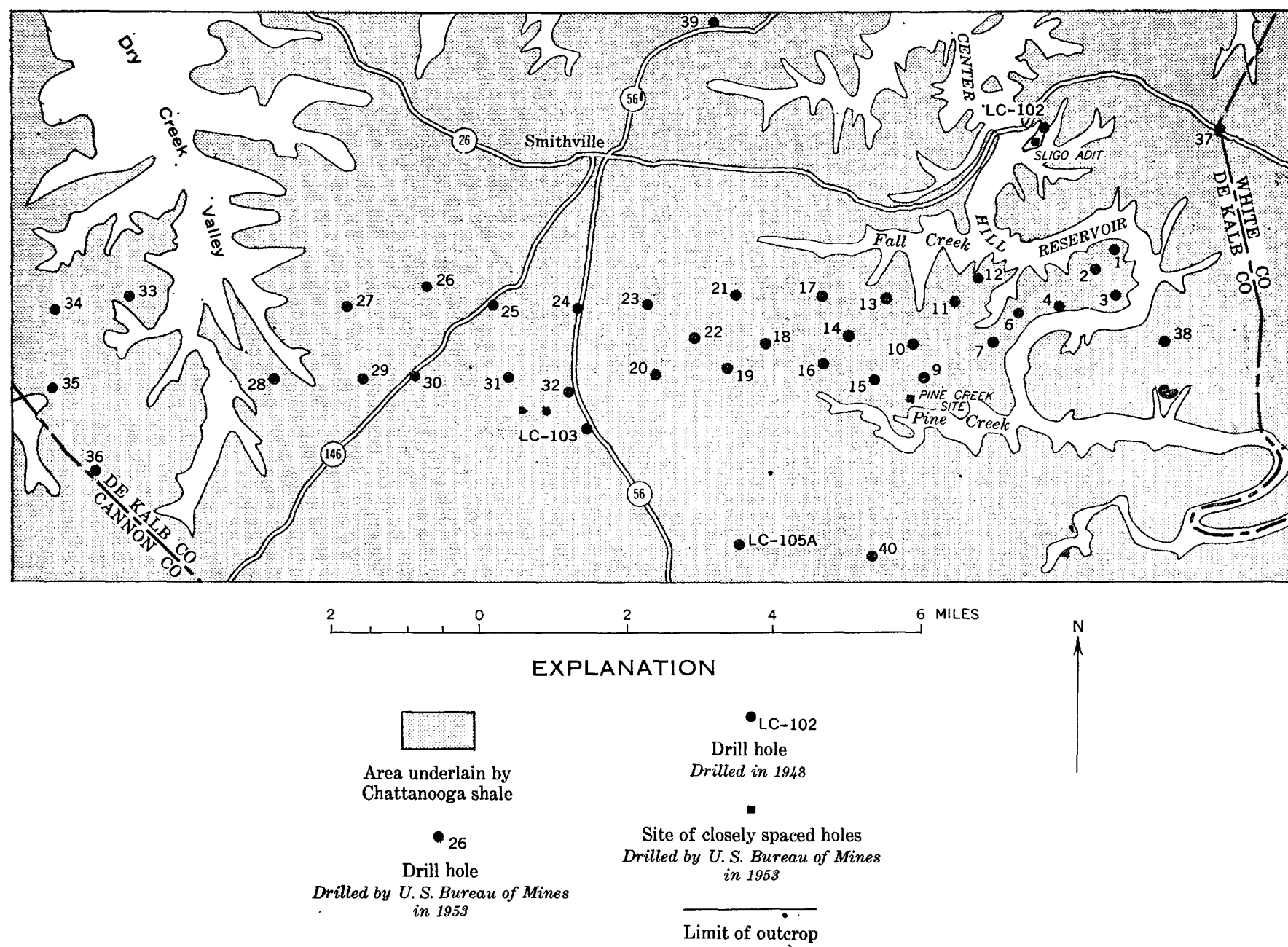

FIGURE 17.-Localities of drill holes near Smithville, Tenn.

probably the richest in organic matter. To date no uranium mineral has been found in the shale, and all attempts to identify a uranium-bearing compound have been unsuccessful. Studies of selected specimens have shown that some organic-rich parts contain more than average quantities of uranium (as high as 0.033 percent), whereas pyrite samples do not. Experiments by Moore (1954) showed that plant matter and low-rank coal have a strong affinity for uranium in solution. Breger and Deul (1956) reviewed a large body of information regarding the association of uranium with organic matter and concluded (p. 509):

There can no longer be any question *** that carbonaceous materials of various types play an important role in the secondary concentration of uranium. $* * *$

Uranium is not genetically associated with the carbonaceous substances, but it is collected by these substances during its migration.

It is generally accepted that the black mud that formed the Chattanooga shale accumulated in unoxygenated waters rich in plant fragments and sulfur acids, and it is probable that the sediments accumulated with extreme slowness. The paucity of clastic material resulted from the great distance of any major source area and from the inability of the nearby peneplained area, which was predominantly of limestone, to supply much sediment. Organic debris, on the other hand, was. relatively abundant, being supplied both by sluggish streams from the land areas and by algae and other plants that lived on or near the surface of the sea. The plant matter that sank into the oxygen-poor lower water was preserved from decomposition. Soluble iron available in the sea water combined with sulfide ions to form minute particles of iron-sulfide as disseminations in the black mud. Uranium probably was brought to the sea in fairly normal amounts from decomposing rocks in distant areas, was spread widely in the sea, was abstracted from the water by the abundant organic 


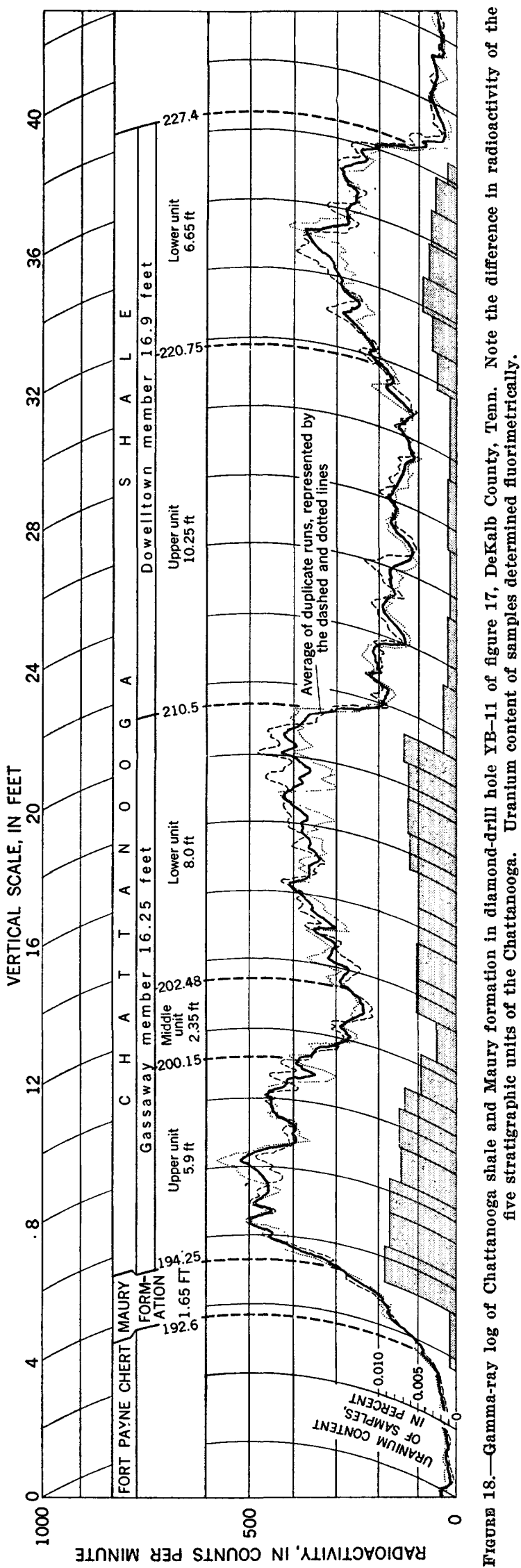


debris in the bottom mud. The precipitated uranium is probably thoroughly disseminated as submicroscopic specks or films on the plant debris. ${ }^{5}$

Time was probably an important factor in the concentration of the uranium, for the longer the individual plant particles were exposed to the water, the more uranium they could acquire. In other words, the slower the accumulation of clastic mineral matter in the sea, the richer the mud in uranium. Further, the higher the ratio of the organic matter to the clastic mineral matter, the higher the uranium content that may be expected in the shale.

Geographic location, other factors being equal, probably favored certain areas. Thus, if the chief source of the uranium was the crystalline rocks of the southern Appalachian and Piedmont area, as seems likely, the mud closer to the eastern or southeastern shore of the sea would be expected to have a somewhat higher uranium content. On the other hand, where a greater quantity of clastic sediment reached the sea, as in northeastern Tennessee, the formation is thicker and the uranium content lower.

So long as normal quantities of uranium were being brought to the sea, differences in the uranium content of the shale would indicate differences in chemical condition of the sea water, rate of deposition of clastic minerals, length of time individual plant particles were exposed to the sea water, and, to some extent, proximity to the supply of uranium reaching the sea.

A calculation was made by W. W. Rubey (oral communication) of the hypothetical rate of accumulation of uranium in a sea like the one we envision. He called attention to the statement by Koczy $(1954$, p. 126) that present-day streams are carrying to the ocean about 1 microgram of uranium per liter of water. Combining this estimate with that by Langbein and others (1949, p. 4) of the total present annual runoff from all the continents, it appears that about 40,000 tons of uranium are carried to the ocean each year. If this were precipitated uniformly over the present-day sea bottom, 10$15 \times 10^{-9}$ gram of uranium would be precipitated in each square centimeter per year. If this same rate of precipitation existed during the 5 million years that the Chattanooga sea is assumed to have covered the area, it would account, after allowing for radioactive decay, for an average uranium content of the entire Chattanooga

\footnotetext{
5 After this manuscript was prepared, Kinney and others (1958, p. 24) expressed somewhat different opinions, based on studies of the organic content of the shale. They concluded "**** these results seem to indicate, in accord with antoradiographic and other investigations, that the $U$ is deposited more or less evenly throughout the shale constituents. *** and finally it appears that; although the $U$ is probably deposited in the shale because of the presence of organic matter, it is not associated with either the mineral matter or the organic matter exclusively, because neither the ash content nor the carbon content *** bears any relationship to the percentage of uranium."
}

shale of 0.002 to 0.003 percent. These figures are very close to the actual average uranium content of the several units of the Chattanooga shale (table 11).

It must be realized, as Rubey pointed out, that various modifications could be made in the assumed rate and conditions of deposition, some of which would increase and others of which would decrease the amount of uranium expectable in the shale. The significant feature of these calculations is that they yield figures on the same order of magnitude as the amount of uranium in the shale, not figures that are 10 or 100 times greater, or only $1 / 10$ or $1 / 100$ as great. This being true, there appears to be no need to seek abnormal means to explain the introduction of the uranium into the shale, such as subsequent ground-water action or igneous emanations.

\section{REGIONAL VARIATIONS IN CONTENT}

The large volume of available data has established beyond reasonable doubt fairly definite regional trends in the uranium content of the Gassaway member of the shale. The uranium content of the Dowelltown member is so consistently low that no regional studies of its trends were made. Table 11 shows the averages of the Gassaway and the Dowelltown on the Eastern Highland Rim of Tennessee between DeKalb and Coffee Counties.

Detailed study of the assays of the Eastern Rim samples shows no large variation in the uranium content of the Gassaway member within a distance of 50 miles, and many of the small variations are explainable by the local differences in thickness of the individual units. (figs. 9, 10.) In fact, of the 36 closely spaced cores in the Smithville area (referred to as the Youngs Bend drilling area) only four cores had an average uranium content that differed from the 0.006 percent average by as much as 0.0005 percent. The chief trend apparent from the Eastern Highland Rim area cores is a slight increase in thickness of the Gassaway member in the easternmost holes (pls. 11B, 12) and a slightly higher average uranium content for this member in that direction (table 12).

\begin{tabular}{l} 
TABLE 12.-Thickness and uranium content of samples of the \\
Gassaway member from the more eastern drill holes compared \\
with the average from holes on the Eastern Highland Rim \\
\hline Loeality (pl. 1; table 13) \\
\hline
\end{tabular}

South of Coffee County the lower units of the Gassaway member, as well as those of the Dowelltown, are 
absent, and only about 5 or 6 feet of the upper unit, representing that part that does not contain phosphate nodules, is present. Scattered samples indicate that in this southern area also the unit has a fairly high uranium content but is too thin to be of economic interest.

North from Smithville the uranium content decreases gradually in two respects: First, the beds of black shale having scattered phosphate nodules appear at the top of the upper unit of the Gassaway and their uranium content is commonly only about 0.004 percent; second, the remaining part of the Gassaway, even with the phosphatic beds excluded, tends to have a slightly lower uranium content. This trend continues fairly steadily into southern Kentucky as far as the shale is exposed. Still farther north, where the shale crops out around the Lexington Basin, its uranium content is even lower, about 0.003 percent. This northward decrease in uranium content probably results from the greater thickness of the shale in that direction, presumably an illustration of the principle that more rapid deposition is accompanied by a lower uranium content.

On the northern rim of the Nashville Basin the uranium content is lower at most places than in the DeKalb-Coffee County area, though some cores of the Gassaway member from northern Davidson County and western Sumner County have uranium contents of 0.0055 to 0.006 percent. As the richer beds are only about 10 feet thick, the reason for the low uranium content is not clear. Perhaps, as has been postulated, it is because much of the uranium was abstracted from the sea water by the bottom mud before it had a chance to get this far from its eastern source.

Outcrop samples and four cores from the Sequatchie anticline of eastern Tennessee show higher uranium contents than others. These indicate that the entire Gassaway member, which is here 11 to 21 feet thick, has a uranium content ranging from about 0.006 percent to about 0.007 percent. In the same cores, the most uraniferous 10 to 15 feet consistently contains 0.007 to 0.008 percent uranium. The data are much too scant and the beds are too disturbed by folding and possible faulting to permit generalizations on average thickness and uranium content. A plausible explanation for the higher uranium content here is that the indicated trend on the Eastern Highland Rim of a slight eastward enrichening has continued under the Cumberland Plateau where the shale is too deep for easy sampling. It may well be that organic matter in the eastern part of the sea had the first chance to acquire uranium that was being contributed from the southern Appalachian area.

The uranium content of the shale in Alabama and
Georgia is somewhat lower (Glover, 1959, p. 149-153) than that in the Eastern Highland Rim and Sequatchie Valley areas of Tennessee, but again, data are too scant and the thicknesses of the shale too irregular to permit reliable generalizations as to the probable reason.

\section{TONNAGE}

The black shale of the Gassaway member weighs about 145 pounds per cubic foot, which is equivalent to a specific gravity of about 2.3 ; from this fact and from the uranium analyses it is calculated that shale 1 foot thick having 0.006 percent uranium contains about 120 tons of metallic uranium per square mile. Where the Gassaway has an average thickness of 15 feet, the uranium content is about 1,800 tons per square mile. On the basis of the 1953 drilling, Kehn (1955, p. 26-27) calculated that in the Youngs Bend drilling area the Gassaway member in 21.3 square miles contains about 38,000 tons of uranium. The 500 square miles along the Eastern Highland Rim, where drill cores have shown that shale of similar thickness and grade extends at least 10 miles eastward from the edge of the basin, probably contains about 900,000 tons of uranium. Although this tonnage must be classed as inferred, because of the 10 to 15 mile spacing of data, the known uniformity of the shale over large areas permits these estimates to be made with considerable confidence. In nearly all this area the shale is within 200 feet of the surface.

As 3 of the core holes, field localities YB-46, YB-50, and LC-113A (fig. 16), and numerous oil test wells have consistently penetrated the shale in areas farther east, it seems likely that the shale is present almost everywhere between the Eastern Highland Rim and the belt of the folded Appalachians. Available information from widely scattered places, fortified by geologic evidence, indicates that in this area of about 2,500 square miles a comparable thickness of black shale of the Gassaway member contains at least 0.006 percent uranium. If the average thickness of the shale is 15 feet, the total uranium tonnage would be about 4.5 millions tons. In about a third of this area, along the Highland Rim, the overburden is about 200 feet or less, but in most of the remainder it is more than 1,000 feet.

These estimates of metallic uranium in the area where the thickness and grade of the shale are most favorable indicate that the Chattanooga shale of east central Tennessee constitutes an enormous reserve if the time ever comes when material of that grade must be exploited. The calculations do not allow for the losses in mining and processing the shale. 


\section{LOCALITY REGISTER}

Brief descriptions of the outcrops visited in this study and shown on the maps accompanying this report are given in table 13 . Field numbers were originally assigned to localities of samples of the Chattanooga shale that have been studied and reported on by the U.S. Geological Survey and by several other organizations, including Battelle Memorial Institute, Pennsylvania State University, and the University of Tennessee; simplified numbers were assigned to the localities for this and Hass' (1956) reports. The system used in assigning the original numbers is explained on p. 6. Table 14, a correlation of the original field numbers with those used in this report, follows the locality register.

TABLE 13.-Localities of outcrops shown on maps accompanying this report

[Distances are airline except where measurements along roads are specified]

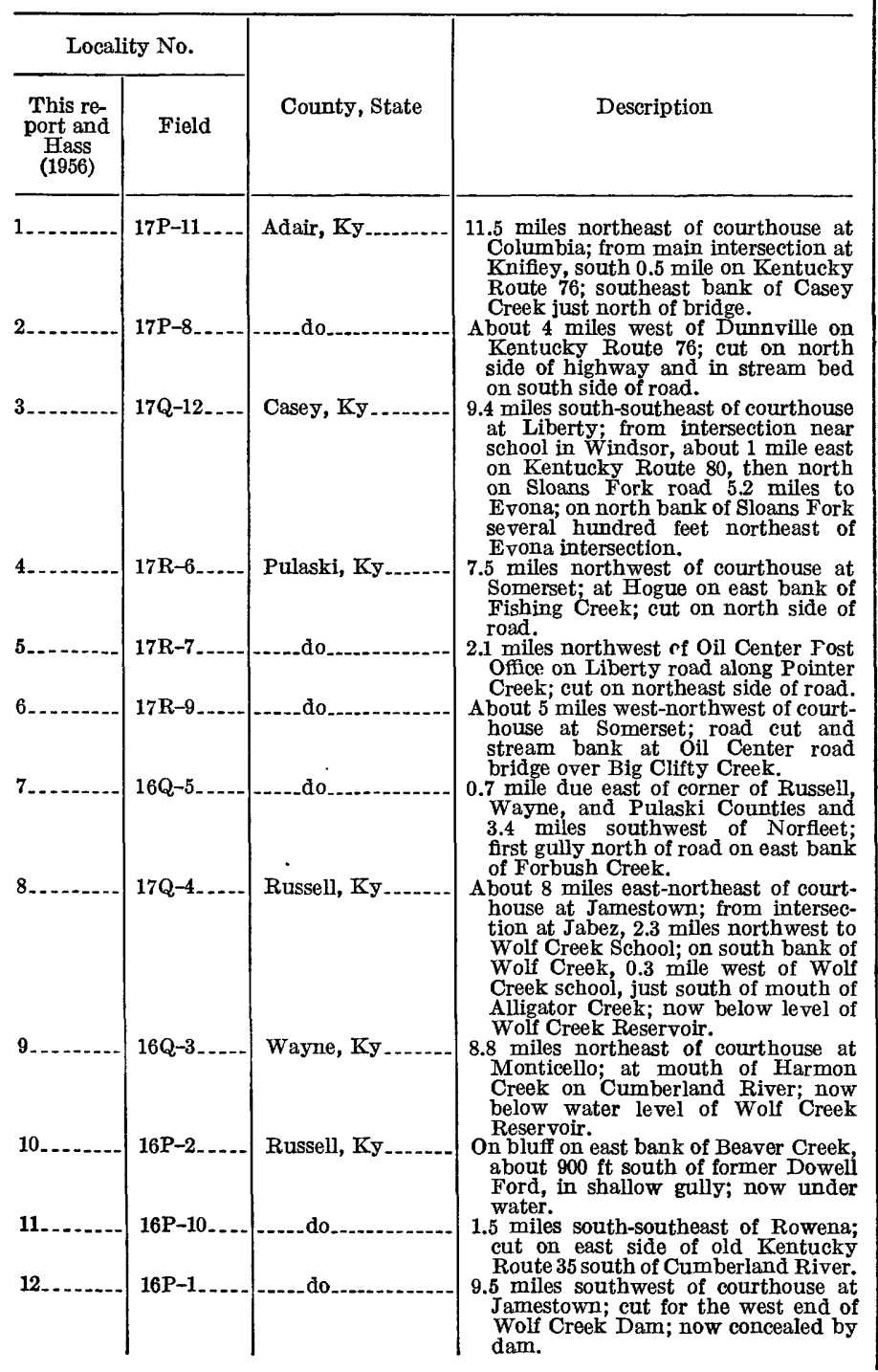

TABLE 13.-Localities of outcrops shown on maps accompanying this report-Continued

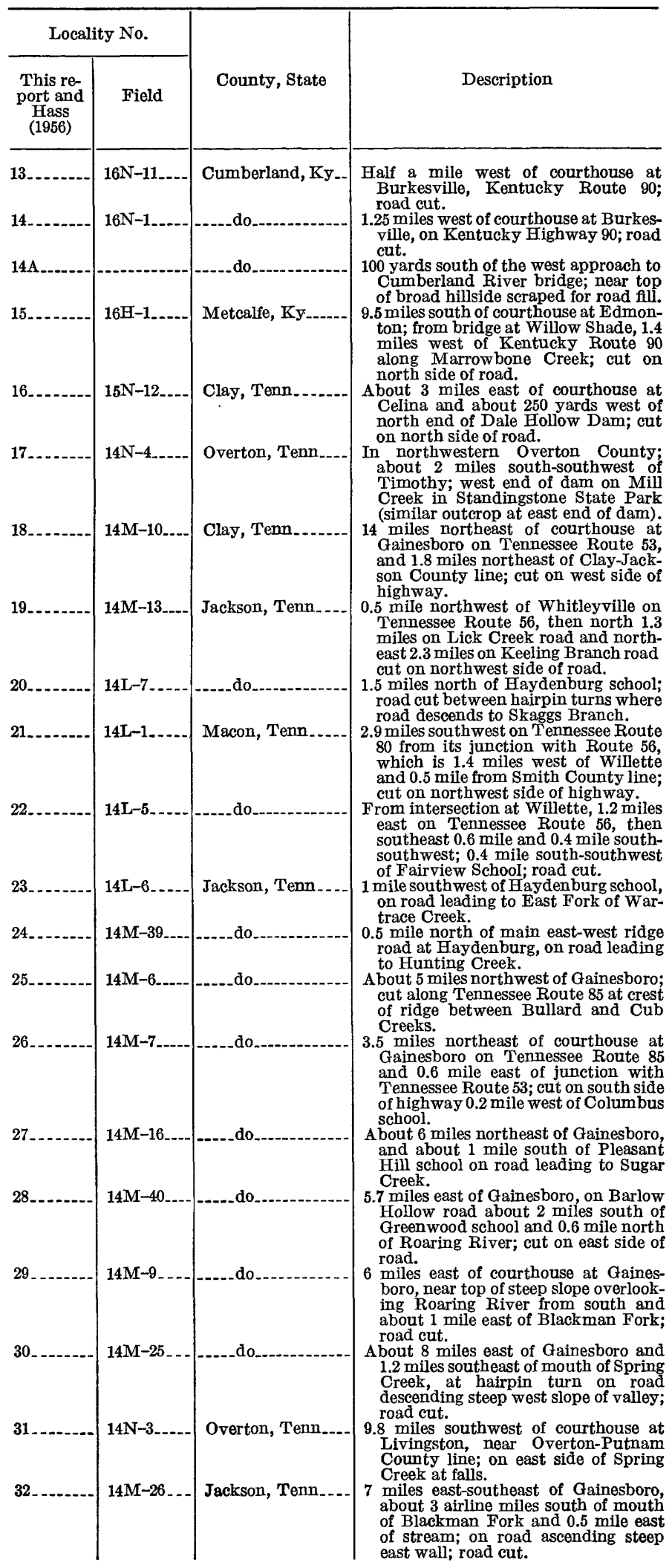


TABLE 13.-Localities of outcrops shown on maps accompanying this report-Continued

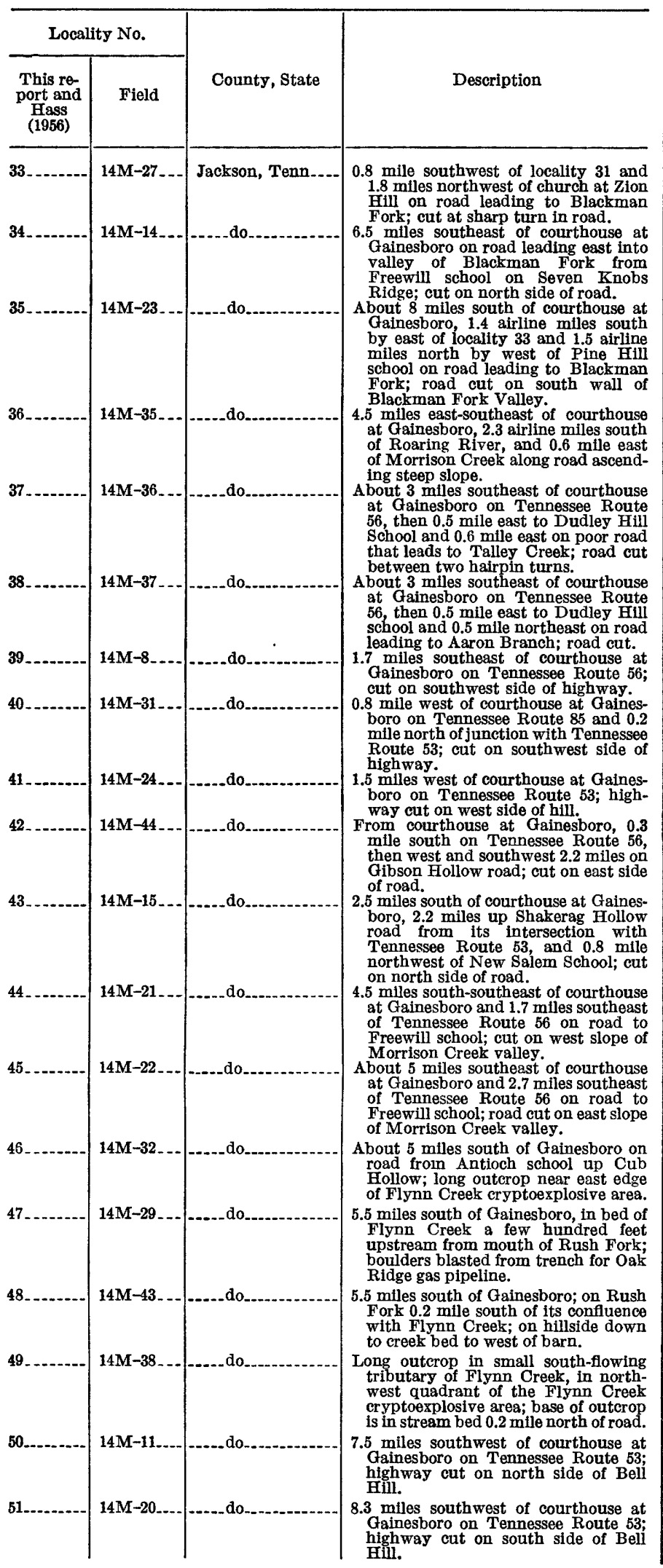

TABLE 13.-Localities of outcrops shown on maps accompanying this report-Continued

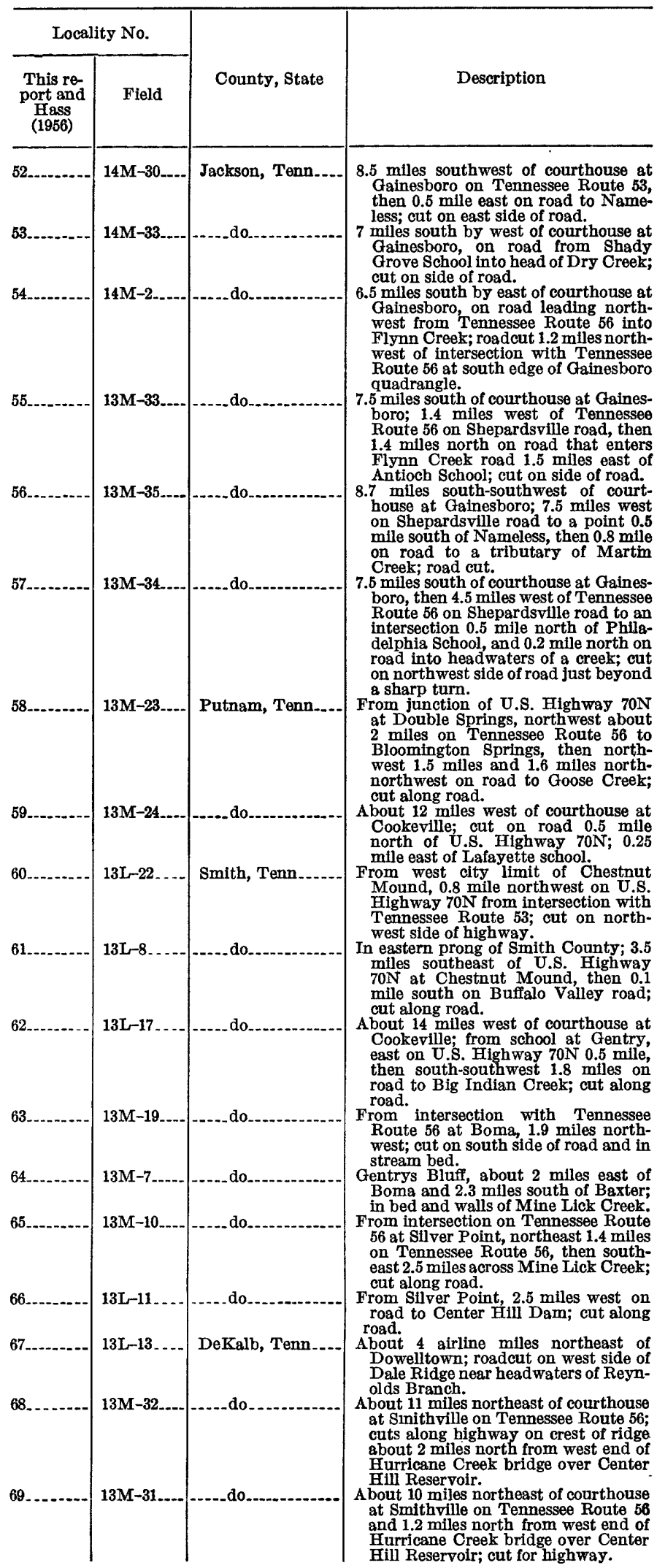


TABLE 13.-Localities of outcrops shown on maps accompanying this report-Continued

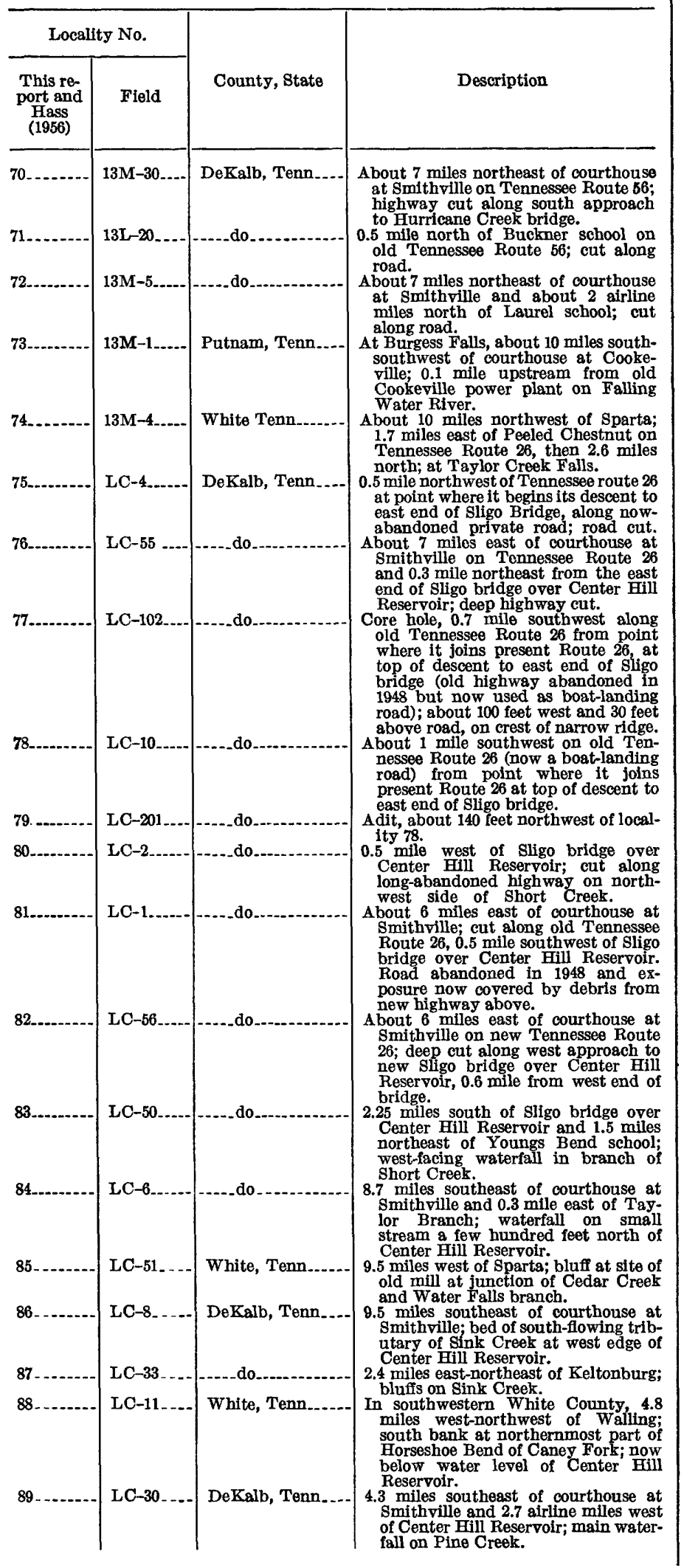

TABLE 13.-Localities of outcrops shown on maps accompanying this report-Continued

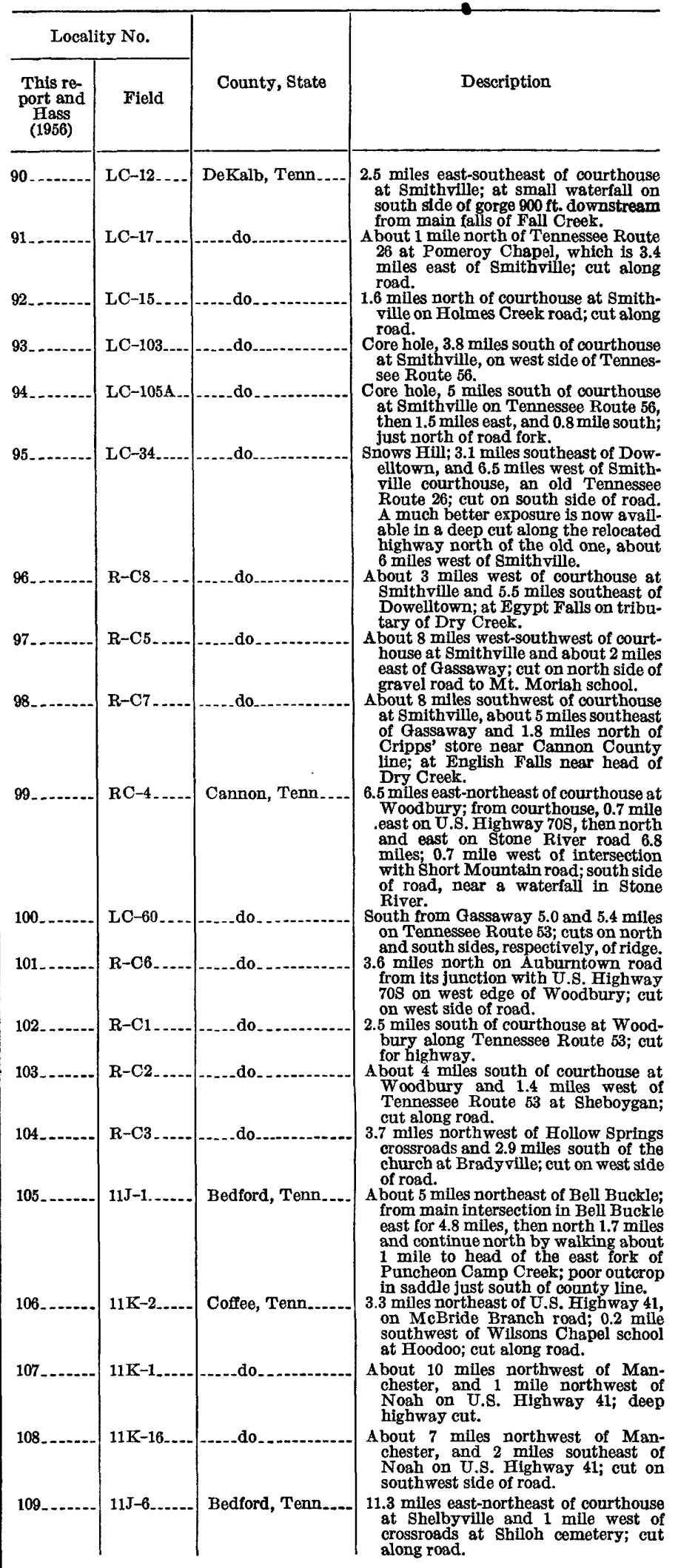


TABLE 13.-Localities of outcrops shown on maps accompanying this report-Continued

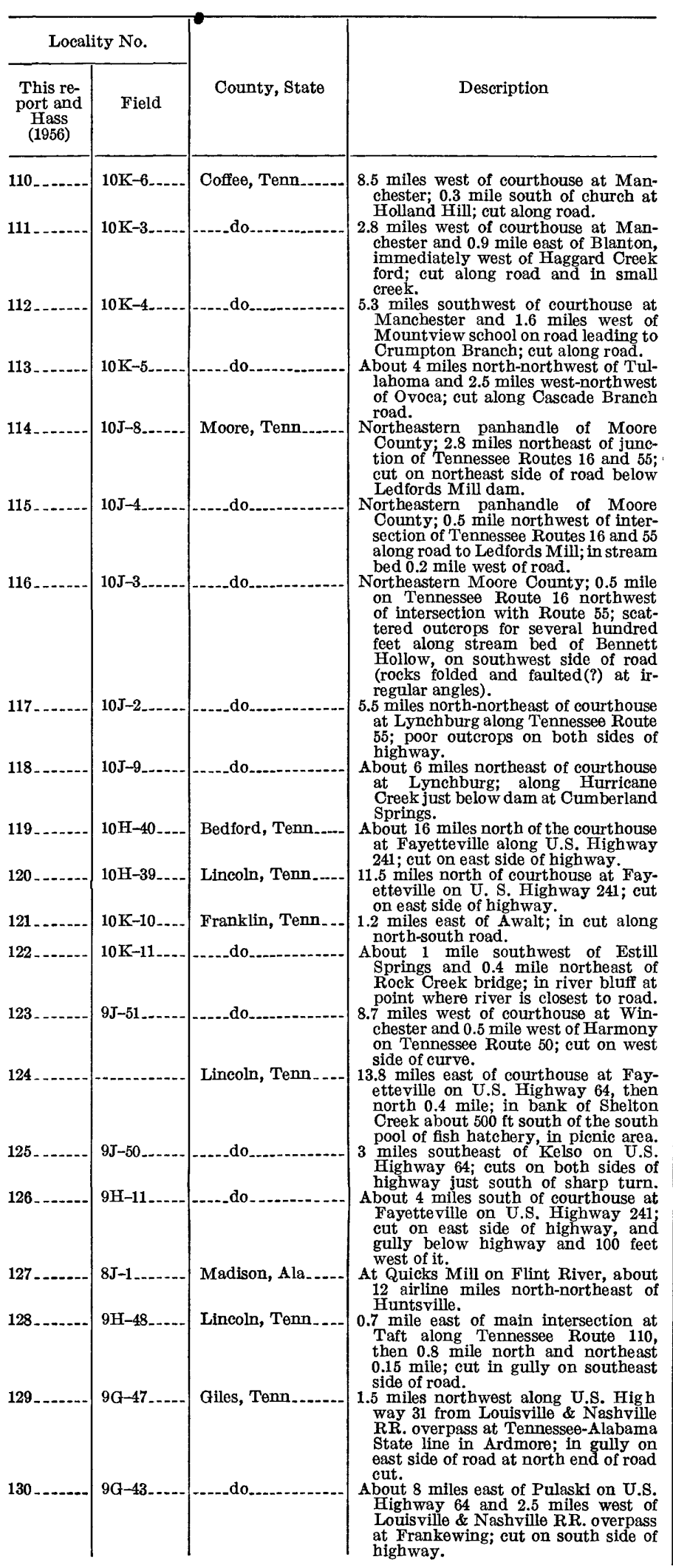

TABLE 13.-Localities of outcrops shown on maps accompanying this report-Continued

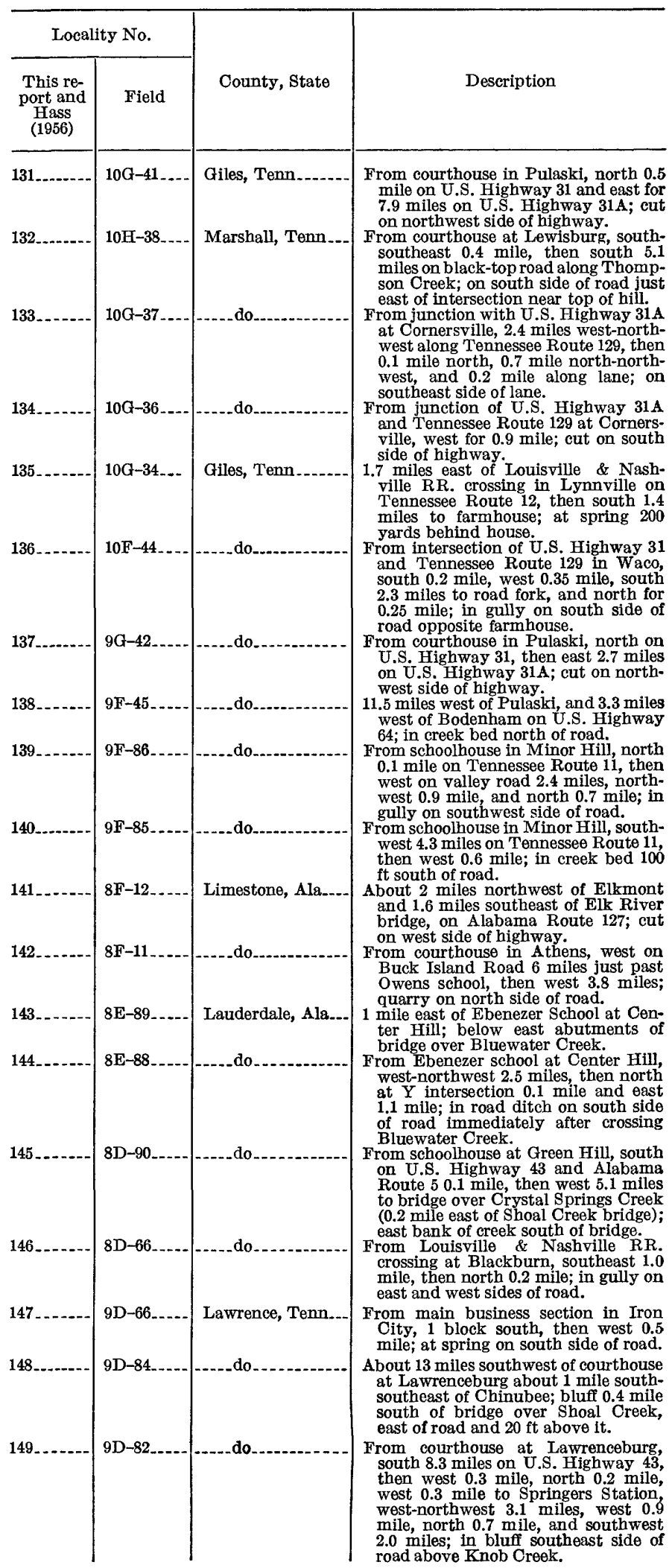


TABLE 13.-Localities of outcrops shown on maps accompanying this report-Continued

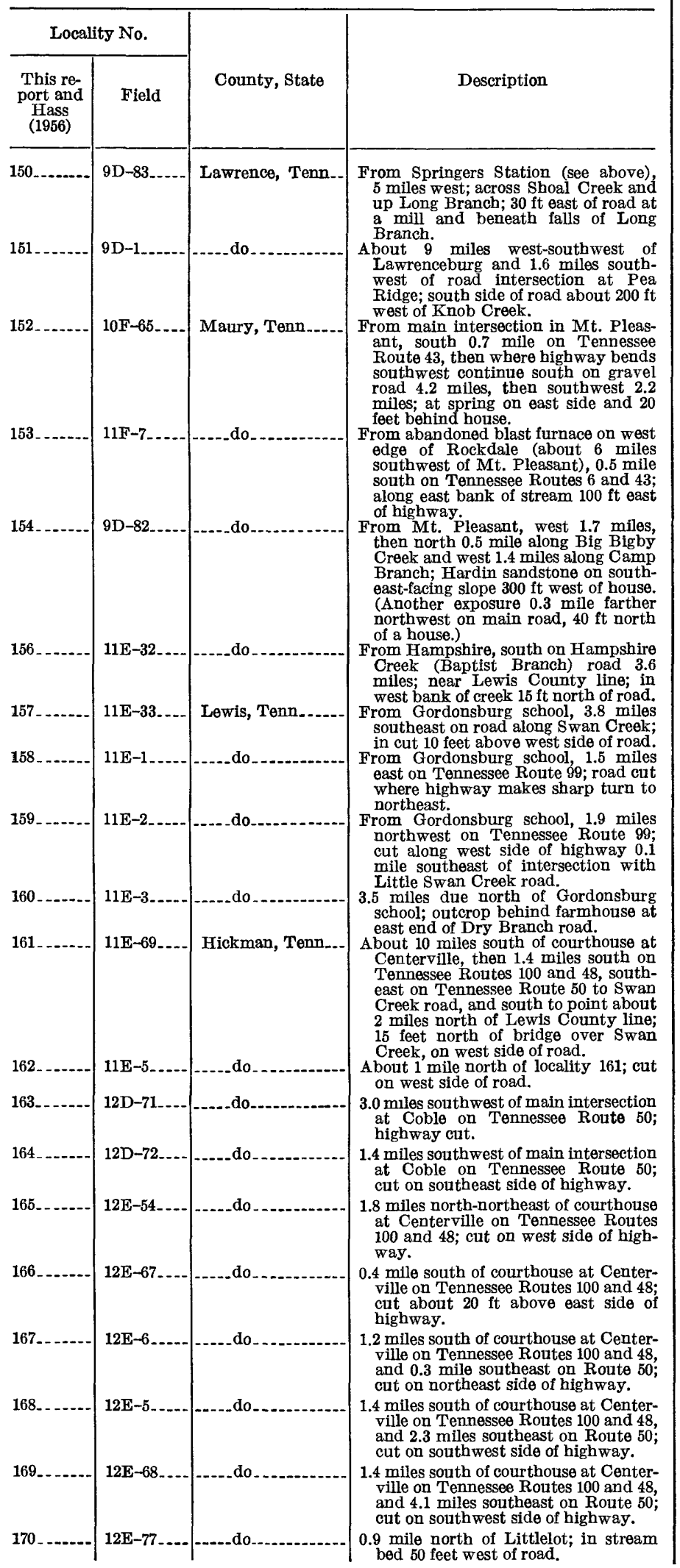

TABLE 13.-Localities of outcrops shown on maps accompanying this report-Continued

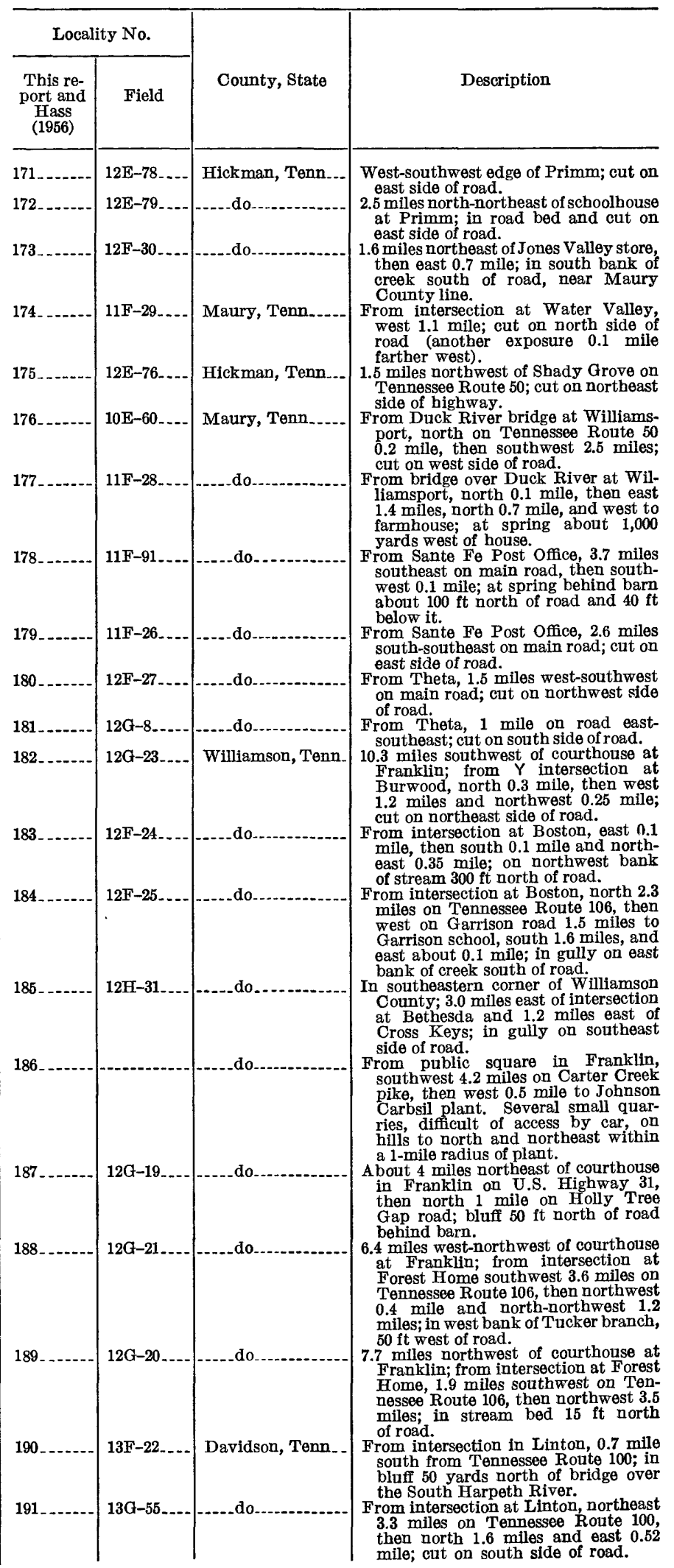


TABLE 13.-Localities of outcrops shown on maps accompanying this report-Continued

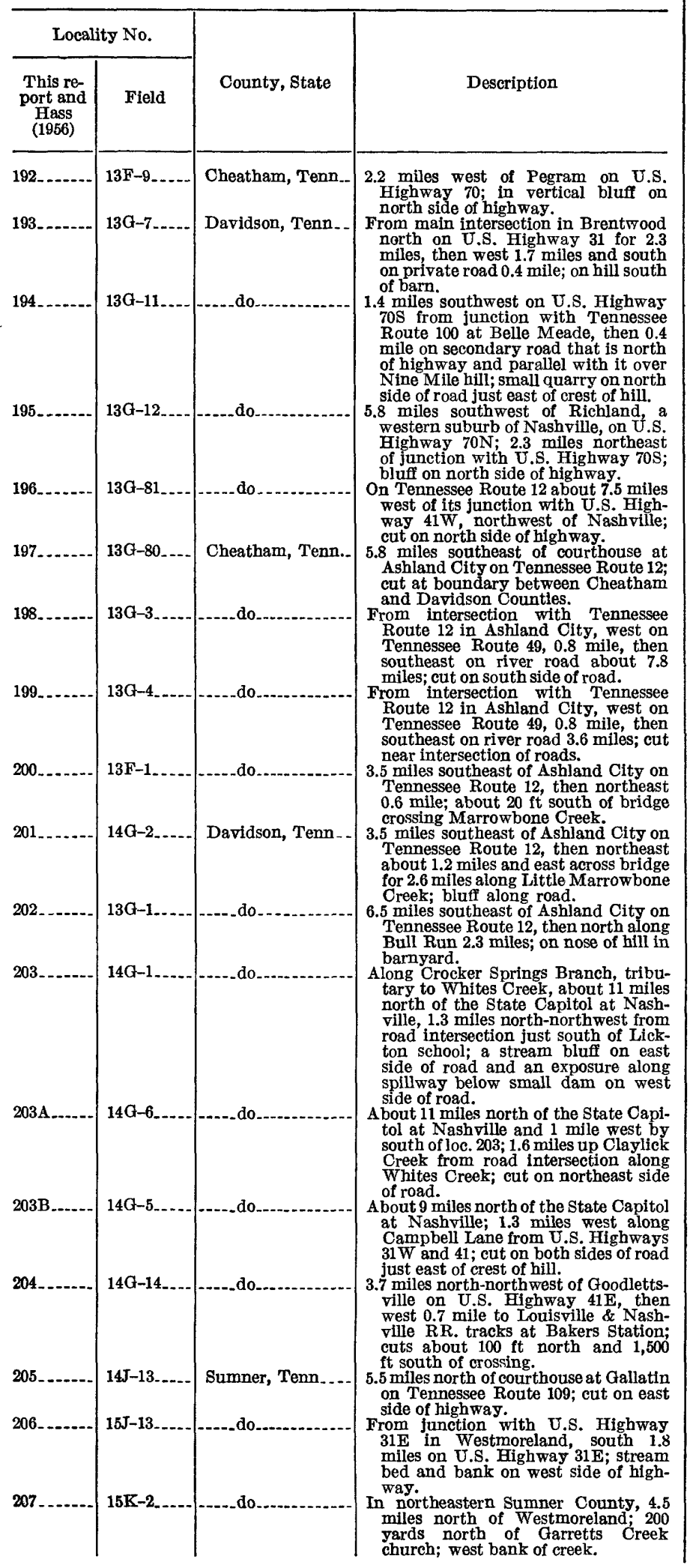

TABLE 13.-Localities of outcrops shown on maps accompanying this report-Continued

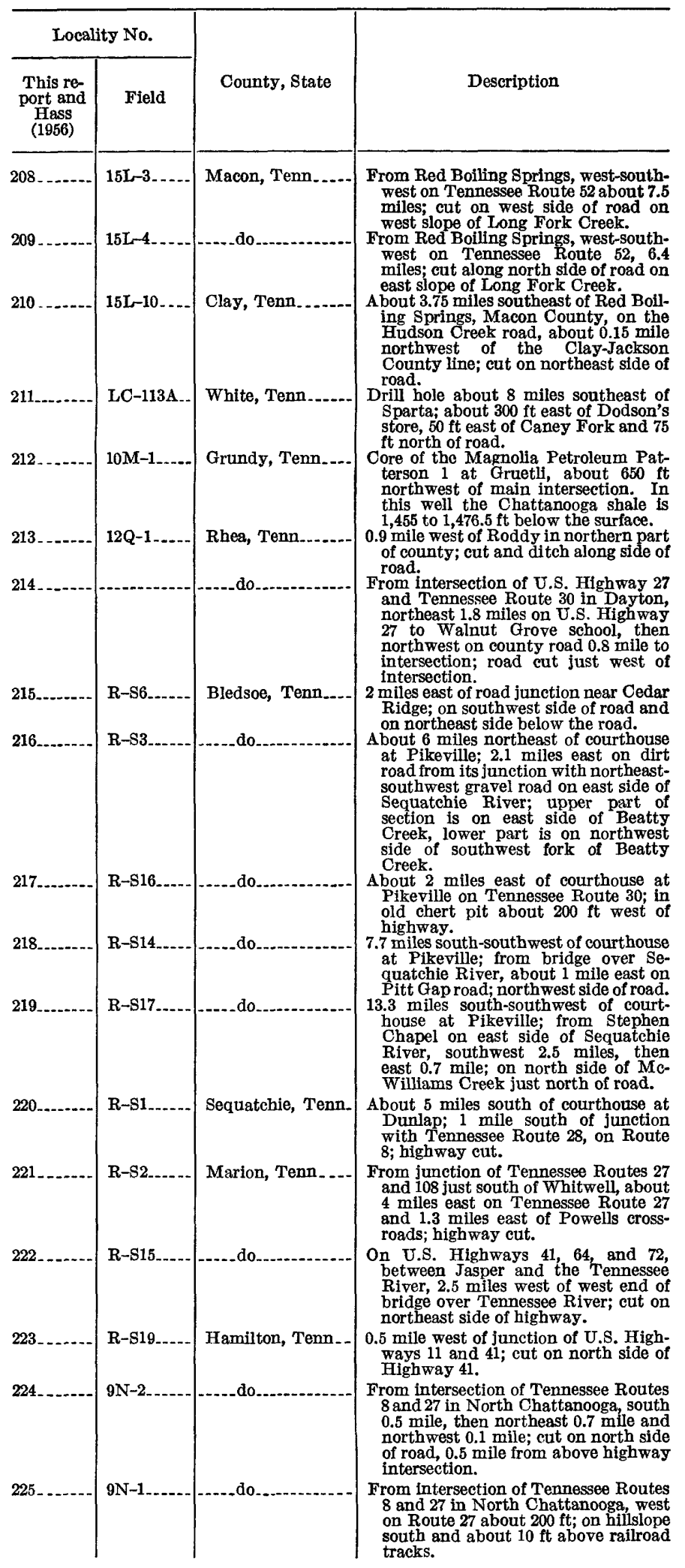


TABLE 13.-Localities of outcrops shown on maps accompanying this report-Continued

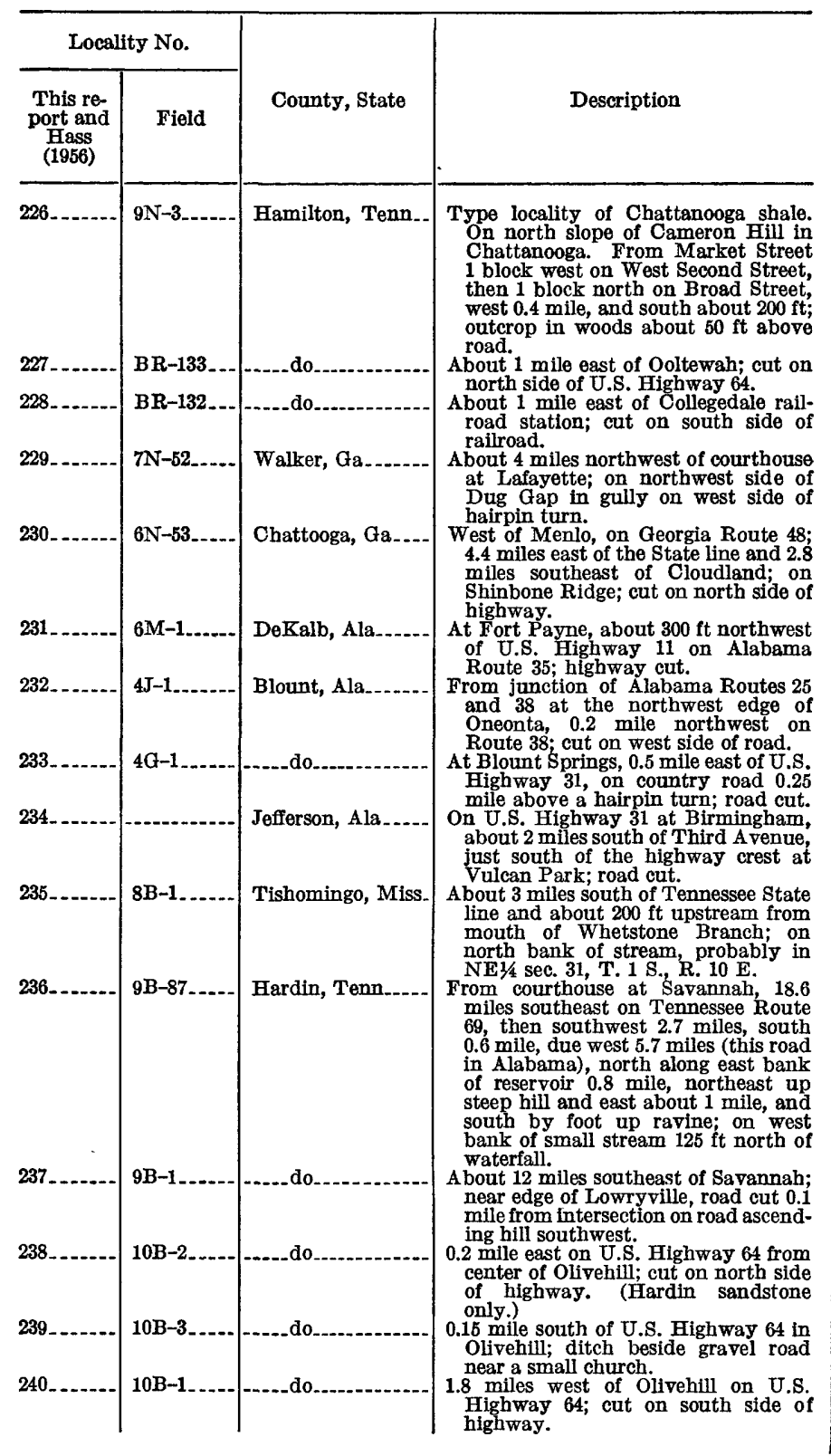

TABLE 13.-Localities of outcrops shown on maps accompanying this report-Continued

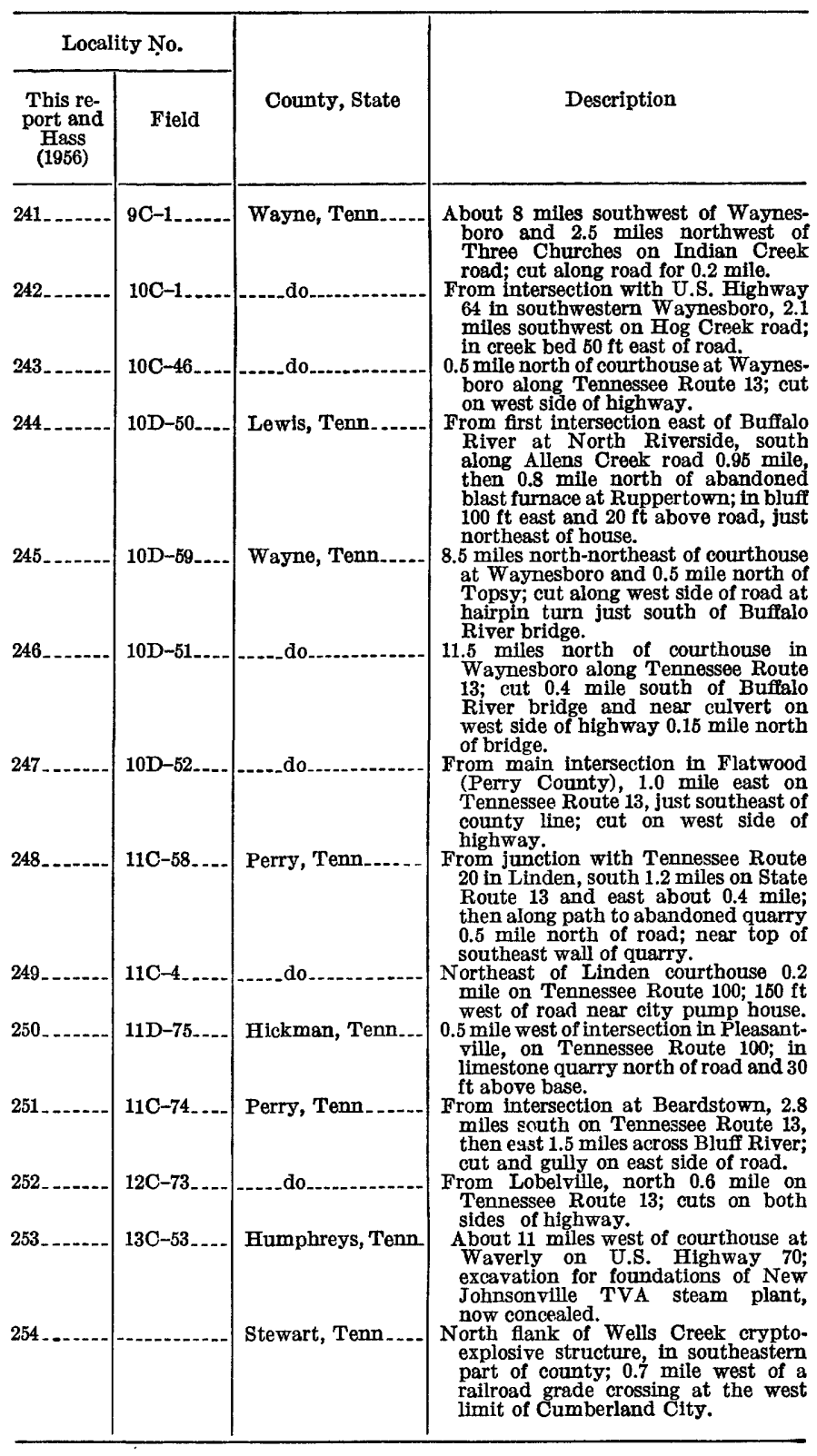




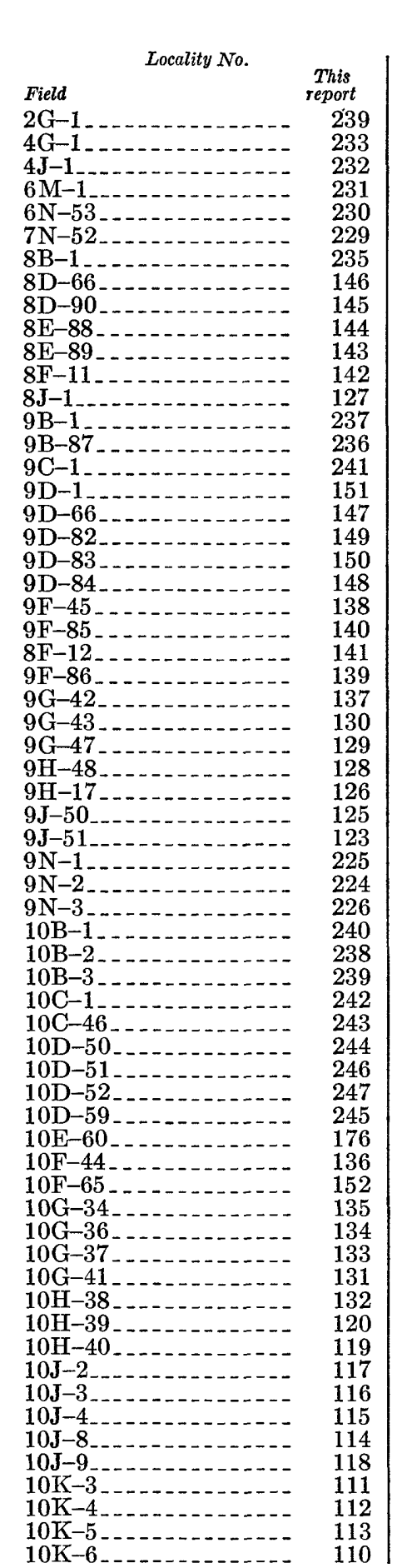

TABLE 14.-Correlation of locality numbers

Locality No. Locality No.

\begin{tabular}{|c|c|c|c|c|c|}
\hline \multicolumn{2}{|l|}{ Locality No. } & \multicolumn{2}{|l|}{ Locality No. } & \multicolumn{2}{|l|}{ Locality No. } \\
\hline Localnty No. & $\begin{array}{c}\text { This } \\
\text { report }\end{array}$ & Localtry No. & $\begin{array}{l}\text { This } \\
\text { report }\end{array}$ & Locauty ivo. & $\begin{array}{c}\text { This } \\
\text { report }\end{array}$ \\
\hline $10 \mathrm{~K}-10$ & 121 & $13 \mathrm{~L}-17$ & 62 & $15 \mathrm{~K}-2$ & 207 \\
\hline $10 \mathrm{~K}-11$ & 122 & $13 \mathrm{~L}-20$ & $7 \overline{1}$ & $15 \mathrm{~L}-3$ & 208 \\
\hline $10 \mathrm{M}-1$ & 212 & $13 \mathrm{~L}-22$ & 60 & $15 \mathrm{~L}-4$ & 209 \\
\hline $11 \mathrm{C}-4$ & 249 & $13 \mathrm{M}-1$ & 73 & $15 \mathrm{~L}-10$ & 210 \\
\hline $11 \mathrm{C}-58$ & 248 & $13 \mathrm{M}-4$ & 74 & $15 \mathrm{~N}-12$ & 16 \\
\hline $11 \mathrm{C}-74_{-}$ & 251 & $13 \mathrm{M}-5_{-}$ & 72 & $16 \mathrm{H}-1$ & 15 \\
\hline-75 & 250 & $13 \mathrm{M}-7$ & 64 & $16 \mathrm{~N}-1$ & 14 \\
\hline $11 \mathrm{E}-1$ & 158 & $13 \mathrm{M}-10$ & 65 & $16 \mathrm{~N}-11$ & 13 \\
\hline $11 \mathrm{E}-2$ & 159 & $13 \mathrm{M}-19$ & 63 & $16 \mathrm{P}-1$ & 12 \\
\hline $11 \mathrm{E}-3 \ldots$ & 160 & $13 \mathrm{M}-23$ & 58 & $16 \mathrm{P}-10$ & 11 \\
\hline $1 \mathrm{E}-5 .-$ & 162 & $13 \mathrm{M}-24$ & 59 & $16 \mathrm{P}-2$ & 10 \\
\hline $11 \mathrm{E}-32$ & 156 & $13 \mathrm{M}-30$ & 70 & $16 Q-3$ & 9 \\
\hline 33 & 157 & $13 \mathrm{M}-31$ & 69 & $16 Q-5$ & 7 \\
\hline $11 \mathrm{E}-69$ & 161 & $13 \mathrm{M}-32$ & 68 & $17 \mathrm{P}-8$ & 2 \\
\hline $11 \mathrm{~F}$ & 153 & $13 \mathrm{M}-33$ & 55 & $17 \mathrm{P}-11$ & 1 \\
\hline $11 \mathrm{~F}-26_{-}$ & 179 & $13 \mathrm{M}-34$ & 57 & $17 \mathrm{Q}-4$ & 8 \\
\hline$-28 \ldots$ & 177 & $13 \mathrm{M}-35$ & 56 & $17 \mathrm{Q}-12$ & 3 \\
\hline $11 F-29$ & 174 & $14 \mathrm{D}$ & 254 & $17 \mathrm{R}-6$ & 4 \\
\hline $1 \mathrm{~F}-91$ & 178 & $14 \mathrm{G}-1 \ldots$ & 203 & $17 \mathrm{R}-7$ & 5 \\
\hline $11 \mathrm{~J}-1$ & 105 & $14 \mathrm{G}-2$ & 201 & $17 \mathrm{R}-9$ & 6 \\
\hline 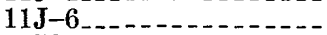 & 109 & $G-5 \ldots$ & $203 \mathrm{~B}$ & $\mathrm{BR}-132$ & 228 \\
\hline $11 \mathrm{~K}-1$ & 107 & $14 \mathrm{G}-6$ & $203 \mathrm{~A}$ & BR-133. & 227 \\
\hline & 106 & $14 \mathrm{G}-14$ & 204 & LC-1 _. & 81 \\
\hline $11 K-16 \ldots$ & 108 & $14 \mathrm{~J}-13$ & 205 & $\mathrm{LC}-2 \ldots$ & 80 \\
\hline $12 \mathrm{C}-73$ & 252 & $14 \mathrm{~L}-1$ & 21 & LC-4... & 75 \\
\hline $12 \mathrm{D}-71$ & 163 & $14 \mathrm{~L}-5$ & 22 & $\mathrm{LC}-6$ & 84 \\
\hline-72 & 164 & $14 \mathrm{~L}-6$ & 23 & LC-8 & 86 \\
\hline $5 \ldots$ & 168 & $14 \mathrm{~L}-7$ & 20 & -10 & 78 \\
\hline $2 \mathrm{E}-6$ & 167 & $14 \mathrm{M}-2$ & 54 & LC-11.. & 88 \\
\hline 54 & 165 & -6 & 25 & $-12 \ldots$ & 90 \\
\hline $12 \mathrm{E}-67$ & 166 & $14 \mathrm{M}-7$ & 26 & LC-15 & 92 \\
\hline 68 & 169 & 8 & 39 & 17 & $9 \overline{1}$ \\
\hline $12 \mathrm{E}-76$ & 175 & $14 \mathrm{M}-9_{\ldots}$ & 29 & LC-30_- & 89 \\
\hline 77 & 170 & $-10 \ldots$ & 18 & $33 \ldots$ & 87 \\
\hline $12 \mathrm{E}-78$ & 171 & $14 \mathrm{M}-11$ & 50 & LC-34 _ - & 95 \\
\hline $12 \mathrm{E}-79$ & 172 & -13 & 19 & $50 \ldots$ & 83 \\
\hline $12 \mathrm{~F}-24 \ldots$ & 183 & $14 \mathrm{M}-14$ & 34 & LC-51_.. & 85 \\
\hline $25 \ldots$ & 184 & $15 \ldots$ & 43 & & 76 \\
\hline $12 \mathrm{~F}-27$ & 180 & $14 \mathrm{M}-16$ & 27 & $\mathrm{LC}-56_{-}$ & 82 \\
\hline $12 \mathrm{~F}-30$ & 173 & & 51 & & 100 \\
\hline $12 \mathrm{G}-8$ & 181 & -21 & 44 & LC-102 & 77 \\
\hline 12 & 187 & & 45 & & 93 \\
\hline $12 \mathrm{G}-20$ & 189 & $14 \mathrm{M}-23$ & 35 & LC-105A & 94 \\
\hline 120 & 18 & & 41 & & 211 \\
\hline-23 & 182 & -25 & 30 & $-201 \ldots$ & 79 \\
\hline-31 . & 185 & & 32 & & 102 \\
\hline 126 & 213 & $14 \mathrm{M}-27_{--}$ & 33 & $\mathrm{C} 2$ & 103 \\
\hline 53 & 25 & & 47 & & 104 \\
\hline $13 \mathrm{~F}-1$ & 200 & -30 & 52 & & 99 \\
\hline & 192 & $\ldots \ldots$ & 40 & C5 & 97 \\
\hline $13 F-22$ & 190 & $14 \mathrm{I}$ & 46 & & 101 \\
\hline & 202 & - & 53 & $\mathrm{C} 7$. & 98 \\
\hline$-3 \ldots$ & 198 & 35 & 36 & & 96 \\
\hline $4 \ldots$ & 199 & 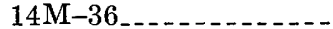 & 37 & $\mathrm{R}-\mathrm{S} 1 \ldots$ & 220 \\
\hline$-7 \ldots$ & 193 & & 38 & & 221 \\
\hline$-11 \ldots \ldots$ & 194 & {$[-38 \ldots \ldots \ldots$} & 49 & $\mathrm{R}-\mathrm{S} 3 \ldots$ & 216 \\
\hline $\mathrm{G}-12$ & 195 & -39 & 24 & $\mathrm{R}-\mathrm{s}$ & 215 \\
\hline$-55 \ldots \ldots \ldots$ & 191 & $\ldots \ldots \ldots$ & 28 & $\mathrm{R}-\mathrm{S} 14$ & 218 \\
\hline & 197 & $-43 \ldots$ & 48 & & 222 \\
\hline $13 \mathrm{G}-81$ & 196 & $\mathrm{I}-44$ & 42 & $\mathrm{R}-\mathrm{S} 16 \ldots$ & 217 \\
\hline & 61 & & 31 & & 219 \\
\hline $13 \mathrm{~L}-11$ & 66 & $14 \mathrm{~N}-4$ & 17 & $\mathrm{R}-\mathrm{S} 19$ & 223 \\
\hline $13 \mathrm{~L}-13 \ldots$ & 67 & $15 \mathrm{~J}-13 \ldots \ldots \ldots$ & 206 & Dayton & 214 \\
\hline
\end{tabular}




\section{SELECTED REFERENCES}

Adams, G. D., 1904, Zinc and lead deposits of northern Arkansas : U. S. Geol. Survey Prof. Paper 24.

Andrews, E. B., 1870, Ohio Geological Survey progress report, 1869 : p. 62.

Androssow, N., 1897, La Mer Noire: Guide des Excursions du VII Congress Geol. Internatl., v. 29.

Bain, H. F., 1895, Central Iowa section of the Mississippian series: Am. Geol., v. 15, p. 317-325.

Bassler, R. S., 1911, The Waverlyan period of Tennessee: U. S. Natl. Mus. Proc., v. 41, p. 209-224.

-1932, The stratigraphy of the Central Basin of Tennessee: Tennessee Div. Geology Bull. 38.

Bates, T. F., 1953, Mineralogy of the Chattanooga shale [abs.] : Geol. Soc. America Bull., v. 64, p. 1529.

Bates, T. F., and Strahl, E. O., 1957, Mineralogy, petrography, and radioactivity of representative samples of Chattanooga shale: Geol. Soc. America Bull., v. 68, p. 1305-1313.

Bates, T. F., Strahl, E. O., Short, N. M., Silverman, E. N., and Camilli, Elena, 1954, Mineralogy and petrography of the Chattanooga shale [abs.] : Geol. Soc. America Bull., v. 65, p. 1230.

Bates, T. F., Wright, H. D., Camilli, Elena, and others, 1953, An investigation of the mineralogy, petrography, and paleobotany of uranium-bearing black shales and lignites. Scope A-shales: U. S. Atomic Energy Comm. NYO 3363, 41 p.

Beers, R. F., 1945, Radioactivity and organic content of some Paleozoic shales: Am. Assoc. Petroleum Geologists Bull., v. 29, p. 1-22.

Beers, R. F., and Goodman, Clark, 1944, Distribution of radioactivity in ancient sediments: Geol. Soc. America Bull., v. 55, p. 1229-1253.

Billings, M. P., 1955, Geologic map of New Hampshire: U. S. Geol. Survey.

Boon, J. D., and Albritton, C. C., Jr., 1938a, Established and supposed examples of meteoritic craters and structures: Field Lab., v. 6, p. 44-56.

- 1938 , The impact of large meteorites: Field Lab., v. 6, p. 57-64.

Borden, W. W., 1874, Report of a geological survey of Clark and Floyd Counties, Indiana: Indiana Geol. Survey 5th Ann. Rept., p. 134-189.

Born, K. E., and Burwell, H. B., 1939, Geology and petroleum resources of Clay County, Tennessee: Tennessee Div. Geology Bull. 47.

Born, K. E., and Wilson, C. W., Jr., 1939, The Howell structure, Lincoln County, Tennessee: Jour. Geology, v. 47, p. 371-388.

Bradley, W. H., 1929, The varves and climate of the Green River epoch : U. S. Geol. Survey Prof. Paper 158-E, p. 87-110.

Branca, W., and Fraas, Eberhard, 1905, Das kryptovulkanische Becken von Steinheim : Berlin, K. Preuss. Akad. Wiss. Abh., p. 1-64.

Breger, I. A., and Deul, Maurice, 1956, The organic geochemistry of uranium, in Page, L. R., Stocking, H. E., and Smith, H. B., compilers, Contributions to the geology of uranium and thorium by the United States Geological Survey and Atomic Energy Commission for the United Nations International Conference on Peaceful Uses of Atomic Energy, Geneva, Switzerland, 1955: U. S. Geol. Survey Prof. Paper 300, p. 505-510.

Breger, I. A., Meyrowitz, .Robert, and Deul, Maurice, 1954, Effects of destructive distillation on the uranium associated with selected naturally occurring carbonaceous substances: Science, new ser., v. 120, p. 310-312.
Breger, I. A., and Schopf, J. M., 1955, Germanium and uranium in coalified wood from Upper Devonian black shale: Geochim. et Cosmochim. Acta, v. 7, p. 287-293.

Bucher, W. H., 1936, Cryptovolcanic structures in the United States : Internat. Geol. Cong., 16th, 1933, Rept., v. 2, p. 10551084.

Butts, Charles, 1911, Description of the Birmingham quadrangle [Alabama]: Field ed., U. S. Geol. Survey Geol. Atlas Folio 175.

-1919, Geology and oil possibilities of the northern part of Overton County, Tennessee, and of adjoining parts of Clay, Pickett, and Fentress Counties: Tennessee Div. Geology Bull. 24, Ann. Rept. 1919, pt. 2-A.

Campbell, Guy, 1946, New Albany shale: Geol. Soc. America Bull., v. 57, p. 829-908.

Cayeux, Lucien, 1897, Contribution à l'étude micrographique des terrains sédimentaires: Mém. Soc. Géol. Nord., v. 26, pt. 2, p. 168-187.

Clarke, F. W., 1924, The data of geochemistry: 5th ed., U. S. Geol. Survey Bull. 770.

Clarke, J. M., 1885, On the higher Devonian faunas of Ontario County, New York: U. S. Geol. Survey Bull. 16.

-1904, Naples fauna in western New York: New York State Mus. Mem. 6, p. 199-454.

Cline, L. M., 1934, Osage formations of southern Ozark region, Missouri, Arkansas, and Oklahoma : Am. Assoc. Petroleum Geologists Bull., v. 18, p. 1132-1159.

Cloud, P. E., 1955, Physical limits of glauconite formation: Am. Assoc. Petroleum Geologists Bull., v. 39, p. 484-492.

Conrad, S. G., Elmore, R. T., Jr., and Maher, S. W., 1954, Stratigraphy of the Chattanooga black shale in the Flynn Creek structure, Jackson County, Tennessee [abs.] : Geol. Soc. America Bull., v. 65, p. 1358.

1957, Stratigraphy of the Chattanooga black shale in the Flynn Creek structure, Jackson County, Tennessee: Tennessee Acad. Sci., Jour., v. 32, No. 1, p. 9-18.

Cooper, C. L., 1948, in Weller, J. M., chairman, Correlation of the Mississippian formations of North America: Geol. Soc. America Bull., v. 59, p. 91-196.

Cooper, G. A., and others, 1942, Correlation of the Devonian sedimentary formations of North America: Geol. Soc. America Bull., v. 53, chart 4, p. 1729-1793.

-1957, Paleoecology of Middle Devonian eastern and central United States, in Ladd H. S. ed., Paleoecology, v. 2 of Treatise on marine ecology and paleoecology: Geol. Soc. America Mem. 67, p. 249-277.

Crouse, C. S., 1925, An economic study of the black Devonian shales of Kentucky, in Thiessen, Reinhardt, and others, Oil shales of Kentucky: Kentucky Geol. Survey, ser. 6, v. 21, p. 59-97.

Cuttitta, Frank, 1953, A photometric method for the estimation of the oil yield of oil shale, in Brannock, W. W., and others, Contributions to geochemistry, 1949 : U. S. Geological Survey Bull. 992, pt. 2, p. 15-31.

Dawson, J. W., 1876, Note on the phosphate of the Laurentian and Cambrian rocks of Canada: Geol. Soc. London Quart. Jour., v. 32, p. 285-291.

Deul, Maurice, 1957, Geochemistry of uranium-bearing shale, in Geologic investigations of radioactive deposits-Semiannual progress report, June 1-Nov. 30, 1957: U. S. Geol. Survey Trace Elements Memo. Repts., p. 213-224.

Dietz, R. S., 1946, Geological structures possibly related to Iunar craters: Pop. Astronomy, v. 54, p. 465-467. 
Dietz, R. S., Emery, K. O., and Shepard, F. P., 1942, Phasphorite deposits on the sea fioor off southern California: Geol. Soc. America Bull., v. 53, p. 815-847.

Dietz, R. S., and Menard, H. W., 1951, Origin of abrupt change in slope at continental shelf margin: Am. Assoc. Petroleum Geologists Bull., v. 35, p. 1994-2016.

Dunbar, C. O., 1919, Stratigraphy and correlation of the Devonian of western Tennessee: Tennessee Geol. Survey Bull. 21.

Edwards, Ira, and Rassche, Gilbert, 1922, Notes on the occurrence of Upper Devonian strata in Wisconsin: Public Museum of City of Milwaukee Yearbook, 1921, v. 1, p. 88-93.

Ellison, S. P., Jr., 1946, Conodonts as Paleozoic guide fossils: Am. Assoc. Petroleum Geologists Bull., v. 30, p. 93-110.

Fenneman, N. M., 1938, Physiography of eastern United States: New York, McGraw-Hill Book Co.

Fettke, C. R., 1952, Tioga bentonite in Pennsylvania and adjacent States: Am. Assoc. Petroleum Geologists Bull., v. 36, p. 2038-2040.

Flowers, R. R., 1952, Lower Middle Devonian metabentonite in West Virginia: Am. Assoc. Petroleum Geologists Bull., v. 36, p. 2036-2038.

Foerste, A. F., 1901, Silurian and Devonian limestones of Tennessee and Kentucky: Geol. Soc. America Bull., v. 12, p. $395-444$.

Freeman, L. B., 1951, Regional aspects of Silurian and Devonian subsurface stratigraphy in Kentucky: Am. Assoc. Petroleum Geologists Bull., v. 35, p. 1-61. Also published by Kentucky Geological Survey as ser. 9, reprint 2, and as Bull. 6.

Galloway, J. J., 1919, Geology and natural resources of Rutherford County, Tennessee: Tennessee Div. Geology Bull. 22.

Girty, G. H., 1898, Description of a fauna found in the Devonian black shale of eastern Kentucky : Am. Jour. Sci., 4th ser., v. 6, p. 384-395.

Glover, Lynn, 1959, Stratigraphy and uranium content of the Chattanooga shale in northeastern Alabama, northwestern Georgia, and eastern Tennessee: U. S. Geol. Survey Bull. 1087-E, p. 133-168.

Goldman, M. I., 1922, Basal glauconite and phosphate beds: Science, new ser., v. 56, p. 171-173.

-1924, "Black shale" formation in and about Chesapeake Bay : Am. Assoc. Petroleum Geologists Bull., v. 8, p. 195201.

Grabau, A. W., 1906, Types of sedimentary overlap: Geol. Soc. America Bull., v. 17, p. 567-636.

Grabau, A. W., and O'Connell, Marjorie, 1917, Were the graptolite shales, as a rule, deep or shallow water deposits?: Geol. Soc. America Bull., v. 28, p. 959-964.

Hard, E. H., 1931, Black shale deposition in central New York : Am. Assoc. Petroleum Geologists Bull., v. 15, p. 165-181.

Hass, W. H., 1948, Upper Devonian bentonite in Tennessee : Am. Assoc. Petroleum Geologists Bull., v. 32, p. 816-819. 1953, Age of the Chattanooga shale and Maury formation [abs.]: Geol. Soc. Am. Bull., v. 64, p. 1532.

-1956, Age and correlation of the Chattanooga shale and the Maury formation: U. S. Geol. Survey Prof. Paper 286.

Hass, W. H., and Lindberg, M. L., 1946, Orientation of the crystal units of conodonts: Jour. Paleontology, v. 20, p. $501-504$.

Hayes, C. W., 1891, The overthrust faults of the southern Appalachians: Geol. Soc. America Bull., v. 2, p. 141-154.
1892, Report on the geology of northeastern Alabama and adjacent portions of Georgia and Tennessee: Alabama Geol. Survey Bull. 4.

-1894a, Description of the Ringgold quadrangle [GeorgiaTennessee] : U. S. Geol. Survey Geol. Atlas, Folio 2.

$-1894 b$, Description of the Kingston quadrangle [Tennessee] : U. S. Geol. Survey Geol. Atlas, Folio 4.

1894c, Description of the Chattanooga quadrangle [Tennessee] : U. S. Geol. Survey Geol. Atlas, Folio 6.

-1894d, Description of the Sewanee quadrangle [Tennessee] : U. S. Geol. Survey Geol. Atlas, Folio 8.

-1895, Description of the Cleveland quadrangle [Tennessee] : U. S. Geol. Survey Geol. Atlas, Folio 20.

1896, The Tennessee phosphates: U. S. Geol. Survey 17th Ann. Rept., pt. 2, p. 513-550.

-1899, Physiography of the Chattanooga district in Tennessee, Georgia, and Alabama: U. S. Geol. Survey 19th Ann. Rept., pt. 2, p. 1-58.

Hayes, C. W., and Ulrich, E. O., 1903, Description of the Columbia quadrangle [Tennessee] : U. S. Geol. Survey Geol. Atlas, Folio 95.

Hedberg, H. D., 1926, The effect of gravitational compaction on the structure of sedimentary rocks: Am. Assoc. Petroleum Geologists Bull., v. 10, p. 1035-1072.

Hollingsworth, S. E., and Bannister, F. A., 1950, Basaluminite and hydrobasaluminite, two new minerals from Northamptonshire: Mineralog. Mag., v. 29, p. 1-17.

Holmes, G. B., 1928, A bibliography of conodonts with descriptions of early Mississippian species: U. S. Natl. Mus. Proc., v. 72 , art. $5,38 \mathrm{p}$.

Huddle, J. W., 1933, Marine fossils from the top of the New Albany shale of Indiana: Am. Jour. Sci., 5th ser., v. 25, p. 303-314.

Jewell, W. B., 1931, Geology and mineral resources of Hardin County, Tennessee: Tennessee Div. Geology Bull. 37.

Jillson, W. R., 1951a, Geology of Cumberland County, Kentucky : Frankfort, Ky., Roberts Printing Co.

-1951b, The Burkesville limestone: Frankfort, Ky., Robert Printing Co.

Kay, Marshall, 1951, North American geosynclines: Geol. Soc. America Mon. 48, $143 \mathrm{p}$.

Kehn, T. M., 1955, Uranium in the Chattanooga shale, Youngs Bend area, Eastern Highland Rim, Tennessee: U. S. Geol. Survey TEI-528-A, issued by U. S. Atomic Energy Comm. Tech. Inf. Service, Oak Ridge, Tenn.

Keulegan, G. H., and Krumbein, W. C., 1949, Stable configuration of bottom slope in a shallow sea and its bearing on geological processes: Am. Geophys. Union Trans., v. 30, p. 855-861.

Kindle, E. M., 1912, The unconformity at the base of the Chattanooga shale in Kentucky : Am. Jour. Sci., 4th ser., v. 183, p. 120-136.

King, P. B., 1950, Tectonic framework of southeastern United States: Am. Assoc. Petroleum Geologists Bull., v. 34, p. 635-671.

1951, The tectonics of middle North America : Princeton Univ. Press, 220 p.

King, P. B., and others, 1944, Tectonic map of the United States: Am. Assoc. Petroleum Geologists.

Kinney, C. R., Broadhead, R. L., Leonard, J. T., Roessing, T. J., Chen, J. P., and Weinstein, A., 1957, An investigation of the chemical nature of the organic matter of uraniferous shales: U. S. Atomic Energy Comm. NYO-6677, 42 p. 
Kinney, C. R., Leonard, J. T., Chem. J. P., and Weinstein, A., 1958 , An investigation of the chemical nature of the organic matter of uraniferous shale, in Semiannual report covering the period October 1, 1957 to March 31, 1958: U. S. Atomic Energy Comm. NYO-6678.

Klepser, H. J., 1937, The Lower Mississippian rocks of the Eastearn Highland Rim: Ohio State Univ. Abs. Doctoral Dissert., v. 24, p. 181-187.

Koczy, F. H., 1954, Geochemical balance in the hydosphere, in Faul, Henry, ed., Nuclear geology : New York, John Wiley \& Sons, Inc.

Langbein, W. B., and others, 1949, Annual runoff in the United States: U. S. Geol. Survey Circular 52.

Lapworth, Charles 1889, On the Ballantrae rocks of south Scotland and their place in the upland sequence: Geol. Mag., new ser., December 3, v. 6, p. 20-24, 59-69.

Lucke, J. B., 1935, Bottom conditions in a tidal lagoon: Jour. Paleontology, v. 9, p. 101-107.

Lusk, R. G., 1927, A pre-Chattanooga sink hole: Science, new ser., v. 65, p. 579-580.

Maher, S. W., and Dunkle, D. H., 1955, An occurrence of a pleuropterygian shark in the Chattanooga shale of Tennesee: Tennessee Acad. Sci. Jour., v. 30, p. 202-203.

Marble, J. P., 1950, Report of the Committee on the measurement of geologic time, 1949-1950: Natl. Research Council Div. Geology and Geography, p. 1-24.

Marr, J. E., 1925, The Stockdale shales of the Lake District: Geol. Soc. Quart. Jour., v. 81, pt. 2, p. 113-133.

Mather, K. F., 1920, Oil and gas resources of the northeastern part of Sumner County, Tennessee : Tennessee Div. Geology Bull. 24, Ann. Rept. 1919. pt. 2-B.

McKelvey, V. E., and Nelson, J. M., 1950, Characteristics of marine uranium-bearing sedimentary rocks : Econ. Geology, v. 45, p. 35-53.

Mellen, F. F., 1947, Black Warrior basin, Alabama and Mississippi : Am. Assoc. Petroleum Geologists Bull., v. 31, p. 1801-1816.

-1955, Subsurface outliers of Chattanooga shale in northeastern Mississippi : Am. Assoc. Petroleum Geologists Bull., v. 39, p. 1864-1865.

Milton, Charles, Conant, L. C., and Swanson, V. E., 1955, SubChattanooga residuum in Tennessee and Kentucky: Geol. Soc. America Bull., v. 66, p. 805-810.

Miser, H. D., 1921, Mineral resources of the Waynesboro quadrangle, Tennessee: Tennessee Div. Geology Bull. 26.

Moore, G. W., 1954, Extraction of uranium from aqueous solution by coal and some other materials: Econ. Geology, v. 49 , p. $652-658$.

Moore, R. C., 1929, Environment of Pennsylvanian life in North America : Am. Assoc. Petroleum Geologists Bull., v. 13, p. 459-487.

-1949, Meaning of facies, in Longwell, C. R., and others, Sedimentary facies in geologic history: Geol. Soc. America Mem. 39, p. 1-34.

Morse, W. C., 1930, Paleozoic rocks [of Mississippi] : Mississippi Geol. Survey Bull. 23.

Morse, W. C., and Foerste, A. F., 1909, The Waverly formations of east-central Kentucky: Jour. Geology, v. 17, p. 164-177.

Nelson, W. A., 1913, Mineral products along the Tennessee Central Railroad: Resources Tenn., v. 3, no. 3, p. 137-160.
Pepper, J. F., and deWitt, Wallace, Jr., 1950, Stratigraphy of the Upper Devonian Wiscoy sandstone and the equivalent Hanover shale in western and central New York: U. S. Geol. Survey Oil and Gas Inv. Prelim. Chart 37.

Pettijohn, F. J., 1949, Sedimentary rocks: New York, Harper \& Bros.

Pohl, E. R., 1930, The black shale series of central Tennessee: Am. Jour. Sci., 5th ser., v. 20, p. 151-152.

Price, P. H., and Woodward, H. P., 1940, Résumé of the Devonian system of West Virginia: Am. Assoc. Petroleum Geologists Bull., v. 24, p. 1983-1994.

Rich, J. L., 1948, Probable deep-water origin of the MarcellusOhio-New Albany-Chattanooga black shale [abs.]: Geol. Soc. America Bull., v. 59, p. 1346-1347.

1951a, Three critical environments of deposition and criteria for recognition of rocks deposited in each of them: Geol. Soc. America Bull., v. 62, p. 1-20.

1951b, Probable fondo origin of Marcellus-Ohio-New Albany-Chattanooga bituminous shales: Am. Assoc. Petroleum Geologists Bull., v. 35, p. 2017-2040.

-1953, Paleogeographic implications of evidences pointing to fondo origin of the Chattanooga-New Albany-Ohio bituminous shale [abs.]: Geol. Soc. America Bull., v. 64, p. 1535-1536.

Ross, C. S., 1955, Provenience of pyroclastic materials: Geol. Soc. America Bull., v. 66, p. 427-434.

Rubey, W. W., 1930, Lithologic studies of fine-grained Upper Cretaceous sedimentary rocks of the Black Hills region: U. S. Geol. Survey Prof. Paper 165-A, p. 1-54.

Ruedemann, Rudolf, 1934, Paleozoic plankton of North America : Geol. Soc. America Mem. 2.

Russell, W. L., 1944, The total gamma-ray activity of sedimentary rocks as indicated by Geiger counter determinations: Geophysics, v. 9, p. 180-216.

1945, Relation of radioactivity, organic content, and sedimentation: Am. Assoc. Petroleum Geologists Bull., v. 29, p. 1470-1493.

Safford, J. M., 1851, The Silurian system of middle Tennessee, with notices of the strata surrounding it: Am. Jour. Sci., 2d ser., v. 12, p. 352-361.

-1856, A geological reconnaissance of the State of Tennessee: First biennial report presented to the Thirty-first General Assembly of Tennessee: Nashville, $164 \mathrm{p}$.

1869, Geology of Tennessee: Nashville, $551 \mathrm{p}$.

Safford, J. M., and Killebrew, J. B., 1900, The elements of the geology of Tennessee: Nashville, $246 \mathrm{p}$.

Savage, T. E., 1930, The Devonian rocks of Kentucky : Kentucky Geol. Survey, ser. 6, v. 33.

Savage, T. E., and Sutton, A. H., 1931, Age of the black shale in south-central Kentucky: Am. Jour. Sci., 5th ser., v. 22, p. 441-448.

Schuchert, Charles, 1910, Paleogeography of North America: Geol. Soc. America Bull., v. 20, p. 427-606.

1915, The conditions of black shale deposition as illustrated by the Kupferschiefer and Lias of Germany: Am. Philosophical Soc. Proc. 54, p. 259-269.

Shepard, F. P., 1948, Submarine geology : New York, Harper \& Bros.

Smith, R. W., and Whitlatch, G. I., 1940, The phosphate resources of Tennessee: Tennessee Div. Geology Bull. 48.

Stockdale, P. B., 1939, Lower Mississippian rocks of the eastcentral interior: Geol. Soc. America Spec. Paper 22. 
Strahl, E. O., Camilli, Elena, Short, N. M., and others, 1954, An investigation of the mineralogy, petrography and paleobotany of uranium-bearing shales and lignites. Scope Ashales: U. S. Atomic Energy Comm. NYO-6060, 70 p.

Strahl, E. O., Silverman, E. O., O'Neil, R. L., and others, 1955, An investigation of the mineralogy, petrography, and paleobotany of uranium-bearing shales and lignites. Scope Ashales: U. S. Atomic Energy Comm. NYO-6068, 79 p.

Strom, K. M., 1948, A concentration of uranium in black muds : Nature, v. 162, p. 922.

Sverdrup, H. V., Johnson, M. W., and Fleming, R. H., 1942, The oceans: New York, Prentice-Hall, Inc.

Swartz, J. H., 1924, The age of the Chattanooga shale of Tennessee: Am. Jour. Sci., 5th ser., v. 7, p. 24-30. 1926, The age of the Big Stone Gap shale of southwestern Virginia: Am. Jour. Sci., 5th ser., v. 12, p. 522-531. 1927, The Chattanoogan age of the Big Stone Gap shale: Am. Jour. Sci., 5th ser., v. 14, p. 485-499.

1929, The age and stratigraphy of the Chattanooga shale in northeastern Tennessee and Virginia: Am. Jour. Sci., 5th ser., v. 17, p. 431-448.

Trask, P. D., 1951, Depositional environment of black shale: Program 1951 Ann. Mtg., Am. Assoc. Petroleum Geologists, St. Louis, Mo., April 23-26, p. 44.

Troost, Gerard, 1835, Third geological report to the Twentyfirst General Assembly of the State of Tennessee: Nashville, 32 p.

-1837, Fourth geological report to the Twenty-second General Assembly of the State of Tennessee: Nashville, $37 \mathrm{p}$.

-1840, Fifth geological report to the Twenty-third General Assembly of Tennessee: Nashville, $75 \mathrm{p}$.

1841, Sixth geological report to the Twenty-fourth General Assembly of the State of Tennessee: Nashville, $48 \mathrm{p}$.

-1843, Seventh geological report to the Twenty-fifth General Assembly of the State of Tennessee: Nashville, $45 \mathrm{p}$.

Twenhofel, W. H., 1915, Notes on black shale in the making: Am. Jour. Sci., 4th ser., v. 40, p. 272-280.

1932, Report of the Committee on Sedimentation, 19301932: Natl. Research Council Bull. 89, p. 5-19.

1939, Environments of origin of black shales : Am. Assoc. Petroleum Geologists Bull., v. 23, p. 1178-1198.

UIrich, E. O., 1911, Revision of the Paleozoic systems : Geol. Soc. America Bull., v. 22, p. 281-680.
CENTRAL TENNESSEE AND NEARBY AREAS

1912, The Chattanoogan series with special reference to the Ohio Shale problem: Am. Jour. Sci., 4th ser., v. 34, p. 157-183.

Ulrich, E. O., and Bassler, R. S., 1926, A classification of the toothlike fossils, conodonts, with descriptions of American Devonian and Middissippian species : U. S. Natl. Mus. Proc., จ. 68, art. 12, $63 \mathrm{p}$.

Ulrich, E. O., and Smith, W. S. T., 1905, The lead, zinc, and fluorspar deposits of western Kentucky: U. S. Geol. Survey Prof. Paper 36.

Washburne, C. W., 1937, Salt domes, meteor craters, and cryptovolcanic structures: Am. Assoc. Petroleum Geologists Bull., v. 21, p. 629-630.

Weaver, C. E., Wright, H. D., and Bates, T. F., 1952, Annual progress report on investigations of the mineralogy and petrography of uranium-bearing shales, July 1, 1951, to April 1, 1952 : U. S. Atomic Energy Commission NYO-3357.

Weller, J. M., and others, 1948, Correlation of the Mississippian formations of North America: Geol. Soc. America Bull., v. 59, p. 91-196.

Whitlatch, G. I., 1948, Carbsil Pigment Company: Tennessee State Planning Comm. Newsletter, p. 4, Nashville, Tenn. Also printed, in modified form, $b y$ W. H. S., 1948, Pay Dirt: Indus. Eng. Chemistry, v. 40, December, p. 22A-24A.

Wilmarth, M. G., 1938, Lexicon of geologic names of the United States (including Alaska) : U. S. Geol. Survey Bull. 896.

Wilson, C. W., Jr., 1935, Pre-Chattanooga development of the Nashville dome: Jour. Geology, v. 43, p. 449-481.

-1949, Pre-Chattanooga stratigraphy in central Tennessee: Tennessee Div. Geology Bull. 56.

[1951 ?], Geologic map of central Tennessee : Prelim. ed., Tennessee Div. Geology (one color; scale 1 inch $=1$ mile).

Wilson, C. W., Jr., and Born, K. E., 1936, The Flynn Creek disturbance, Jackson County, Tennessee: Jour. Geology, v. 44 , p. $815-835$.

Wilson, C. W., Jr., and Spain, E. L., Jr., 1936, Age of Mississippian "Ridgetop shale" of central Tennessee: Am. Assoc. Petroleum Geologists Bull., v. 20, p. 805-809.

Woolnough, W. G., 1937, Sedimentation in barred basins, and source rocks of oil: Am. Assoc. Petroleum Geologists Bull., จ. 21, p. 1101-1157.

Workman, L. E., and Gillette, Tracey, 1956, Subsurface stratigraphy of the Kinderhook series in Illinois: IIl. State Geol. Survey Rept. Inv. 189. 


\section{INDEX}

A

Acadian orogeny

Accumulation rate, sediment.

Acknowledgments ......... 4-5

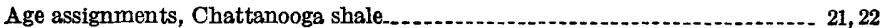

comparison with Campbell's..................................................... 22

Maury formation.

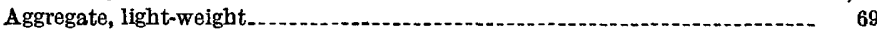

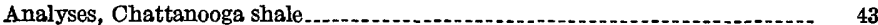

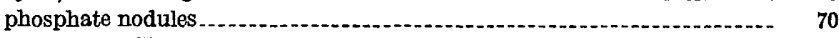
uranium in Chattanooga shale........................................ 74, 75, 76

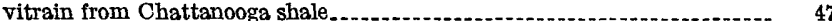

Appalachian Valley and Ridge, surface feature

Assays, oil shale.

Basal sandstone of Chattanooga shale, age... character and distribution
origin $\ldots \ldots$ petrography............... 44

relation to "blue phosphate" ...

relation to Hardin sandstone

Basal sandstone of Gassaway member

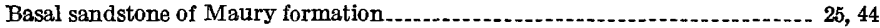

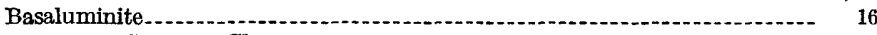

Bassler, R. S., age of Chattanooga shale

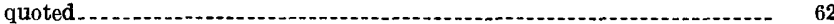

Batelle Memorial Institute, analyses by ....................................... 43

Bentonite, Dowelltown member

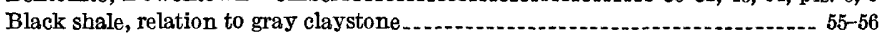

“Blue phosphate," composition.

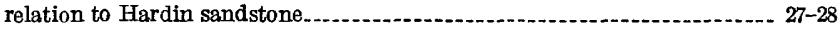
source of sediment

Bones, Chattanooga shale ......... 20-21, 44, 45, 47

Brachiopods, significance

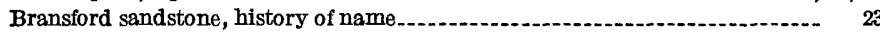
petrography.-.

source of sediment.

thickness

Breger, I. A., and Deul, Maurice, quoted... 73

\section{0}

Calcite....

44,48

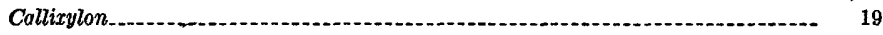

Cameron Hill, Chattanooga, Tenn, exposure of Chattanooga shale.......... 12

Campbell, Guy, age and nomenclature of Chattanooga shale............ 19, 22-23, 35 nomenclature of Maury formation

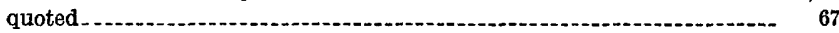

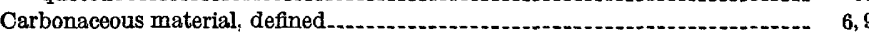
significance of preservation.

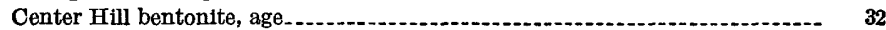
character and distribution.............. $4,30-32$, pls. 6 mica source of sediment

Chalcedony - . -

Chattanooga sea, environmental conditions

Chattanooga shale, age ....................... 16-21

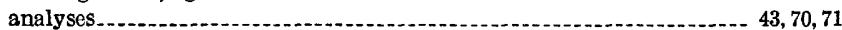
composition. distribution............................. 40, pls. 12, 14

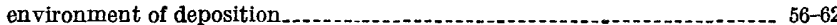

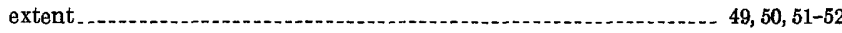
falls at Fall Creek Flynn Oreek cryptoexplosive feature................ 10-12, 30, 38, 55, 61, pls. 4,7 fossils........................................... 19-21, 35, 41-42, 62, 63, pl. history of name..................... 12-13 indications of deep-water origin indications of shallow-water origin paleogeography during Late Devonian time............................. 48-52
Chattanooga shale-Continued $\quad$ Page

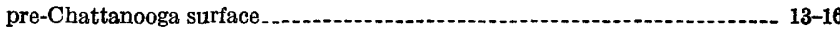

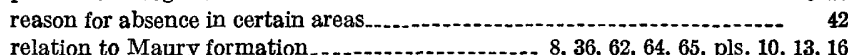
relation to Maury formation....................... 8, 36, 62, 64, 65, p]s. $10,13,1$ section $24,27,37,38,63,64$ sedimentation. . stratigraphy.................... 8, 21-40

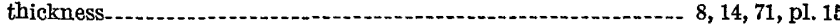

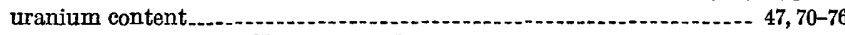

Chemical determinations, Chattanooga shale $\ldots \ldots \ldots . . . . . . . . . . . . . . . . .43,47,70,71$

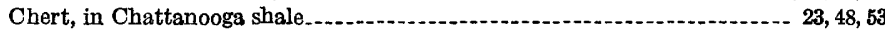

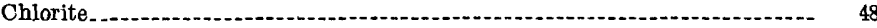

Clarke, J. M., quoted.......

Classifications, stratigraphic

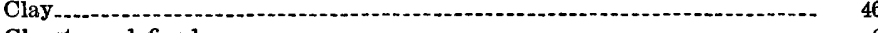

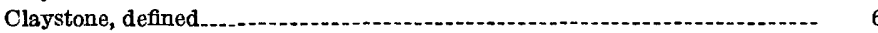

ia Dowelltown member.......

Coal. See Vitrain.

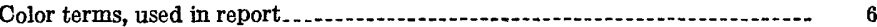

Compaction, sediment......... 10,55

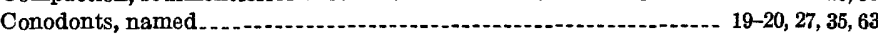

significance for age of shale_........................................ 16, 23,54

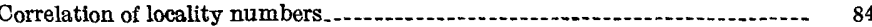

Cross Key, Tenn., section of Maury formation. 63,64

Cryptoexplosive structural features............................................. 9-12

Cumberland Plateau, surface feature ............................................ 6

\section{D}

Deep water, indications for origin of shale meaning of term

Definition of terms.

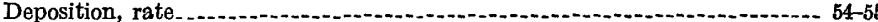

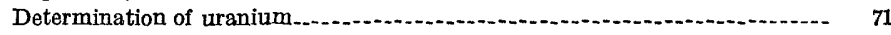

Deul, Maurice, and Breger, I. A., quoted..................................... 73

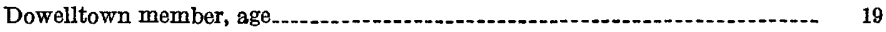
extent and thickness...................................... 28-29, 30, 33-34, pls. 7, 8

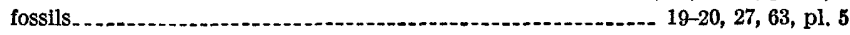

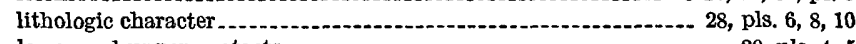

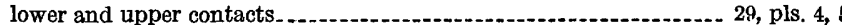

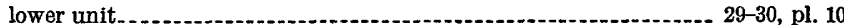

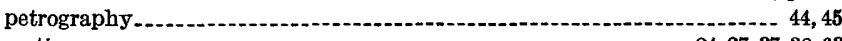
section

term used by Campbell

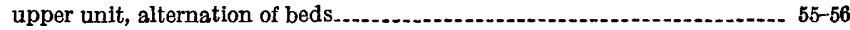
bentonite........... 30-32, pls. 6, 9 correlation of individual beds........................................ 32 extent and thickness.

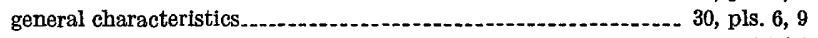

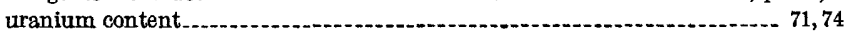
Drill holes, Chattanooga shale_................................ 4, $5,37,38,71,72,73,74$

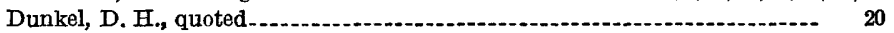
E

Eastern Highland Rim. See Highland Rim.

Economic geology, light-weight aggregate.................................... 69 oil shale

phosphate

pigment._........ 70

sulfuric acid. 70

uranium

Ellison, S. P., Jr, quoted............... 16

Environment of deposition, Chattanooga shale

Feldspar.

Fieldwork

Fine grain of shale, significance

Fish fossils. . . .

Flynn Creek cryptoexplosive area $\ldots \ldots \ldots \ldots . . . \ldots 10-12,25,30,55,61$, pl. 4 
Page

Foerste, A. F., quoted.-

Foerste, A. F., and Morse, W. C., age of Chattanooga shale.

Fort Payne chert, contact with Maury formation

Flynn Creek cryptoexplosive feature.................................... 10

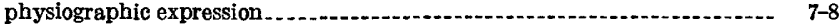

stratigraphy _........ 9, pl. 4

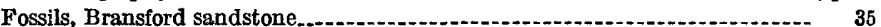

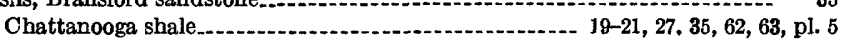

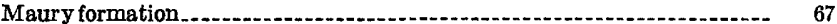

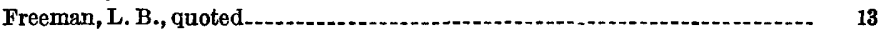

G

Galena. -

Gamma-ray log, Chattanooga shale and Maury formation

Gassaway member, age

basis for subdivision

extent and thickness

fossils

lithologic characteristics.................................... 34-35, pls 6, 9-11, 16

lower and upper contacts_....................................... 29, 36 , pls. 4,5

lower unit .

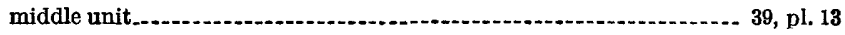

petrography ................. 44, 45

section $\ldots . . . \ldots \ldots \ldots$

term used by Campbell.

upper unit. . . . . .

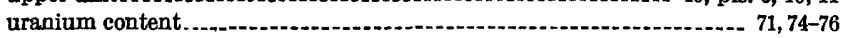

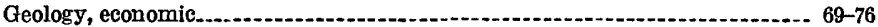

general.

Geosyncline, major tectonic element........ 48-51

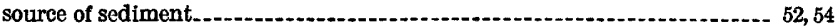

Germanium - 47-48

Girty, G. H., age of Chattanooga shale...

Glauconite, Chattanooga shale._._. 48

Maury formation.

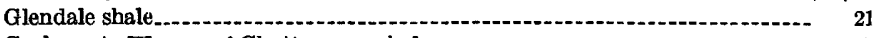

Grabau, A. W., age of Chattanooga shale... 17

\section{H}

Hard, E. H., quoted 58

Hardin sandstone member, age

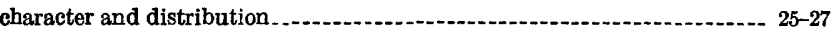

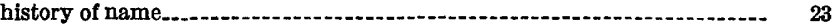

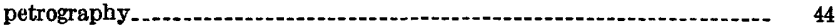

$$
\text { section. }
$$

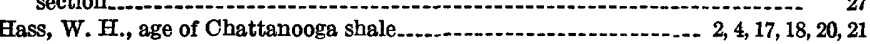
age of Maury formation......... 2,8,67

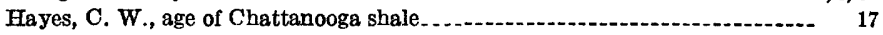
history of name of formation.......... 12, 13

Highland Rim, surface feature................................................... 6,

Historical summary, age of Chattanooga shale.............................. 16-21 environment of deposition of black shale............... 57-59

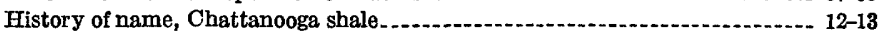

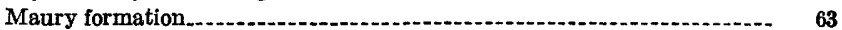

Hohenwald platform................ 41, 50, 53, pl. 15

Howell cryptoexplosive feature . . .

Huddle, J. W., age of Chattanooga shale.................................... 18

Illite.

$$
\mathbf{I}
$$

Interior platform, major tectonic element

Investigation methods.

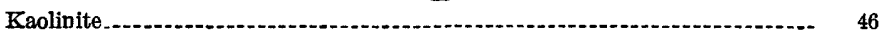

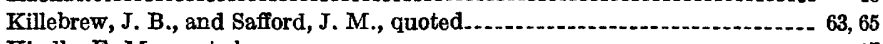

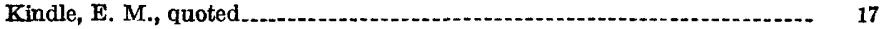

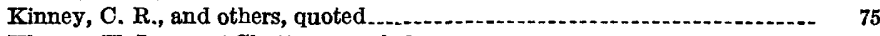

Klepser, H. J.. age of Chattanooga shale....... 18

$\mathbf{L}$

Lag-concentrates, significance.

Landmass, major tectonic element....... 51 source of sediment.

Lexington Basin, area of outcrops.................. 3

uranium content of shale

Lingula

Locality numbers...... 6,84

Locality register................................ 77-83,84

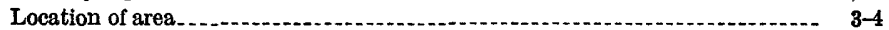

M Page

Marcasite

Mather, K. F., age of Chattanooga shale.................................. 17

Maury formation, age and classification.......................... 2, 8, 13, 21, 22, 42, 67

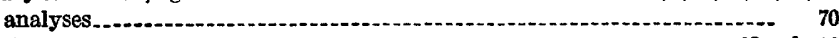
description. ............... 63, pl. 16

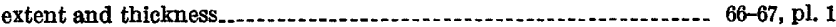

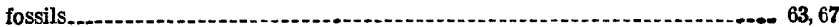

genetic significance.

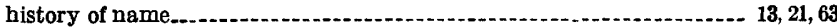

lower and upper contacts

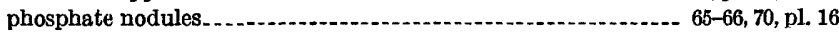

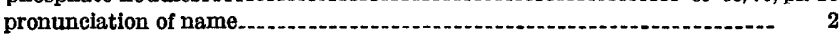

reasons for treating as separate formation ....................................... 62

relation to Chattanooga shale......... $32,62,64-65$

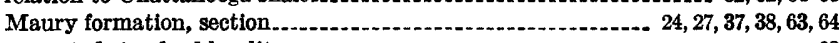

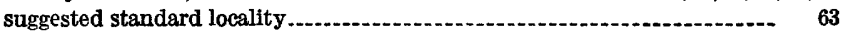

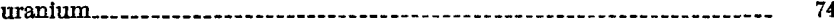

Measurements, linear, used in report_............................................ 6

Mica

Mineralogy, Center Hill bentonite.................. 30-31, 46

Chattanooga shale

phosphate nodules..... 47,66

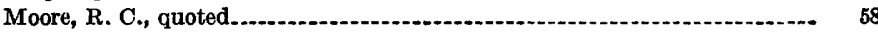

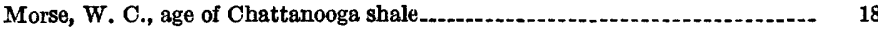

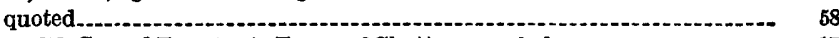

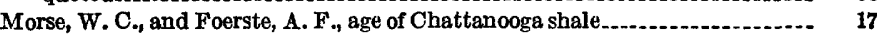

$\mathbf{N}$

Nashville Basin, area of outcrops

3, pl. 1

surface feature

New Albany shale, age

history of name

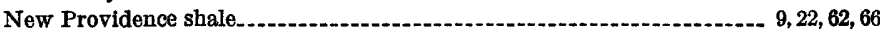

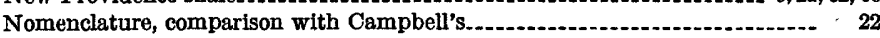

Northern Highland Rim. See Highland Rim.

Ohio shale, age

\section{0}

Oil shale

Outcrop localities.

$3,69-70$, pl. 17

$4,77-83,84$, pl. 1

Ozarkian land area.

$42,51,52,53$

Paleogeography, Late Devonian

48-52, pl. 14

Paleogeology, Late Devonian.

$8,13-14, \mathrm{pl}, 3$

Paleotectonic features, Late Devonian

$13-14, \mathrm{pl} .3$
$-48,50,51$

Pennsylvania State University studies

$23,45,46$

Petrographic determinations, Chattanooga shale

Phosphate, Chattanooga shale_........................................... 43, 47, 60. 70, 76

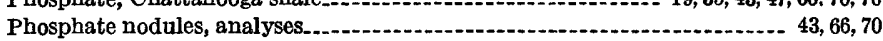
economic possibilities._._.

Maury formation

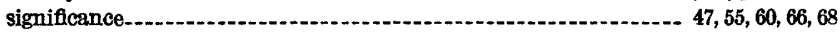
Physiography....... 6-8

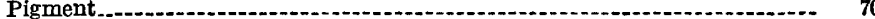

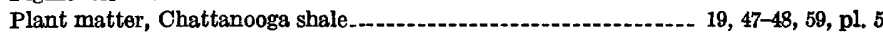

Pohl, E. R., age of Chattanooga shale

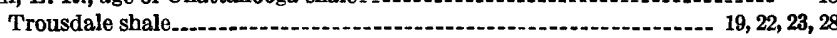

Pre-Chattanooga surface, general character........................ 13-14, pls, 3, sub-Chattanooga residuum................... 14-16, pl. 5

Purpose of study

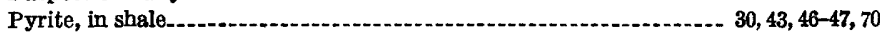
relation to uranium 73

Quartz.

Q

Radioactivity. See Uranium.

Radiolaria, Chattanooga shal

21

Register of localities

Residuum. See Sub-Chattanooga residuum.

Rich, J. L., quoted_.......... 57

Ridgetop shale

Ripple-marks, significance__-_._. 39, 59-60

Rock terms, defined.

Ross, Clarence S., quoted........... 31

Ruedemann, Rudolf, quoted. 
Page

Safford, J. M., age of Chattanooga shale history of name of Chattanooga shale.................................. 12, 13 history of name of Maury shale.

quoted

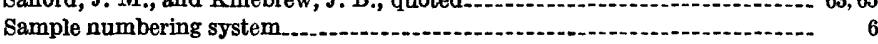

Samples, for uranium analysis..................................................... 70-71

Sampling methods....................... 4, 6, 70

Sandstone, defined.

Eavage, T. E., and Sutton, A. H., quoted _..... 18

Scope of study

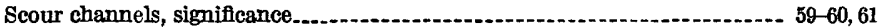

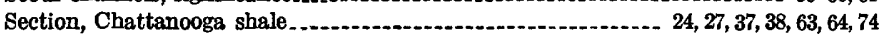
Flynn Creek cryptoexplosive feature

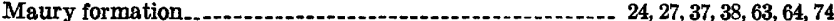

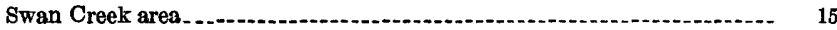

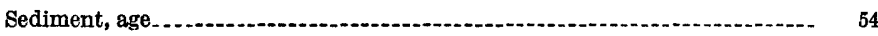
compaction

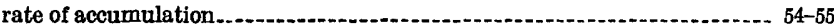

relation of black shale to gray claystone

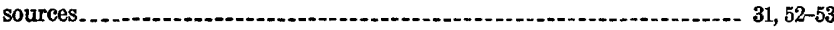

transportation.-........ 54

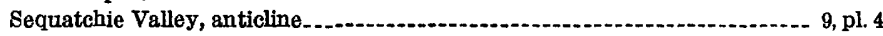

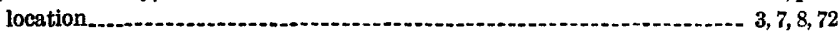

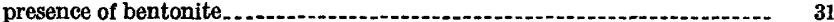

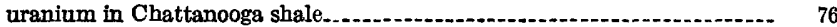

Shale, defined............. 56

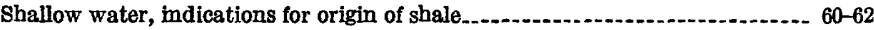

meaning of term

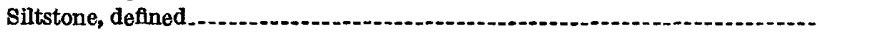

Southern Highland Rim. See Highland Rim.

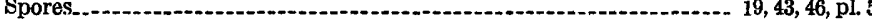

Standard locality and section, Chattanooga shale.............................. 23, 24

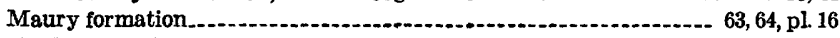

Standards, potentially exploitable ofl shale....................................... 69

Stockdale, P. B., age of Chattanooga shale quoted . .

Strahl, E. O., and others, cited..... 46

Stratigraphy, Chattanooga shale. .................................................... 21-40

regional

Structure of area

Sub-Chattanooga residuum....................................................... 14-16, pl. 5

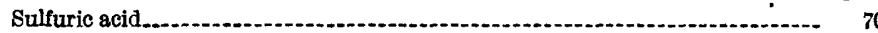

Sutton, A $B$, and Savage, T. E, quoted

18

Swan Creek area, "blue phosphate"........................................... 25, 28, 47 section

Swartz, J, H., age of Chattanooga shale

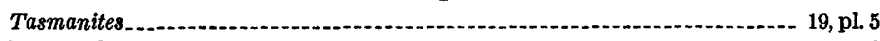

Terminology ..................... 5

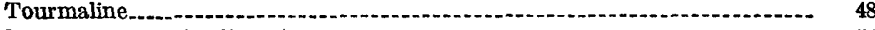

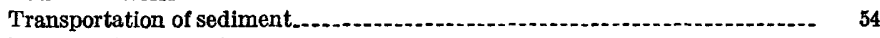

Trask, P. D., quoted....... 59

Troost, Gerard, history of name of formation . .

Trousdale shale.................................................................. 22-23, 48

Twenhofel, W. H., quoted..... 58

$\mathbf{U}$

Tlrich, E. O., age of Chattanooga shale

Uranium, determination. . . .

early studies.......................

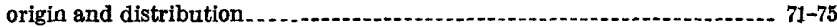

regional variations in content................................... 75-76, pls. 11, 12

relation of thickness of shale to content..................................... 71

sampling ................... 70-71

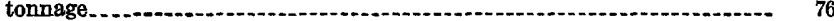

U.S. Bureau of Mines, analyses and assays.............................. 47, pl. 17 drilling

$\mathbf{v}$

"Varved" bed, middle unit of Gassaway member................ 39-40, 45, 55, pl. 13

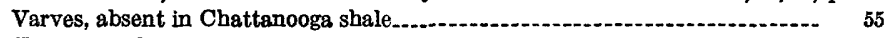
Vitrain, analyses. .

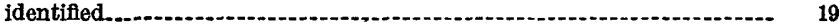

W

Water currents, transportation of sediments.

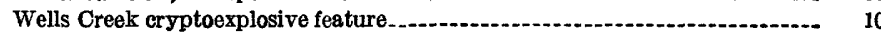

Western Highland Rim. See Highland Rim.

Whetstone Branch formation...............................................

Wind, transportation of sediment.

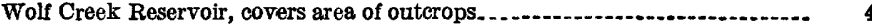

Z 
